\title{
Estudo da viabilidade de aplicação do polimero piezelétrico fluoreto de polivinilideno (PVDF) entre osso cortical e placa de osteossintese para estimulação de crescimento ósseo
}

\author{
André Luís Paschoal
}

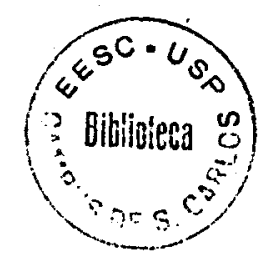

Tese apresentada à Área Interunidades em Ciência e Engenharia de Materiais, da Universidade de São Paulo, para obtenção do título de Doutor em Ciências e Engenharia de Materiais.

Orientadora: Prof ${ }^{\mathrm{a}}$. Dra ${ }^{\mathrm{a}}$. Lauralice de Campos Franceschini Canale 
Ficha catalográfica preparada pela Seção de Tratamento da Informação do Serviço de Biblioteca - EESC/USP

Paschoal, André Luís

Estudo da viabilidade de aplicação do polímero piezelétrico fluoreto de poliviniledeno (PVDF) entre osso cortical e placa de osteossíntese para estimulação de crescimento ósseo / André Luís Paschoal. -- São Carlos, 2003.

Tese (Doutorado) -- Escola de Engenharia de São Carlos/Instituto de Física de São Carlos/Instituto de Química de São Carlos-Universidade de São Paulo, 2003.

Área: Interunidades em Ciências de Engenharia de Materiais.

Orientador: Prof ${ }^{a}$. Dr ${ }^{a}$. Lauralice de Campos Franceschini Canale.

1. Biomateriais. 2. Biocompatibilidade. 3. PVDF. 4. Piezeletricidade. 5. Histomorfometria. 6. Osteossintese. I. Título. 
MEMBROS DA COMISSÃO JULGADORA DA TESE DE DOUTORADO DE ANDRÉ LUIS PASCHOAL APRESENTADA À ÁREA INTERUNIDADES CIÊNCIA E ENGENHARIA DE MATERIAIS, UNIVERSIDADE DE SÃo PAULO, EM 30-05-2003.

\section{COMISSÃO JULGADORA:}

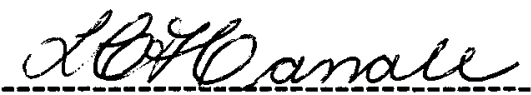

Profa. Dra. Lauralice de Campos F. Canale (Orientadora e Presidente) - EESC-USP
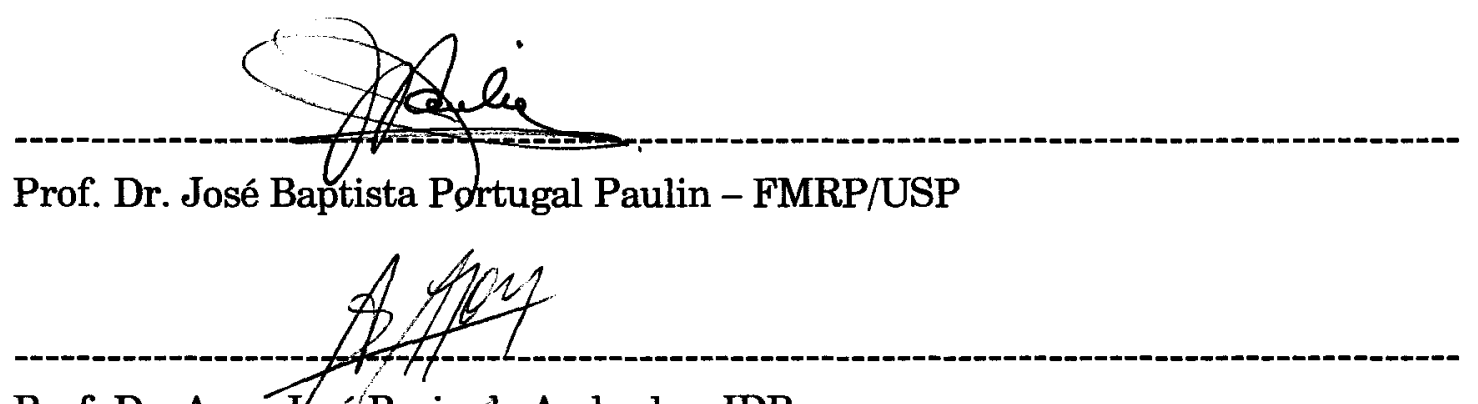

Prof. Dr. Aron J6sé Pazin de Andrade - IPP

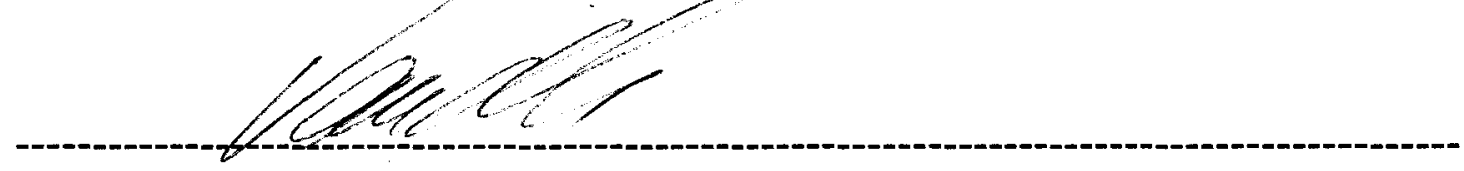

Prof. Dr. Vanderlei Salvador Bagnato - IFSC/USP

$$
\text { Gedes }
$$

Prof. Dr. Alberto Cliquet Júnior - EESC/USP 
".. a mente que se abre a uma nova ideia jamais voltará ao seu tamantio original..."

Albert Eisnstein 
Dedico este trabalho os meus pais, Jose e Aide, e a querida Angelica. que sempre me deram muito apoio $e$ carintio. 


\section{Agradecimentos}

Manifesto minfia gratidão a todas as pessoas que contribuiram direta ou indiretamente para a concretizaçäo deste trabafho. Cabe, nesse momento, os devidos agradecimentos como reconhecimento de suas valiosas colaboraföes. Em especial agradef̧o:

A Deus, pelas muitas vezes que pedi um pouco mais de força para conseguir chegar ao fim de mais uma etapa em minfia vida;

A Profa. Dra. Lauralice de Campos Franceschini Canale, minfia Orientadora, que hoje faz parte da minfia vida como uma grande amiga, pela dedicação e paciência em indicar os caminfros para atingir as metas necessárias à conclusão do presente trabalho.

Ao Prof. Dr. Orivaldo Lopes da Silva, que me confiou seu projeto de pesquisa, me orientou com um dom que poucos professores possui e se tomou um grande amigo;

A Fundação de Amparo a Pesquisa do Estado de São Paulo - FARESP - que tomou financeiramente possível a realização deste trabalfo;

Ao Programa Interunidades em Ciência e Engenfiaria de Materiais e em especial ao Departamento de Engenfaria de Materiais, Aeronáutica e Automobilística da Universidade de São Paulo por ceder meu canto de trabalfo como pós-graduando;

Ao Laboratório de Biomecânica do Instituto de Ortopedia e Traumatologia do Hospital das Clinicas da Faculdade de Medicina da Universidade de Säo Qaulo, por permitir a realizafáo de vánios experimentos na área biológica.

Ao Laboratóno de Fisiopatologia Renal da Faculdade de Medicina da Universidade de São Paulo, local de muita importância para o término desta tese.

Ao Prof. Dr. Artur de Jesus Motheo, (IFSC) pelo auxifio e pela paciência de acatar algumas de minhas idéias malucas;

Ao Dr. Raul Bolfiger Neto (IOT-HC-FMUSP), médico ortopedista, sempre solicito, que reafizou as cirurgias nos coelhos, além dos inúmeros conselhos sempre bem vindos;

A Profa. Dma Vanda Jorgetti, da Faculdade de Medicina da USP, uma pessoa incrivel e de um coraf̧ão enorme, que, do jeito dela, me ensinou sobre a técnica de fistomorfometria e estruturas ósseas;

A Médica Veterinária Angéfica Paula Grando, minha companheira de todas as horas, a quem devo toda a parte de acompanfiamento para realização das cinurgias e manutenfão dos coelfos, além da incrivel paciência de tantos anos.

Ao Engenfieiro Tomaz Puga Leivas (IOT-HC-FMUSP), pelas várias e incansáveis reuniôes para tratar de assuntos relacionados a esse trabaltio;

Ao Especialista em Biomecânica César Augusto Martins Pereira (IOT-HCC-FMUSP), um grande amigo e uma pessoa como poucas, sempre disposto a ajudar e para quem nada é imposstuel;

A Tecnóloga em Saúde, Márcia Salgado Costa Amaral, do IOT; que sempre auxifiou no que precisei.

Aos Técnicos de Biotério Gustavo e Kauê, a quem devo muita gratidão pelo trabafho que tiveram em cuidar dos animais tanto antes como após as cinurgias; 
$\mathcal{A}$ Bióloga Marifisa de Líria Vieria, que me ensinou muito no tempo em que estive no IOT-HCFMUSP;

Ao Engenheiro José Tadeu Leme, da Empresa ENGIMPLANN, que acreditou na realização deste trabalfo e fomeceu as placas e os dispositivos de fixacão para a realizacão dos implantes;

A Enfermeira Odália Spadoni do Centro de Material Esterifizado do (IOT-HC-FMUSP), a quem devo tanta perturbação pelas inúmeras vezes que atrapalhava seu servico para pedir que esterifizasse meus materiais e dispositivos;

Prof. Dr. José Alberto Giacometti e Prof Dr. Célio Wisniewski, do Grupo de Polimeros Bemfiard Gross do Instituto de Física de São Cartos, pela doaf̧a e a colaboração na polanizafão das amostras de polimero.

Ao Instituto Adolfo Lutz pela realização do teste de citotoxicidade;

Aos amigos funcionánios do Departamento de Materiais Efiete, Ana, Regina, Lúcia, Dona Elza; Eliezer, Jođo, Pedro, Silvano e Alberto;

A Rozidete, do Laboratório de Fisiopatologia Renal, que, muitas vezes sem poder, arranjava um tempinfo para aprontar minfas lâminas com amostras ósseas para a fistomorfometria;

Aos amigos Marco Ferrari, Fábio Vergifi, Femando Vicentini, Marcelo Barbosa, Eduardo Miola e Rosamel Riofano pelo companheirismo, e por me estenderem a mão na fora em que realmente precisei.

$\mathcal{A}$ Dra. Elizete Lopes Guifherme, do Instituto de Anatomia Patológica de São Carlos, que com muita boa vontade, realizou os laudos morfológicos das lâminas fistológicas.

Ao Biólogo Nelson Júnior, do Departamento de Bioengenfiria da EESC-USP, pela grande ajuda nas montagens das lâminas de fistologia.

Aos companfeiros pós-graduandos e aos professores do SMM.

$\mathcal{E}$ finalmente, mas não menos importante, aos coelhos e camundongos que cederam suas vidas para a realização desta pesquisa. 


\section{Sumário}

Cista de Figuras......................................................................................... i

Lista de Tabelas............................................................................................................ viui

Cista de A6reviaturas e Siglas.......................................................................... xi

Resumo................................................................................................................... xiii

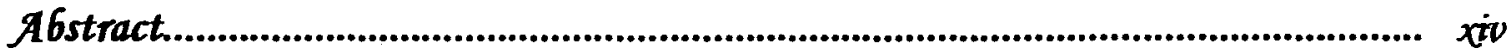

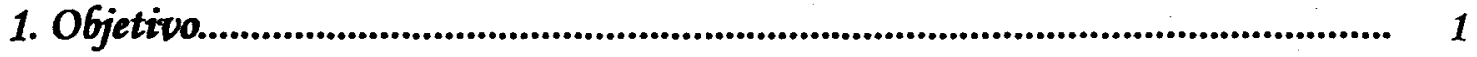

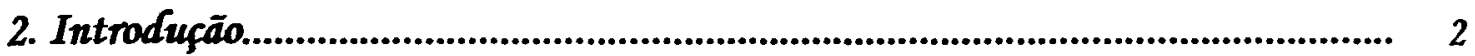

3. Revisão Bibfrográfica............................................................................ 3

3.1. Biomateriais.............................................................................................................................. 3

3.2. Fluoreto de polivinilideno (PVDF)................................................................................ 5

3.2.1. Aplicações biomédicas........................................................................................................ 8

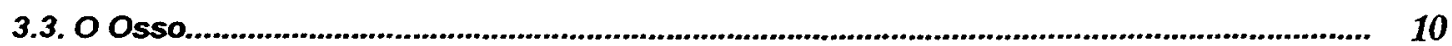

3.3.1. Estimulação elétrica do crescimento ósseo.................................................................. 14

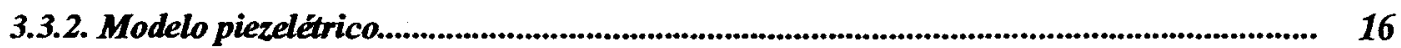

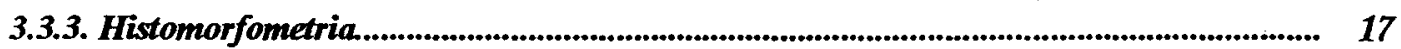

3.4. Ensajos de Biocompatibilidade: Testes de Citotoxicidade, Sensibilidade Intracutânea e Toxicidade Sistêmica..................................................................................................... 19

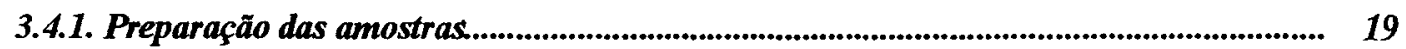

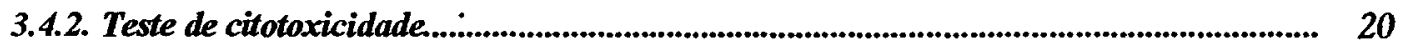

3.4.3. Teste de sensibilidade intracutânea.................................................................................. 21

3.4.4. Teste de toxicidade sistêmica................................................................................... 22

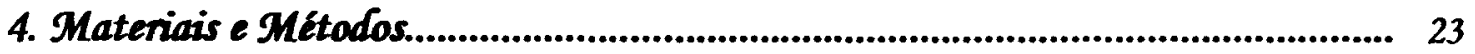

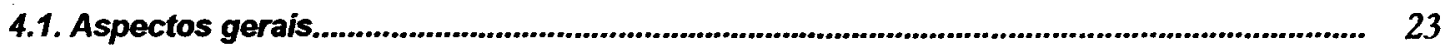

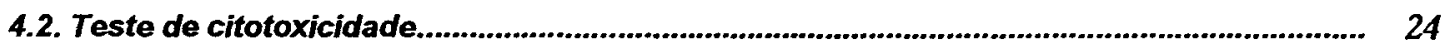

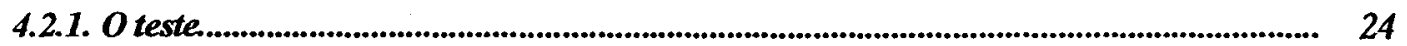

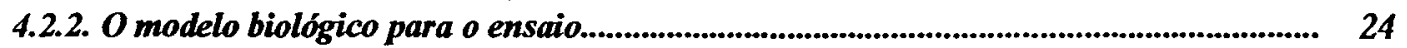

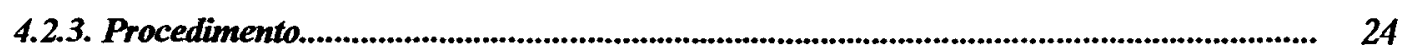

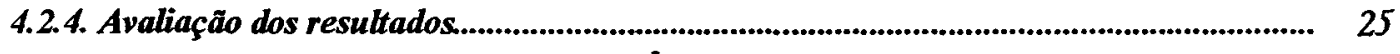

4.3. Preparo do veiculo de extração: Testes de Sensibilidade Intracutânea e Toxicidade Sistêmica.

4.3.1. Veículos de extração ou solventes........................................................................ 25 


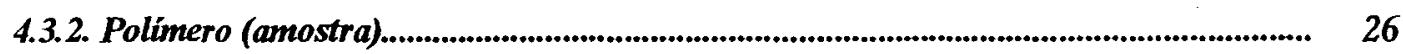

4.3.3. Preparação dos extratos e controles................................................................... 26

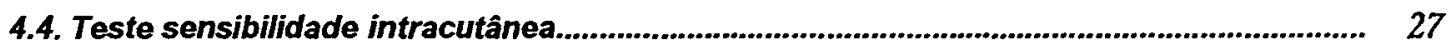

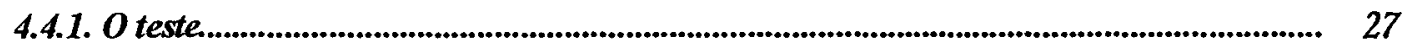

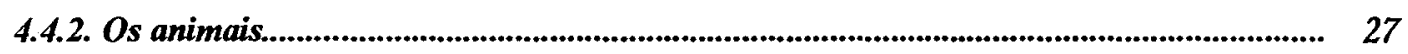

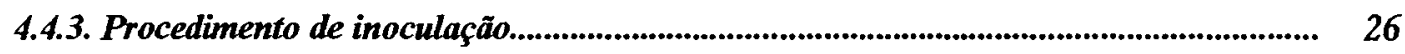

4.4.4. Observação dos animais: formação de edemas e eritemas................................................ 28

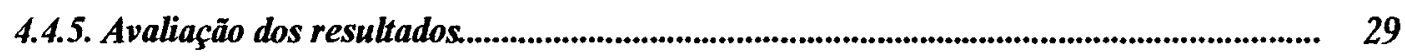

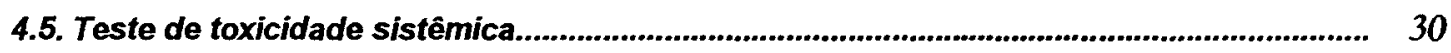

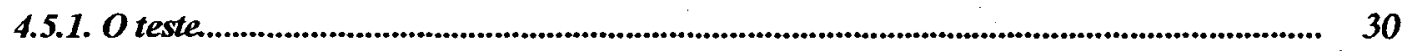

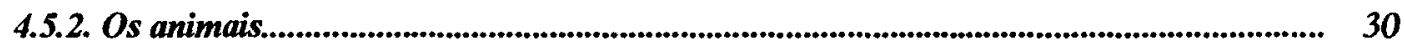

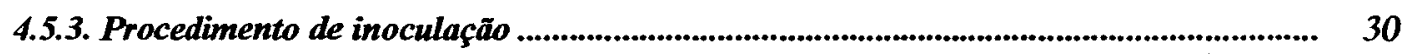

4.5.4. Observação das reações adversas dos animais: coleta de dados.................................... 31

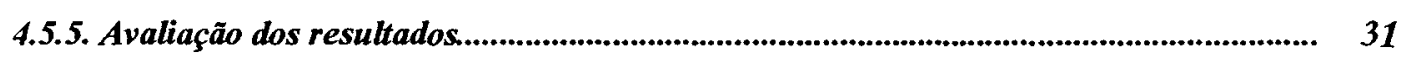

4.6. Cirurgia de implante do PVDF em tíbias de coelhos..................................................... 32

4.6.1. Os animais e os procedimentos pré-cirúrgicos............................................................ 32

4.6.2. Material implantado e equipamentos extracaixa cirúrgica....................................... 32

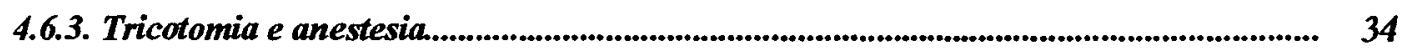

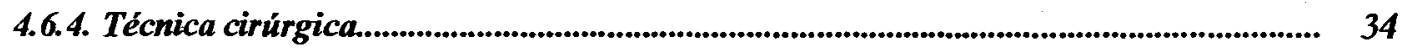

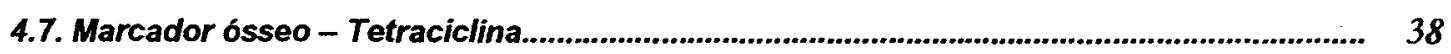

4.8: Protocolo de exercício físico e esteira............................................................................... 39

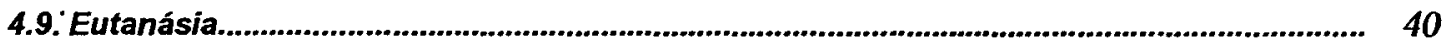

4.10. Preparação das amostras para contagem histomorfométrica............................................. 40

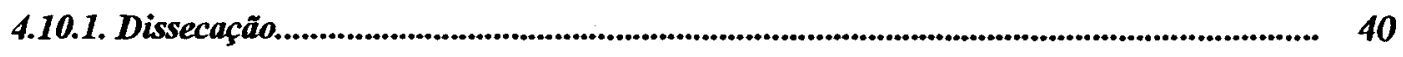

4.11. Parâmetros para medição - Histomorfometria................................................................ 41

4.11.1. Coleta de dados histomorfométricos.......................................................................... 44

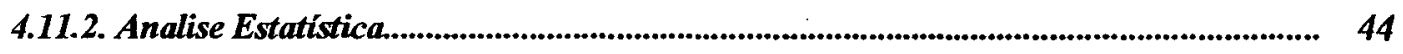

4.12. Análise morfológica - Histologia....................................................................... 45

5. Resultados e Discussōes.................................................................................... 46

5.1. Teste de esterilização........................................................................................................... 46

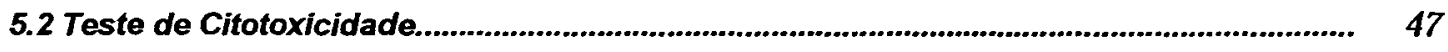

5.3 Teste Sensibilidade Intracutânea............................................................................... 48

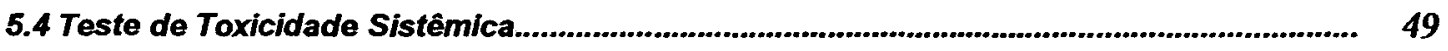

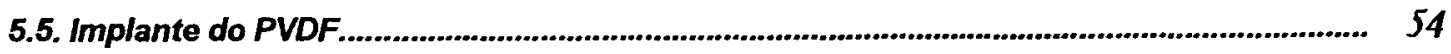


5.6. Análise estatística dos dados histomorfométricos................................................. 56

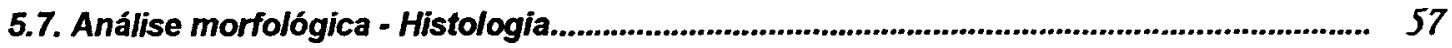

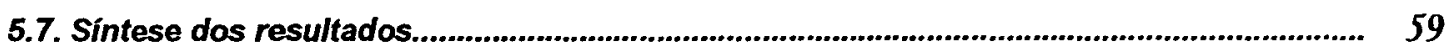

6. Conclusöes............................................................................................................ 63

7. Sugestões para Tra6afhos Futuros........................................................................... 64

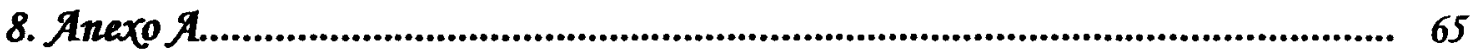

8.1. Aprovação do Projeto de Trabalho pela Comissão de Ética para Análise de Projetos de Pesquisa do Hospital das Clínicas da Faculdade de Medicina da Universidade de Sāo Paulo.

9. Anexo B.

9.1. Laudo do Teste de Citotoxicidade emitido pelo Adolfo Lutz.

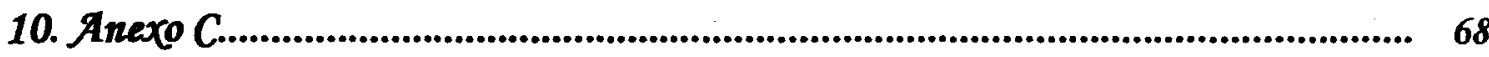

10.1. Planilha de Anotações - Sensibilidade Intracutânea.................................................... 68

10.2. Exemplo do procedimento do cálculo para obtenção da Contagem de Irritação Primária e Índice de Irritação Primária para o Teste se Sensibilidade Intracutânea com animais hipotéticos.

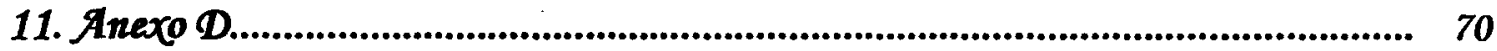

10.1. Planilhas de Anotaçōes - Toxicidade Sistêmica............................................................ 70

12. Anexo $E$.

12.1. Planilha de acompanhamento dos coelhos........................................................... 71

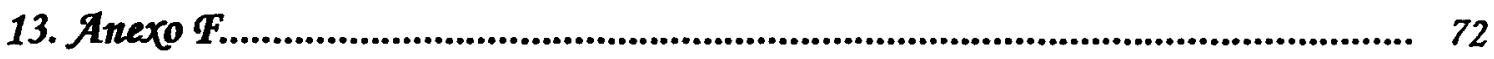

13.1. Adaptação de esteira ergométrica para os exercícios fisicos dos coelhos.................... 72

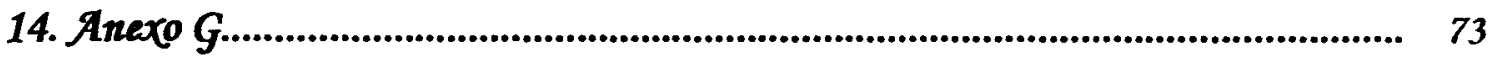

14.1. Princípios Éticos na Experimentação Animal (Colégio Brasileiro de Experimentação Animal - COBEA).

15. Anexo $\mathcal{H}$...

15.1. Etapas de dissecação, emblocamento em resina acrilica e confecção das lâminas para leitura histomorfométrica.

15.2. Inclusāo das amostras teciduaís ósseas calcificadas.

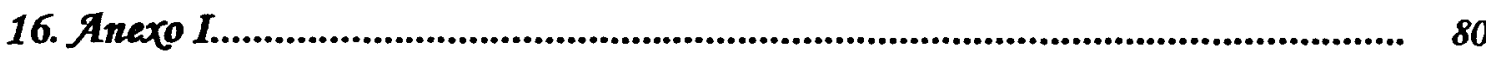

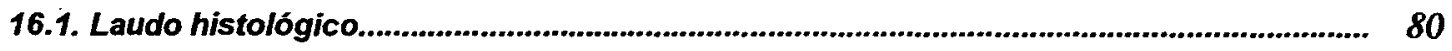

17. Refercucias bibliográficas.............................................................. 81

17.1. Bibliografia consultada e nāo referencia da no texto....................................................... 88 


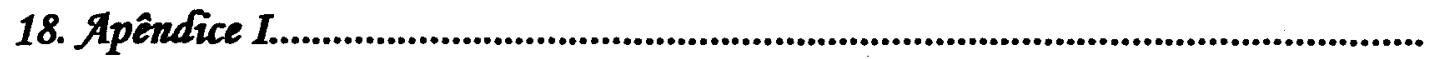

18.1. Tabelas com os dados observados de formação de edemas e eritemas no teste de Sensibilidade Intracutânea: Obtenção da Contagem de Irritação

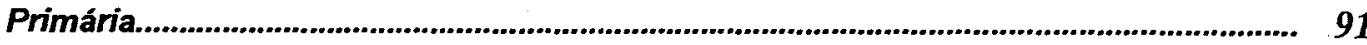

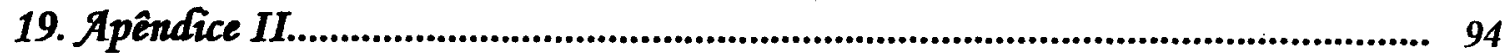

19.1. Tabelas e gráficos com os dados histomorfométricos e estatísticos.............................. 94 


\section{Lista de Figuras}

Figura 3.1 - Esquema da classificação dos biomateriais.

(adaptado [2,3]).

Figura 3.2 - Esquema dos modelos espaciais do PVDF em três conformações concluídas de análises estruturais de cristais. $\mathbf{O}$ diagrama indica os átomos de carbono e de flúor visualizados paralelamente ao eixo da cadeia. Os átomos de hidrogênio foram omitidos nos esquemas a,b e c. As imagens c e d mostram a rotação da forma $\beta$ do PVDF molecular, que ocorre quando está sob influência de um campo elétrico (PVDF em um plano "zig-zag"). Isto indica que os átomos de flúor estão alinhados a um campo elétrico. $\mathrm{P}=$ polarização. $\mathrm{O}$ eixo $\mathrm{Y}$ é paralelo a cadeia; $\mathrm{Z}$ é o eixo polar (adaptado ${ }^{[6,9]}$ ).

Figura 3.3 - Osso cortical e osso trabecular de fềmur humano. (foto obtida de peça anatômica do Departamento de Bioengenharia da USP São Carlos).

Figura 3.4 - Esquema de alguns aspectos do papel do osteoclasto na reabsorção. (adaptado $\left.{ }^{[27]}\right)$.

Figura 3.5 - Foto de cortical de tíbia de coelho não descalcificada: a) osteoclasto; b) osteoblastos; c) osso mineralizado; d) osteócito; e) osteóide (matriz não mineralizada). Corante Azula de Toluidina.

Figura 3.6 - Atividade da unidade de remodelação óssea (BRU) em osso cortical em vista longitudinal e subseqüente vista transversal. a) osteoclastos escavam um túnel, criando um "cone de abertura". b) Em seguida, novo osso é formado na área do "cone de fechamento" c) conduzindo a criação de uma nova unidade estrutural óssea (BSU - bone structural unit), isto é, osteon cortical ou sistema haversiano. (adaptado ${ }^{[29]}$ ).

Figura 3.7 - Esquema da atividade da unidade de remodelamento ósseo (BRU) em osso trabecular em vista longitudinal e subseqüente vista transversal. a BRU do osso trabecular pode ser comparada a uma BRU cortical cortada ao meio. Cinco diferentes fases podem ser diferenciadas: 1) reabsorção osteoclástica; 2) reabsorção mononuclear; 3) migração proosteoblástica e diferenciação para osteoblastos; 4) formação de matriz osteoblástica (osteóide); 5) mineralização, 6) $O$ produto final do remodelamento é a unidade óssea estrutural (BSU) trabecular, ou seja, osteon trabecular, recoberto por células. ${ }^{[2]}$. 
Figura 3.8 - Frente de mineralização óssea marcada com tetraciclina. Repare a dupla marcação (setas brancas), local onde as medidas histomorfométricas são realizadas. (com autorização da Dra Vanda Jorgetti - Laboratório de Fisiopatologia Renal FMUSP).

Figura 4.1 - Tricotomia na região dorsal do coelho.

Figura 4.2 - Aplicação dos extratos e controles polares para teste de sensibilidade intracutânea. a) Demonstração dos quadrantes e visualização após aplicação intracutânea (seta); b) Locais de aplicação.

Figura 4.3. - a) Tricotomia na região abdominal do camundongo; b) Aplicação de extrato/veículo de extração na região abdominal (intraperitonial) do camundongo.

Figura 4.4 - Filme de PVDF polarizado. a) antes de ser submetido ao processo de esterilização por óxido de etileno; b) acondicionado em embalagem dupla e esterilizado (dentro da marcação quadrada).

Figura 4.5 - Placa de osteointegração bucomaxilofacial em titânio comercialmente puro e parafusos em Ti-6Al-4V utilizados para fixação do PVDF junto à tíbia do coelho. (Fornecidos pela empresa ENGIMPLAN Ind. e Com. Ltda). a) antes de ser submetido ao processo de esterilização por óxido de etileno; b) acondicionado em embalagem dupla e esterilizado.

Figura 4.6 - Equipamentos: a)Chave específica para os parafusos da placa bucomaxilofacial. (Fornecida pela empresa ENGIMPLAN Ind. e Com. Ltda) e b) guia para as brocas.

Figura 4.7 - Descrição da técnica cirúrgica: a) animal anestesiado e tricotomia bilateral das tíbias pronta; b) preparação da mesa cirúrgica;.

Figura 4.8 - Descrição da técnica cirúrgica: a) anti-sepsia pré-operatória; b) inserção;....

Figura 4.9 - Descrição da técnica cirúrgica: a) exposição da tíbia; b) utilização do guia para a realização das perfurações, na camada cortical da tíbia para fixação da placa e do polímero (broca $1,5 \mathrm{~mm}$ de diâmetro);

Figura 4.10 - Descrição da técnica cirúrgica: a) realização dos furos maiores (broca de 2,5 mm de diâmetro), utilizando o guia, que servirão de locais de análise de crescimento ósseo; b) demonstração dos furos para os parafusos da placa (seta azul) e os furos, para análise de crescimento ósseo (seta branca).

Figura 4.11 - Descrição da técnica cirúrgica: a) detalhe do polímero implantado com os furos para passagem dos parafusos; b) fixação do polímero (entre a tíbia e a placa) utilizando chave especial; 
Figura 4.12 - Descrição da técnica cirúrgica: a) placa e polímero fixado; b) sutura finalizada.

Figura 4.13 - Caixa de contenção (LIM-41 - IOT - HC - FMUSP).

Figura 4.14 - Equipamento para medidas histomorfométricas:

a) microcomputador/monitor; b) microscópio; c) câmera; d) mouse (cursor) e placa digitalizadora com campo de mensuração (integrado ao software).

Figura 4.15 - Detalhe da imagem digitalizada da lesão óssea provocada nas tíbias.

Note que foram necessários nove campos para formar a imagem (cada campo corresponde a um dos quadrados da figura).

Figura 4.16 - Placa digitalizadora com a área de medição (quadrado negro ao centro), do mouse/cursor (sobre o quadrado) e da câmera (seta) que sobrepõe as imagens da lâmina e do campo.

Figura 4.17 - Imagens demonstrando a montagem digitalizada da lesão da tíbia: a) detalhe do campo com imagem digitalizada; b) Imagens da lesão na tíbia digitalizada, montada com nove campos. Abaixo, detalhe da área de medição (quadrado cinza), com a calibração correspondente.

Figura 5.1 - Gráficos demonstrando a perda da polarização do PVDF devido aos processos de esterilização por óxido de etileno (EtO) e Radiação por cobalto 60. a) em coeficiente piroelétrico $\left.\left(\mu \mathrm{Cm}^{-2} \mathrm{~K}^{-1}\right) ; \mathrm{b}\right)$ em porcentagem.

Figura 5.2 - Gráfico demonstrativo de perda e recuperação de peso dos camundongos submetidos ao ensaio de Toxicidade Sistêmica com extratos e controles polares.....

Figura 5.3 - Gráfico demonstrativo de perda e recuperação de peso dos camundongos submetidos ao ensaio de Toxicidade Sistêmica com extratos e controles intermediários.

Figura 5.4 - Gráfico demonstrativo de perda e recuperação de peso dos camundongos submetidos ao ensaio de Toxicidade Sistêmica com extratos e controles nãopolares.

Figura 5.5 - Gráfico da observação comportamental em camundongos do ensaio de Toxicidade Sistêmica a 0 horas: Animais inoculados com Controle Intermediário, Extrato e Controle Não-Polar apresentaram reações leves.

Figura 5.6 - Gráfico da observação comportamental em camundongos do ensaio de Toxicidade Sistêmica a 24 horas: Apenas alguns animais inoculados com Extrato e Controle Não-Polar apresentaram reações leves.. 
Figura 5.7 - Gráfico da observação comportamental em camundongos do ensaio de Toxicidade Sistêmica a 48 e 72 horas: Nesses tempos, todos os animais inoculados com todos os extratos e controles voltaram a normalidade, demonstrando e ser o PVDF atóxico neste tipo de teste.

Figura 5.8 - Gráfico demonstrativo de recuperação ao estado de normalidade comportamental dos camundongos submetidos ao ensaio de Toxicidade Sistêmica após 72 horas.

Figura 5.9 - Tíbias de coelho, com e sem o PVDF, após trinta dias da data do implante: a) Tíbia direita com polímero e b) tíbia esquerda, controle, sem polímero. (coelho sem exercício fisico)

Figura 5.10 - Tíbias de coelho, com e sem o PVDF, após trinta dias da data do implante: a) Tíbia esquerda com polímero e b) tíbia direita, controle, sem polímero. (coelho sem exercício físico).

Figura 5.11 - Tíbias de coelho, com e sem o PVDF, após trinta dias da data do implante: a)Tíbia esquerda com polímero e b) tíbia direita, controle, sem polímero. (coelho com exercício físico).

Figura 5.12 - Tíbias com e sem o PVDF de alguns coelhos após trinta dias da data do implante: a) Tíbia direita com polímero e b) tíbia esquerda, controle, sem polímero. (coelho com exercicio fisico).

Figura 5.13 - Regeneração óssea: a) osso cortical; b) linha delimitante entre osso integro e início da regeneração óssea na lesão (provocada com broca de $2,5 \mathrm{~mm}$ de diâmetro); c) osso neoformado; d) medula. e células fibrosas. Tecido ósseo leporino. Azul de toluidina. Calcificado. X40.

Figura 13.1 - a) A polia "a" era a que estava anteriormente na esteira; a polia "b" é a atual. b) Polia redimensionada adaptada à esteira.

Figura 13.2 - a) Esteira ergométrica adaptada para realização de exercício físico em coelhos implantados com PVDF. b) Coelho sendo exercitado

Figura 15.1 - Tíbias de coelho implantadas: a) Tíbia direita sem PVDF, b) Tíbia esquerda com PVDF (note a diferença de crescimento do periósteo sobre a placa).

Figura 15.2 - Tíbias de coelho dissecada: a) Tíbia já sem a placa e com as marcações imaginárias dos locais de corte; b) Tíbia sendo cortada com disco de aço para retirada da amostra de osso. A agulha no canto superior da figura é para refrigerar o locar de corte com soro fisiológico.

Figura 15.3 - Equipamento utilizado para o corte das amostras ósseas: a) detalhe do disco de aço; b) Disco de aço acoplado a microretífica 
Figura 15.4 - Peça a ser analisada retirada da tíbia, a) detalhe da peça; b) peça colocada em etanol $70 \%$ para o início do processo de desidratação.

Figura 15.5 - Montagem de um bloco histológico para corte em micrótomo. a) peça histológica embutida em resina dentro e fora do molde de vidro, b) acabamento para a confecção do bloco

Figura 15.6 - Montagem de um bloco histológico para corte em micrótomo. a) Formato do bloco para ser colocado nos equipamentos de corte histológico, b) Micrótomo Leica, com detalhe o bloco . (aparelho do Laboratório de Fisiopatologia Renal - LIM 16 - FMUSP)

Figura 19.1 - Gráfico dos valores médios para área óssea total. (c/PVDF-s/ex. - com PVDF, sem exercício); (s/PVDF-s/ex. - sem PVDF, sem exercício); (c/PVDFc/ex. - com PVDF, com exercício);(s/PVDF-c/ex. - sem PVDF, com exercício); (c/PVDF-total. - todos os dados com PVDF); (s/PVDF total. - todos os dados sem PVDF).

Figura 19.2 - Gráfico dos valores médios para volume de osso total. (c/PVDF-s/ex. com PVDF, sem exercício); (s/PVDF-s/ex. - sem PVDF, sem exercício); (c/PVDF-c/ex. - com PVDF, com exercício);(s/PVDF-c/ex. - sem PVDF, com exercício); (c/PVDF-total. - todos os dados com PVDF); (s/PVDF total. - todos os dados sem PVDF).

Figura 19.3 - Gráfico dos valores médios para área de osso mineralizado total. (c/PVDF-s/ex. - com PVDF, sem exercício); (s/PVDF-s/ex. - sem PVDF, sem exercício); (c/PVDF-c/ex. - com PVDF, com exercício);(s/PVDF-c/ex. - sem PVDF, com exercício); (c/PVDF-total. - todos os dados com PVDF); (s/PVDF total. - todos os dados sem PVDF).

Figura 19.4 - Gráfico dos valores médios para área medular. (c/PVDF-s/ex. - com PVDF, sem exercício); (s/PVDF-s/ex. - sem PVDF, sem exercício); (c/PVDFc/ex. - com PVDF, com exercício);(s/PVDF-c/ex. - sem PVDF, com exercício); (c/PVDF-total. - todos os dados com PVDF); (s/PVDF total. - todos os dados sem PVDF).

Figura 19.5 - Gráfico dos valores médios para área osteóide. (c/PVDF-s/ex. - com PVDF, sem exercício); (s/PVDF-s/ex. - sem PVDF, sem exercicio); (c/PVDFc/ex. - com PVDF, com exercício);(s/PVDF-c/ex. - sem PVDF, com exercício); (c/PVDF-total. - todos os dados com PVDF); (s/PVDF total. - todos os dados sem PVDF). 
Figura 19.6 - Gráfico dos valores médios para espessura osteóide. (c/PVDF-s/ex. com PVDF, sem exercício); (s/PVDF-s/ex. - sem PVDF, sem exercício); (c/PVDF-c/ex. - com PVDF, com exercício);(s/PVDF-c/ex. - sem PVDF, com exercício); (c/PVDF-total. - todos os dados com PVDF); (s/PVDF total. - todos os dados sem PVDF).

Figura 19.7 - Gráfico dos valores médios para superficie osteóide. (c/PVDF-s/ex. com PVDF, sem exercício); (s/PVDF-s/ex. - sem PVDF, sem exercício); (c/PVDF-c/ex. - com PVDF, com exercício);(s/PVDF-c/ex. - sem PVDF, com exercício); (c/PVDF-total. - todos os dados com PVDF); (s/PVDF total. - todos os dados sem PVDF).

Figura 19.8 - Gráfico dos valores médios para volume osteóide. (c/PVDF-s/ex. - com PVDF, sem exercício); (s/PVDF-s/ex. - sem PVDF, sem exercício); (c/PVDFc/ex. - com PVDF, com exercício);(s/PVDF-c/ex. - sem PVDF, com exercício); (c/PVDF-total. - todos os dados com PVDF); (s/PVDF total. - todos os dados sem PVDF)

Figura 19.9 - Gráfico dos valores médios para superficie osteoblástica. (c/PVDF-s/ex. - com PVDF, sem exercício); (s/PVDF-s/ex. - sem PVDF, sem exercício); (c/PVDF-c/ex. - com PVDF, com exercício);(s/PVDF-c/ex. - sem PVDF, com exercício); (c/PVDF-total. - todos os dados com PVDF); (s/PVDF total. - todos os dados sem PVDF).

Figura 19.10 - Gráfico dos valores médios para superficie osteoclástica. (c/PVDFs/ex. - com PVDF, sem exercício); (s/PVDF-s/ex. - sem PVDF, sem exercício); (c/PVDF-c/ex. - com PVDF, com exercício);(s/PVDF-c/ex. - sem PVDF, com exercício); (c/PVDF-total. - todos os dados com PVDF); (s/PVDF total. - todos os dados sem PVDF).

Figura 19.11 - Gráfico dos valores médios para superficie de reabsorção. (c/PVDFs/ex. - com PVDF, sem exercício); (s/PVDF-s/ex. - sem PVDF, sem exercício); (c/PVDF-c/ex. - com PVDF, com exercício);(s/PVDF-c/ex. - sem PVDF, com exercício); (c/PVDF-total. - todos os dados com PVDF); (s/PVDF total. - todos os dados sem PVDF).

Figura 19.12 - Gráfico dos valores médios para área trabecular. (c/PVDF-s/ex. - com PVDF, sem exercício); (s/PVDF-s/ex. - sem PVDF, sem exercício); (c/PVDFc/ex. - com PVDF, com exercício); (s/PVDF-c/ex. - sem PVDF, com exercício); (c/PVDF-total. - todos os dados com PVDF); (s/PVDF total. - todos os dados sem PVDF). 
Figura 19.13 - Gráfico dos valores médios para espessura trabecular. (c/PVDF-s/ex. com PVDF, sem exercício); (s/PVDF-s/ex. - sem PVDF, sem exercício); (c/PVDF-c/ex. - com PVDF, com exercício); (s/PVDF-c/ex. - sem PVDF, com exercício); (c/PVDF-total. - todos os dados com PVDF); (s/PVDF total. - todos os dados sem PVDF).

Figura 19.14 - Gráfico dos valores médios para número trabecular. (c/PVDF-s/ex. com PVDF, sem exercício); (s/PVDF-s/ex. - sem PVDF, sem exercício); (c/PVDF-c/ex. - com PVDF, com exercício); (s/PVDF-c/ex. - sem PVDF, com exercício); (c/PVDF-total. - todos os dados com PVDF); (s/PVDF total. - todos os dados sem PVDF).

Figura 19.15 - Gráfico dos valores médios para separação trabecular. (c/PVDF-s/ex. com PVDF, sem exercício); (s/PVDF-s/ex. - sem PVDF, sem exercício); (c/PVDF-c/ex. - com PVDF, com exercício); (s/PVDF-c/ex. - sem PVDF, com exercício); (c/PVDF-total. - todos os dados com PVDF); (s/PVDF total. - todos os dados sem PVDF).

Figura 19.16- Gráfico dos valores médios para área de fibrose. (c/PVDF-s/ex. - com PVDF, sem exercício); (s/PVDF-s/ex. - sem PVDF, sem exercício); (c/PVDFc/ex. - com PVDF, com exercício); (s/PVDF-c/ex. - sem PVDF, com exercício); (c/PVDF-total. - todos os dados com PVDF); (s/PVDF total. - todos os dados sem PVDF)

Figura 19.17 - Gráfico dos valores médios para volume de fibrose. (c/PVDF-s/ex. com PVDF, sem exercício); (s/PVDF-s/ex. - sem PVDF, sem exercício); (c/PVDF-c/ex. - com PVDF, com exercício); (s/PVDF-c/ex. - sem PVDF, com exercício); (c/PVDF-total. - todos os dados com PVDF); (s/PVDF total. - todos os dados sem PVDF)

Figura 19.18 - Gráfico dos valores médios para perímetro de remodelamento. (c/PVDF-s/ex. - com PVDF, sem exercício); (s/PVDF-s/ex. - sem PVDF, sem exercício); (c/PVDF-c/ex. - com PVDF, com exercício);(s/PVDF-c/ex. - sem PVDF, com exercício); (c/PVDF-total. - todos os dados com PVDF); (s/PVDF total. - todos os dados sem PVDF). 


\section{Lista de Tabelas}

Tabela 3.1 - Alguns polímeros de uso médico. ${ }^{[3] \ldots \ldots \ldots \ldots \ldots \ldots \ldots \ldots \ldots \ldots \ldots \ldots \ldots \ldots \ldots \ldots \ldots \ldots \ldots \ldots \ldots \ldots \ldots \ldots \ldots \ldots \ldots \ldots \ldots . . .} \quad 4$

Tabela 3.2 - Propriedades do vinilideno fluoreto ${ }^{[8]}$.................................................... 5

Tabela 4.1 - Índice de zona e índice de lise utilizados na avaliação da citotoxicidade (adaptado ${ }^{[65]}$ ).

Tabela 4.2 - Relação entre espessura do filme e razão área/quantidade de veículo de extração (adaptado ${ }^{[62,63]}$ ).

Tabela 4.3 - Possíveis reações causadas pelos extratos e controles aplicados intradermicamente (adaptada ${ }^{[61,62,67,68]}$ )...

Tabela 4.4 - Índices de Irritação Primária (adaptada $\left.{ }^{[61,62,67,68]}\right)$..................................... 29

Tabela 4.5 - Grupos para separação dos animais de teste........................................... $\quad 30$

Tabela 4.6 - Respostas dos ensaios conforme sintomas exibidos pelos animais inoculados com os extratos e os controles para o teste de toxicidade sistêmica. (adaptado ${ }^{[64,69,70]}$ ).

Tabela 5.1 - Comparação do coeficiente piroelétrico $\left(\mathrm{em} \mu \mathrm{Cm}^{-2} \mathrm{~K}^{-1}\right)$ medido antes $\left(\mathrm{p}_{1}\right)$ e depois $\left(\mathrm{p}_{2}\right)$ do processo de esterilização. As amostras foram polarizadas sob as mesmas condições................................................................................................... 46

Tabela 5.2 - Resultados de citotoxidade na leitura das placas de culturas celulares....... $\quad 47$

Tabela 5.3 - Resultado das Contagens de Irritação Primária para os animais ensaiados.

Tabela 5.4 - Tabela de pesos e índices de toxicidade sistêmica para os grupos das soluções ensaiadas..

Tabela 5.5 - Tabela de pesos iniciais (sem aplicação de extrato/veículo de extração) e finais para os grupos de animais conforme as das soluções ensaiadas.

Tabela 5.6 - Tabela de valores médios de peso corpóreo dos animais (g) e [ ] índice de toxicidade sistêmica para os grupos de animais conforme as das soluções ensaiadas.

Tabela 5.7 - Resultados estatísticos dos índices histomorfométricos.

Tabela 5.8 - Tabela com os resultados obtidos através de análise morfológica em microscópio óptico. $\mathbf{O}$ dimensionamento da formação de trabéculas ósseas recebeu uma graduação entre $(+)$ e $(+H+)$; o símbolo $(<+)$ represento uma formação extremamente baixa e (?) representa uma não identificação devido à perda de material biológico no ato da confeç̧ão da lâmina..

Tabela 10.1 - Planilha de anotações das reações para o teste de sensibilidade intracutânea. 
Tabela 10.2 - Exemplo de planilha utilizada para Contagem de Irritação Primária.......

Tabela 11.1 - Planilha para anotações dos dados obtidos no teste de toxicidade sistêmica

Tabela 11.2 - Planilha para anotações dos valores médios de peso corpóreo dos animais em gramas (g) e [índice de toxicidade sistêmica]

Tabela 12.1 - Exemplo de quadro do acompanhamento da situação de cada coelho......

Tabela 18.1 - Planilha de resultados para Contagem de Irritação Primária. Coelho Al.. 91

Tabela 18.2 - Planilha de resultados para Contagem de Irritação Primária. Coelho A2.. 92

Tabela 18.3 - Planilha de resultados para Contagem de Irritação Primária. Coelho A3.. 92

Tabela 18.4 - Planilha de resultados para Contagem de Irritação Primária. Coelho A4.. 93

Tabela 18.4 - Planilha de resultados para Contagem de Irritação Primária. Coelho A5.. 93

Tabela 19.1 - Planilha contendo valores mensurados e estatísticos de área total óssea, mineralizada ou não.

Tabela 19.2 - Planilha contendo valores mensurados e estatísticos de volume de osso totàl, mineralizado ou não.

Tabela 19.3 - Planilha contendo valores mensurados e estatísticos de área de osso mineralizado.

Tabela 19.4 - Planilha contendo valores mensurados e estatísticos de área medular...... 98

Tabela 19.5 - Planilha contendo valores mensurados e estatísticos de área osteóide...... 99

Tabela 19.6 - Planilha contendo valores mensurados e estatísticos de espessura osteóide

Tabela 19.7 - Planilha contendo valores mensurados e estatísticos de superficie osteóide

Tabela 19.8 - Planilha contendo valores mensurados e estatísticos de volume osteóide.

Tabela 19.9 - Planilha contendo valores mensurados e estatísticos de superficie osteoblástica.

Tabela 19.10 - Planilha contendo valores mensurados e estatísticos de superficie osteoclástica.

Tabela 19.11 - Planilha contendo valores mensurados e estatísticos de superfície de reabsorção.

Tabela 19.12 - Planilha contendo valores mensurados e estatísticos de área trabecular

Tabela 19.13 - Planilha contendo valores mensurados e estatísticos de espessura trabecular.

Tabela 19.14 - Planilha contendo valores mensurados e estatísticos de número trabecular.. 
Tabela 19.15 - Planilha contendo valores mensurados e estatísticos de separação trabecular.

Tabela 19.16 - Planilha contendo valores mensurados e estatísticos de área de fibrose.

Tabela 19.17 - Planilha contendo valores mensurados e estatísticos de volume de fibrose.

Tabela 19.18 - Planilha contendo valores mensurados e estatísticos de perímetro de remodelamento. 


\section{Lista de A6reviaturas e Siglas}

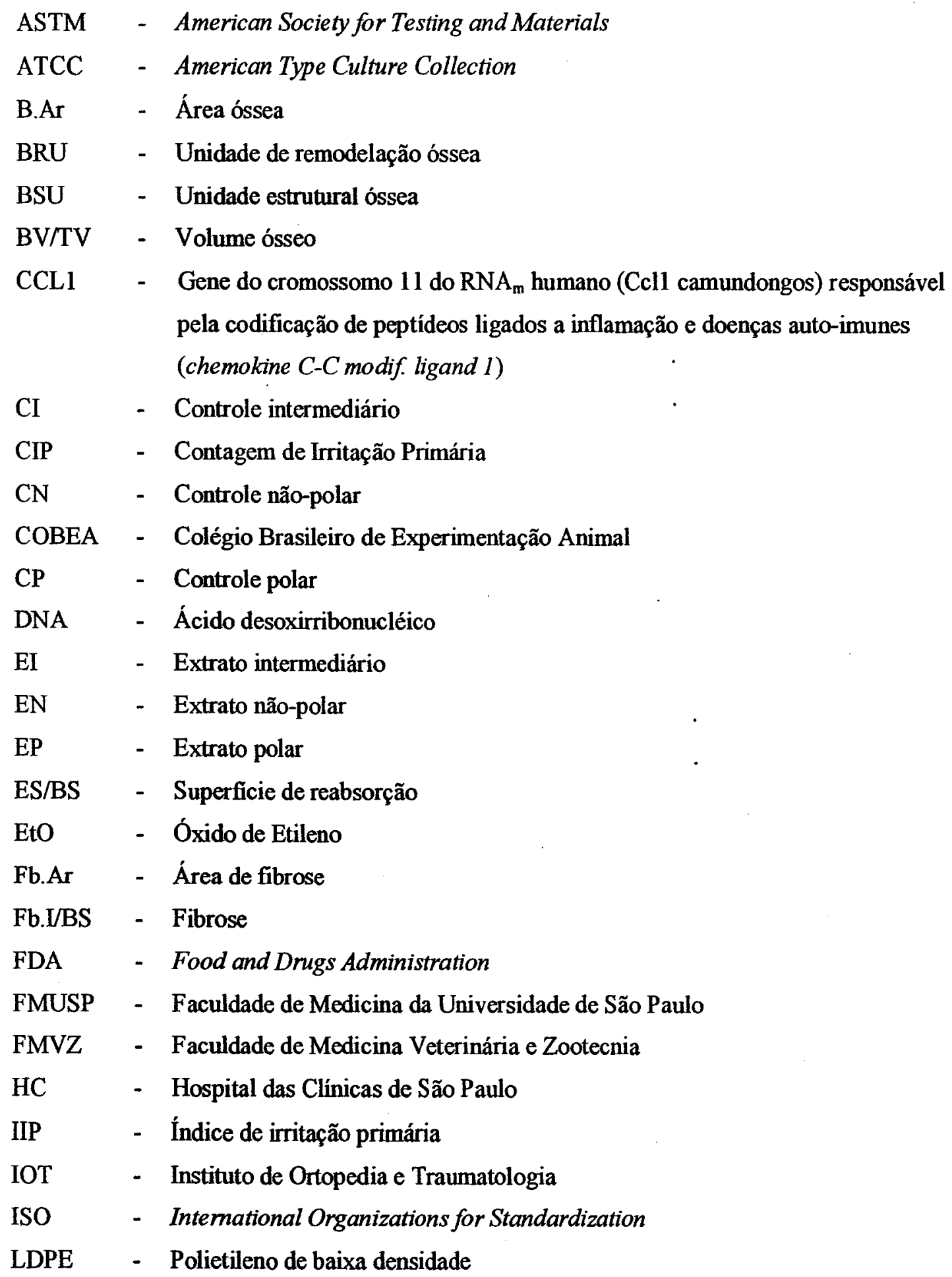


LIM - Laboratório de Investigação Médica

Ma.Ar - Área Medular

MAR - Taxa de aposição mineral

Md.Ar - Área de osso mineralizado

MEM - Meio Mínimo Essencial

NCTC - National Collection of Type Cultures

O.Ar - Área osteóide

O.Th - Espessura osteóide

Ob.S/BS - Superficie osteoblástica

Oc.S/BS - Superficie osteoclástica

OS/BS - Superfície osteóide

OV/BV - Volume osteóide

pH - Potencial de hidrogênio

Pm.Rm - Perímetro de remodelamento

PMMA - Polimetilmetacrilato

PTH - Hormônio paratireóide

PVDF - Fluoreto de poli (vinilideno)

PVPI - Polivinilpirrolidona-iodo

$\mathrm{RNA}_{\mathrm{m}}$ - Ácido ribonucléico mensageiro

Tb.N - Número trabecular

Tb.Pf.Ar - Área trabecular

Tb.Sp - Separação trabecular

Tb.Th - Espessura trabecular

UHMWPE - Polietileno de ultra-alto peso molecular

USA - United States of America

USP - Universidade de São Paulo

$\mathrm{v} / \mathrm{v} \quad$ - volume/volume

VEI - Veículo de extração intermediário

VEN - Veículo de extração não-polar

VEP - Veículo de extração polar 


\section{Resumo}

PASCHOAL, A.L. (2003). Estudo da viabilidade de aplicação do polímero piezelétrico fluoreto de polivinilideno (PVDF) entre osso cortical e placa de osteossíntese para estimulação de crescimento ósseo. São Carlos, 2003. 112 p. Tese (Doutorado) - Escola de Engenharia de São Carlos, Universidade de São Paulo.

O uso de biomateriais para acelerar reparos de fraturas ósseas tem aumentado nos últimos anos. Neste estudo, as propriedades piezelétricas do fluoreto de polivinilideno foram utilizadas com a finalidade de mimetizar os potenciais bioelétricos associados à deformação óssea, que são diminuídos quando ocorre fratura óssea. Estudos histomorfométricos foram efetuados para verificar a influência do polímero. Testes de biocompatibilidade e de esterilização permitiram avaliar os riscos da utilização do polímero como material de implante. $\mathrm{O}$ polímero piezelétrico associado à placa de osteossíntese resultou em uma maior quantidade de matriz óssea mineralizada na lesão quando comparado ao implante da placa sem o polímero

Palavras-chave: biomateriais, biocompatibilidade, PVDF, piezeletricidade, histomorfometria, osteossíntese. 


\section{A6stract}

PASCHOAL, A.L. (2003). Study of the viability of the piezoelectric poly(vinylidene fluoride) (PVDF) polymer application between cortical bone and osteosynthesis plate for growth bone stimulation. São Carlos, 2003. 112 p. Tese (Doutorado) - Escola de Engenharia de São Carlos, Universidade de São Paulo.

The use of biomaterials to promote accelerated bone fracture repair has been improved in the recent years. In the present study, the piezoelectric properties of poly(vinylidene fluoride) were used with the aim of mimetizing bioelectrical potentials associated to bone strain which decrease when a bone fracture occurs. Histomorphometric studies were accomplished to verify the influence of the polymer. Biocompatibility and sterilization tests assessed any risk related to the use of a polymer as an implantable material. The piezoelectric polymer associated to an osteosynthesis plate resulted in a larger amount of mineralized bone matrix in the lesion when compared to a plate implanted without the polymer.

Key-words: biomaterial, biocompatibility, PVDF, piezoelectricity, histomorphometry, osteosynthesis. 


\section{Objetivo}

Este trabalho tem como proposta avaliar o desempenho biológico do polímero piezelétrico PVDF (fluoreto de polivinilideno) atuando como estimulador de crescimento ósseo. Para isso serão avaliados alguns dos processos mais comumente utilizados em esterilização com o intuito de se verificar o comportamento da polarização do PVDF após a esterilização. Na seqüência serão efetuados testes de biocompatibilidade in vitro e in vivo, preconizados por Normas Técnicas, sendo escolhidos os mais representativos à sua aplicação. Com os resultados de biocompatibilidade positivos, o próximo objetivo consistirá em implantá-lo em contato a uma lesão provocada em tíbia de coelho, preso com uma placa de osteossíntese. Esperá-se observar, dado seu comportamento piezelétrico, um ganho no crescimento ósseo em um determinado espaço de tempo, após os coelhos serem submetidos a sedentariedade ou a exercícios físicos. $\mathrm{O}$ crescimento ósseo será avaliado através das técnicas de histomorfometria e histologia. 


\section{Introdução}

O osso, se observado como um material, pode ser considerado como um compósito ${ }^{[1]}$, onde um componente cerâmico (basicamente cristais de hidroxiapatita de cálcio e trifosfato de cálcio) e componentes biológicos estão presentes, apresentando propriedades biológicas, químicas, físicas e mecânicas peculiares. Entre essas propriedades pode-se citar a piezeletricidade.

Nas últimas décadas, muitas pesquisas tem sido feitas na área da ortopedia na tentativa de se obter técnicas e dispositivos para a obtenção de uma consolidação rápida, segura e com o mínimo de seqüela quando da ocorrência de traumas ou enfermidades no osso. Como exemplo, pode-se citar o caso de uma fratura em osso longo que, após a devida redução (quando necessária), pode ser tratada recorrendo a dispositivos como a tala, o gesso, os fixadores externos e internos, algumas pontes para crescimento ósseo, (como certas cerâmicas e polímeros que preenchem cavidades ósseas perdidas) e indutores de crescimentos, que mimetizam as propriedades mecânicas ósseas para que os componentes mecânicos e biológicos ósseos sejam estimulados a se desenvolverem, (como é o caso da aplicação de ultra-som para ativar a osteogênese, provavelmente pelo efeito piezelétrico presente no osso).

Quando da ocorrência de uma fratura, toda uma seqüência de fenômenos é ativada dentro do organismo para que esse trauma seja sanado e a atividade piezelétrica entra como um fator muito importante para a manutenção de cargas elétricas no local lesado, o que, segundo muitos estudiosos, atrai e ativa as células precursoras, que se diferenciam em células formadoras de tecido ósseo.

Cabe ressaltar que, devido ao crescente avanço tecnológico, novos materiais para implantes estão sendo testados a cada dia, como conseqüência também da crescente necessidade de aperfeiçoamento e pelo surgimento de novas técnicas de tratamentos clínicos, para um número cada vez maior de pacientes acometidos por enfermidades e traumas, que ocorrem por esse mesmo avanço tecnológico, na forma, por exemplo, de acidentes automobilísticos ou até mesmo na prática de esportes radicais. 


\section{Revisão Bibliográfica}

\subsection{Biomateriais}

Sejam os implantes biológicos ou sintéticos, a princípio, são materiais estranhos ao organismo hospedeiro, mas que na realidade irão proporcionar, a cura ou o restabelecimento de uma função perdida com maior velocidade e com boa margem de segurança. ${ }^{[2]}$

Esses materiais com características especiais são denominados genericamente de biomateriais e devem ser, em resumo, biocompatíveis com os organismos, anatomicamente funcionais, de alta resistência mecânica e química, possuir boa durabilidade (o necessário para cada tipo de aplicação), certa facilidade de fabricação, de relativo baixo custo e serem capazes de suportar, sem perderem suas propriedades, pelo menos um dos vários métodos de esterilização ${ }^{[2]}$. A Figura 3.1 apresenta um fluxograma conceitual, de forma resumida, da classificação dos biomateriais.

Dos materiais sintéticos, os polímeros têm ocupado uma boa parte dos dispositivos confeccionados, devido à facilidade de serem manuseados e, por apresentarem algumas propriedades mecânicas e químicas que podem vir a adquirir devido a tratamentos específicos. São facilmente obtidos em várias formas, tais como fibras, tecidos, filmes, sólidos e géis, podendo ser utilizados tanto na forma pura ou como constituinte de copolímeros e compósitos, mostrando, com essa versatilidade, o grande interesse por estes materiais, em vários setores da indústria, sendo uma boa parcela na confecção de dispositivos médicos e implantáveis. Na Tabela 3.1, são citados alguns polímeros que estão sendo mais freqüentemente utilizados em algumas áreas da medicina. 


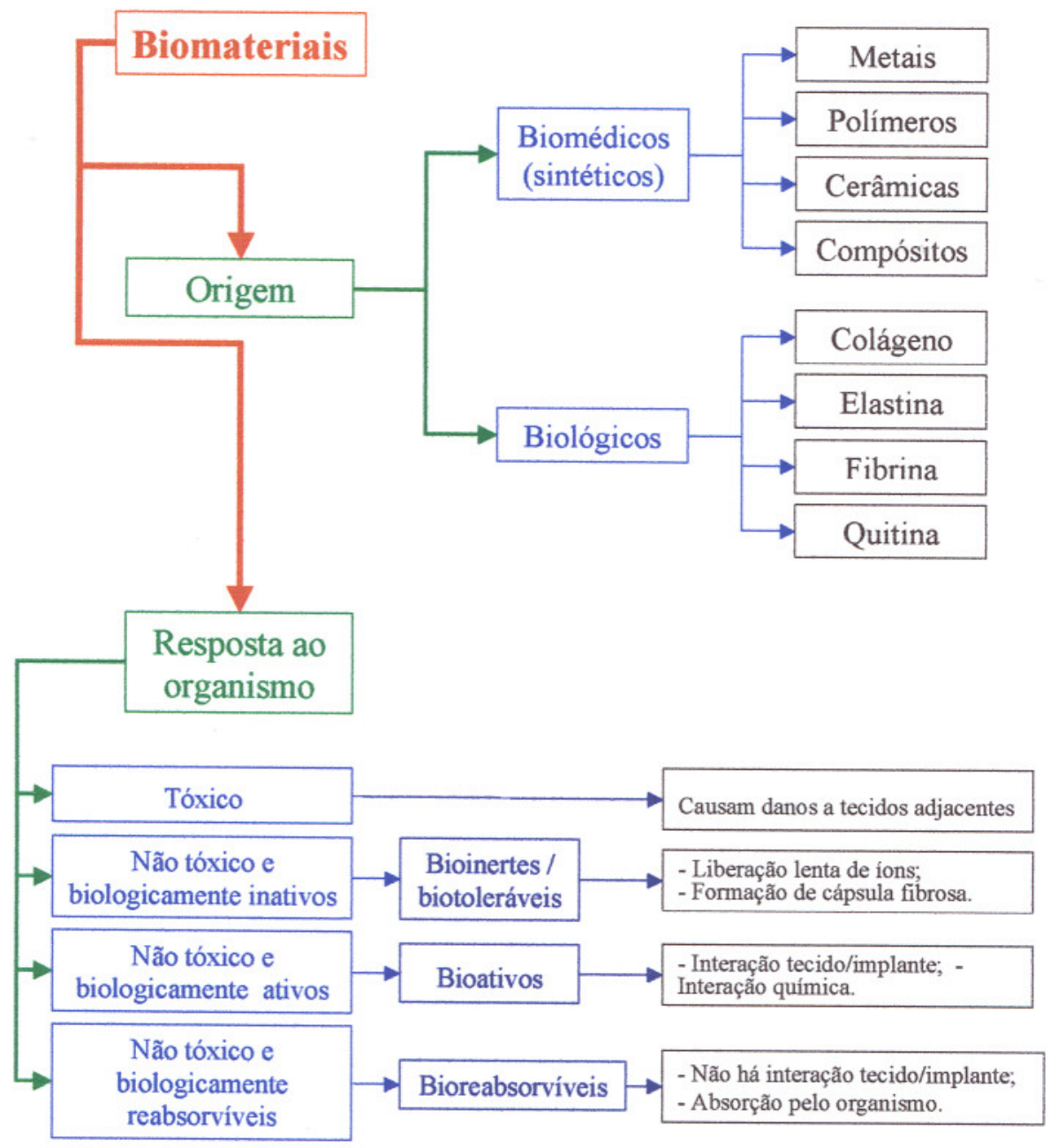

Figura 3.1 - Esquema da classificação dos biomateriais. (adaptado ${ }^{[1,3]}$ )

Tabela 3.1 - Alguns polímeros de uso médico. ${ }^{[3]}$

\begin{tabular}{ll}
\hline \multicolumn{1}{c}{ Polímero } & \multicolumn{1}{c}{ Aplicação } \\
\hline Polietileno (LDPE) & Cirurgia reconstrutiva \\
Polietileno (UHMWPE) & Ortopedia \\
Polimetilmetacrilato (PMMA) & Cimento ósseo \\
Borracha de silicone & Cirurgia plástica, ortopedia. \\
Poliacetal & Ortopedia \\
Ácido polilático & Suturas \\
Ácido poliglicólico & Suturas \\
Resina epoxi (compósitos) & Ortopedia \\
Poliéster (Dacron®) & Cardiovascular \\
Poliamidas & Suturas \\
Fluorpolímeros & Cirurgias gerais, cardiovasculares. \\
Hidrogéis & Oftalmologia \\
Poli (vinil cloreto) & Tubulações \\
\hline
\end{tabular}




\subsection{Fluoreto de polivinilideno (PVDF)}

Há algum tempo a piezeletricidade ${ }^{1}$ vem despertando interesse na área biológica, pois algumas estruturas naturais e biopolímeros, tais como certas madeiras, bambu, osso, tendão, dente, pele, traquéia, (tecidos que apresentam grande quantidade de colágeno), filmes orientados de DNA, polipeptídios, poliaminoácidos (como o poli- $\gamma$-metilglutamato, polialanina, polileucina, entre outros) apresentam piezeletricidade. ${ }^{[4]}$

O fluoreto de polivinilideno (polivinilideno fluoreto ou polifluoreto de vinilideno), mais conhecido pela sua sigla PVDF, é o polímero sintético de maior piroeletricidade ${ }^{2}$ e piezeletricidade já investigado e seu uso vêm crescendo bastante na tentativa de indução dessas propriedades em tecidos biológicos que também apresentam essas propriedades.

$\mathrm{O}$ monômero de vinilideno fluoreto, $\mathrm{CH}_{2}=\mathrm{CF}_{2}$, foi primeiramente sintetizado em 1901 por Swarts ${ }^{[8]}$. Algumas propriedades são apresentadas na Tabela 3.2.

Tabela 3.2.- Propriedades do vinilideno fluoreto ${ }^{[8]}$.

\begin{tabular}{lc}
\hline Propriedades & Valor \\
\hline Fórmula química & $\mathrm{CH}_{2}=\mathrm{CF}_{2}$ \\
Peso molecular & 64 \\
Ponto de ebulição, ${ }^{\circ} \mathrm{C}$ & -86 \\
Ponto de congelamento, ${ }^{\circ} \mathrm{C}$ & -144 \\
Pressão crítica, $\mathrm{kPa}$ & 4450 \\
Temperatura critica, ${ }^{\circ} \mathrm{C}$ & 30 \\
Densidade crítica, $\mathrm{g} / \mathrm{ml}$ & 0,416 \\
Momento dipolo, debye & 1,96 \\
Condutividade térmica, $20^{\circ} \mathrm{C}^{\circ}\left(\mathrm{Wm}^{-2}\right)\left(\mathrm{mK}^{-1}\right)$ & 0.723 \\
Capacidade calorífica a $20^{\circ} \mathrm{C}, \mathrm{cal} \mathrm{mol}^{-1} \mathrm{~K}^{-1}$ & 13.6 \\
Potencial de ionização, eV & 10.3 \\
Calor de formação, kcal mol ${ }^{-1}$ & -77.5 \\
\hline
\end{tabular}

Para a produção de filmes piezelétricos, existe uma variedade de técnicas. Para o PVDF, o filme deve ser mecanicamente estirado e polarizado. Filmes produzidos sem o devido estiramento apresentam propriedades piroelétricas e piezelétricas muito fracas. Tipicamente, quanto maior o grau de orientação molecular, maior será as atividades resultantes para o filme piezelétrico. Algumas técnicas de polarização incluem: extrusão de filme (filme fundido, co-extrusão, filme soprado e laminação térmica), fundição do filme por solvente, utilizando técnicas de orientação (orientação uniaxial, estiramento em estufa, rolo de tração, e de compressão entre outros) e, finalmente, algumas técnicas de polarização (térmica, corona, alto campo a temperatura ambiente e polarização durante a orientação).

\footnotetext{
1 Piezeletricidade (do grego piezein = pressionar) é a capacidade de certos materiais cristalinos de mudar suas dimensð̌es quando sujeitos um campo elétrico, ou, inversamente, produzir sinal elétrico quando mecanicamente deformado ${ }^{[6,7]}$.

${ }^{2}$ Um material é dito Piroelétrico quando uma mudança na polarização elétrica indủz uma temperatura detectável; ou reversamente, quando exposto a uma variação de temperatura, pode ser detectado por uma polarização elétrica proporcional. ${ }^{[S]}$
} 
A conversão de energia térmica para energia elétrica usando materiais piroelétricos já é conhecida há muito tempo, mas somente a partir de 1880, que os irmãos Jacques e Pierre Curies ${ }^{[9,10]}$ descobriram que em alguns cristais, submetidos a uma energia mecânica externa, esta energia era convertida com alta eficiência para energia elétrica. Em 1969, Kawai ${ }^{[9,11,12]}$, descobriu que esse forte efeito, o efeito piezelétrico, poderia ser induzido em um polímero pela aplicação de um campo elétrico. Esse polímero é o polivinilideno fluoreto.

Dois anos depois, Bergman et. al e Wada descobriram que filmes poliméricos polarizados desta mesma forma também exibiam piroeletricidade. ${ }^{[9,11]}$

Estas descobertas foram importantes marcos para o campo dos transdutores piroelétricos e eletromecânicos.

Como o PVDF apresenta as propriedades de piroeletricidade e piezeletricidade, é de grande flexibilidade, fácil de ser fabricado e de baixo custo, ele continua sendo um material muito utilizado em microfones, alto-falantes, fones de ouvido, transdutores ultra-sônicos para aplicações dentro da água, tais como hidrofones e aplicações para obtenção de imagens médicas, transdutores eletromecânicos para computadores e teclas de telefone e uma variedade de outras aplicações que exijam contato, detectores piroelétricos para imagens por infravermelho, etc. ${ }^{[12]}$

Materiais piezelétricos e piroelétricos são caracterizados pela ausência de um centro de simetria da unidade estrutural microscópica, no qual dipolos elementares são alinhados de uma maneira paralela e sentido elétrico similar. O PVDF é inerentemente polar. Os átomos de hidrogênio são positivamente carregados e os átomos de flúor, negativamente com relação aos átomos de carbono no polímero. É reconhecido que a atividade elétrica do PVDF se dá devido à rotação do monômero $\mathrm{CH}_{2}=\mathrm{CF}_{2}$, que é muito polar, sobre o eixo da cadeia do polímero quando da aplicação de um campo elétrico, permanecendo orientado mesmo quando o campo é removido. ${ }^{[9,13]}$ Quando o polímero é deformado, todos esse grupos também tendem a se alinhar. Esquemas dos monômeros e da cadeia polimérica podem ser vistos na Figura 3.2.

$\mathrm{Na}$ fase líquida, a molécula muda continuamente sua forma devido às rotações sobre as ligações carbono-carbono. A média do momento dipolo de um grupo de moléculas em uma região líquida é zero na ausência de um campo elétrico, por causa das orientações aleatórias de dipolos individuais. Já na fase cristal, certas conformações moleculares regulares são energicamente favoráveis ao empacotamento cristalino. ${ }^{[14]}$ 

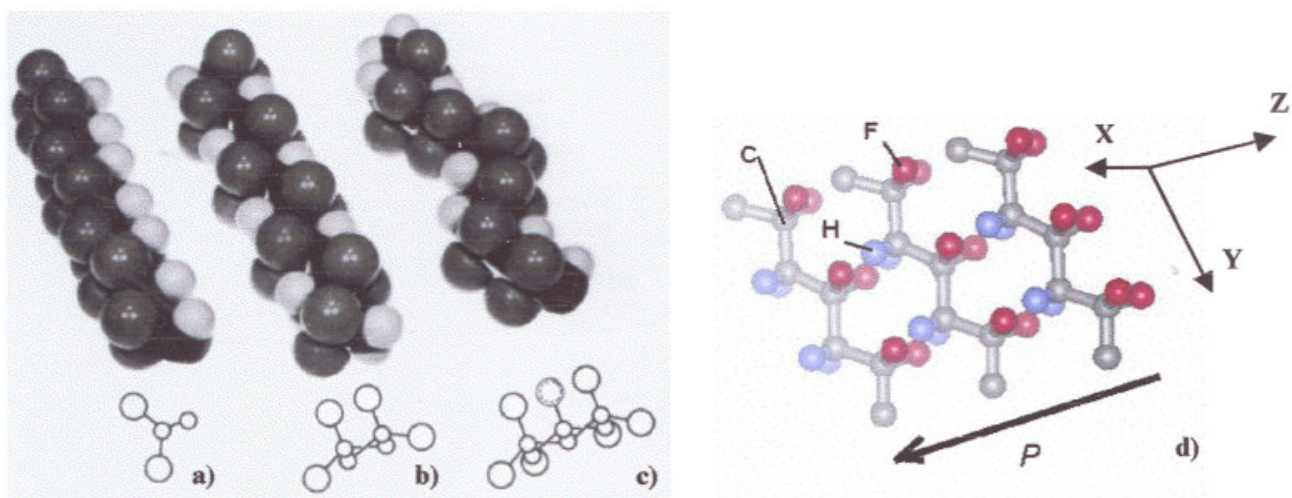

Figura 3.2 - Esquema dos modelos espaciais do PVDF em três conformações concluídas de análises estruturais de cristais. $O$ diagrama indica os átomos de carbono e de flúor visualizados paralelamente ao eixo da cadeia. Os átomos de hidrogênio foram omitidos nos esquemas a,b e c. As imagens c e d mostram a rotação da forma $\beta$ do PVDF molecular, que ocorre quando está sob influência de um campo elétrico (PVDF em um plano "zig-zag"). Isto indica que os átomos de flúor estão alinhados a um campo elétrico. $\mathrm{P}=$ polarização. $\mathbf{O}$ eixo $\mathrm{Y}$ é paralelo à cadeia; $\mathbf{Z}$ é o eixo polar (adaptado ${ }^{[6,9]}$ ).

Na temperatura ambiente todas as estruturas cristalinas são duradouras (quer estáveis ou metaestáveis) e têm unidade celular polar, ou seja, um cristal de momento polar $\alpha, \beta$, ou $\gamma$ tem um momento dipolo livre. A transformação na fase cristal pode ocorrer por estiramento mecânico, altas temperaturas de recozimento ou aplicação de campo elétrico. 


\subsubsection{Aplicações biomédicas}

O PVDF tem sido utilizado, na maioria das vezes como material para confecção de transdutores, por serem dispositivos altamente especializados que trabalham em condições dificeis, tal como o delicado, mas agressivo, fluído corpóreo. Na sua grande maioria, estes transdutores são requisitados a serem miniaturizados e eventualmente a permanecerem implantados por longos períodos de tempo. A demanda sobre os materiais para serem usados como dispositivos para aplicações biomédicas depende principalmente do nível de interação do dispositivo com o sistema biológico.

Em aplicações médicas, com exceção de dispositivos que são utilizados externamente ao corpo humano e aqueles planejados para exercer função em contato com a pele, devem-se considerar não somente os requisitos mecânicos e propriedades físicas, mas também a já muito debatida influência sobre o meio biológico, assim como o reverso, a influência do meio biológico sobre o material.

É importante ressaltar alguns aspectos tais como a absorção da água pelo PVDF que é extremamente baixa (menos que $0,04 \%$ por peso, segundo o que se foi medido pela norma ASTM DS 70) e que o homopolímero PVDF é considerado não tóxico, podendo ser utilizado por repetidas vezes em contato com alimentos (por exemplo, como material para embalagens) de acordo com o U.S Code of Federal Regulations, Título 21 - Food \& Drugs, Capitulo F, pág. 21. Outra pesquisa registrou que o PVDF não apresentou respostas adversas toxicológicas ou biológicas quando esse material era ingerido, inalado ou implantado em animais sob condições controladas. ${ }^{[16]}$ Não é possível encontrar na literatura extensivos estudos sobre interações material-sangue ou material-tecido, porém De Rossi (apud Mason et.al) ${ }^{[16]}$ cita o registro de ser o PVDF um material de características intermediárias em ensaios de compatibilidade sangüínea realizada através de teste in vitro.

Outra característica importante é a esterilização. Dependendo do tipo de contato com o corpo, pode-se adotar um ou outro tipo de esterilização ou desinfecção ${ }^{3}$, baseado na seguinte classificação: Dispositivos considerados críticos são os itens e instrumentos que necessitam esterilização antes e após sua utilização. São os itens que entram em contato com tecido estéril e sistema vascular. São exemplos os instrumentos cirúrgicos que penetram nos tecidos moles ou entram em contato com o tecido ósseo, cateteres cardíacos, endoscópios que penetram em tecidos estéreis e cavidades. É nessa classificação que os materiais implantáveis, incluindo o PVDF devem ser classificados. Os semi-criticos envolvem os instrumentos que não penetram em tecidos estéreis ou osso, mas entram em contato com

\footnotetext{
3 Esterilização constitui na destruiçăo total de microorganismos, de um material ou ambiente, quaisquer que sejam eles. Desinfetar trata-se de um caso particular de esterilização, significando apenas eliminar os microorganismos patogênicos, sem que haja necessidade da destruição total dos germes, uma vez que os microorganismos patogênicos são menos resistentes que os saprófitas. ${ }^{[15]}$
} 
membranas mucosas ou em pele não intacta. Se o dispositivo não puder passar por processo algum de esterilização por não suportar calor, deve-se no mínimo passá-lo por um processo de desinfecção de alto nível, onde se consegue chegar a uma destruição ou inativação de $100 \%$ dos agentes patogênicos, mas não necessariamente de esporos. Os dispositivos classificados como não-críticos são instrumentos que apenas entram em contato com a pele quando íntegra, como é o caso de alguns transdutores (incluindo os construídos com PVDF) e standoff-pads de aparelhos de ultra-sonografia. Essa superficie possui um baixo risco de transmissão de infecções e pode passar por processo de desinfecção de baixo nível, no qual a desinfecção ou inativação ocorre apenas em alguns microorganismos patogênicos. ${ }^{[17,18]}$

A perda da irreversibilidade de polarização residual ocorre a aproximadamente $70^{\circ} \mathrm{C}$, com uma diminuição quase linear nas respostas residuais piezelétrica e piroelétricas em aproximadamente $1 \%$ por ${ }^{\circ} \mathrm{C}$. Isso deve ser levado em conta para se providenciar cuidados especiais ao se esterilizar dispositivos feitos a partir desse material. Exposições ao óxido de etileno ou irradiações por emissão de elétrons ou fonte radioativa (por exemplo, radiação gama) podem ser uma alternativa, porém deve-se atentar à temperatura de atuação do óxido de etileno para que não ocorra nenhum tipo de ataque químico e para que a exposição a irradiações não ultrapasse a ordem de $2.5 \mathrm{Mrad}$. Como exemplo, podemos citar que, com uma irradiação de 2,5 Mrad partindo de uma fonte de ${ }^{60} \mathrm{Co}$, o filme de PVDF ainda retém completamente sua polarização. ${ }^{[16]}$

Alguns dos principais dispositivos médicos que utilizam o PVDF são: Sensores, como os cardiopulmonares não invasivos, transdutores internos implantáveis e sensores para próteses, órteses e dispositivos de reabilitação ${ }^{[16]}$ e transdutores para ultra-som ${ }^{[6,19,20]}$, os Atuadores, que utilizam o efeito inverso da piezeletricidade, ou seja, são capazes de controlar movimentos e forças mecânicas com impulsos elétricos, como microinjetores e membranas vibráteis e os Geradores de Carga, onde estão suprimentos fisiológicos de energia implantáveis (órgãos artificiais) ${ }^{[16]}$ mais recentemente, outras aplicações para o PVDF tem sido estudadas, como por exemplo, na endotelialização vascular ${ }^{[21]}$, regeneração nervosa ${ }^{[22,23]}$, construção de malhas cirúrgicas para reparo de hérnias abdominais ${ }^{[24]} \mathrm{e}$ implante para promoção de crescimento ósseo, (que será o alvo deste trabalho). ${ }^{[16,25]}$ 


\subsection{Osso}

Olhando-o como um material, o osso pode ser considerado um compósito bastante interessante, por apresentar características mecânicas e biológicas muito peculiares. Do ponto de vista biológico, tanto é um tecido estrutural como um tecido metabólico, capaz de se remodelar de acordo com sua necessidade. O tecido ósseo é o mais resistente e rígido do corpo humano e entre suas principais funções estão a de servir de suporte para tecidos moles e proteção de órgãos vitais (como a caixa craniana, torácica e o canal raquidiano), alojar e também proteger a medula óssea, que formam as células vermelhas e brancas do sangue, responsáveis, respectivamente, pela oxigenação e imunoproteção dos outros tecidos. Os músculos esqueléticos estão apoiados em determinados sistemas ósseos, onde juntos, são responsáveis pelos complexos movimentos do corpo, através de sistemas de alavancas que ampliam as forças geradas pelas contrações musculares. O osso serve também como depósito de alguns íons, tais como cálcio, fosfatos, magnésio, sódio, potássio, carbonatos, entre outros, que, armazenando-os e liberando-os, controla suas concentrações no metabolismo corpóreo. ${ }^{[26,27,28]}$

São divididos macroanatomicamente em dois grupos: os ossos corticais ou compactos, abrangendo aproximadamente de 70 a $80 \%$ do osso corpóreo total, com espaços apenas para os osteócitos, canalículos e vasos sanguíneos, e os ossos trabeculares ou porosos, representando em torno de 20 a $30 \%$ do osso corpóreo total. ${ }^{[27,28,29,30]}$ A Figura 3.3 mostra o corte de um fêmur humano onde é possível observar tanto o osso cortical como o trabecular.

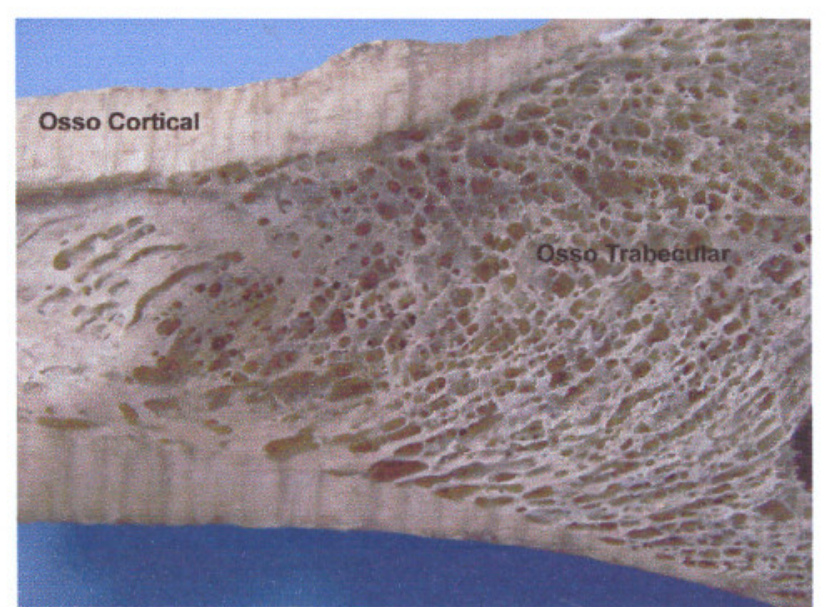

Figura 3.3 - Osso cortical e osso trabecular de fêmur humano. (foto obtida de peça anatômica do Departamento de Bioengenharia da USP São Carlos)

A nível celular, o tecido ósseo é constituído de uma matriz extracelular, onde estão os componentes orgânicos (aproximadamente 35 \%) e os inorgânicos (65\%). O colágeno, 
que participa ativamente no processo de mineralização óssea, abrange em torno de $90 \%$ da matriz orgânica, enquanto que os $10 \%$ restantes correspondem as glicoproteínas, mucopolissacarídeos ácidos e lipídeos. A hidroxiapatita, a parte mineral do osso, composta basicamente pelos sais de cálcio e fosfato, forma uma estrutura de elevada dureza, resistente a tensões compressíveis, enquanto que as fibras de colágeno fornecem resistência tênsil ao osso. ${ }^{[30,31]}$

O osso in vivo é considerado como um tecido adaptável, ou seja, forças externas sobre ele aplicadas exercem função de colocá-lo mecanicamente em uma posição ideal para que suporte esse esforço (desde que gradualmente e a longo tempo aplicado, pois uma carga excessiva imposta de uma só vez poderia causar trauma). Essa adaptação ou remodelamento ósseo é o fenômeno biológico que atua neste sentido e que naturalmente se expressa no organismo, pois, uma vez que o osso é composto por cristais mineralizados, é necessário que esses cristais sejam degradados para dar lugar a uma nova formação óssea reestruturada para acompanhar essa adaptação ou, por exemplo, o desenvolvimento de uma criança.

O remodelamento ósseo não ocorre apenas no desenvolvimento ou em uma aplicação de esforço anormal. Embora em uma intensidade menor, esse é um fenômeno que ocorre por toda a vida. Basicamente são realizados por dois tipos de células, os osteoclastos e os osteoblastos.

Os osteoclastos são células que apresentam mobilidade e migram sobre a superfície óssea (Figura 3.4). São multinucleadas devido a fusão de precursores mononucleados da medula hematopoiética, principalmente da linhagem granulócitos-macrófagos. Apresenta citoplasma com abundantes mitocôndrias, vacúolos e vesículas envolvidas na reabsorção. Nesses vacúolos estão contidas enzimas lisossômicas que digerem a matriz orgânica e inorgânica em meio ácido. A Figura 3.4 mostra alguns aspectos do papel dos osteoclastos na absorção óssea, onde enzimas lisossômica, concentradas com complexo golgiano são liberadas devido a um estimulo e seguem para um destino programado. Essas enzimas e íons de hidrogênio (produzidos por anidrase carbônica) são liberados a um local pré-determinado pelo osteoclasto criado pela aderência na matriz óssea e a zona clara do citoplasma (sítio de adesão). Ao mesmo tempo, o osteoclasto abaixa o pH deste compartimento pelo bombardeamento ativo de prótons através da membrana apical, que é a "escova" em contato direto com a área de reabsorção. Essa área de reabsorção é denominada lacuna de Howship. A acidez desse microambiente ideal para a atividade de hidrolases lisossômicas facilita então a dissolução de fosfato de cálcio, e com isso a matriz óssea é removida e os produtos da absorção óssea são capturados pelo citoplasma do osteoclasto, digeridos ainda mais e transferidos para capilares sanguíneos. ${ }^{[27,30,32,33,34]}$ 


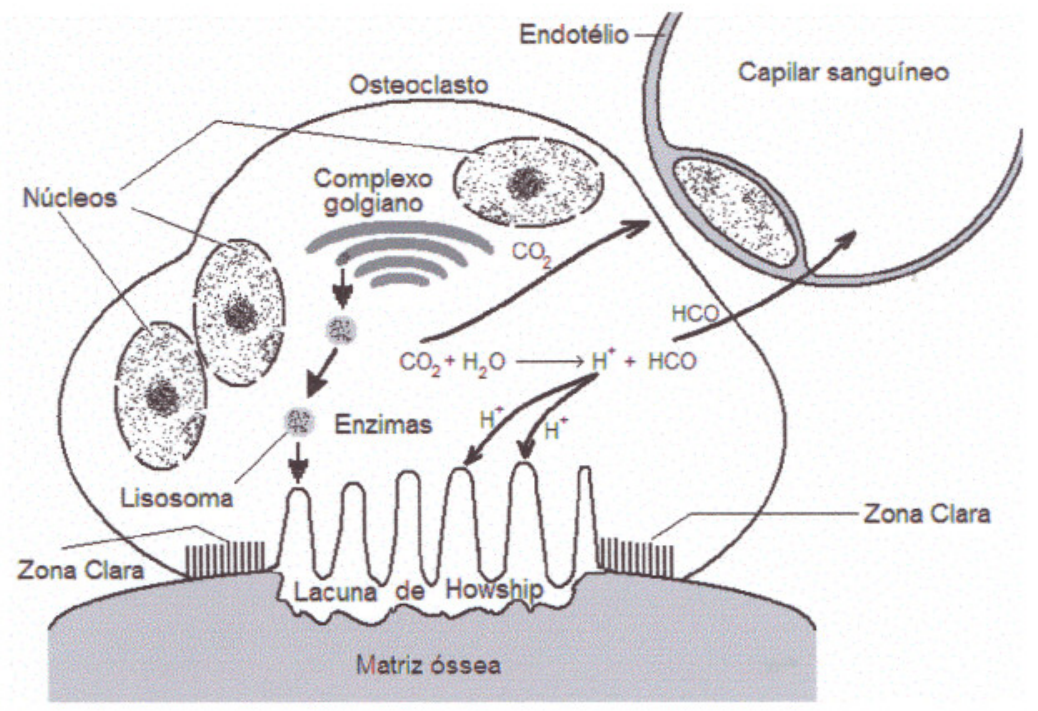

Figura 3.4 - Esquema de alguns aspectos do papel do osteoclasto na reabsorção. (adaptado ${ }^{[27]}$ ).

Osteoblastos são células tipicamente cuboidais (Figura 3.5), derivadas de células progenitoras mesenquimais indiferenciadas, apresentam complexo golgiano e retículo endoplasmático muito desenvolvidos, o que caracteriza sua adaptação a biossíntese e a secreção de matriz orgânica. Expressam ainda fosfatase alcalina, osteocalcina, colágeno, colagenase, receptores para $1,25(\mathrm{OH})_{2}$ - vitamina $\mathrm{D}$, glicocorticóides PTH e uma variedade de fatores de crescimento. Resumindo, é a célula produtora de novo osso. ${ }^{[27,30,32,33]}$

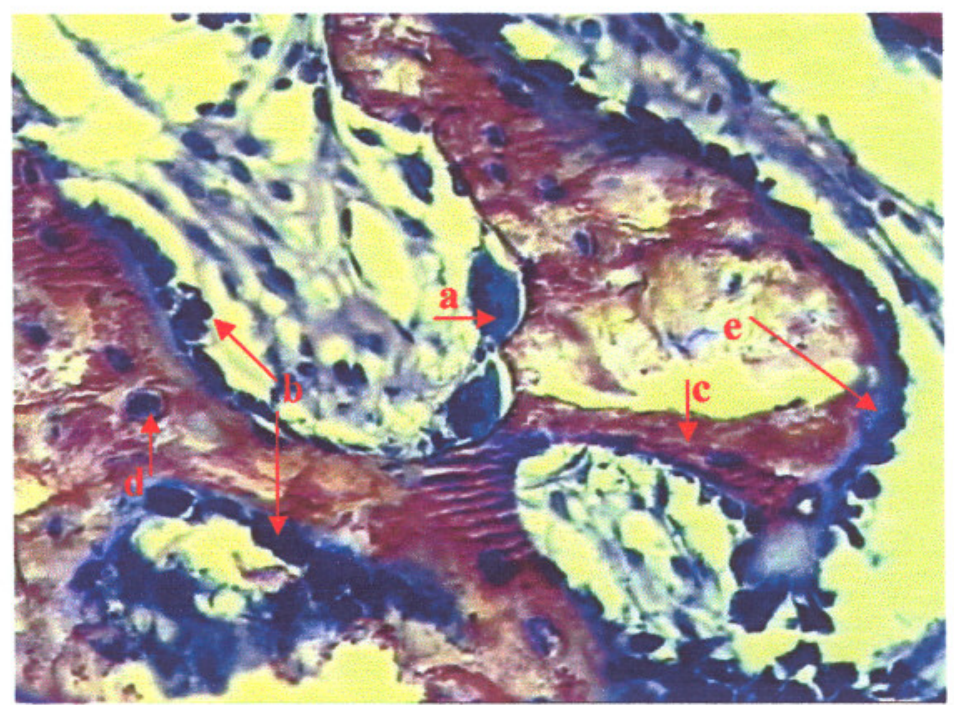

Figura 3.5 - Foto de cortical de tíbia de coelho não descalcificada: a) osteoclasto; b) osteoblastos; c) osso mineralizado; d) osteócito; e) osteóide (matriz não mineralizada). Corante Azul de Toluidina.

A remodelação óssea caracteriza-se por ser um processo cíclico e de longa duração que ocorre principalmente por intermédio das duas células citadas: Os osteoclastos, responsáveis pela reabsorção e os osteoblastos, responsáveis pela reposição. O resultado da atividade dessas células é uma verdadeira escavação óssea e liberação, para a corrente 
circulatória, de produtos da degradação do tecido ósseo, como por exemplo, aminoácidos e íns. Uma vez completada esta fase, os osteoclastos deixam o local da reabsorção e, após vários dias, são substituídos por osteoblastos. $\mathrm{O}$ resultado da atividade dessas células é o preenchimento das cavidades deixadas pelos osteoclastos com tecido ósseo recémsintetizado. Essa seqüência de eventos, na verdade, constitui um mecanismo de autoreparação da estrutura óssea, preservando a massa óssea e a sua arquitetura. Observe os esquemas de remodelamento ósseo cortical e trabecular nas Figuras 3.6 e 3.7 respectivamente. $^{[29]}$

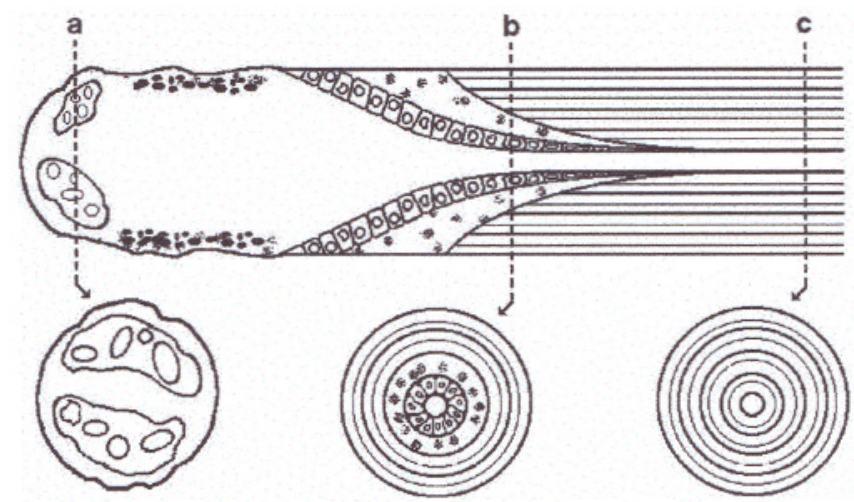

Figura 3.6 - Atividade da unidade de remodelação óssea $(B R U)$ em osso cortical em vista longitudinal e subseqüente vista transversal. a) osteoclastos escavam um túnel, criando um "cone de abertura". b) Em seguida, novo osso é formado na área do "cone de fechamento" c) conduzindo a criação de uma nova unidade estrutural óssea $(B S U)$, isto é, osteon cortical ou sistema haversiano. (adaptado ${ }^{[29]}$ ).

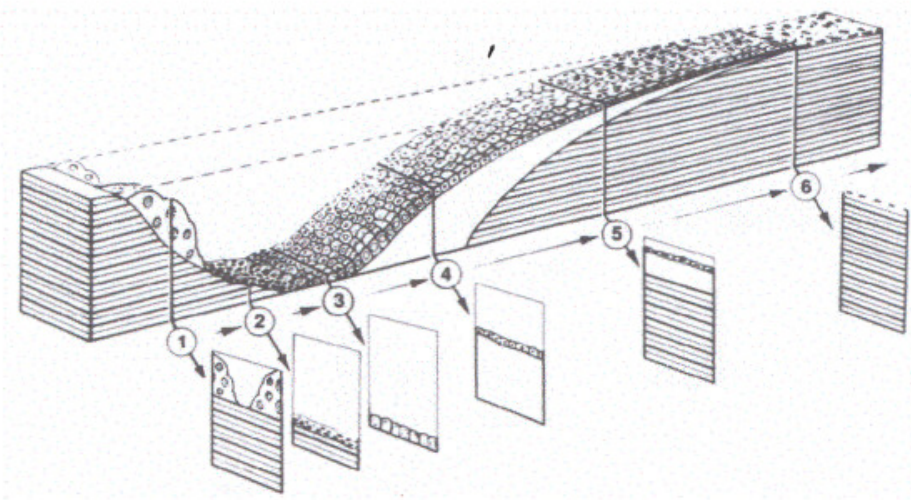

Figura 3.7 - Esquema da atividade da unidade de remodelamento ósseo (BRU) em osso trabecular em vista longitudinal e subseqüente vista transversal. a BRU do osso trabecular pode ser comparada a uma BRU cortical cortada ao meio. Cinco diferentes fases podem ser diferenciadas: 1) reabsorção osteoclástica; 2) reabsorção mononuclear; 3) migração proosteoblástica e diferenciação para osteoblastos; 4) formação de matriz osteoblástica (osteóide); 5) mineralização, 6) 0 produto final do remodelamento é a unidade óssea estrutural (BSU) trabecular, ou seja, osteon trabecular, recoberto por células. ${ }^{[29]}$

As figuras acima mostram que, quando os osteoclastos estão saindo do local já absorvido, os osteoblastos entram nas lacunas deixadas e começam o início da formação do novo osso. A primeira estrutura a aparecer é a matriz óssea não calcificada, chamada de osteóide ( $90 \%$ composto de colágeno Tipo I). Entre o osteóide e em vias de mineralização e 
o osso mineralizado é a região conhecida como frente de mineralização. A mineralização é um processo controlado basicamente pelos osteoblastos, através da regulação da concentração iônica local e modulação dos níveis de proteínas e fatores que inibem ou estimulam esse mineralização. Ao dar início a mineralização, os osteoblastos criam um microambiente livre de inibidores de cristalização, onde ocorre basicamente, a precipitação dos cristais de hidroxiapatita em associação com as fibras de colágeno. A fosfatase alcalina atua no auxílio dessa mineralização, pois ela age localmente na diminuição da efetividade dos inibidores locais de calcificação e no aumento da concentração de fosfato. ${ }^{[26,27,28,29,30]}$ Quando a matriz inicia a mineralização, alguns dos osteoblastos ficam aprisionados. Estes serão os osteócitos. Cada osteócito ocupa uma lacuna que estabelece contato com uma outra através de uma rede de canalículos, sua morte implica em reabsorção óssea.

No entanto, os exatos mecanismos implicados na gênese do tecido ósseo são muito controversos, onde fatores locais e sistêmicos estão envolvidos e alguns mediadores promovem um equilíbrio contínuo nos processos de formação óssea pelo osteoblasto e reabsorção, pelo osteoclasto. Sabe-se que tensões mecânicas exercem influência sobre a remodelação óssea, como por exemplo, o trabalho de um aparelho ortodôntico sobre a arcada dentária para modificá-la através de pressões laterais. Ocorre reabsorção óssea no lado em que a pressão atua e deposição do lado oposto. Enquanto o dente praticamente "caminha", o osso alveolar vai sendo remodelado.

A mecanotradução óssea é uma teoria onde osteoblastos e osteócitos seriam capazes de traduzir os efeitos mecânicos aplicados em estímulos de formação e reabsorção óssea. ${ }^{[26]}$

\subsubsection{Estimulação elétrica do crescimento ósseo.}

Vários pesquisadores têm estudado o fenômeno elétrico do osso desde que Yasuda, Fukada, Basset e Becker reportaram o fenômeno da eletricidade produzida quando ossos eram artificialmente deformados (fenômeno piezelétrico). A osteogênese tem sido então demonstrada quando estímulos elétricos são aplicados em culturas celulares e em experimentos em animais vivos. ${ }^{[35,36,37,38]}$

Quando submetidos a esforços, os ossos apresentam diferenças de potencial surgindo uma pequena corrente elétrica. Se o osso é vergado, um potencial negativo surge na região de compressão e ocorre o deslocamento de elétrons da região original da estrutura cristalina migrando para o local de compressão. Em contrapartida, na região em que o osso está sendo tracionado existe uma ausência de elétrons, deixando o local com potencial positivo. Essas cargas negativas têm a propriedade de ativar células precursoras de osteoblastos que estão nas camadas mais internas do periósteo. Deformação, com conseqüente geração de 
potenciais elétricos, caracteriza o osso como um material piezelétrico. É afirmado por alguns pesquisadores que osteoblastos, células formadoras dos ossos, são ativadas em regiões negativamente polarizadas enquanto que os osteoclastos, as células de reabsorção óssea, são ativadas em regiões de polarização positiva. ${ }^{[7,39]}$

Yassuda, já em 1953, pesquisava sobre esse assunto. Ele foi o primeiro a reportar a aplicação de corrente contínua de $1 \mu \mathrm{A}$ durante trinta dias produzindo a formação de calo no fêmur de coelhos e, desde então, vários desenvolvimentos clínicos têm sido aplicados para o reparo de fraturas ósseas, tais como correntes contínuas, alternadas, pulsadas e campos eletromagnéticos, tanto invasivas como não-invasivas e, mais recentemente, os ultra-sons (trabalhando o crescimento ósseo mecanicamente através do movimento ósseo obtido pelo som). ${ }^{[39,40,41]}$

Fukada ${ }^{[39]}$ cita ainda que Friedenber, Dyer e Brighton, em 1971 observaram o potencial de corrente contínua no crescimento de ossos de coelhos, com a metáfise sendo mais eletronegativa em comparação com a diáfise. Quando o osso era fraturado, a maior eletronegatividade foi observada no local da fratura, em regiões positivamente ativadas.

Como a piezeletricidade está relacionada diretamente as tensões aplicadas, o movimento é um fator importante para a manutenção da atividade metabólica do osso. A perda de massa óssea é reportada em astronautas quando estes permanecem no espaço por longo tempo devido à ausência de gravidade. Com isso, pode-se supor que a tensão mecânica aplicada no osso produz o potencial elétrico devido à piezeletricidade ou proveniente do potencial de escoamento e que, esse potencial elétrico, influencia na atividade metabólica das células. No lugar de potencial elétrico natural, espera-se que este possa ser substituído externamente com a aplicação de energia elétrica, como cita Basset, 1971 (apud Gjelsvisk) ${ }^{[42]}$, ou internamente, por materiais piezelétricos implantáveis.

Como já dito, estudiosos perceberam que grande parte da piezoeletricidade do osso é devido ao colágeno nele contido. Como o colágeno é a base para a aposição do componente mineral ósseo, e este é basicamente sintetizado pelos osteoblasto, que apresenta taxia por regiões eletronegativas, a grande atenção é para que, de alguma forma, consiga-se ampliar essa migração a locais injuriados, de forma artificial, através de dispositivos que induzam campo elétrico local. ${ }^{[43,44]}$ Embora esta influência de estímulos elétricos no desenvolvimento sequencial da diferenciação dos osteoblastos e subsequente biomineralização ainda não esteja totalmente esclarecida, trabalhos onde atuadores piezelétricos, superficies carregadas eletricamente, estudos da influência do pulso elétrico sobre a formação mineral (in vitro), cerâmicas biológicas piezelétricas e introdução de eletrodos (in vivo) estão sendo testados para a promoção de osteogênese e têm apresentado resultados promissores ${ }^{[45,46,47,48,49]}$ 


\subsubsection{Modelo piezelétrico}

A piezeletricidade pode existir para certas simetrias de estruturas cristalinas. Em geral cristais anisotrópicos possuem o efeito piezelétrico e suas constantes piezelétricas podem ser representadas pela matriz $d_{i j}$ :

$$
\left(\begin{array}{llllll}
d_{11} & d_{12} & d_{13} & d_{14} & d_{15} & d_{16} \\
d_{21} & d_{22} & d_{23} & d_{24} & d_{25} & d_{26} \\
d_{31} & d_{32} & d_{33} & d_{34} & d_{35} & d_{36}
\end{array}\right)
$$

Onde $d_{i j}$ são chamados como as constantes de tensão piezelétrica. Sendo que algumas delas são nulas, de acordo com a simetria do material. No caso de biopolímeros naturais, a simetria observada é a $D_{\infty}(\infty 2)$ que mostra somente piezoeletricidade cisalhante. Neste caso $d_{25}=-d_{14}$. No caso do osso, a piezeletricidade aparece somente quando a força de cizalhamento atua nas fibras orientadas de colágeno e então elas passam a deslizar umas nas outras. A piezeletricidade cizalhante é observada na maioria das texturas orientadas de biopolímeros. Para esta simetria o tensor $d_{i j}$ é dado por:

$$
\left(\begin{array}{cccccc}
0 & 0 & 0 & d_{14} & 0 & 0 \\
0 & 0 & 0 & 0 & -d_{14} & 0 \\
0 & 0 & 0 & 0 & 0 & 0
\end{array}\right)
$$

Ela é observada também em filmes orientados de uma grande variedade de filmes sintéticos (entre eles o PVDF) com atividade optica. Para o mesmo grupos de mesma simetria o tensor dielétrico $\varepsilon_{i j}$ é dado por:

$$
\left(\begin{array}{lll}
\varepsilon_{11} & 0 & 0 \\
0 & \varepsilon_{11} & 0 \\
0 & 0 & \varepsilon_{33}
\end{array}\right)
$$

As propriedades piezelétricas, tanto do osso como do PVDF, podem ser estudadas em detalhes em vários trabalhos citados na literatura. ${ }^{[39,42,50,51,52,53]}$ 


\subsubsection{Histomorfometria}

Eriksen ${ }^{[29]}$ cita que a técnica de histomorfometria óssea inclui, além de informações qualitativas sobre toda a estrutura e distribuição de componentes ósseos fornecido pela histologia óssea, a medida de componentes morfológicos, tais como espessura osteóide e espessura da parede óssea. Estas variáveis estatísticas são medidas diretamente. Esta técnica pode também estimar variáveis cinéticas através da utilização de marcações fluorescentes administradas a certos intervalos, que se integram ao osso que está se formando. Entre eles pode-se citar a tetraciclina, alizarina, calceina, xilenol laranja. As distâncias entre cada marcação fornecem informações sobre a taxa de formação e, por derivação, sobre outros processos metabólicos do osso.

Segundo Russo ${ }^{[54]}$, a histomorfometria é o método capaz de fornecer um acesso direto e preciso de análise da atividade celular e dos mecanismos teciduais de remodelação envolvidos na fisiopatologia óssea, principalmente da osteoporose, e na resposta adequada da massa óssea à terapêutica instituída.

Nas últimas três décadas, o campo da histomorfometria progrediu acentuadamente, tendo o seu uso relacionado com a osteoporose nos seguintes aspectos:

a) - Para o diagnóstico de exclusão da osteomalacia e acesso ao turnover ósseo;

b) - Na avaliação e diferenciação dos complexos mecanismos envolvidos na perda da massa óssea das síndromes osteoporóticas;

c) - Para o diagnóstico do efeito do tratamento na remodelação óssea ao se utilizar tanto drogas anti-reabsortivas quanto as que promovem formação óssea. Esta é atualmente uma importante utilização da histomorfometria em estudos experimentais com animais e humanos (indispensável para aceitação de novos medicamentos por órgãos públicos de controle como o FDA);

4 - Dar um acesso à qualidade do osso, como a microarquitetura, particularmente da rede trabecular, da textura da matriz osteóide e da presença de defeitos na mineralização tanto da superficie quanto do interstício.

É fundamental que a análise do material seja processada sem descalcificação prévia

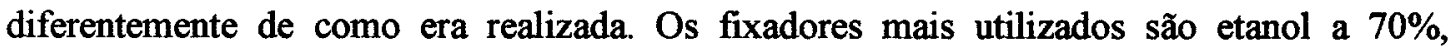
metanol absoluto ou formalina a $10 \%$ com $\mathrm{pH} 7,0$.

Como citado, um dos marcadores mais usados é o antibiótico tetraciclina, devido as suas características de se ligar ao osso neoformado e de emitir fluorescência. É utilizado antes da realização da biópsia (ou no caso de pesquisas envolvendo animais, antes da prática da eutanásia) em doses calculadas oral ou subcutâneo, dependendo de cada caso, por dois dias consecutivos, com intervalo de 10 a 20 dias sem medicação e novamente mais dois dias 
seguidos. Os dois dias já são suficientes para causar o aparecimento de uma fina camada amarela fluorescente que representa o osso recém-formado. Ao se reavaliar com 10 a 14 dias, à distância entre duas linhas fluorescentes nos proporcionam uma idéia da taxa de mineralização. A ausência das margens de tetraciclina denota déficit de neoformação óssea. [54,55,56,57] Na Figura 3.8 abaixo pode ser vista a marcação com tetraciclina observada em microscopia de fluorescência.

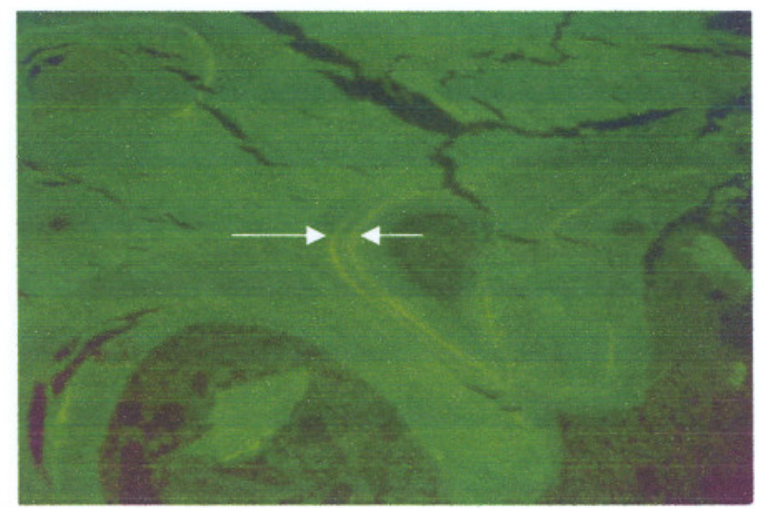

Figura 3.8 - Frente de mineralização óssea marcada com tetraciclina. Repare a dupla marcação (setas brancas), local onde as medidas histomorfométricas são realizadas. (com autorização da Dr $^{\mathrm{a}}$ Vanda Jorgetti - Laboratório de Fisiopatologia Renal FMUSP).

Métodos totalmente ou semi-automatizados, utilizando programas informatizados de análise e imagem das amostras, reduziram o tempo de resultado do exame. Parâmetros estatísticos têm sido utilizados por estes programas para auxiliar no resultado do exame. Os principais seriam: Expressando quantidade, tem-se o Volume de Osso Trabecular (ou Densidade Volumétrica de Osso Trabecular), que significa o percentual de tecido ósseo presente entre os envelopes subcorticais; o Volume Total de Osso, que representa o percentual de osso cilíndrico da biópsia entre periósteos, incluindo córtices e osso esponjoso e a Espessura de Cortical, expressa em micrômetro de osso cortical. Expressando a qualidade do osso, tem-se a Espessura das Trabéculas, dos Nodos Terminais e o Volume Estrela, outro índice global relacionado com conectividade do osso. Estuda-se ainda através da histomorfometria parâmetros de formação como Volume Osteóide, Superfície Osteóide e Espessura Osteóide; além da Taxa de Aposição de Mineralização e Superfície de Mineralização. Como parâmetros da reabsorção, observa-se o Número de Osteoclastos e a Superfície de Erosão (expressada em percentual). ${ }^{[58,59]}$

Pesquisas em animais, usando esse método, também têm sido bastante utilizadas, devido às informações que o osso pode fornecer quando recebe um implante de algum material que se queira testar como biomaterial. ${ }^{[56,57]}$ 


\subsection{Ensaios de Biocompatibilidade: Testes de Citotoxicidade, Sensibilidade Intracutânea e Toxicidade Sistêmica.}

\subsubsection{Preparação das amostras}

As Normas Técnicas ISO 10993-10 annex $B{ }^{[61]}$, ISO 10993-12 [62], ASTM F619 ${ }^{[63]}$ e U.S Pharmacopeia ${ }^{[64]}$, preconizam a seleção e a preparação de amostras e extratos. Se o material ou dispositivo já é encontrado no mercado, os itens de teste devem ser representativos da produção em massa. Se os materiais ou dispositivos estão desenvolvimento, as amostras devem possuir as mesmas características daqueles destinados à produção.

Os potenciais tóxicos de materiais e dispositivos dependem basicamente de sua capacidade de sofrer lixiviação e da toxidade de seus componentes solúveis. Por isso normalmente se utilizam extratos confeccionados desses materiais para a realização dos testes. Contudo, levando em conta certas aplicações, pode ser necessário a utilização do material em condições normais de uso, na forma de um fragmento ou mesmo o próprio dispositivo dentro do teste.

Os meios de extração devem ser constituídos de alguns líquidos com graus de polaridade diferentes, para que se possa atingir diferentes graus de solubilidade dos componentes de um determinado material. Geralmente, os meios de extração mais utilizados para a realização dos testes podem ser resumidos em salina fisiológica, óleos vegetais (óleo de coco, sementes de algodão, sésamo, girassol entre outros), sulfóxido de metila, polietileno glicol e etanol, para o teste de citotoxicidade in vitro, geralmente utiliza-se de meios de culturas completos.

Quanto à temperatura, várias são as possibilidades para a confecção dos extratos. Porém as altas temperaturas podem alterar propriedades, físicas, mecânicas ou químicas de certos compostos. É recomendável, portanto, na maioria das vezes, o trabalho a temperatura similar a do corpo humano (em torno de $36,5^{\circ} \mathrm{C}$ ), seguindo o tempo especificado pela norma para esta temperatura (para a Norma ISO, 72 horas).

Outro fator importante é a proporção estabelecida entre espessura da amostra, área superficial que entrará em contato com a solução e quantidade de material a ser extraído. As normas técnicas ditam procedimentos particulares para cada tipo ou condição de amostra. 


\subsubsection{Teste de citotoxicidade}

O teste de citotoxicidade tem como objetivo detectar o potencial de um material ou dispositivo em produzir efeitos letais ou subletais no sistema biológico a nível celular. Este teste deve ser aplicado a todas as categorias de biomateriais.

Existem três possibilidades para o teste de citotoxicidade: o teste por eluição, o teste por contato direto e o teste por difusão em ágar (detalhado nas Normas ISO 10993-5 e ASTM F895), realizados geralmente com a linhagem ATCC, CCL1 NCTC clone 929 - clone da linhagem $L$, tecido conjuntivo de camundongo, designado $L-929$ - que são cultivadas na forma de monocamada confluente. No teste de eluição, extrato do material é adicionado em concentrações variadas em células em cultura. A avaliação, em geral, é realizada através da observação da inibição ou não do crescimento das culturas celulares. No teste por contato direto, uma determinada quantia do material é colocada diretamente sobre uma monocamada de cultura de células recoberta por meio de cultura. A liberação de substâncias tóxicas pelo material pode lesar as células ou reduzir a taxa o crescimento celular da cultura. No método por difusão em agar, uma quantidade do material sob teste é acondicionada sobre uma camada de agar que recobre uma monocamada confluente de células. Caso substâncias tóxicas sejam liberadas pelo material, estas se difundem através da fina camada de agar, provocando lise e até a morte das células.

O teste de citotoxicidade é um teste rápido, padronizado, sensível e de baixo custo, capaz de fornecer dados se um material apresenta quantidades significantes de elementos tóxicos extraíveis. A sensibilidade do teste está no fato de que as culturas celulares permanecem em ambiente controlado e sem a presença dos mecanismos de defesa celular existente no sistema biológico.

Existe uma correlação bastante razoável entre os teste de curta duração in vivo e os testes de citotoxicidade para materiais implantáveis. Porém estes últimos são apenas indicadores primários de biocompatibilidade biológica e não eliminam a necessidade dos testes in vivo, formulados para interações específicas. 


\subsubsection{Teste de sensibilidade intracutânea}

As normas ISO $10993-10^{[61]}$, ISO $10993-12^{[62]}$, ASTM F719 ${ }^{[67]}$ e ASTM F749 ${ }^{[68]}$ tratam dos testes para a observação de sensibilização e irritação do sistema biológica, caracterizada pela dermatite de contato, que é a reação cutânea mediada pelo sistema imunológico. Essa reação cutânea é causada pelo efeito direto de uma substância sobre a pele. Nos animais de laboratório são observadas reações que vão desde a vermelhidão (eritema) à inflamação (edema). Esses resultados de sensibilização podem fornecer indicativos importantes. Por exemplo, para reação positiva, a substância pode ser caracterizada como lesiva (embora resultados em animais muitas vezes atribuem potencial de risco mais alto que o real) e para reação negativa, pode-se concluir que o material possui uma margem segura em termos de risco potencial para uso em humanos. A irritação pode ser avaliada através de testes de irritação ocular, de pele (primário) e intracutâneo, sendo este último utilizado a mais de trinta anos para testes de polímeros utilizados como recipientes farmacêuticos. $O$ teste consiste na preparação de extratos dos materiais, que são injetados por via intracutanea, em pequenos volumes do dorso de animais de laboratório devidamente tricotomizados (geralmente coelhos albinos). Nos testes, os extratos que apresentarem resposta irritante maior que os controles são considerados tóxicos. Os veículos de extração mais utilizados são solução salina, solução salina/álcool e óleo vegetal oficinal (geralmente óleo de semente de algodão ou de gergelim). A solução fisiológica e o óleo vegetal são importantes veículos de extração, pois eles determinam a propriedade do material em ser hidrossolúvel ou lipossolúvel (o que determina a liberação de íons ou detritos), ou nem um, nem outro, que é um dos indícios que se deseja para o material em teste ser considerado biocompativel (logicamente existem níveis de dissolução que são mínimos e, portanto, aceitáveis).

Os sítios de aplicação dos extratos são observados durante 72 horas e classificados em função da formação de edemas ou eritemas. 


\subsubsection{Feste de toxicidade sistêmica}

O teste de toxicidade sistêmica aguda, determinado pelas normas $I S O 10993-11^{[69]} \mathrm{e}$ ASTM F750 ${ }^{1701}$, consistem no efeito adverso, dentro de um curto espaço de tempo, causado por uma substância administrada em uma única dose. A toxicidade sistêmica está relacionada com os efeitos que componentes químicos, liberados por um material, podem ter sobre o comportamento, a saúde geral e certos órgãos-vitais (figado, cérebro, coração, rins), geralmente distantes do sítio de contato. A normas não fornecem um protocolo detalhado para o estudo da toxicidade sistêmica, sugerindo várias metodologias publicadas em outras normas internacionais Os animais mais utilizados para os teste de toxicidade sistêmica são os camundongos albinos, e os extratos (os mesmos citados anteriormente) podendo ser aplicados por via tópica, inalação intravenosa, intraperitonial ou oral. (ratos também são usados em algumas situações). O comportamento dos animais é observado a intervalos préestabelecidos pela norma ISO, que separa os efeitos adversos em agudo, subagudo, subcrônico e crônico. Os efeitos agudos ocorrem dentro das primeiras 24 horas após a aplicação; efeitos subagudos surgem entre 14 e 28 dias após a aplicação. Estudos que se prolongam entre 90 dias ou até $10 \%$ do tempo de vida do animal são classificados como subcrônico e os crônicos se estendem por um tempo maior que $10 \%$ da vida do animal.

Para o teste de toxicidade sistêmica, os extratos mais comumente utilizados são salina fisiolögica e óleos vegetais (exemplos jấ citados), que representam os componentes extraíveis hidrossolúveis e lipossolúveis respectivamente (podendo, em alguma vezes, ser utilizado também soluções intermediárias, como é o caso do Etanol/Salina Fisiológica 1/20 $\mathrm{v} / \mathrm{v})$.

Os resultados do teste são baseados na observação do comportamento dos animais a intervalos pré-determinados durante três dias após o extrato administrado. A interpretação desses resultados baseia-se nas diferenças apresentadas entre os grupos de testes e os controles (os controles são apenas as soluçães submetidas aos mesmos processos que os extratos). 


\section{Materiais e Métodos}

\subsection{Aspectos gerais}

Neste trabalho foram utilizadas amostras de PVDF $\beta$ com $12 \mu \mathrm{m}$ de espessura, estirada biaxialmente. A cristalinidade é de aproximadamente $42 \%$, e a razão entre as fases $\beta$ e $\alpha$ é de $45 \%$ (dados obtidos de amostras virgens). 0 polímero, fabricado pela Empresa Kureha Chemical Industries, biaxialmente estirado e comercialmente utilizado nas indústrias de capacitores, foi doado e previamente polarizado pelo Grupo de Polímeros Bernhard Gross do Instituto de Física da USP de São Carlos.

Como a intenção deste trabalho é a observação de algumas reações do polímero em contato com o osso in vivo (protocolo de pesquisa aprovado pela Comissão de Ética para análise de Projetos de Pesquisa do Hospital das Clínicas da Faculdade de Medicina da Universidade de São Paulo - Anexo A), fez-se ṇecessário a prática de intervenções cirúrgicas para implantes. Porém, qualquer material que venha a ser utilizado como implante necessita ser testado em vários aspectos. As normas ASTM, ISO $10993^{[71]}$ e US Pharmacopeia ${ }^{[64]}$ apresentam um conjunto de procedimentos técnicos que ditam o que se deve fazer para testar um determinado material candidato a biomaterial. Além disso, para esses ensaios, assim como para o implante, o material necessita ser submetido e resistir a pelo menos um dos vários processo de esterilização existentes. Dessas, duas foram escolhidas por serem as mais utilizadas em polímeros: a esterilização por óxido de etileno $\mathrm{e}$ por radiação, realizadas através do Instituto de Ortopedia e Traumatologia do HC-FMUSP. A esterilização por autoclave ou estufa, muito comum em laboratórios e hospitais, foram descartadas devido a baixa resistência de grande parte dos polimeros quando submetidos a altas temperaturas ${ }^{[3]}$, o que determinaria deformações mecânicas e conseqüente alteração na polarização do PVDF. Portanto, os testes de esterilização se resumiram nos dois tipos mencionados acima e serviram para verificar qual seria a melhor forma de esterilizar o polímero PVDF de tal maneira a preservar suas propriedades mecânicas e piezelétricas.

Para testar a compatibilidade do filme de PVDF frente ao sistema biológico, foram escolhidos três procedimentos: os ensaios de sensibilidade intracutânea, toxicidade sistêmica e citoxicidade. Para os ensaios de toxicidade sistêmica e sensibilidade intracutânea, foram confeccionados extratos com o polímero, seguindo o determinado pelas normas ISO 10993 10 annex $B^{[61]}$, ISO $10993-12^{[62]}$ e ASTM F619. ${ }^{[63]}$

Como para os teste de biocompatibilidade e para o implante de PVDF foram exigidos animais, seguiram-se alguns procedimentos técnicos e normas para a utilização 
tanto coelhos como camundongos, para que se pudesse manter um padrão desejável e dentro de éticas tanto para manuseio, manutenção assim como para a eutanásia dos animais. $[72,73,74,75,76,77,78,79,80]$

As análises dos resultados do provável estímulo do polímero sobre as lesões induzidas nas tíbias de coelho foram baseadas em medidas histomorfométricas e análises morfológicas em lâminas histológicas convencionais.

\subsection{Teste de citotoxicidade}

\subsubsection{O teste}

Dentre as possibilidades de teste para a avaliação da citotoxicidade constantes da norma ISO $10993-5^{[65]}$, foi selecionado o teste por difusão em ágar, que é comum à norma ASTM F895 ${ }^{\text {[69] }}$, onde uma quantidade do material sob teste, no caso o PVDF, é colocada sobre uma camada de ágar que recobre uma monocamada confluente de células. Caso substâncias tóxicas sejam liberadas pelo material, estas se difundem através da camada fina de ágar, matando ou rompendo células da monocamada confluente. Devido a complexidade deste teste e as condições especiais que as culturas celulares exigem, este procedimento foi realizado pela Seção de Culturas Celulares do Instituto Adolfo Lutz de São Paulo, conforme demonstrado no laudo do Anexo B.

\subsubsection{O modelo biológico para o ensaio}

Para este ensaio, células NCTC Clone 929 de tecido conjuntivo de camundongo (CCL1-ATCC-USA), foram semeadas em placas de Petri, estéreis e descartáveis (Corning) em MME Eagle e incubadas em estufa (Forma) a $37 \pm 1{ }^{\circ} \mathrm{C}$, com atmosfera controlada (5\% de $\mathrm{CO}_{2}$ e $95 \%$ de umidade) durante 48 horas. $\mathrm{O}$ meio de cultura líquido foi, então, substituído por um meio de cobertura sólido, composto de partes iguais de meio de cultura concentrado ( $2 x)$ e ágar com vermelho neutro.

\subsubsection{Procedimento}

Seguindo a etapa acima, as amostras de PVDF $(0,5 \mathrm{~cm} \mathrm{x} 0,5 \mathrm{~cm})$ foram colocadas sobre o meio de cobertura, com o auxilio de cilindros de $0,5 \mathrm{~cm}$ de diâmetro. As placas de Petri voltaram a ser incubadas por um periodo adicional de 24 horas. Como controle positivo 
foi utilizado um fragmento de $0,5 \mathrm{~cm} \times 0,5 \mathrm{~cm}$ de látex tóxico e como controle negativo discos de papel filtro atóxico de $0,5 \mathrm{~cm}$ de diâmetro.

\subsubsection{Avaliação dos resultados}

A avaliação dos resultados do teste de citotoxicidade é feita pela observação do índice de zona, que é representada pela área não corada pelo corante vital, e anotando-se o índice de lise, que indica a porcentagem de células degeneradas.

Os índices, apresentados na Tabela 4.1, são traduzidos numericamente $\mathrm{e}$ correlacionados, fornecendo o índice de resposta. As amostras são testadas e quadruplicadas em placas separadas.

Tabela 4.1 - Indice de zona e índice de lise utilizados na avaliação da citotoxicidade (adaptado ${ }^{[651}$ ).

\begin{tabular}{cccc}
\hline $\begin{array}{c}\text { Indice de } \\
\text { zona }\end{array}$ & Descrição & $\begin{array}{c}\text { Indice } \\
\text { de lise }\end{array}$ & Descrição \\
\hline 0 & nenhuma zona sob e ao redor da mostra & 0 & nenhuma lise \\
1 & zona limitada sob a amostra & 1 & menos que $20 \%$ da zona afetada \\
2 & zona menor que $0,5 \mathrm{~cm}$ ao redor da amostra & 2 & menos que $60 \%$ da zona afetada \\
3 & zona entre 0,5 e $1,0 \mathrm{~cm}$ ao redor da amostra & 3 & menos que 80\% da zona afetada \\
4 & zona maior que 1,0 cm sem envolver toda placa & 4 & mais que 80\% da zona afetada \\
5 & zona que envolve toda placa & 5 &
\end{tabular}

\subsection{Preparo do veículo de extração: Testes de Sensibilidade Intracutânea e Toxicidade Sistêmica}

\subsubsection{Veículos de extração ou solventes}

Foram utilizadas as seguintes soluções (veículos de extração) para a confecção dos extratos/controles:

- Veículo de Extração Polar (VEP) - soro fisiológico (estéril);

- Veículo de Extração Não-Polar (VEN) - óleo vegetal de semente de sésamo (gergelim), submetido a sistema de filtragem (filtro de $0,45 \mu \mathrm{m}$ estéril);

- Veículo de Extração Intermediário (VEI) - etanol:soro fisiológico (1:20) (etanol P.A.) 


\subsubsection{Polímero (amostra)}

Foram separadas 6 amostras de filme de PVDF $\beta$ com $12 \mu \mathrm{m}$ de espessura cada. Por se tratar de um filme fino, seguiu-se a razão área/veiculo de extração $\left(6 \mathrm{~cm}^{2} / \mathrm{ml}\right)$, mostrado na Tabela 4.2, para chegar aos $120 \mathrm{~cm}^{2}(12 \mathrm{~cm} \times 10 \mathrm{~cm})$ de área necessários para os $20 \mathrm{ml}$ de veículo de extração utilizados.

Os filmes foram esterilizados em óxido de etileno.

Tabela 4.2 - Relação entre espessura do filme e razão área/quantidade de veículo de extração (adaptado ${ }^{[62,63\}}$.

\begin{tabular}{c|cc}
$\begin{array}{c}\text { Forma do } \\
\text { material (área) }\end{array}$ & $\begin{array}{c}\text { Espessura } \\
(\mathbf{m m})\end{array}$ & $\begin{array}{c}\text { Razão área/veículo de } \\
\text { extração }\end{array}$ \\
\hline $\begin{array}{c}\text { Filme ou } \\
\text { lâmina fina }\end{array}$ & $<0,5$ & $6 \mathrm{~cm}^{2} / 1 \mathrm{ml}$ \\
& $0,5 \mathrm{a} 1,0$ & $3 \mathrm{~cm}^{2} / 1 \mathrm{ml}$ \\
\hline
\end{tabular}

\subsubsection{Preparação dos extratos e controles}

Para cada 20ml de veículo de extração, utilizou-se uma das amostras de PVDF de $120 \mathrm{~cm}^{2}$. Dentro de uma capela de fluxo laminar, em ambiente desinfetado e com as soluções, instrumentos e recipientes esterilizados, cortou-se o polímero em tiras para se obter uma área maior de contato entre amostra e solução. As amostras foram colocadas em três frascos e, em seguida, adicionados os $20 \mathrm{ml}$ dos veículos de extração - salina fisiológica, solução de etanol:salina fisiológica e óleo vegetal respectivamente. Ao mesmo tempo, preparou-se um "branco" para cada meio, (três frascos somente com as soluções citadas) para comparação e administração paralela. Então, os frascos contendo os veículos com e sem as amostras de polímero foram condicionados a $37^{\circ} \mathrm{C}\left( \pm 2{ }^{\circ} \mathrm{C}\right)$ por 72 horas $( \pm 2 \mathrm{~h})$, com agitação constante (agitador C24 Incubator Shaker - New Brunswick Scientific). Após este periodo, os extratos foram vertidos em frascos tipo garrafa, estéreis, para separar o polímero dos veículos de extração e estes pudessem ser armazenados até o momento de utilização. Esse procedimento também foi realizado dentro da capela de fluxo laminar em ambiente limpo. Desta forma, com as soluções de salina fisiológica, etanol:salina e óleo vegetal, mais PVDF, obteve-se, respectivamente, os Extratos Polar (EP), Intermediário (EI) e Não-Polar (EN). Em contrapartida, as soluções sem o polimero forneceram os Controles Polar (CP), Intermediário (CI) e Não-Polar (CN). 


\subsection{Teste de sensibilidade intracutânea}

\subsubsection{Oteste}

Este teste, ditado pelas Normas ASTM F719, ASTM F749 e ISO 10993, partes 10 e 12 , têm como princípio determinar o potencial, do polímero em teste, de produzir irritação após a inoculação intradérmica dos extratos e dos controles na pele da região dorsal de coelhos. O material é excluído automaticamente do teste quando este se mostra irritante para a pele, olhos ou mucosa e/ou possua $\mathrm{pH} \leq 2$ ou $\mathrm{pH} \geq 11,5$, o que não é o caso do PVDF.

\subsubsection{Os animais}

Foram utilizados cinco coelhos da raça New Zealand White, machos, jovens, com peso corpóreo de aproximadamente $2,5 \mathrm{Kg}$, fornecidos pelo Biotério Central da FMUSP, aclimatados e alimentados com ração balanceada e água ad libitum, mantidos e manuseados no Biotério do Instituto de Ortopedia e Traumatologia do HC-FMUSP.

\subsubsection{Procedimento de inoculação}

Um dia antes do teste, foi realizada a tricotomia da região dorsal dos animais, nos dois lados da coluna, seguindo uma área suficiente para que as injeções de extratos pudessem ser realizadas (Figura 4.1). Os animais receberam identificações A1, A2, A3, A4 e A5.

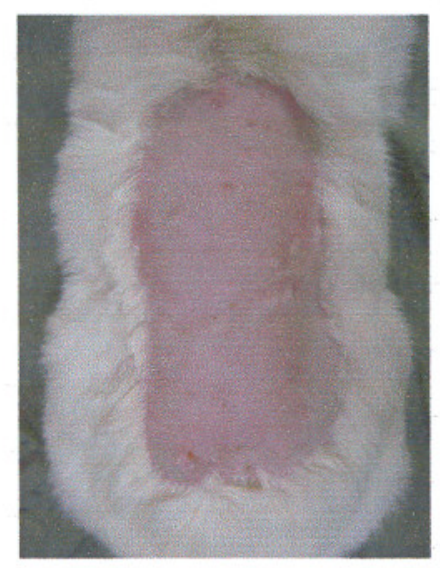

Figura 4.1 - Tricotomia na região dorsal do coelho.

Imaginariamente, dividiu-se o dorso tricotomizado do animal em quatro quadrantes, no qual foi injetado, intracutaneamente, $1 \mathrm{ml}$ de Extrato Polar (EP) em cinco pontos no quadrante superior esquerdo $(0,2 \mathrm{ml}$ por aplicação) e similarmente, $1 \mathrm{ml}$ de Controle Polar (CP) em cinco pontos no quadrante logo abaixo (seguindo a medida de $0,2 \mathrm{ml}$ por aplicação). 
Repetiu-se o procedimento para o Extrato Não-Polar (EN) e para o Controle Não-Polar (CN) nos outros quadrantes do outro lado da coluna do mesmo animal. Todo o procedimento descrito acima foi realizado nos demais animais. Um esquema é demonstrado na Figura 4.2. Usaram-se, para as injeções intradérmicas, agulhas de tamanhos e calibres apropriados para a viscosidade dos extratos em teste.

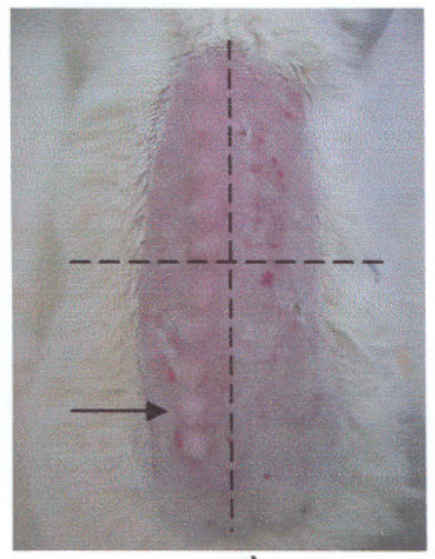

a)

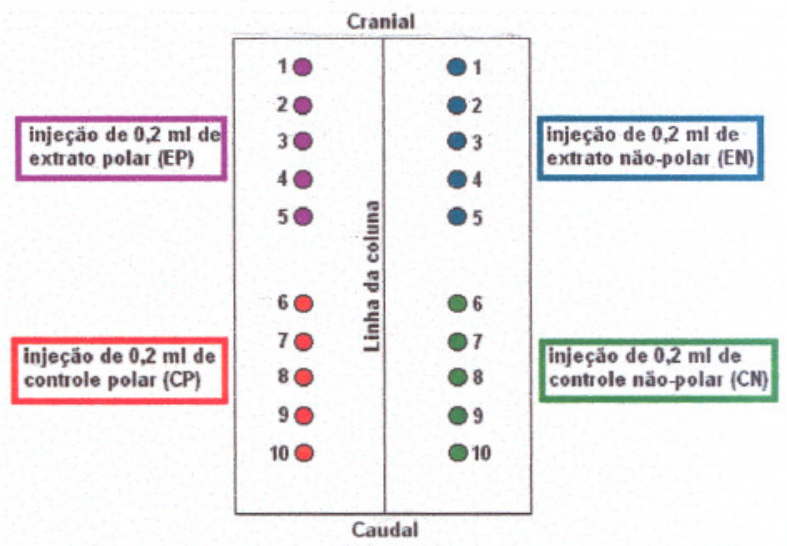

b)

Figura 4.2 - Aplicação dos extratos e controles polares para teste de sensibilidade intracutânea. a) Demonstração dos quadrantes e visualização após aplicação intracutânea (seta); b) Locais de aplicação.

\subsubsection{Observação dos animais: formação de edemas e eritemas}

Foram observados nos animais as aparências das reações teciduais de cada ponto de injeção em tempos pré-determinados de $0,1,24,48$ e 72 horas. A reação do tecido é graduada por eritema e edema, de acordo com o sistema de classificação apresentado na Tabela 4.3, para cada injeção realizada e a cada intervalo de tempo observado. Os resultados são registrados em uma planilha montada conforme demonstra a Tabela 10.1 do Anexo C.

Tabela 4.3 - Possíveis reações causadas pelos extratos e controles aplicados intradermicamente (adaptada $^{[61,62,67,68]}$ ).

\begin{tabular}{l|c}
\hline \multicolumn{1}{c|}{ Reação } & Nível numérico \\
\hline \multicolumn{1}{c|}{ Eritema e formação de escara } \\
Sem eritema & 0 \\
Muito leve (pouco perceptível) & 1 \\
Definido $\quad$ Edema & 2 \\
Moderado & 3 \\
Severo (vermelho-beterraba ou formaço de escara antes do eritema). & 4 \\
\hline & \\
Sem edema & 0 \\
Leve (pouco perceptível) & 1 \\
Definido (extremidades da área bem definidas por aumento) & 2 \\
Moderado (aumento de aproximadamente 1 mm) & 3 \\
Severo (aumento > lmm, estendendo além da área de exposição). & 4 \\
\hline Contagem possível para a irritação & $\mathbf{8}$ \\
\hline
\end{tabular}




\subsubsection{Avaliação dos resultados}

Determina-se o Índice de Irritação Primária (IIP).

Para cada animal, somam-se as contagens de irritação primária do eritema e edema juntos, mas separadamente para cada extrato-teste a cada tempo especifico. Divide-se essa soma pelo número total de observações (usam-se somente observações de 24, 48 e 72 horas para os cálculos). A determinação é similar para os locais injetados com o controle (branco).

Subtrai-se a contagem obtida dos reagentes controles da contagem obtida com os extratos do material. O resultado é a Contagem de Irritação Primária (CIP). Um exemplo montado na Tabela 10.2 do Anexo $\mathrm{C}$ demonstra, apenas para uma melhor compreensão, o cálculo para um animal testado hipoteticamente, denominado $\mathbf{C 1}$.

Tem-se então, para o coelho-exemplo $\mathrm{Cl}$ acima citado, o valor de $\mathbf{C I P}=\mathbf{0 , 8 7}$ e, supondo outros quatro animais como exemplo $(C 2=1,03 ; C 3=0,95 ; C 4=1,25 ;$ C5 $=\mathbf{0 , 8 3}$ ), pode-se obter o Índice de Irritação Primária, somando-se as contagens dos animais e dividindo pelo número de animas. Portanto tem-se:

IIP $=(\mathrm{Cl}+\mathrm{C} 2+\mathrm{C} 3+\mathrm{C} 4+\mathrm{C} 5): 5=4,93: 5=0,986$

O valor de IIP acima corresponde a uma resposta de irritação LEVE, conforme o Índice de Irritação Primária caracterizado pelo número descrito na Tabela 4.4 abaixo:

Tabela 4.4 - Índices de Irritação Primária (adaptada ${ }^{[61,62,67,687}$ ).

\begin{tabular}{l|c}
\hline \multicolumn{1}{c|}{ Resposta por categoria } & Contagem média (IIP)* \\
\hline NEGLIGENCIAVEL & 0 a 0,4 \\
LEVE & 0,5 a 1,9 \\
MODERADO & 2,0 a 4,9 \\
SEVERO & 5 a 8 \\
\hline * O índice de Irritação Primária é determinado pela soma das \\
Contagens de Irritaçăo Primánia para cada animal e dividido \\
\multicolumn{2}{c}{ pelo número de animais. }
\end{tabular}




\subsection{Teste de toxicidade sistêmica}

\subsubsection{O teste}

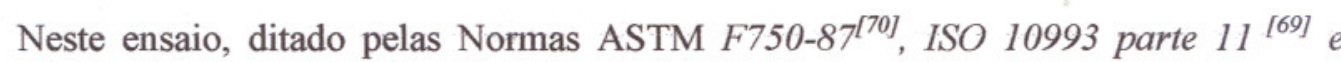
Pharmacopeia of United States of América (1995) - Biological Reactivity Tests, in vivo ${ }^{[64]}$, tem-se como princípio determinar o potencial de toxicidade sistêmica do polímero em teste após a inoculação intraperitonial ou intravenosa dos extratos e dos controles em camundongos, comparando reações adversas que estes possam a vir apresentar.

\subsubsection{Os animais}

Segundo as Normas Técnicas, os ensaios devem ser realizados em camundongos albinos da raça Swiss, com peso entre $17 \mathrm{~g}$ e $23 \mathrm{~g}$, porém, os animais usados nesse ensaio variaram entre 35 e 55 gramas, o que fez com que cuidados necessários fossem tomados para respeitar a dosagem recomendada pela norma $(50 \mathrm{ml} / \mathrm{kg})$.

Ao todo foram 30 animais, obtidos do Biotério Central da Faculdade de Medicina de São Paulo e mantidos no Biotério do Instituto de Ortopedia e Traumatologia do HC-FMUSP, sendo tratados com alimentação balanceada e água filtrada. Foram separados em 6 grupos de 5 animais para aplicação dos extratos e controles, conforme detalhado na Tabela 4.5 , abaixo.

Tabela 4.5 - Grupos para separação dos animais de teste

\begin{tabular}{|c|c|c|c|c|c|}
\hline Grupo 1 & Grupo 2 & Grupo 3 & Grupo 4 & Grupo 5 & Grupo 6 \\
\hline $\begin{array}{c}\text { Extrato } \\
\text { Polar } \\
\text { (EP) }\end{array}$ & $\begin{array}{l}\text { Controle } \\
\text { Polar } \\
\text { (CP) }\end{array}$ & $\begin{array}{c}\text { Extrato } \\
\text { intermediário } \\
\text { (EI) }\end{array}$ & $\begin{array}{l}\text { Controle } \\
\text { intermediário } \\
\text { (CD) }\end{array}$ & $\begin{array}{l}\text { Extrato Não } \\
\text { Polar } \\
\text { (EN) }\end{array}$ & $\begin{array}{c}\text { Controle Não } \\
\text { Polar } \\
\text { (CN) }\end{array}$ \\
\hline 5 animais & 5 animais & 5 animais & 5 animais & 5 animais & 5 animais \\
\hline $\begin{array}{c}\text { Salina } \\
\text { fisiológica } \\
+ \\
\text { PVDF }\end{array}$ & $\begin{array}{l}\text { Salina } \\
\text { fisiológica }\end{array}$ & $\begin{array}{c}\text { Etano:Salina } \\
\text { fisiológica } \\
+ \\
\text { PVDF }\end{array}$ & $\begin{array}{l}\text { Etanol:Salina } \\
\text { fisiológica }\end{array}$ & $\begin{array}{c}\text { Ólco } \\
\text { Vegetal } \\
+ \\
\text { PVDF }\end{array}$ & $\begin{array}{l}\text { Óleo } \\
\text { vegetal }\end{array}$ \\
\hline
\end{tabular}

\subsubsection{Procedimento de inoculação}

Foram feitas as tricotomias e as identificações dos animais na véspera do experimento (Figura 4.3a). Seguiu-se com a aplicação dos extratos e controles através de injeção intraperitonial, na dose $50 \mathrm{ml} / \mathrm{kg}$ de peso corpóreo do animal (em média 1,5 $\mathrm{ml} /$ camundongo) (Figura 4.3b). 


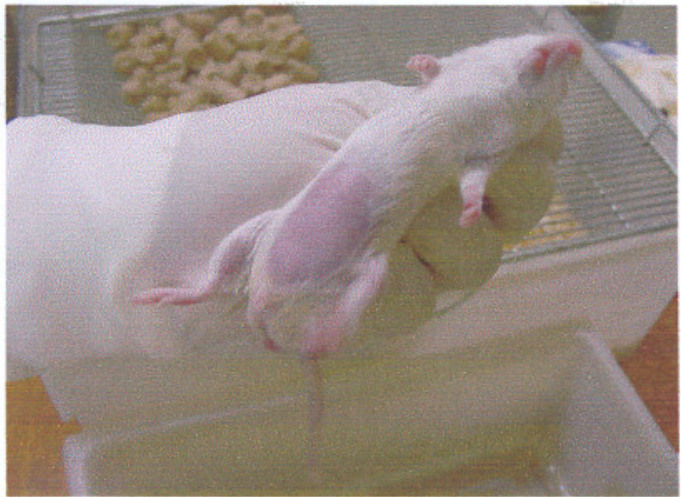

a)

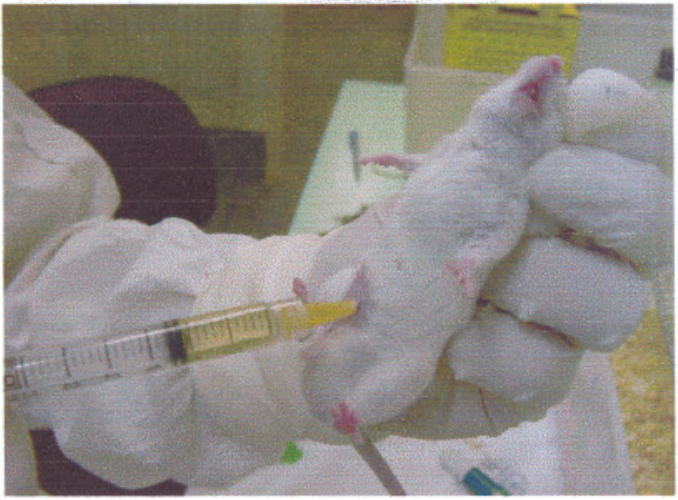

b)

Figura 4.3 - a) Tricotomia na região abdominal do camundongo; b) Aplicação de extrato/veículo de extração na região abdominal (intraperitonial) do camundongo.

\subsubsection{Observação das reações adversas dos animais: coleta de dados}

As observações das reações adversas nos animais foram realizadas nos tempos 0,4 , 24,48 e 72 horas. Os sintomas a serem avaliados são descritos na Tabela 4.6 abaixo:

Tabela 4.6 - Respostas dos ensaios conforme sintomas exibidos pelos animais inoculados com os extratos e os controles para o teste de toxicidade sistêmica. (adaptado ${ }^{[64,69,70]}$ )

\begin{tabular}{l|l|c}
\hline Resposta & \multicolumn{1}{|c|}{ Descrição } & $\begin{array}{c}\text { Índice de } \\
\text { toxicidade } \\
\text { sistêmica }\end{array}$ \\
\hline $\begin{array}{l}\text { Normal } \\
\text { Leve }\end{array}$ & $\begin{array}{l}\text { Animal não exibe sintomas adversos. } \\
\text { Animal exibe sintomas adversos leves, mas notáveis de hipocinesia, dispinéia ou } \\
\text { irritação abdominal. }\end{array}$ & 0 \\
Moderada \\
$\begin{array}{l}\text { Animal exibe evidência definitiva de hipocinesia, dispinéia, irritação abdominal, } \\
\text { ptose ou diarréia (usualmente o peso corpóreo cai entre 15 a 17 gramas). } \\
\text { Snimal exibe prostração, cianose, tremores ou sintomas severos de dispnéia, } \\
\text { irritação abdominal, ptose ou diarréia (perda extrema de peso corpóreo > que 15 } \\
\text { gramas). } \\
\text { Animal morre. }\end{array}$
\end{tabular}

O teste é considerado negativo se nenhum dos animais injetados com os extratos mostrarem uma reação biológica significativamente maior que os animais tratados com o controle.

\subsubsection{Avaliação dos resultados}

Os resultados obtidos são analisados através da comparação de comportamentos entre animais inoculados com material de teste e os inoculados com o controle. As Tabelas 11.1 e 11.2 do Anexo D mostram, respectivamente, os esquemas de uma planilha que pode ser montada para anotações e análise das observações e uma para anotar os valores médios obtidos pelos animais durante os dias de teste.

\footnotetext{
${ }^{4}$ Ptose: queda de um órgão pelo relaxamento dos ligamentos vicerais ou das paredes abdominais.
} 


\subsection{Cirurgia de implante do PVDF em tibias de coelhos}

Para provocar as lesões ósseas padronizadas nas tíbias dos coelhos, foram utilizadas brocas de 2,5 $\mathrm{mm}$. Essas lesões, que posteriormente serão os sítios de análise do crescimento ósseo, entraram em contato com o polímero piezelétrico PVDF através da fixação deste, junto ao osso, em conjunto com uma placa de osteossíntese.

\subsubsection{Os animais e os procedimentos pré-cirúrgicos}

Foram utilizados 20 coelhos da raça New Zealand White, machos, jovens, com peso corpóreo de entre 2,7 e 3,0 $\mathrm{Kg}^{5}$, pelo Biotério Central da Faculdade de Medicina da USP, aclimatados e alimentados com ração balanceada e água ad libitum, mantidos e manuseados no Biotério do Instituto de Ortopedia e Traumatologia do HC-FMUSP.

Como qualquer cirurgia em que se queira manter um ambiente o mais estéril possivel, todo um protocolo foi seguido, desde as vestimentas (uniformes, tocas, luvas, etc.), assepsia (escovas, detergente degermante, P.V.P.I. ${ }^{6}$, etc.) e montagem da mesa cirúrgica (campos, caixa cirúrgica, fios de sutura, bisturi, gazes esterilizados, etc.).

\subsubsection{Material implantado e equipamentos extracaixa cirúrgica}

Para a realização das cirurgias de implante, foram utilizados os filmes de polímero PVDF, comercialmente adquiridos e cortados nas dimensões $25 \mathrm{~mm} \times 7 \mathrm{~mm}$, com 4 furos de 2,5mm cada (Figura 4.4), as placas de osteossintese bucomaxilofacial (25mm x 5mm, com 4 furos de $2,5 \mathrm{~mm}$ cada) e os respectivos parafusos $(6 \mathrm{~mm} \times 2 \mathrm{~mm} \phi)$ (Figura 4.5 ), a chave própria para esses parafusos (Figura 4.6a), perfuradores (microretíficas) e fio (extensão) elétricos, brocas de $1,5 \mathrm{~mm}$ e 2,5 mm e o guia para perfuração (condutor das brocas) (Figura 4.6b);

Deve-se lembrar que todos os materiais, equipamentos e ferramentas citados foram devidamente limpos e esterilizados, alguns por óxido de etileno e outros por autoclave.

\footnotetext{
${ }^{5}$ Peso estipulado devido ao maior diâmetro geralmente apresentado pelas tibias, o que inferia uma maior resistencia à fraturas durante as cirurgias de implante.

${ }^{6}$ P.V.P.I - polivinilpirrolidona-iodo a $10 \%$ - $1 \%$ de iodo ativo em solução aquosa.
} 


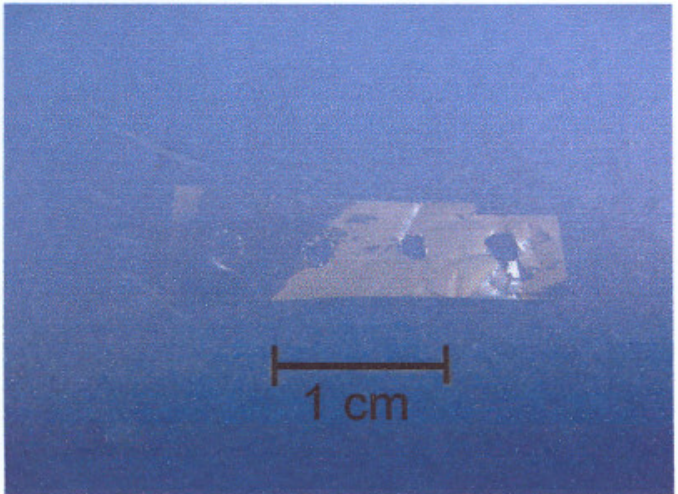

a)

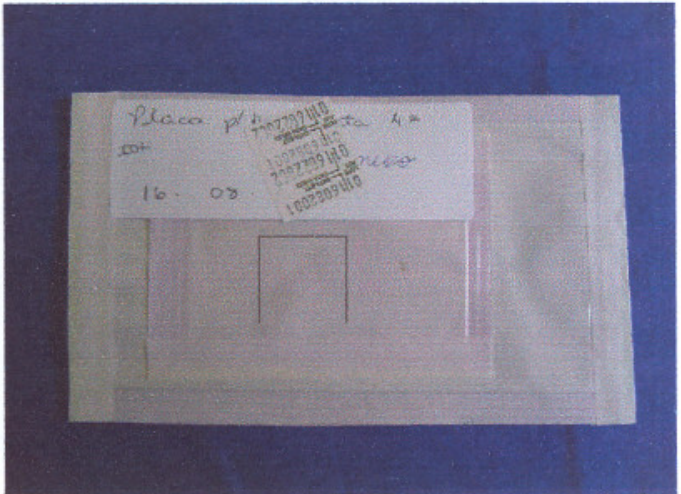

b)

Figura 4.4 - Filme de PVDF polarizado. a) antes de ser submetido ao processo de esterilização por óxido de etileno; b) acondicionado em embalagem dupla e esterilizado (dentro da marcação quadrada).

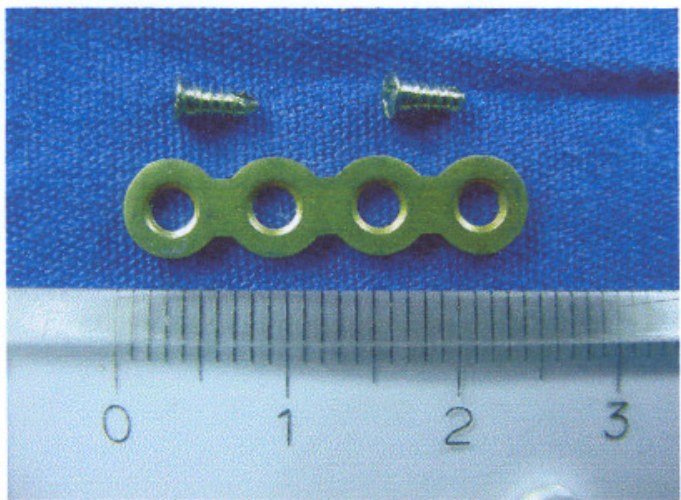

a)

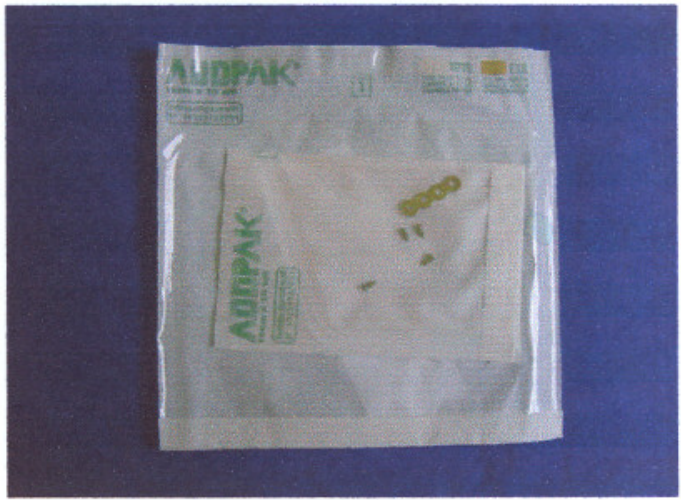

b)

Figura 4.5 - Placa de osteointegração bucomaxilofacial em titânio comercialmente puro e parafusos em Ti6Al-4V utilizados para fixação do PVDF junto à tíbia do coelho. (Fornecidos pela empresa ENGIMPLAN Ind. e Com. Ltda). a) antes de ser submetido ao processo de esterilização por óxido de etileno; b) acondicionado em embalagem dupla e esterilizado.

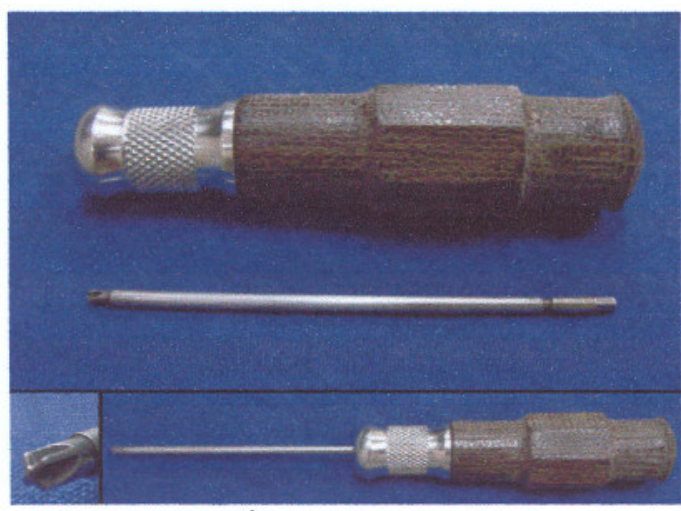

a)

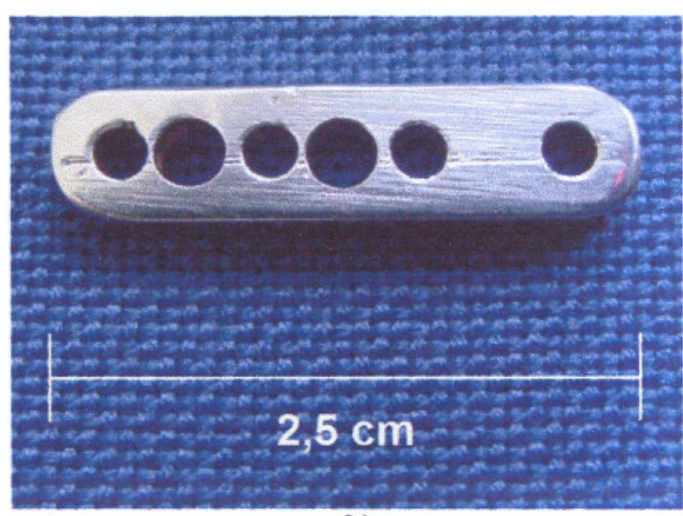

b)

Figura 4.6 - Equipamentos: a) Chave específica para os parafusos da placa bucomaxilofacial. (Fornecida pela empresa ENGIMPLAN Ind. e Com. Ltda) e b) guia para as brocas. 


\subsubsection{Tricotomia e anestesia}

Para a realização das tricotomias, o detergente degermante foi utilizado tanto como uma pré-assepsia, como para a formação da espuma que facilita a raspagem dos pelos. Esta foi realizada com uma lâmina de barbear comum presa a um aparelho.

A associação dos anestésicos cloridrato de quetamina (anestésico dissociativo) e cloridrato de xilazina (miorrelaxante a nível central) foi utilizada para a realização da cirurgia ${ }^{[74,81]}$. Mesmo o animal estando sedado, a xilocaína era aplicada no local das incisões antes destas serem realizadas ${ }^{7}$.

\subsubsection{Técnica cirúrgica}

O coelho foi anestesiado com associação quetamina/xilazina (anestesia geral); é realizada a tricotomia bilateral dos pelos da região da tíbia; preparação da mesa cirúrgica (campos estéreis e instrumentais cirúrgicos) (Figuras 4.7a e 4.7b);

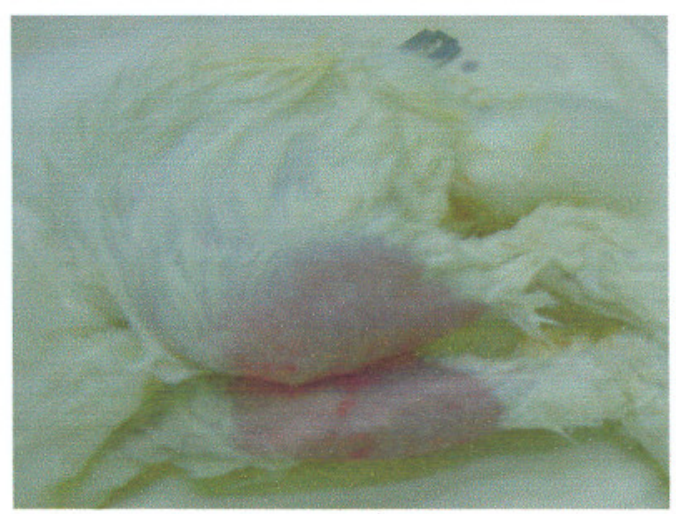

a)

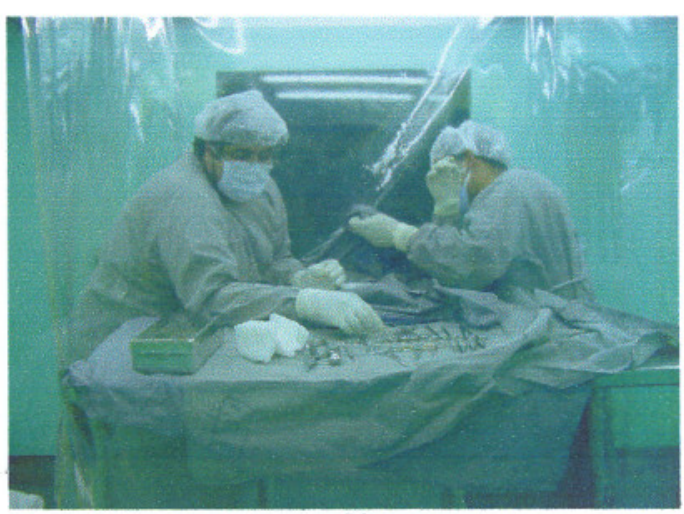

b)

Figura 4.7 - Descrição da técnica cirúrgica: a) animal anestesiado e tricotomia bilateral das tíbias pronta; b) preparação da mesa cirúrgica;

No animal, colocado em decúbito dorsal sobre a canaleta da mesa cirúrgica, foi realizada a anti-sepsia com P.V.P.I.. Foi aplicado xilocaína e realizada incisão na região antero-medial do $1 / 3$ proximal da perna direita, interessando pele e subcutâneo, desde a região metafisária, cerca de $1 \mathrm{~cm}$ distal a interlinha articular do joelho, com extensão aproximada de $4 \mathrm{~cm}$ (Figuras $4.8 \mathrm{a}$ e $4.8 \mathrm{~b}$ );

\footnotetext{
${ }^{7}$ Procedimentos de anestesia, cirurgia e pós-cirúrgicos supervisionados pela médica veterinária Drª Angélica Paula Grando (FMVZUSP) e realizadas pelo médico ortopedista Dr. Raul Bolliger Neto (IOT-HC-FMUSP).
} 


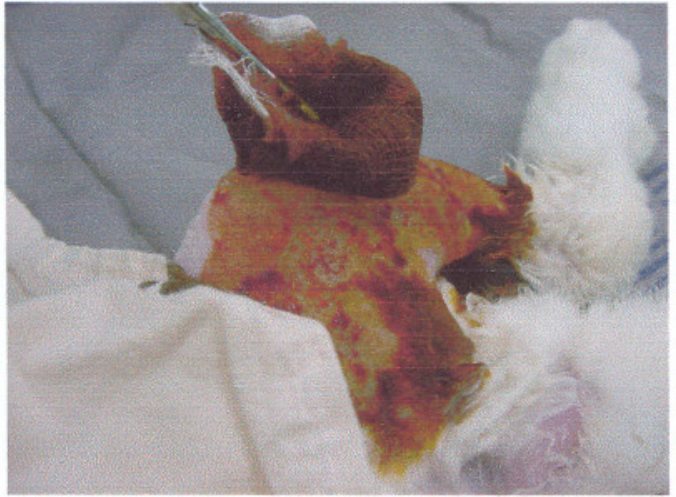

a)

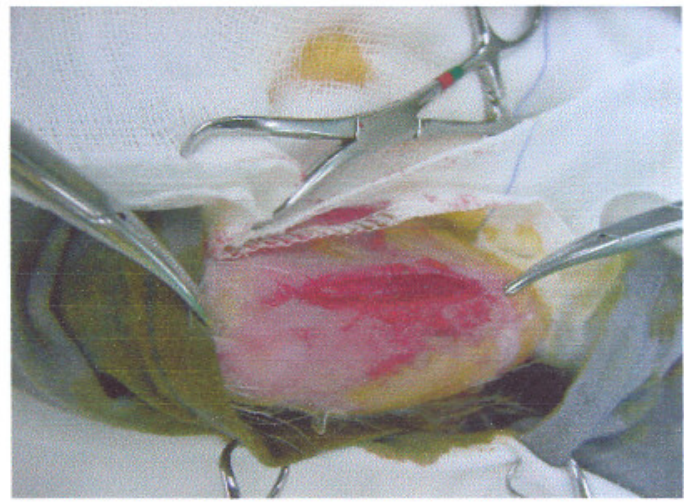

b)

Figura 4.8 - Descrição da técnica cirúrgica: a) anti-sepsia pré-operatória; b) inserção;

Na seqüência, foram feitas a divulsão da fascia profunda e desinsersão do plano muscular junto à borda medial da crista anterior da tíbia, afastando o músculo medialmente, abrindo o periósteo e expondo a tíbia (Figura 4.9a). Prosseguindo, foram feitos quatro furos, utilizando uma broca de $1,5 \mathrm{~mm}$ de diâmetro, motor elétrico (micro-retífica) sob pressão manual e um guia especialmente confeccionado. Estas perfurações atravessaram uma camada cortical apenas aprofundando até o canal medular e serviram para a fixação da placa de osteossíntese e, conseqüentemente, do polímero (Figura 4.9b).

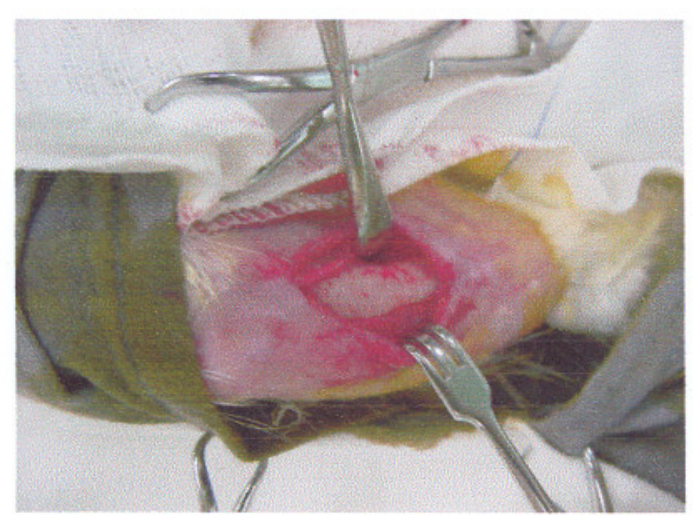

a)

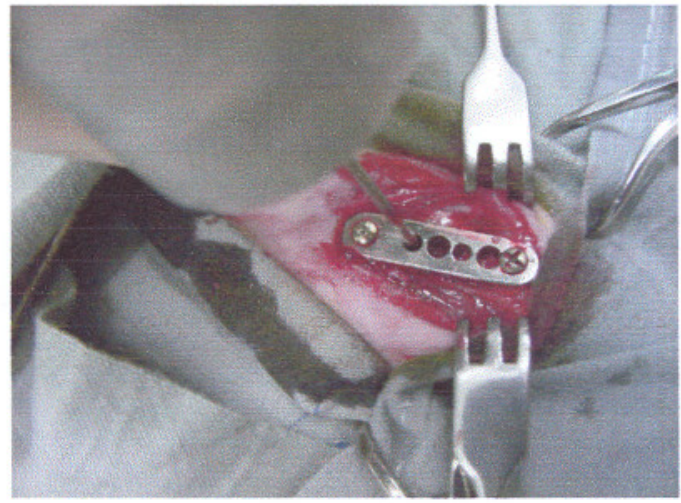

b)

Figura 4.9 - Descrição da técnica cirúrgica: a) exposição da tíbia; b) utilização do guia para a realização das perfurações, na camada cortical da tíbia para fixação da placa e do polímero (broca 1,5 mm de diâmetro);

O passo seguinte consistiu na realização de dois furos utilizando o mesmo motor elétrico e a mesma guia, porém substituindo a broca por uma de $2,5 \mathrm{~mm}$ de diâmetro. Essas lesões, onde mais tarde serão os sítios de análise de crescimento ósseo, foram feitas entre os $1^{\circ}$ e $2^{\circ}$ e entre os $2^{\circ}$ e $3^{\circ}$ furos citados no parágrafo anterior, também com espessura de uma camada cortical (Figura 4.10). 


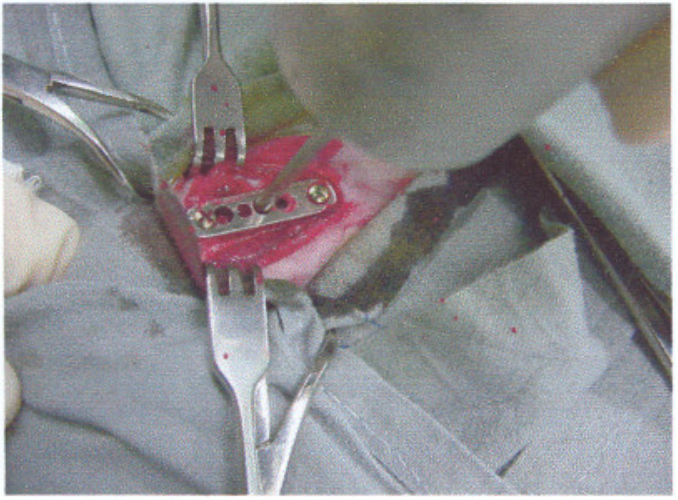

a)

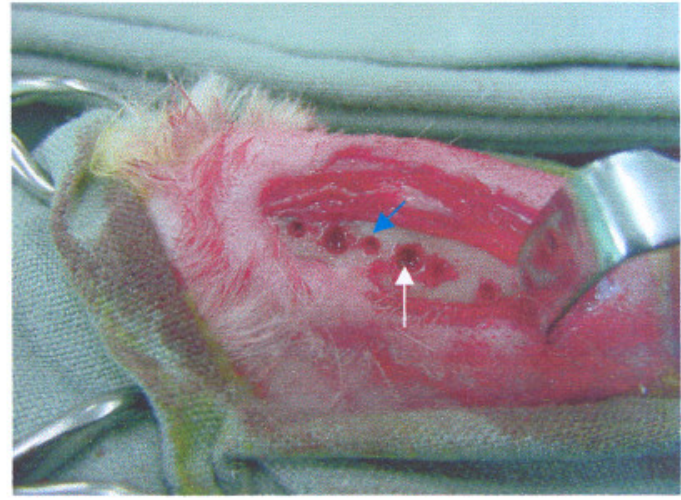

b)

Figura 4.10 - Descrição da técnica cirúrgica: a) realização dos furos maiores (broca de $2,5 \mathrm{~mm}$ de diâmetro), utilizando o guia, que servirão de locais de análise de crescimento ósseo; b) demonstração dos furos para os parafusos da placa (seta azul) e os furos, para análise de crescimento ósseo (seta branca).

A placa de osteossíntese foi então fixada ao osso por quatro parafusos inseridos nas respectivas perfurações já mencionadas, com uma chave própria às fendas da cabeça do parafuso. O filme de PVDF foi colocado entre o plano inferior da placa e plano do osso, ficando uma superfície integra do polímero (visto que o polímero também é perfurado para a passagem dos parafusos) sobre a lesão (Figura 4.11);

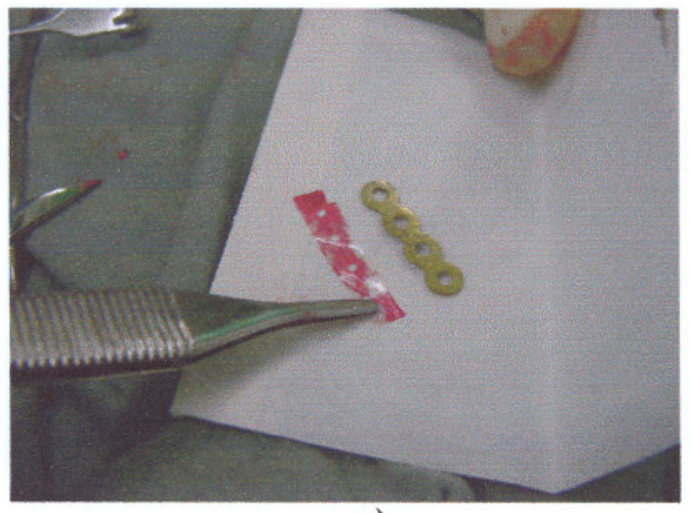

a)

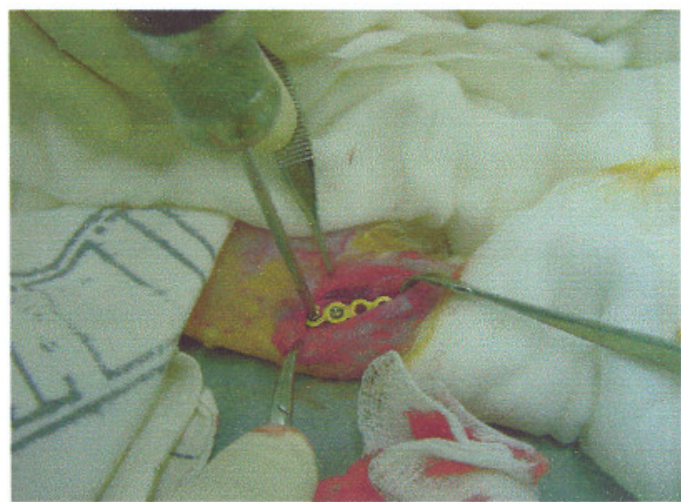

b)

Figura 4.11 - Descrição da técnica cirúrgica: a) detalhe do polímero implantado com os furos para passagem dos parafusos; b) fixação do polímero (entre a tíbia e a placa) utilizando chave especial;

Realizada a revisão da hemostasia e a lavagem com soro fisiológico estéril deu-se início ao fechamento do plano muscular (sutura) com pontos simples separados, utilizando fio mononylon 4-0 e em seguida, fechamento da pele (sutura) com pontos simples separados, utilizando fio mononylon 4-0 (Figura 4.12b). 


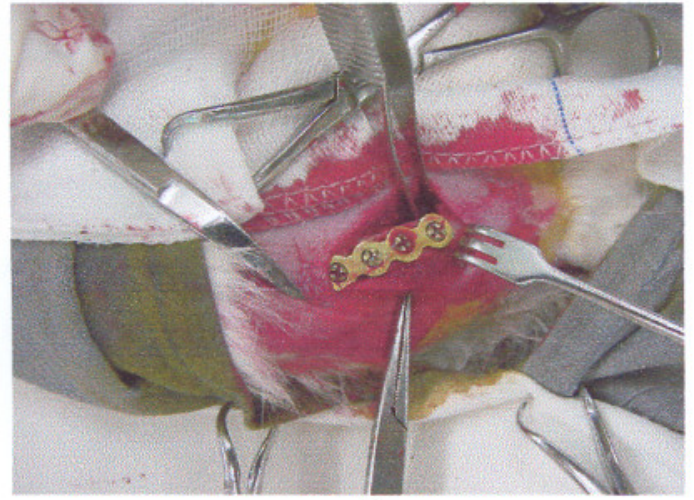

a)

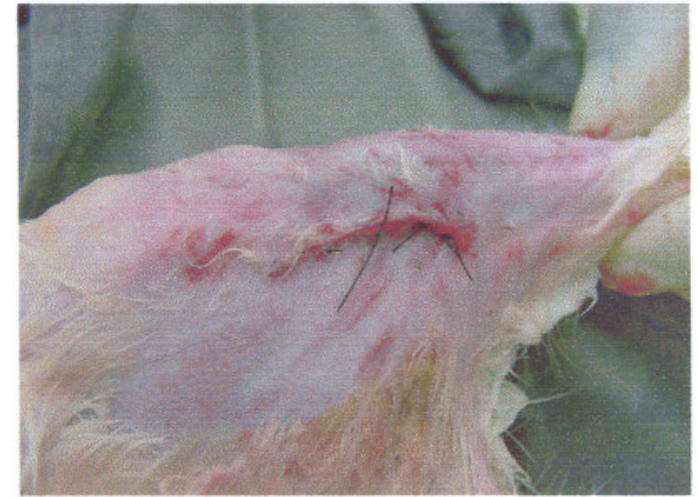

b)

Figura 4.12 - Descrição da técnica cirúrgica: a) placa e polímero fixado; b) sutura finalizada.

Os mesmos procedimentos foram repetidos no lado contra-lateral, exceto quanto à colocação do filme de PVDF (tíbia controle).

Após as cirurgias nas duas patas, foram feitos curativos com gaze, esparadrapo e faixa de crepe e aplicada uma dose de antibiótico (cefazolina sódica).

Para que se pudesse evitar qualquer tendência, optou-se, por colocar o polímero alternando esquerda e direita nas tíbias dos coelhos. Após a cirurgia, os coelhos foram acomodados em caixas de contenção (Figura 4.13), onde receberam analgésico (dipirona sódica) e outra dose de antibiótico (procedimentos pós-operatórios) e permaneceram por 30 dias até a data de sacrificio para retirada das tíbias.

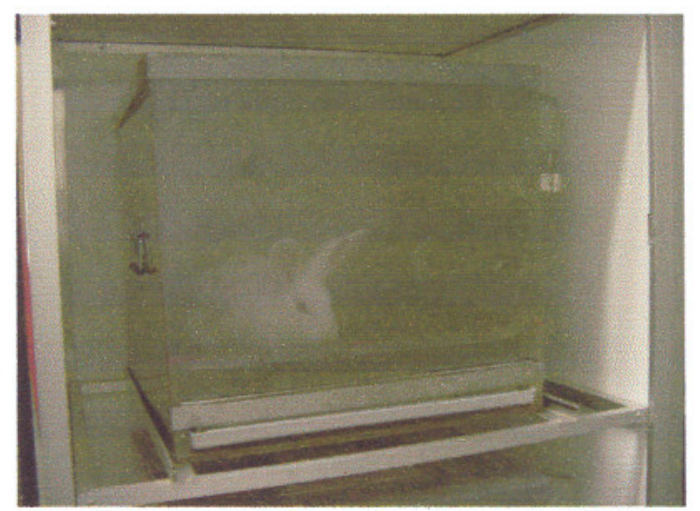

Figura 4.13 - Caixa de contenção (LIM-41 - IOT - HC - FMUSP) 


\subsection{Marcador ósseo - Tetraciclina}

Como citado anteriormente, a tetraciclina é um antibiótico capaz de se ligar a osso em formação, formando duas marcações fluorescentes quando aplicados em um intervalo de tempo determinado.

Contando as quatro semanas, no $14^{\circ}$ e $15^{\circ}$ dias após o implante foram aplicadas, por via subcutânea, as $1^{\mathrm{a}}$ e $2^{\mathrm{a}}$ doses, respectivamente, de tetraciclina na dose $20 \mathrm{mg} / \mathrm{kg}$ de peso corpóreo; No $27^{\circ}$ e $28^{\circ}$ dias, foram injetadas as $3^{\mathrm{a}}$ e $4^{\mathrm{a}}$ doses do antibiótico, na mesma quantidade.

Abaixo, são citados os passos mais importantes durante os trinta dias entre o implante e a eutanásia. A Tabela 12.1 do Anexo E mostra o exemplo de tabela diária utilizada para controle de cada coelho ensaiado.

$1^{\circ}$ dia - Implante do polímero.

$2^{\circ}$ dia - Retirada dos curativos e aplicação de mais uma dose de antibiótico.

$12^{\circ}$ dia - Início dos exercícios físicos em esteira. (para os grupos selecionados).

$14^{\circ}$ dia - Aplicação da $1^{\mathrm{a}}$ dose de tetraciclina $(20 \mathrm{mg} / \mathrm{Kg}$ de peso corpóreo, que se fixa ao osso durante a mineralização).

$15^{\circ}$ dia - Aplicação da $2^{a}$ dose de tetraciclina.

$27^{\circ}$ dia - Aplicação da $3^{\mathbf{a}}$ dose de tetraciclina.

$28^{\circ}$ dia - Aplicação da $4^{a}$ dose de tetraciclina.

$30^{\circ}$ dia - Eutanásia, dissecação e encaminhamento ao laboratório para inicio do processo de emblocamento das peças anatômicas.

O período de 30 dias entre implante e eutanásia foi determinado em função de observações anteriores, que demonstraram que 8 semanas (determinado por alguns autores como um tempo ideal para observações de crescimento ósseo em coelhos) era tempo demais para a observação com a tetraciclina, pois as marcações eram dificeis de serem encontradas e o furo se achava completamente calcificado (fechado). 


\subsection{Protocolo de exercício físico e esteira}

Para se observar se o efeito piezelétrico do polímero surtiria algum efeito sobre o a lesão óssea quando mecanicamente estimulado, um protocolo onde alguns coelhos seriam submetidos a exercícios físicos foi esquematizado.

Um grupo de coelhos foi escolhido para a realização de exercício físico em esteira rolante adaptada. Buscou-se com isso, conseguir um parâmetro de comparação adicional, ou seja, entre patas com e sem polímero, e patas com e sem exercício, verificando se a propriedade piezelétrica poderia se manifestar no polímero a partir da energia mecânica oferecida pelo exercício físico dos animais e, com isso, transmitir uma indução de polarização elétrica ao osso.

Seguindo algumas etapas do protocolo ditado por Rosa-Matielo ${ }^{[82]}$, foi montado o protocolo para os exercícios em esteira para os coelhos operados. Dessa maneira ficou determinado que os exercícios deveriam ser realizados diariamente, a partir do $12^{\circ}$ dia póscirúrgico, obedecendo a uma velocidade aproximada de $14 \mathrm{~m} / \mathrm{min}$. Os animais são submetidos a 10 minutos no aparelho desligado para ambientação e depois é iniciada a sessão de exercícios. Cada animal é exercitado por 5 minutos, repousa 5 minutos e retoma a atividade por mais 5 minutos. Este protocolo é realizado por 14 dias, até a eutanásia, seguindo:

5 dias de exercicio $\left(12^{\circ}\right.$ ao $16^{\circ}$ dia) e 2 dias de intervalo

5 dias de exercício $\left(19^{\circ}\right.$ ao $23^{\circ}$ dia) e 2 dias de intervalo

4 dias de exercício $\left(26^{\circ}\right.$ ao $29^{\circ}$ dia) e eutanásia ( $30^{\circ}$ dia)

Para os exercícios fisicos, uma esteira ergométrica humana convencional foi adaptada para se adequar aos exercícios dos coelhos (Anexo F). A adaptação foi necessária para se poder chegar a uma rotação da esteira em aproximadamente $14 \mathrm{~m} / \mathrm{min}$ (coelho em caminhada normal) e para sua contenção durante os exercícios físicos. 


\subsection{Eutanásia}

Trinta dias após a data do implante, a eutanásia foi realizada. Os animais foram anestesiados e, após o efeito do fármaco estabelecido, receberam uma injeção de cloreto de potássio, por punção cardíaca, ocasionando o sacrifício quase que instantâneo. Está é uma prática bastante utilizada, pois visa um sacrificio mais humanitário tentando minimizar, tanto o quanto o possivel, o sofrimento do animal.

Em todas as etapas do trabalho, onde animais estiveram envolvidos, foram seguidas as recomendações de um protocolo ético ${ }^{[76,77,80]}$. O Anexo $\mathrm{G}$ mostra um protocolo sugerido pelo COBEA.

\subsection{Preparação das amostras para contagem histomorfométrica}

\subsubsection{Dissecação}

As tíbias dos coelhos foram dissecadas, cortadas com o auxilio do mesmo equipamento usado para se fazer os furos na tíbia na cirurgia, porém, deste caso, com um disco de corte em aço. A seguir, todo o procedimento convencional para o embutimento em resina acrílica foi efetuado. Este procedimentơ é usualmente adotado para confecção de lâminas de material ósseo não descalcificado, utilizado nas medidas histomorfométricas. Todo o procedimento está detalhado no Anexo $\mathrm{H}$. 


\subsection{Parâmetros para medição - Histomorfometria}

Foram feitas laminas histológicas com as amostras teciduais lesadas com cortes de $5 \mu \mathrm{m}$ (coradas em azul de toluidina) e $10 \mu \mathrm{m}$ (sem coloração) para observação em microscópios ópticos comum e de ultravioleta respectivamente. Cabe ressaltar que apenas 15 pares de tíbias foram comparadas nestas análises (8 coelhos sedentários e 7 coelhos submetidos a exercícios) devido a perda de amostras no ato da confecção de algumas das lâminas ou problemas ocorridos no momento da leitura.

A seguir, foram iniciadas as contagens dos componentes ósseos:

1 - Dados estáticos:

- Área óssea (B. Ar $\mathrm{mm}^{2}$ ) - área óssea total mensurada expressa em milímetros quadrados; - Área trabecular (Tb.Pf.Ar $\mathrm{mm}^{2}$ ) - Árẹa trabecular óssea expressa em milímetros quadrados; - Área osteóide (O. Ar $\mathrm{mm}^{2}$ ) - Árẹa referente a osso não mineralizado expressa em milímetros quadrados;

- Área medular (Ma.Ar mm²) - Área referente a medula expressa em milímetros quadrados;

- Área Mineralizada (Md.Ar $\mathrm{mm}^{2}$ ) - Área referente a osso mineralizado expressa em milimetros quadrados;

- Área Fibrose (Fb.Ar mm²) - Área referente a fibrose expressa em milímetros quadrados;

- Perímetro de Remodelamento (Pm.Rm mm) - região referente a ocorrência de remodelamento ósseo expresso em milímetros;

- Volume ósseo (BV/TV \%) - Percentual do volume ósseo total (medula e trabécula), constituído por osso mineralizado ou não;

- Volume osteóide (OV/BV \%) - Percentual do volume ósseo trabecular constituído por osso não mineralizado (osteóide);

- Superficie osteóide (OS/BS \%) - Percentual da superficie trabecular recoberta por matriz osteóide;

- Fibrose (Fb.I/BS \%) - Percentual de fibrose;

- Superficie osteoblática (Ob.S/BS \%) - percentual da superficie trabecular que apresenta osteoblastos;

- Superfície de Reabsorção (ES/BS \%) - Percentual da superficie trabecular que apresenta lacunas de reabsorção, com ou sem osteoclastos;

- Superficie osteoclástica (Oc.S/BS \%) - Percentual da superficie trabecular que apresenta osteoclastos;

- Espessura Trabecular (Tb.Th $\mu \mathrm{m})$ - Espessura das trabéculas ósseas expressa em 
micrômetros;

- Espessura Osteóide (O.Th $\mu \mathrm{m})$ - Espessura do rebordo da matriz osteóide expressa em micrômetros;

- Separação Trabecular (Tb.Sp $\mu \mathrm{m})$ - Distância entre as trabéculas ósseas expressa em micrômetros;

- Número Trabecular (Tb.N/mm) - Número de trabéculas ósseas por milímetro de tecido, sendo também o índice que expressa a densidade trabecular.

\section{2- Dados Dinâmicos}

- Taxa de Aposição Mineral (MAR mm/dia) - Distância entre as duas marcações feitas pela tetraciclina fixada dividida pelo intervalo de tempo entre uma e outra aplicação da mesma (expressa em micrômetros por dia).

O procedimento utilizado para a obtenção dos dados acima mencionados é o método semi-automático, onde computadores e câmeras de vídeo (ou câmeras claras) são empregados. Esse método se baseia na construção das imagens histológicas na tela do computador através do manuseio de um mouse (cursor) específico, contendo um ponto de luz, sobre uma placa digitalizadora que é calibrada para fornecer á área de contagem. Essa área é observada simultaneamente com a lâmina histológica e o ponto de luz é usado para marcar o que se desejar mensurar. Como previamente a escolha do item a ser medido já está determinado pelo usuário no computador, todo local escolhido, através do ponto de luz e selecionado com a tecla do mouse, é captado pelo software, que armazena e calcula esses parâmetros. Essa é uma técnica de uma ótima precisão, reprodutível e que reduz o tempo de leitura histológica quando comparado a técnica manual, além de possibilitar ao operador a eliminação de artefatos histológicos. Nas Figuras 4.14, 4.15 e 4.16 é possível ver o equipamento todo e alguns detalhes do conjunto computador/microscópio/câmera/placa digitalizadora de campo/cursor. Neste estudo, portanto, utilizou-se para as leituras histomorfométricas o equipamento composto por microcomputador contendo software Osteomensure (OsteoMetrics, Inc.Atlanta - EUA.) microscópio provido de luz ultravioleta (Labophot $2^{A}$ Nikon), cursor e placa digitalizadora. 


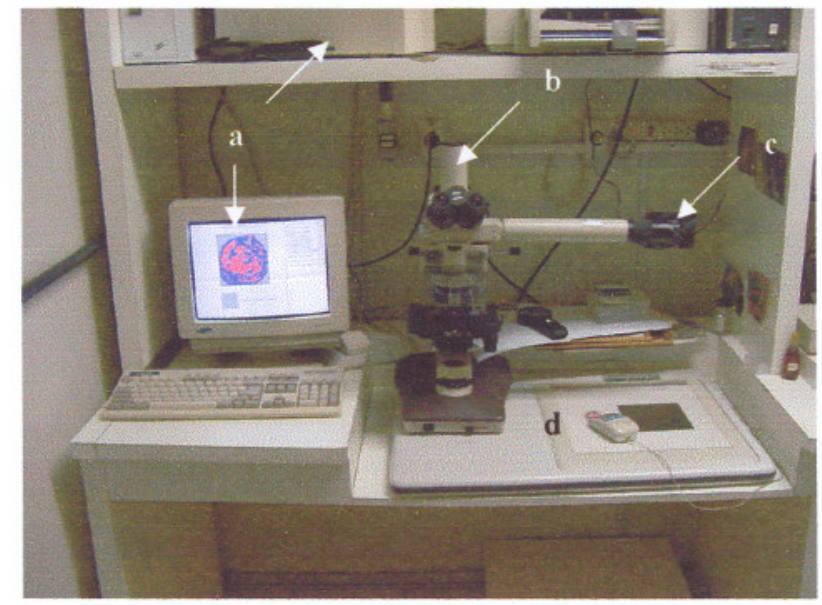

Figura 4.14 - Equipamento para medidas histomorfométricas: a) microcomputador/monitor; b) microscópio; c) câmera; d) mouse (cursor) e placa digitalizadora com campo de mensuração (integrado ao software).

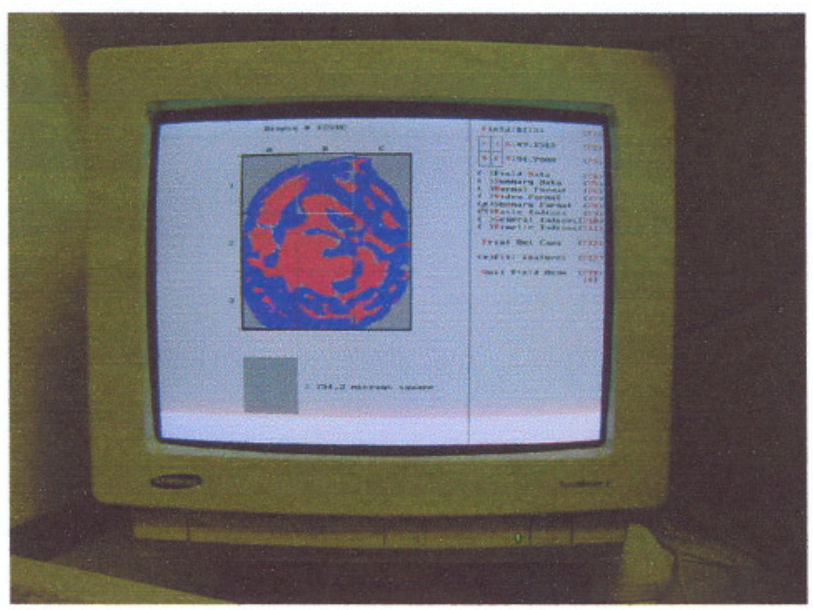

Figura 4.15 - Detalhe da imagem digitalizada da lesão óssea provocada nas tíbias. Note que foram necessários nove campos para formar a imagem (cada campo corresponde a um dos quadrados da figura).

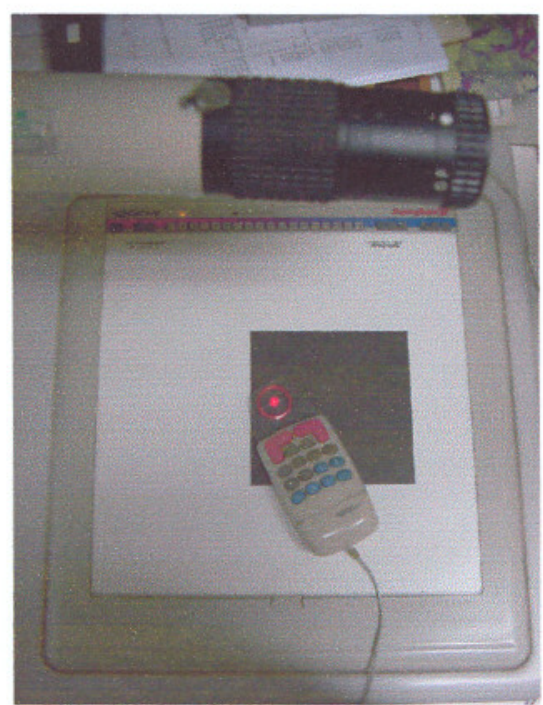

Figura 4.16 - Placa digitalizadora com a área de medição (quadrado negro ao centro), do mouse/cursor (sobre o quadrado) e da câmera (seta) que sobrepõe as imagens da lâmina e do campo. 


\subsubsection{Coleta de dados histomorfométricos}

As medidas foram realizadas em campos de aproximadamente $753 \mu^{2}$, sendo necessários de 9 a 12 campos (detalhe do campo na Figura 4.17a) para a formação da imagem da lesão provocada na tíbia dos coelhos (Figura 4.17b). Cada campo é individualmente montado e mensurado. Após a imagem montada, um relatório geral é emitido fornecendo as porcentagens e medidas realizadas.

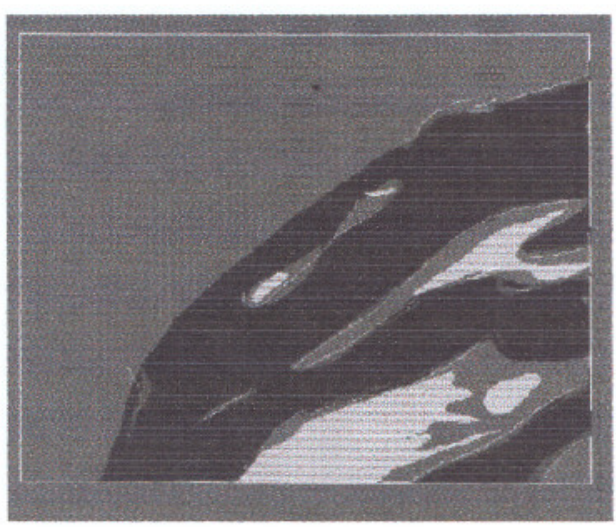

a)

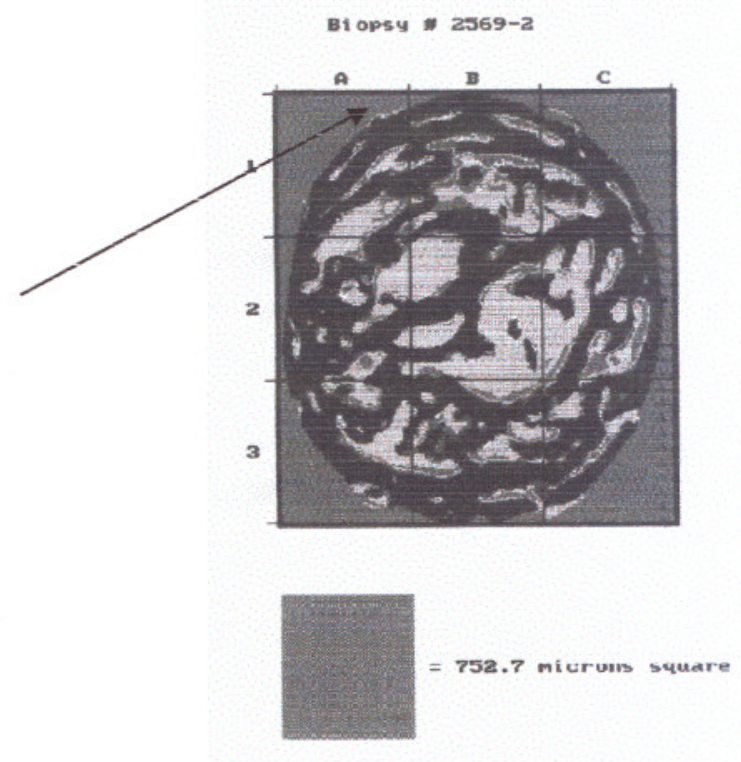

b)

Figura 4.17 - Imagens demonstrando a montagem digitalizada da lesão da tíbia: a) detalhe do campo com imagem digitalizada; b) Imagens da lesão na tíbia digitalizada, montada com nove campos. Abaixo, detalhe da área de medição (quadrado cinza), com a calibração correspondente.

\subsubsection{Analise Estatística}

Os dados foram submetidos à análise estatística descritiva, determinando-se os valores referidos como média, desvio padrão, erro padrão da média, valor máximo, valor mínimo e número de amostras.

Para verificar a diferença entre o grupo controle (sem polímero) e grupo implantado (com polímero), (teste pareado) foi utilizado o teste de Wilcoxon para amostras nãoparamétricas. Para verificar a diferença entre o grupo com e sem exercício (teste nãopareado) com polímero e sem polímero, foi utilizado o teste de Mann-Whitney para amostras não-paramétricas. Estes tipos de tratamentos estatísticos são muitas vezes aplicados devido a ocorrência da variabilidade entre indivíduos de uma mesma espécie. 


\subsection{Análise morfológica - Histologia}

Das mesmas lâminas histológicas com cortes de $5 \mu \mathrm{m}$ e coradas em azul de toluidina utilizadas para as contagens histomorfométricas, foram separadas 66 exemplares e numeradas de 1 a 34 (a maioria delas em duplicatas), de forma que não se soubesse a que tíbia elas estariam referenciando, portanto, o examinador não tinha conhecimento do tratamento recebido pelos animais. Essas lâminas foram analisadas "às cegas" por um médico especialista em anatomia e patologia tecidual óssea ${ }^{8}$.

Cada lâmina recebeu uma graduação de $(+)$ a $(++++)$ para dimensionar a formação de trabéculas ósseas. Após essa análise, os grupos com e sem polímero, com e sem exercício foram comparados.

Para a realização deste laudo foram comparadas as tíbias de 17 coelhos. A perda de amostras dos outros três implantados deu-se pelos mesmos motivos já mencionados anteriormente.

8 Análises realizadas pela Dr*. Elizete Lopes Guilherme, do Instituto de Anatomia Patológica de São Carlos. 


\section{Resultados e Discussões}

\subsection{Teste de Esterilização}

Os valores das medidas dos coeficientes piroelétricos do PVDF são apresentados na Tabela 5.1. Pode-se observar que os processos de esterilização por óxido de etileno e por radiação (por fonte de $\mathrm{Co}^{60}$ ) não alteraram significativamente o valor da polarização ferroelétrica original, com destaque para o óxido de etileno, cujo valor não se alterou (o erro nas medidas é de aproximadamente 5\%). A Figura 5.1 traz dois gráficos que mostram a perda da polarização pelo método de radiação e a permanência da polarização inicial pelo método de óxido de etileno após o PVDF esterilizado.

Tabela 5.1 - Comparação do coeficiente piroelétrico $\left(e m \mu \mathrm{Cm}^{-2} \mathrm{~K}^{-1}\right)$ medido antes $\left(\mathrm{p}_{1}\right)$ e depois $\left(\mathrm{p}_{2}\right)$ do processo de esterilização. As amostras foram polarizadas sob as mesmas condições.

\begin{tabular}{c|ccccc}
\hline $\begin{array}{c}\text { Processo de } \\
\text { Esterilização }\end{array}$ & $\begin{array}{c}\text { Amostras } \\
\mathbf{n}^{\mathbf{0}}\end{array}$ & $\mathbf{p}_{\mathbf{1}}$ & $\mathbf{p}_{\mathbf{2}}$ & $\begin{array}{c}\Delta \mathbf{p} \\
\text { (unid.) }\end{array}$ & $\begin{array}{c}\Delta \mathbf{p} \\
(\%)\end{array}$ \\
\hline $\begin{array}{c}\text { Óxido de } \\
\text { Etileno (EtO) }\end{array}$ & 1 & 33 & 33 & 0 & 0 \\
& 2 & 33 & 33 & 0 & 0 \\
\hline Média & 3 & 37 & 37 & 0 & 0 \\
\hline Desvio Padrão & & 34,33 & 34,33 & 0 & 0 \\
\hline Radiação & 4 & 2,31 & 2,31 & 0 & 0 \\
(Fonte Co $^{60}$ ) & 5 & 30 & 38 & 2 & 5,0 \\
\hline Média & 6 & 39 & 36 & 3 & 7,7 \\
\hline Desvio Padrão & & 39,33 & 37,33 & 2 & 5,1 \\
\hline \multicolumn{1}{|c}{} & & 0,58 & 1,15 & 1 & 2,55 \\
\hline
\end{tabular}

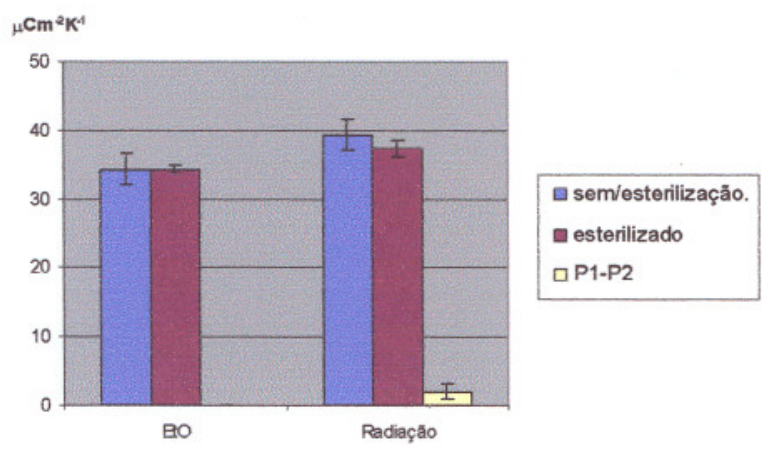

a)

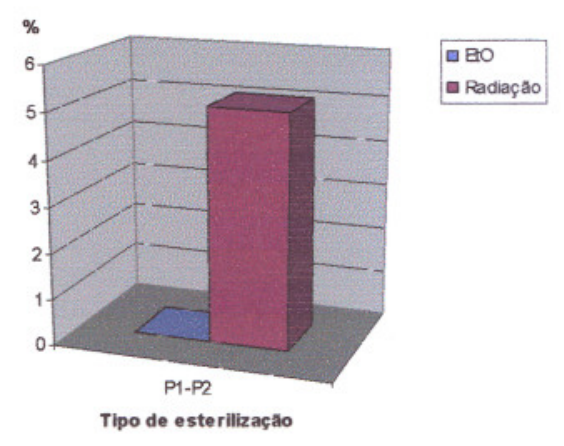

b)

Figura 5.1 - Gráficos demonstrando a perda da polarização do PVDF devido aos processos de esterilização por óxido de etileno (EtO) e Radiação por fonte de cobalto 60 . a) em coeficiente piroelétrico $\left(\mu \mathrm{Cm}^{-2} \mathrm{~K}^{-1}\right)$; b) em porcentagem. 


\subsection{Teste de Citotoxicidade}

O teste de citotoxicidade forneceu um valor importante, como passo para garantir a biocompatibilidade do PVDF, pois a linhagem celular NCTC clone 929.(CCL1-ATTC-USA) não apresentou qualquer resposta que indicasse toxicidade para este material, sob as condições de exposição do teste de difusão em ágar. A Tabela 5.2 apresenta os resultados do teste de citoxicidade constante na avaliação do Instituto Adolfo Lutz (Anexo B)

Tabela 5.2 - Resultados de citotoxidade na leitura das placas de culturas celulares.

\begin{tabular}{lcccc}
\hline Amostras & $\begin{array}{c}\text { Índice de } \\
\text { zona (IZ) }\end{array}$ & $\begin{array}{c}\text { Indice de } \\
\text { lise (L) }\end{array}$ & $\begin{array}{c}\text { Indice de } \\
\text { resposta } \\
\text { (IZ/L) }\end{array}$ \\
\hline \multirow{3}{*}{ PVDF } & $\mathrm{n}^{\circ} 1$ & 0 & 0 & $0 / 0$ \\
& $\mathrm{n}^{\circ} 2$ & 0 & 0 & $0 / 0$ \\
& $\mathrm{n}^{\circ} 3$ & 0 & 0 & $0 / 0$ \\
& $\mathrm{n}^{\circ} 4$ & 0 & 0 & $0 / 0$ \\
\hline \multirow{2}{*}{ Controle } & $\mathrm{n}^{\circ} 1$ & 0 & 0 & $0 / 0$ \\
negativo & $\mathrm{n}^{\circ} 2$ & 0 & 0 & $0 / 0$ \\
& $\mathrm{n}^{\circ} 3$ & 0 & 0 & $0 / 0$ \\
& $\mathrm{n}^{\circ} 4$ & 0 & 0 & $0 / 0$ \\
\hline \multirow{3}{*}{ Controle } & $\mathrm{n}^{\circ} 1$ & 5 & 3 & $5 / 3$ \\
positivo & $\mathrm{n}^{\circ} 2$ & 5 & 3 & $5 / 3$ \\
& $\mathrm{n}^{\circ} 3$ & 5 & 3 & $5 / 3$ \\
& $\mathrm{n}^{\circ} 4$ & 5 & 3 & $5 / 3$ \\
\hline
\end{tabular}

O resultado nulo (zero), obtido pelas amostras, indica que o PVDF não apresenta elementos adversos extraíveis, existentes em sua formulação ou adquiridos durante o processamento em quantidades suficientes para causar efeitos agudos sob as condições concentradas a que foram expostas as células em cultura. 


\subsection{Teste de Sensibilidade Intracutânea}

As Tabelas do Apêndice I trazem os dados das observações realizadas nos testes de sensibilidade intracutânea realizados nos cinco coelhos marcados como A1, A2, A3, A4 e A5 que receberam inoculações com Extratos e Controles. Na Tabela 5.3 estão os resultados que representa a Contágem de Irritação Primária (CIP) ocorrida em cada animal.

Tabela 5.3 - Resultado das Contagens de Irritação Primária para os animais ensaiados.

\begin{tabular}{c|c} 
Animais & CIP \\
\hline A1 & $-0,07$ \\
A2 & 0,14 \\
A3 & 0,07 \\
A4 & 0,00 \\
A5 & 0,14
\end{tabular}

Para a obtenção do Índice de Irritação Primária, somaram-se as Contagens de Irritação Primária dos animais e dividiu-se pelo número de animas ensaiados. Dessa forma:

$$
\begin{aligned}
& \mathbf{I I P}=(\mathrm{A} 1+\mathrm{A} 2+\mathrm{A} 3+\mathrm{A} 4+\mathrm{A} 5): 5 \\
& \mathbf{I I P}=[(-0,07)+0,14+0,07+0,00+0,14]: 5 \\
& \mathbf{I I P}=0,28: 5 \\
& \mathbf{I I P} \cong \mathbf{0 , 0 6}
\end{aligned}
$$

Seguindo a Tabela 4.4, este valor acima, ou seja, o Índice de Irritação Primária, revelou uma situação NEGLIGENCIÁVEL de sensibilidade intracutânea ao PVDF (IIP entre 0 e 0,4). 


\subsection{Teste de Toxicidade Sistêmica}

A Tabela 5.4 mostrada o resultado obtido das pesagens e das reações apresentadas pelos camundongos após a aplicação dos Extratos/Veículos de extração.

A comparação foi realizada através da observação dos efeitos provocados pelo extrato com seu veículo de extração. Portanto observou-se que, para os grupos inoculados com Extrato Polar/Veículo de Extração Polar, houve apenas uma redução de peso nas primeiras 24 horas, (observando que existe uma elevação do peso dos animais no tempo 0 (zero) devido a inoculação dos extratos/controles) voltando a aumentar nas observações subseqüentes de 48 e 72 horas, sem nenhuma reação adversa notada em nenhuma das observações, sendo considerada, portanto, como NORMAL, segundo a Tabela 4.6. O mesmo ocorreu para os grupos inoculados com Extrato Não-Polar/Veículo de Extração Não-Polar e para o Extrato Intermediário/Veículo de Extração Intermediário, apresentando somente uma reação LEVE nas primeiras 24 horas e NORMAL, com aumento gradativo de peso, para as outras observações.

Através da Tabela 5.5, pôde-se observar que os pesos corpóreos dos 30 camundongos, entre as tomadas de dados iniciais (antes da inoculação) e finais (72 horas após a inoculação), que 57\% deles apresentaram aumento acima do inicial (em cinza), 10\% chegaram ao peso inicial (em azul) e $33 \%$ se mantiveram abaixo do peso inicial, porém, com variação mínima (em amarelo). As Figuras 5.2, 5.3 e·5.4 mostram gráficos com a média dos pesos perdidos e recuperados pelos animais para os grupos de extratos/controles dos teste de toxicidade sistêmica em todos os tempos. Os gráficos das Figuras 5.5, 5.6 e 5.7, demonstram o quadro evolutivo do comportamento de LEVE para NORMAL apresentado pelos camundongos inoculados com os mesmos extratos e controles.

A Tabela 5.6 mostra os valores médios de peso corpóreo dos animais em gramas e os indices apresentados. Numa média geral, as reações se estabeleceram entre NORMAL (60\%) e LEVE (40\%) para a leitura no ato da inoculação, NORMAL (87\%) e LEVE (13\%) para as primeiras 24 horas e NORMAL (100\%) para as leituras de 48 e 72 horas e a Figura 5.8 apresenta um gráfico com todos os animais ensaiados neste teste, mostrando a recuperação ao estado comportamental NORMAL dos camundongos ensaiados ao final das $\mathbf{7 2}$ horas. Isso vem demonstrar que o PVDF, submetido ao teste de Toxicidade Sistêmica, foi aprovado, já que ele se apresentou como um material que não libera componentes tóxicos ou causadores de reações adversas de sua composição nos meios ensaiados. 
Tabela 5.4 - Tabela de pesos e índices de toxicidade sistêmica para os grupos das soluções ensaiadas.

\begin{tabular}{|c|c|c|c|c|c|c|}
\hline & $\begin{array}{l}\text { Extrato } \\
\text { Polar }\end{array}$ & $\begin{array}{c}\text { Controle } \\
\text { Polar } \\
\end{array}$ & $\begin{array}{c}\text { Extrato } \\
\text { Intermediário } \\
\end{array}$ & $\begin{array}{c}\text { Controle } \\
\text { intermediário }\end{array}$ & $\begin{array}{c}\text { Extrato } \\
\text { Não Polar }\end{array}$ & $\begin{array}{c}\text { Controle } \\
\text { Não Polar }\end{array}$ \\
\hline & Grupo 1 & Grupo 2 & Grupo 3 & Grupo 4 & Grupo 5 & Grupo 6 \\
\hline \multirow{5}{*}{$\begin{array}{l}0 \text { horas } \\
\text { (Injeção) }\end{array}$} & $\begin{array}{l}\text { Peso: } 47,0 \\
\text { indice: } 0\end{array}$ & $\begin{array}{l}\text { Peso: } 40,9 \\
\text { indice: } 0\end{array}$ & $\begin{array}{l}\text { Peso: } 42,5 \\
\text { indice: } 0\end{array}$ & $\begin{array}{l}\text { Peso: } 41,0 \\
\text { indice: } 0\end{array}$ & $\begin{array}{l}\text { Peso: } 48,4 \\
\text { indice: } 1\end{array}$ & $\begin{array}{l}\text { Peso: } 43,7 \\
\text { indice: } 1\end{array}$ \\
\hline & $\begin{array}{l}{ }^{2} \text { Peso: } 54,2 \\
\text { indice: } 0\end{array}$ & $\begin{array}{l}{ }^{2} \text { Peso: } 50,0 \\
\text { indice: } 0\end{array}$ & $\begin{array}{l}{ }^{2} \text { Peso: } 49,3 \\
\text { indice: } 0\end{array}$ & $\begin{array}{l}{ }^{2} \text { Peso: } 44,1 \\
\text { indice: } 0\end{array}$ & $\begin{array}{l}{ }^{2} \text { Peso: } 41,8 \\
\text { indice: } 1\end{array}$ & $\begin{array}{l}{ }^{2} \text { Peso: } 40,5 \\
\text { indice: } 1\end{array}$ \\
\hline & $\begin{array}{l}{ }^{3} \text { Peso: } 53,0 \\
\text { indice: } 0\end{array}$ & $\begin{array}{l}{ }^{3} \text { Peso: } 44,2 \\
\text { indice: } 0\end{array}$ & $\begin{array}{l}{ }^{3} \text { Peso: } 45,9 \\
\text { índice: } 0\end{array}$ & $\begin{array}{l}{ }^{3} \text { Peso: } 41,9 \\
\text { indice: } 0\end{array}$ & $\begin{array}{l}{ }^{3} \text { Peso: } 45,0 \\
\text { indice: } 1\end{array}$ & $\begin{array}{l}{ }^{3} \text { Peso: } 50,2 \\
\text { indice: } 1\end{array}$ \\
\hline & $\begin{array}{l}{ }^{4} \text { Peso: } 41,6 \\
\text { indice: } 0\end{array}$ & $\begin{array}{l}{ }^{4} \text { Peso: } 44,8 \\
\text { indice: } 0\end{array}$ & $\begin{array}{l}{ }^{4} \text { Peso: } 34,1 \\
\text { indice: } 1\end{array}$ & $\begin{array}{l}{ }^{4} \text { Peso: } 41,3 \\
\text { indice: } 1\end{array}$ & $\begin{array}{l}\text { Peso: } 43,2 \\
\text { indice: } 1\end{array}$ & $\begin{array}{l}\text { Peso: } 46,3 \\
\text { indice: } 1\end{array}$ \\
\hline & $\begin{array}{l}{ }^{5} \text { Peso: } 41,7 \\
\text { indice: } 0\end{array}$ & $\begin{array}{l}{ }^{5} \text { Peso:41,2 } \\
\text { indice: } 0\end{array}$ & $\begin{array}{l}{ }^{5} \text { Peso: } 41,0 \\
\text { indice: } 0\end{array}$ & $\begin{array}{l}{ }^{5} \text { Peso: } 44,1 \\
\text { indice: } 1\end{array}$ & $\begin{array}{l}{ }^{5} \text { Peso:47,6 } \\
\text { indice: } 1\end{array}$ & $\begin{array}{l}{ }^{5} \text { Peso: } 42,6 \\
\text { indice: } 1\end{array}$ \\
\hline \multirow{5}{*}{24 horas } & $\begin{array}{l}\text { Peso: } 45,6 \\
\text { indice: } 0\end{array}$ & $\begin{array}{l}\text { Peso: } 42,3 \\
\text { indice: } 0\end{array}$ & $\begin{array}{l}\text { Peso: } 36,6 \\
\text { indice: } 0\end{array}$ & $\begin{array}{l}\text { Peso: } 38,6 \\
\text { indice: } 0\end{array}$ & $\begin{array}{l}\text { Peso: } 46,2 \\
\text { indice: } 0\end{array}$ & $\begin{array}{l}\text { Peso: } 45,2 \\
\text { indice: } 1\end{array}$ \\
\hline & $\begin{array}{l}{ }^{2} \text { Peso: } 53,7 \\
\text { indice: } 0\end{array}$ & $\begin{array}{l}{ }^{2} \text { Peso: } 48,3 \\
\text { indice: } 0\end{array}$ & $\begin{array}{l}{ }^{2} \text { Peso: } 47,9 \\
\text { indice: } 0\end{array}$ & $\begin{array}{l}{ }^{2} \text { Peso: } 41,8 \\
\text { indice: } 0\end{array}$ & $\begin{array}{l}{ }^{2} \text { Peso: } 40,6 \\
\text { indice: } 0\end{array}$ & $\begin{array}{l}{ }^{2} \text { Peso: } 39,2 \\
\text { indice: } 1\end{array}$ \\
\hline & $\begin{array}{l}{ }^{3} \text { Peso: } 51,0 \\
\text { indice: } 0\end{array}$ & $\begin{array}{l}{ }^{3} \text { Peso: } 43,8 \\
\text { indice: } 0\end{array}$ & $\begin{array}{l}{ }^{3} \text { Peso: } 45,7 \\
\text { indice: } 0\end{array}$ & $\begin{array}{l}{ }^{3} \text { Peso: } 39,8 \\
\text { indice: } 0\end{array}$ & $\begin{array}{l}{ }^{3} \text { Peso: } 44,2 \\
\text { indice: } 1\end{array}$ & $\begin{array}{l}{ }^{3} \text { Peso: } 47,2 \\
\text { indice: } 0\end{array}$ \\
\hline & $\begin{array}{l}{ }^{4} \text { Peso: } 41,6 \\
\text { indice: } 0\end{array}$ & $\begin{array}{l}{ }^{4} \text { Peso: } 44,0 \\
\text { indice: } 0\end{array}$ & $\begin{array}{l}{ }^{4} \text { Peso: } 32,4 \\
\text { indice: } 0\end{array}$ & $\begin{array}{l}{ }^{4} \text { Peso: } 39,0 \\
\text { indice: } 0\end{array}$ & $\begin{array}{l}{ }^{4} \text { Peso: } 41,1 \\
\text { indice: } 1\end{array}$ & $\begin{array}{l}{ }^{4} \text { Peso: } 44,2 \\
\text { indice: } 0\end{array}$ \\
\hline & $\begin{array}{l}\text { Peso:40,6 } \\
\text { indice: } 0\end{array}$ & $\begin{array}{l}\text { Peso: } 38,6 \\
\text { indice: } 0\end{array}$ & $\begin{array}{l}\text { Peso:40,1 } \\
\text { indice: } 0\end{array}$ & $\begin{array}{l}\text { Peso: } 39,3 \\
\text { indice: } 0\end{array}$ & $\begin{array}{l}{ }^{5} \text { Peso: } 45,5 \\
\text { indice: } 0\end{array}$ & $\begin{array}{l}{ }^{5} \text { Peso: } 39,0 \\
\text { indice: } 0\end{array}$ \\
\hline \multirow{5}{*}{48 horas } & $\begin{array}{l}\text { Peso: } 46,5 \\
\text { indice: } 0\end{array}$ & $\begin{array}{l}\text { Peso: } 43,2 \\
\text { indice: } 0\end{array}$ & $\begin{array}{l}\text { Peso: } 40,7 \\
\text { indice: } 0\end{array}$ & $\begin{array}{l}\text { Peso: } 38,7 \\
\text { indice: } 0\end{array}$ & $\begin{array}{l}\text { Peso: } 45,9 \\
\text { indice: } 0\end{array}$ & $\begin{array}{l}\text { Peso: } 45,3 \\
\text { indice: } 0\end{array}$ \\
\hline & $\begin{array}{l}{ }^{2} \text { Peso: } 52,9 \\
\text { indice: } 0\end{array}$ & $\begin{array}{l}{ }^{2} \text { Peso: } 48,5 \\
\text { indice: } 0\end{array}$ & $\begin{array}{l}{ }^{2} \text { Peso: } 47,0 \\
\text { indice: } 0\end{array}$ & $\begin{array}{l}{ }^{2} \text { Peso: } 42,9 \\
\text { indice: } 0\end{array}$ & $\begin{array}{l}{ }^{2} \text { Peso: } 40,9 \\
\text { indice: } 0\end{array}$ & $\begin{array}{l}{ }^{2} \text { Peso: } 38,5 \\
\text { indice: } 0\end{array}$ \\
\hline & $\begin{array}{l}{ }^{3} \text { Peso: } 51,9 \\
\text { indice: } 0\end{array}$ & $\begin{array}{l}{ }^{3} \text { Peso: } 43,1 \\
\text { indice: } 0\end{array}$ & $\begin{array}{l}{ }^{3} \text { Peso: } 46,0 \\
\text { indice: } 0\end{array}$ & $\begin{array}{l}{ }^{3} \text { Peso: } 41,0 \\
\text { índice: } 0\end{array}$ & $\begin{array}{l}{ }^{3} \text { Peso: } 44,4 \\
\text { indice: } 0\end{array}$ & $\begin{array}{l}{ }^{3} \text { Peso: } 47,7 \\
\text { indice: } 0\end{array}$ \\
\hline & $\begin{array}{l}{ }^{4} \text { Peso: } 41,6 \\
\text { indice: } 0\end{array}$ & $\begin{array}{l}{ }^{4} \text { Peso: } 44,5 \\
\text { indice: } 0\end{array}$ & $\begin{array}{l}{ }^{4} \text { Peso: } 32,4 \\
\text { indice: } 0\end{array}$ & $\begin{array}{l}{ }^{4} \text { Peso: } 39,0 \\
\text { indice: } 0\end{array}$ & $\begin{array}{l}{ }^{4} \text { Peso: } 43,9 \\
\text { indice: } 0\end{array}$ & $\begin{array}{l}{ }^{4} \text { Peso: } 44,2 \\
\text { indice: } 0\end{array}$ \\
\hline & $\begin{array}{l}{ }^{5} \text { Peso: } 39,4 \\
\text { indice: } 0\end{array}$ & $\begin{array}{l}{ }^{5} \text { Peso: } 39,4 \\
\text { indice: } 0\end{array}$ & $\begin{array}{l}{ }^{3} \text { Peso: } 42,2 \\
\text { indice: } 0\end{array}$ & $\begin{array}{l}{ }^{3} \text { Peso: } 39,6 \\
\text { indice: } 0\end{array}$ & $\begin{array}{l}{ }^{5} \text { Peso: } 46,5 \\
\text { indice: } 0\end{array}$ & $\begin{array}{l}{ }^{5} \text { Peso: } 39,6 \\
\text { indice: } 0\end{array}$ \\
\hline \multirow{5}{*}{72 horas } & $\begin{array}{l}\text { Peso: } 46,4 \\
\text { indice: } 0\end{array}$ & $\begin{array}{l}\text { Peso: } 43,2 \\
\text { indice: } 0\end{array}$ & $\begin{array}{l}\text { Peso: } 41,3 \\
\text { indice: } 0\end{array}$ & $\begin{array}{l}\text { Peso: } 39,2 \\
\text { indice: } 0\end{array}$ & $\begin{array}{l}\text { Peso: } 46,4 \\
\text { indice: } 0\end{array}$ & $\begin{array}{l}\text { Peso: } 45,2 \\
\text { indice: } 0\end{array}$ \\
\hline & $\begin{array}{l}{ }^{2} \text { Peso: } 53,7 \\
\text { indice: } 0\end{array}$ & $\begin{array}{l}{ }^{2} \text { Peso: } 48,5 \\
\text { indice: } 0\end{array}$ & $\begin{array}{l}{ }^{2} \text { Peso: } 47,7 \\
\text { indice: } 0\end{array}$ & $\begin{array}{l}{ }^{2} \text { Peso: } 43,0 \\
\text { indice: } 0\end{array}$ & $\begin{array}{l}{ }^{2} \text { Peso: } 41,2 \\
\text { indice: } 0\end{array}$ & $\begin{array}{l}{ }^{2} \text { Peso: } 39,8 \\
\text { indice: } 0\end{array}$ \\
\hline & $\begin{array}{l}{ }^{3} \text { Peso: } 51,7 \\
\text { indice: } 0\end{array}$ & $\begin{array}{l}{ }^{3} \text { Peso: } 43,1 \\
\text { indice: } 0\end{array}$ & $\begin{array}{l}{ }^{3} \text { Peso: } 47,0 \\
\text { indice: } 0\end{array}$ & $\begin{array}{l}{ }^{3} \text { Peso: } 40,9 \\
\text { indice: } 0\end{array}$ & $\begin{array}{l}{ }^{3} \text { Peso: } 44,0 \\
\text { indice: } 0\end{array}$ & $\begin{array}{l}{ }^{3} \text { Peso: } 47,8 \\
\text { indice: } 0\end{array}$ \\
\hline & $\begin{array}{l}{ }^{4} \text { Peso: } 43,1 \\
\text { indice: } 0\end{array}$ & $\begin{array}{l}{ }^{4} \text { Peso: } 43,5 \\
\text { indice: } 0\end{array}$ & $\begin{array}{l}{ }^{4} \text { Peso: } 32,4 \\
\text { indice: } 0\end{array}$ & $\begin{array}{l}{ }^{4} \text { Peso: } 39,8 \\
\text { indice: } 0\end{array}$ & $\begin{array}{l}{ }^{4} \text { Peso: } 42,9 \\
\text { indice: } 0\end{array}$ & $\begin{array}{l}{ }^{4} \text { Peso: } 45,8 \\
\text { indice: } 0\end{array}$ \\
\hline & $\begin{array}{l}{ }^{3} \text { Peso: } 39,3 \\
\text { indice: } 0\end{array}$ & $\begin{array}{l}{ }^{5} \text { Peso: } 39,4 \\
\text { índice: } 0\end{array}$ & $\begin{array}{l}{ }^{5} \text { Peso:41,8 } \\
\text { indice: } 0\end{array}$ & $\begin{array}{l}{ }^{5} \text { Peso: } 39,7 \\
\text { indice: } 0\end{array}$ & $\begin{array}{l}{ }^{5} \text { Peso: } 47,3 \\
\text { indice: } 0\end{array}$ & $\begin{array}{l}{ }^{5} \text { Peso: } 39,7 \\
\text { indice: } 0\end{array}$ \\
\hline
\end{tabular}

Tabela 5.5 - Tabela de pesos iniciais (sem aplicação de extrato/veículo de extração) e finais para os grupos de animais conforme as das soluções ensaiadas.

\begin{tabular}{|c|c|c|c|c|c|c|}
\hline \multirow{2}{*}{$\begin{array}{l}\text { Meios } \\
\text { Animais }\end{array}$} & $\begin{array}{c}\text { GRUPO } 1 \\
\text { EP }\end{array}$ & $\begin{array}{c}\text { GRUPO } 2 \\
\text { CP }\end{array}$ & $\begin{array}{c}\text { GRUPO } 3 \\
\text { EI }\end{array}$ & $\begin{array}{c}\text { GRUPO } 4 \\
\text { CI }\end{array}$ & $\begin{array}{c}\text { GRUPO } 5 \\
\text { EN }\end{array}$ & $\begin{array}{c}\text { GRUPO } 6 \\
\text { CN }\end{array}$ \\
\hline & \multicolumn{6}{|c|}{ Peso em gramas (inicial e final) dos animais de teste } \\
\hline \multirow[t]{2}{*}{1} & Inicial: & Inicial: 40,0 & Inicial: 41,1 & Inicial: 39,1 & Inicial: 47,1 & Inicial: \\
\hline & Final: & Final: & Final: & Final: & Final: & Final: \\
\hline \multirow[t]{2}{*}{2} & Inicial: & Inicial: & Inicial: & Inicial: & Inicial: & Inicial: \\
\hline & Final: & Final: & Final: $\quad 47,7$ & Final: & Final: & Final: \\
\hline \multirow[t]{2}{*}{3} & Inicial: & Inicial: & Inicial: 44,1 & Inicial: & Inicial: & Inicial: \\
\hline & Final: & Final: & Final: & Final: & Final: & Final: \\
\hline \multirow[t]{2}{*}{4} & Inicial: & Inicial: 46,4 & Inicial: & Inicial: 40,0 & Inicial: & Inicial: \\
\hline & Final: & Final: $\quad 43,5$ & Final: & Final: & Final: & Final: \\
\hline \multirow[t]{2}{*}{5} & Inicial: & Inicial: & Inicial: & Inicial: & Inicial: & Inicial: \\
\hline & Final: & Final: & Final: & Final: & Final: & Final: \\
\hline
\end{tabular}




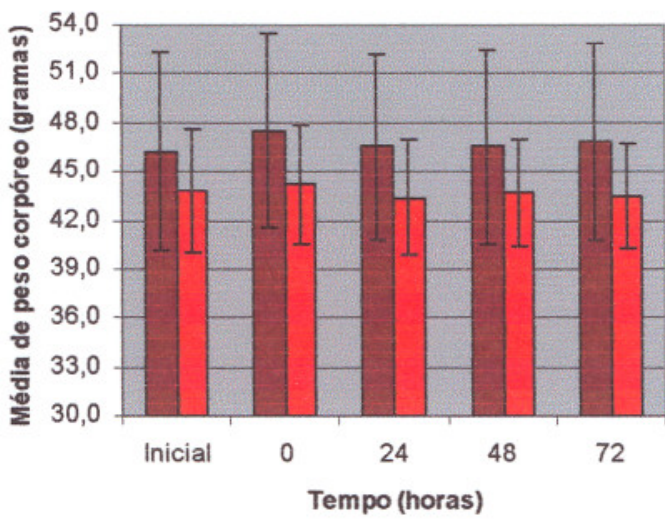

Extrato Polar

- Controle Polar

Figura 5.2 - Gráfico demonstrativo de perda e recuperação de peso dos camundongos submetidos ao ensaio de Toxicidade Sistêmica com extratos e controles polares.

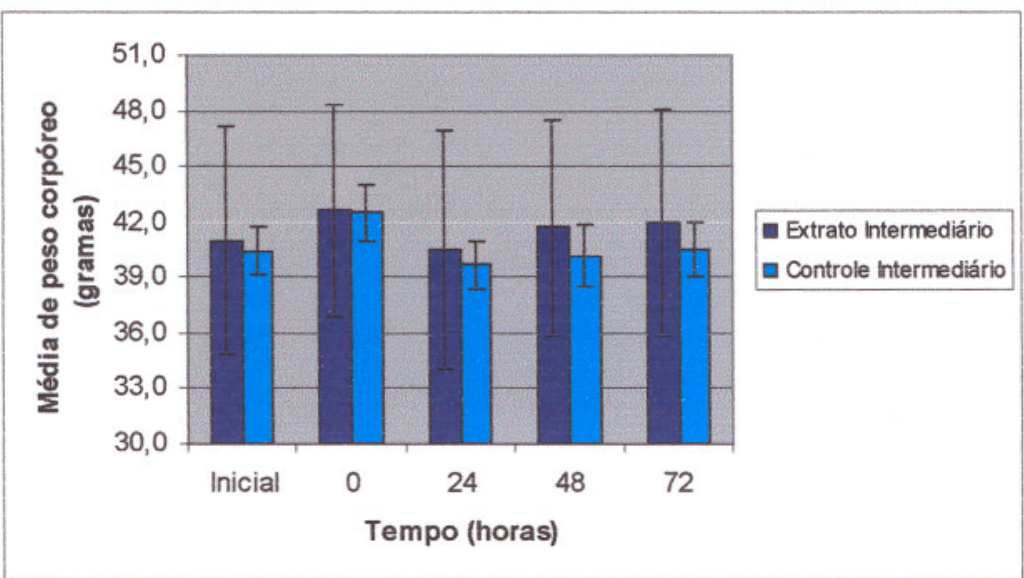

Figura 5.3 - Gráfico demonstrativo de perda e recuperação de peso dos camundongos submetidos ao ensaio de Toxicidade Sistêmica com extratos e controles intermediários.

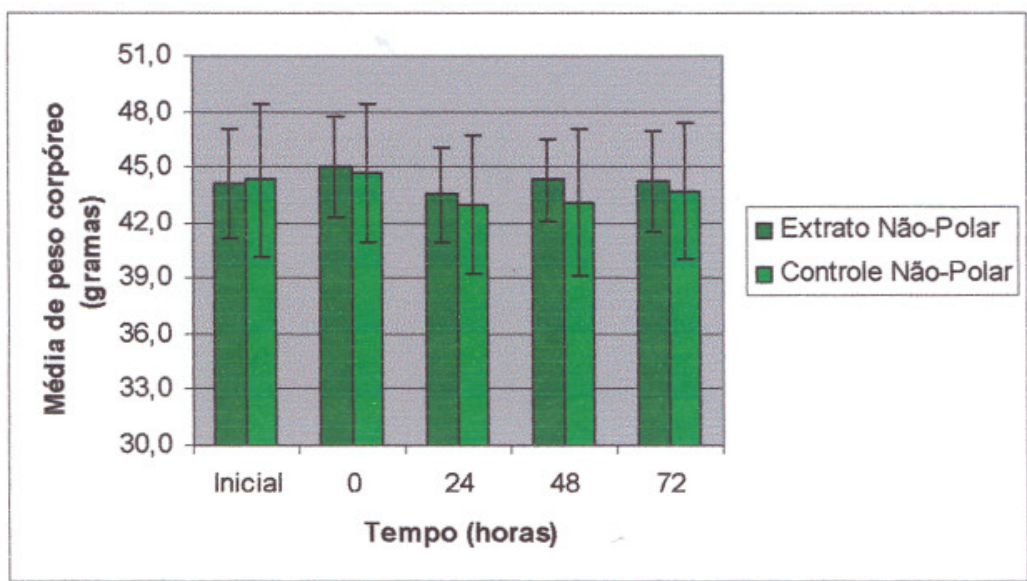

Figura 5.4 - Gráfico demonstrativo de perda e recuperação de peso dos camundongos submetidos ao ensaio de Toxicidade Sistêmica com extratos e controles não-polares. 


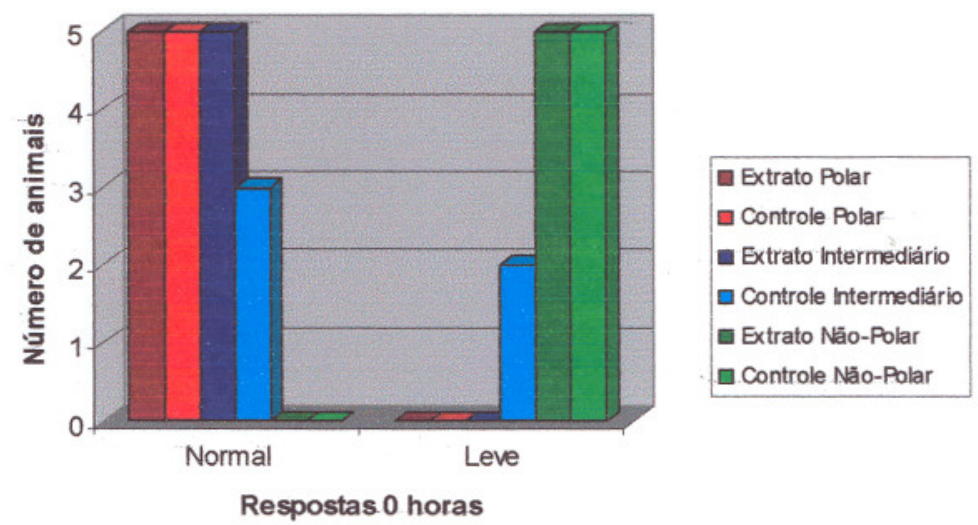

Figura 5.5 - Gráfico da observação comportamental em camundongos do ensaio de Toxicidade Sistêmica a 0 horas: Os animais inoculados com Controle Intermediário, Extrato e Controle Não-Polar apresentaram reações leves.

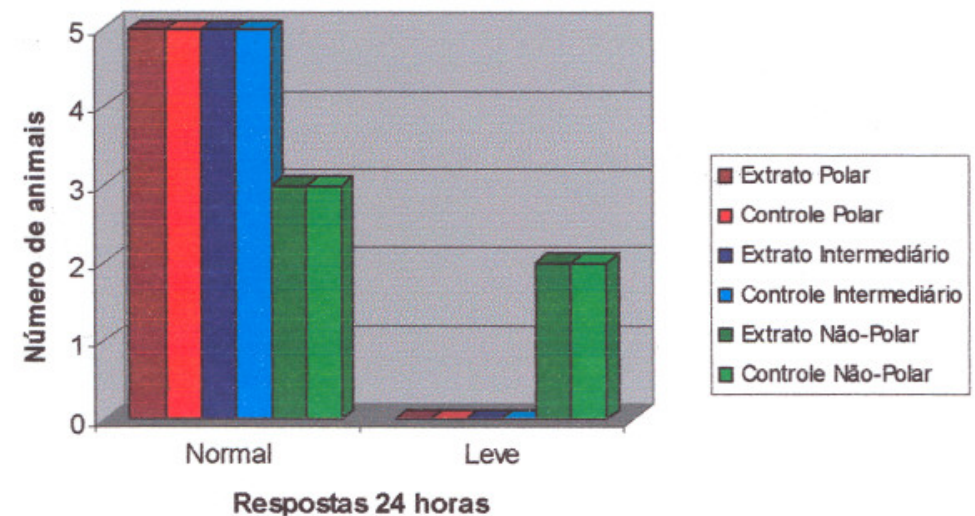

Figura 5.6 - Gráfico da observação comportamental em camundongos do ensaio de Toxicidade Sistêmica a 24 horas: Apenas alguns animais inoculados com Extrato e Controle Não-Polar apresentaram reações leves.

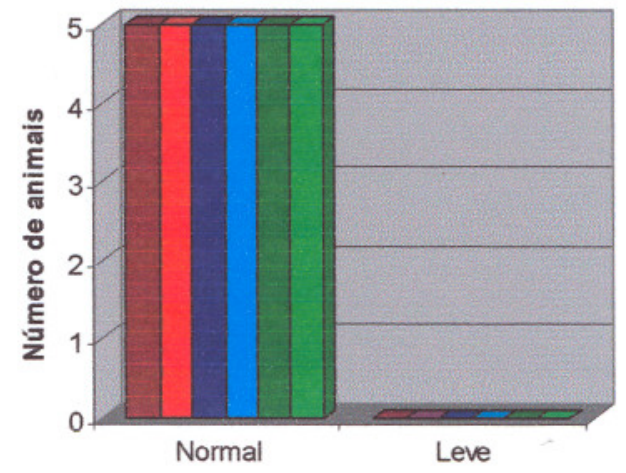

\begin{tabular}{|l|}
\hline Extrato Polar \\
- Controle Polar \\
— Extrato Intermediário \\
- Controle Intermediário \\
- Extrato Não-Polar \\
$\square$ Controle Năo-Polar \\
\hline
\end{tabular}

Respostas 48 e 72 horas

Figura 5.7 - Gráfico da observação comportamental em camundongos do ensaio de Toxicidade Sistêmica a 48 e 72 horas: Nesses tempos, todos os animais inoculados com todos os extratos e controles voltaram a normalidade, demonstrando ser o PVDF atóxico neste tipo de teste. 
Tabela 5.6 - Tabela de valores médios de peso corpóreo dos animais (g) e [ ] índice de toxicidade sistêmica para os grupos de animais conforme as das soluções ensaiadas.

\begin{tabular}{ccccccc}
\hline $\begin{array}{c}\text { Intervalo de } \\
\text { observações }\end{array}$ & EP & $\mathbf{C P}$ & EI & CI & EN & CN \\
\hline $\begin{array}{c}\text { Oh } \\
\text { índice }\end{array}$ & $47,50 \mathrm{~g}$ & $42,40 \mathrm{~g}$ & $46,56 \mathrm{~g}$ & $42,48 \mathrm{~g}$ & $45,20 \mathrm{~g}$ & $44,66 \mathrm{~g}$ \\
\hline $\mathbf{2 4 h}$ & {$[0]$} & {$[0]$} & {$[0,2]$} & {$[1]$} & {$[1]$} & {$[1]$} \\
\hline indice & $46,50 \mathrm{~g}$ & $43,25 \mathrm{~g}$ & $40,54 \mathrm{~g}$ & $39,70 \mathrm{~g}$ & $43,52 \mathrm{~g}$ & $42,96 \mathrm{~g}$ \\
\hline $\mathbf{4 8 h}$ & {$[0]$} & {$[0]$} & {$[0]$} & {$[0]$} & {$[1]$} & {$[1]$} \\
índice & $46,46 \mathrm{~g}$ & $43,98 \mathrm{~g}$ & $41,66 \mathrm{~g}$ & $40,24 \mathrm{~g}$ & $44,32 \mathrm{~g}$ & $43,06 \mathrm{~g}$ \\
\hline $\mathbf{7 2 h}$ & {$[0]$} & {$[0]$} & {$[0]$} & {$[0]$} & {$[0]$} & {$[0]$} \\
indice & $46,84 \mathrm{~g}$ & $43,55 \mathrm{~g}$ & $42,04 \mathrm{~g}$ & $40,52 \mathrm{~g}$ & $44,36 \mathrm{~g}$ & $43,66 \mathrm{~g}$ \\
\hline \multicolumn{0}{c}{} & {$[0]$} & {$[0]$} & {$[0]$} & {$[0]$} & {$[0]$} & {$[0]$} \\
\hline
\end{tabular}

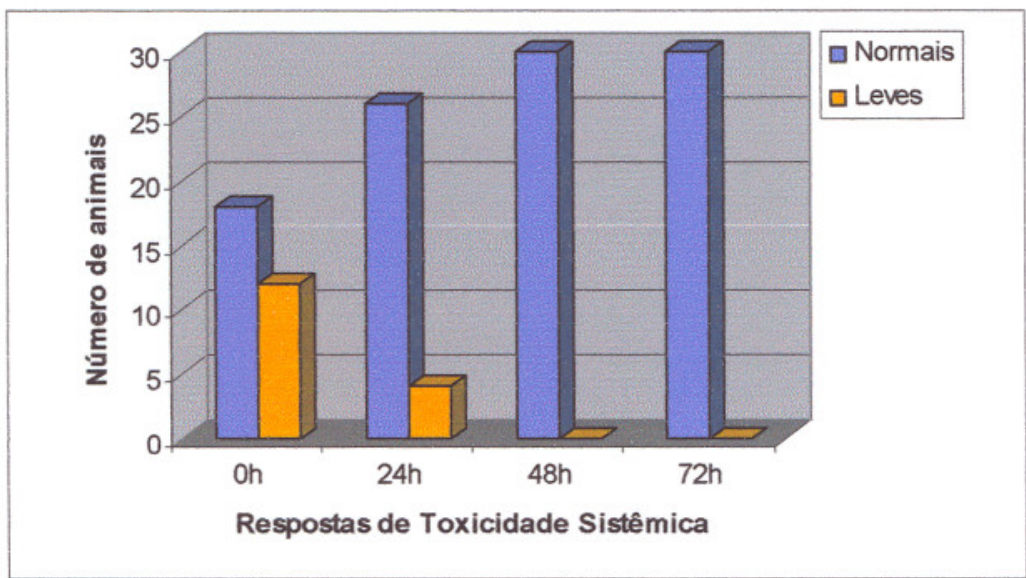

Figura 5.8 - Gráfico demonstrativo de recuperação ao estado de normalidade comportamental dos camundongos submetidos ao ensaio de Toxicidade Sistêmica após $\mathbf{7 2}$ horas. 


\subsection{Implante do PVDF}

Finalizando a dissecação e antes da extração das placas, macroscopicamente foi possível observar que algumas das tíbias que receberam os implantes de PVDF apresentaram crescimento de tecido ósseo (confirmado histológicamente) um pouco mais intenso quando comparado à tíbia com o implante da placa sem o polímero. Abaixo, na seqüência das imagens das Figuras 5.9, 5.10, 5.11, 5.12, pode-se verificar, nas imagens a esquerda, algumas das tíbias com o polímero e a direita, a outra tíbia, seus controles, sem o PVDF.

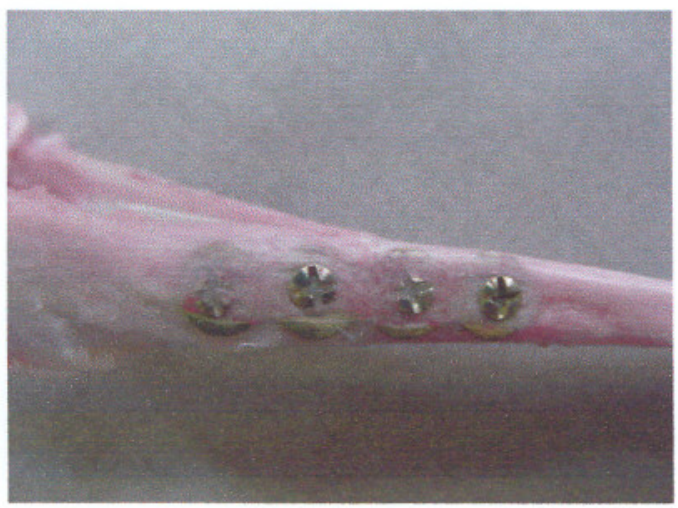

a)

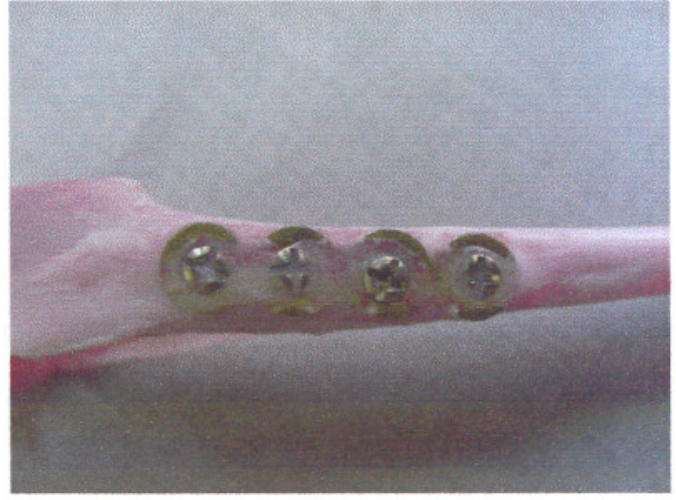

b)

Figura 5.9 - Tíbias de coelho, com e sem o PVDF, após trinta dias da data do implante: a) Tíbia direita com polímero e b) tíbia esquerda, controle, sem polímero. (coelho sem exercício físico).

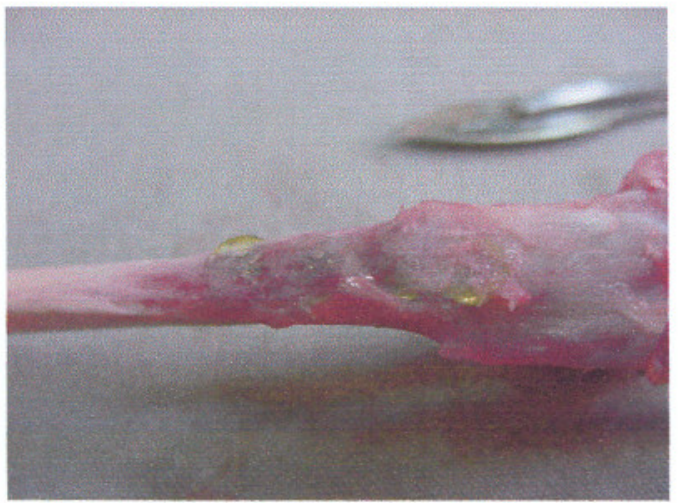

a)

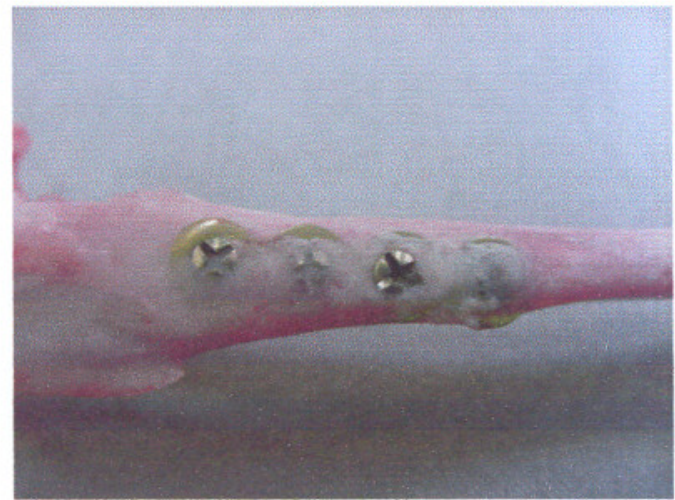

b)

Figura 5.10 - Tíbias de coelho, com e sem o PVDF, após trinta dias da data do implante: a) Tíbia esquerda com polímero e b) tíbia direita, controle, sem polímero. (coelho sem exercício físico). 


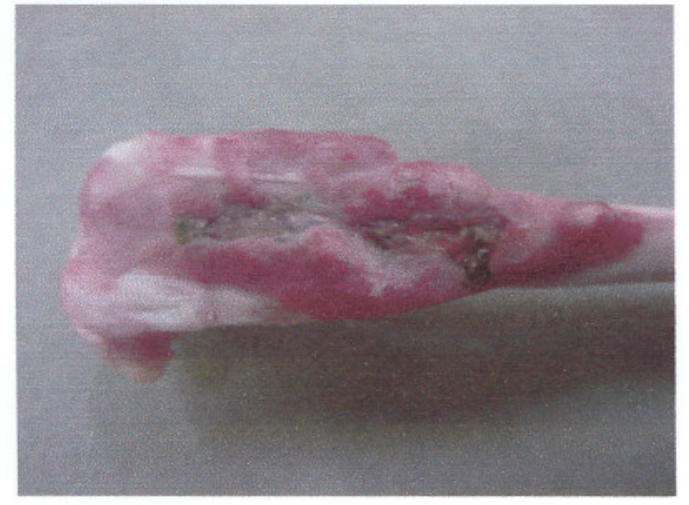

a)

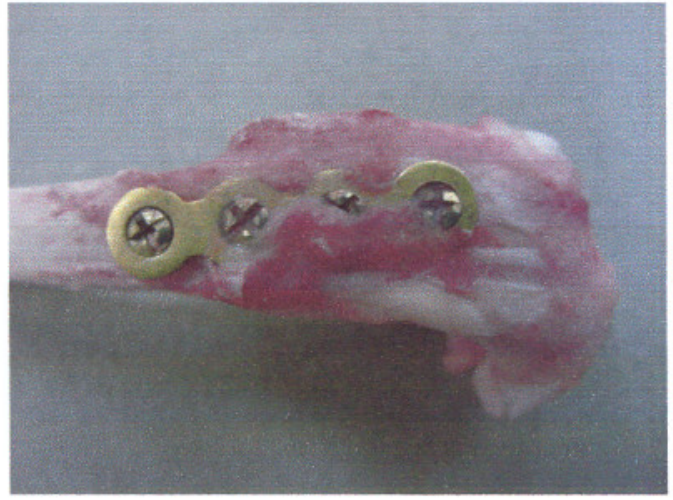

b)

Figura 5.11 - Tíbias de coelho, com e sem o PVDF, após trinta dias da data do implante: a)Tíbia esquerda com polímero e b) tíbia direita, controle, sem polímero. (coelho com exercício físico).

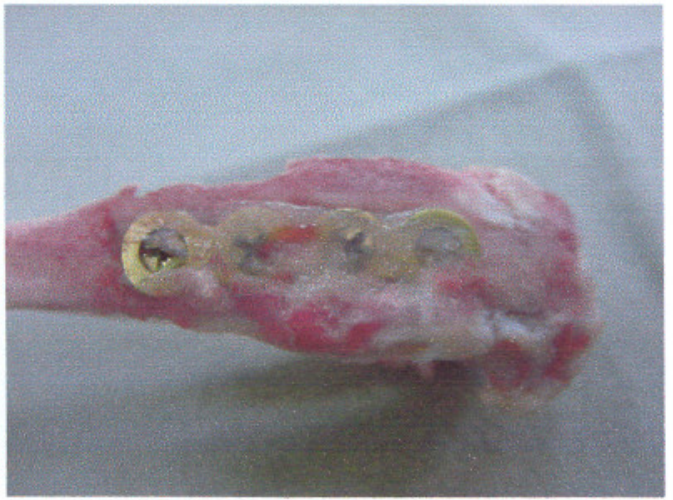

a)

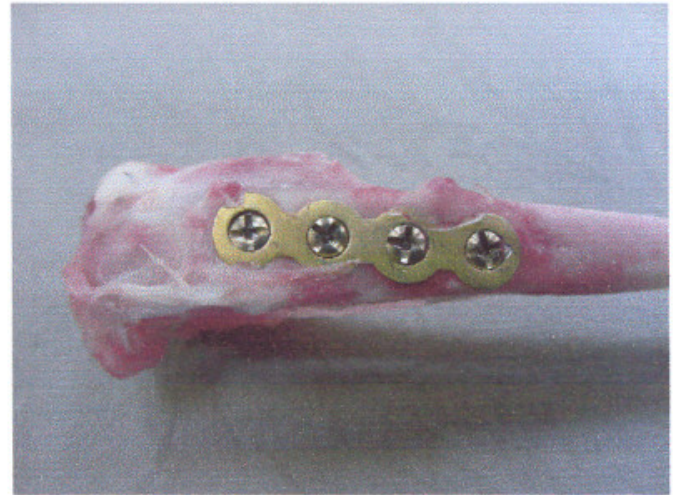

b)

Figura 5.12 - Tíbias com e sem o PVDF de alguns coelhos após trinta dias da data do implante: a) Tíbia direita com polímero e b) tíbia esquerda, controle, sem polímero. (coelho com exercício físico)

Em observações preliminares, pôde-se averiguar que em grande parte dos cortes histológicos das tíbias houve a ocorrência de regeneração óssea do local lesionado, o que já era esperado pela própria manutenção biológica do animal, porém, aproximadamente $65 \%$ das tíbias que receberam o polímero, apresentaram um preenchimento tecidual bastante intenso. Na Figura 5.13 é possível observar a lesão bem definida no seu contorno, mostrando a ocorrência de regeneração óssea em seu interior. 


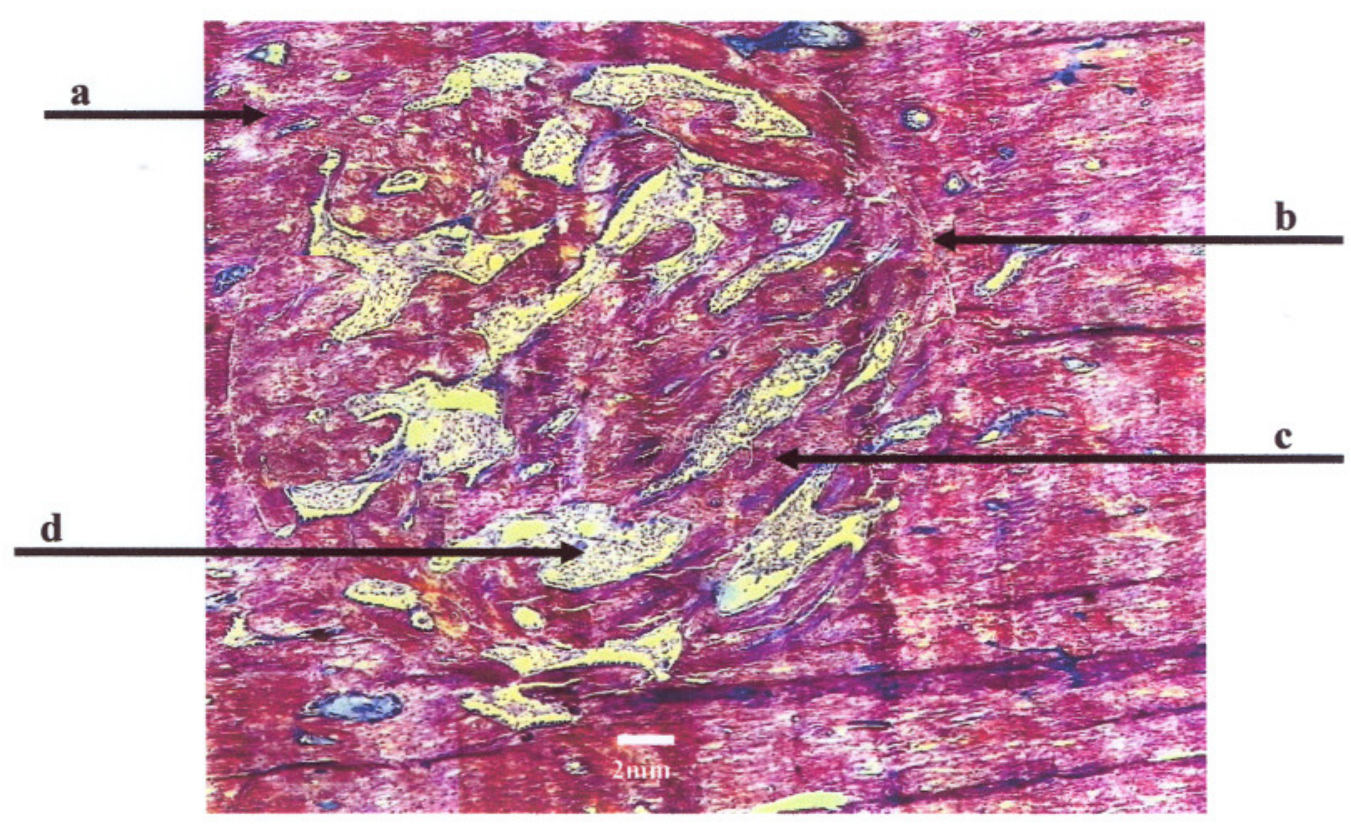

Figura 5.13 - Regeneração óssea: a) osso cortical; b) linha delimitante entre osso integro e início da regeneração óssea na lesão (provocada com broca de $2,5 \mathrm{~mm}$ de diâmetro); c) osso neoformado; d) medula e células fibrosas. Tecido ósseo leporino. Azul de toluidina. Calcificado. X40 (cada quadro).

\subsection{Análise estatística dos dados histomorfométricos}

Os valores obtidos após a coleta dos dados estão agrupados no Apêndice II (nas Tabelas de 19.1 a 19.18) e se referem aos índices histomorfométricos de área (T.Ar; Tb.Pf.Ar; B.Ar; O.Ar; Ma.Ar; Md.Ar; Fb.Ar - $\mathrm{mm}^{2}$ ); de volume (BV/TV; OV/BV - \%), de superfície (OS/BS; Ob.S/BS; ES/BS; Oc.S/BS - \%), de perímetro (Rm.Pm - mm) e de espessura (Tb.Th/ $\mu \mathrm{m} ; \mathrm{O} . \mathrm{Th} / \mu \mathrm{m})$ e numérico (Tb.Sp/ $\mu \mathrm{m}$; Tb.N/mm). A área tecidual medida foi em média $6,02 \mathrm{~mm}^{2}$. Tratamento estatístico foi aplicado devido a variabilidade entre indivíduos que podem ocorrer dentro de uma mesma espécie. Para as medidas pareadas e não paramétricas foi utilizado o teste de Wilcoxon unicaudal como teste estatístico (tíbias com e sem PVDF, tíbias com e sem PVDF - com exercício, e tíbias com e sem PVDF - sem exercício) e para as medidas não-pareadas e não-paramétricas, o teste de Mann-Whitney unicaudal (tíbias com e sem exercício - com PVDF e tíbias com e sem exercício - sem PVDF) As diferenças entre os diversos parâmetros analisados foram consideradas significantes para os valores de $\mathrm{P}<0,05$ (assinalados por '르" ') e não significantes para os valores de $\mathrm{P}>0,05$ (assinalados por " $n s$ "). Os gráficos (Figuras de 19.1 a 19.18 no Apêndice II) correspondem às médias dos grupos citados. Abaixo, a Tabela 5.7 mostra os resultados dos índices histomorfométricos analisados estatisticamente. 
Tabela 5.7 - Resultados estatísticos dos índices histomorfométricos.

\begin{tabular}{|c|c|c|c|c|c|c|c|c|c|c|}
\hline \multirow{4}{*}{ Índices Histomorfométricos } & \multicolumn{10}{|c|}{ Testes Estatísticos } \\
\hline & \multicolumn{4}{|c|}{ Entre tibias com e sem PVDF } & & & \multicolumn{4}{|c|}{$\begin{array}{l}\text { Mann-Whitney } \\
\text { Entre tíbias com e sem } \\
\text { exercício físico }\end{array}$} \\
\hline & \multicolumn{2}{|c|}{$\begin{array}{c}\text { Sem } \\
\text { exercício }\end{array}$} & \multicolumn{2}{|c|}{$\begin{array}{c}\text { Com } \\
\text { exercício }\end{array}$} & \multicolumn{2}{|c|}{$\begin{array}{c}\text { Com }+ \text { Sem } \\
\text { exercício }\end{array}$} & \multicolumn{2}{|c|}{$\begin{array}{l}\text { Com } \\
\text { PVDF }\end{array}$} & \multicolumn{2}{|c|}{$\begin{array}{c}\text { Sem } \\
\text { PVDF }\end{array}$} \\
\hline & $\mathrm{p}$ & ns & $\mathrm{p}$ & ns & $\mathrm{p}$ & ns & $\mathrm{p}$ & $\mathrm{ns}$ & $\mathrm{p}$ & ns \\
\hline Área óssea (B.Ar) & 0,03 & $*$ & 0,19 & ns & 0,02 & $\bar{*}$ & 1,20 & ns & 0,35 & ns \\
\hline Volume ósseo (BV/TV) & 0,01 & $x=$ & 0,23 & ns & 0,02 & * & 1,19 & ns & 0,50 & ns \\
\hline Área de osso mineralizado (Md.Ar) & 0,02 & $\Rightarrow$ & 0,23 & ns & 0,02 & * & 0,20 & ns & 0,39 & ns \\
\hline Área medular (Ma.Ar) & 0,04 & $*$ & 0,15 & ns & 0,02 & * & 0,20 & ns & 0,50 & ns \\
\hline Área osteóide (O.Ar) & 0,32 & ns & 0,23 & ns & 0,21 & ns & 0,17 & ns & 0,14 & ns \\
\hline Espessura osteóide (O.Th) & 0,27 & ns & 0,41 & ns & 0,23 & ns & 0,31 & ns & 0,43 & ns \\
\hline Superfície Osteóide (OS/BS) & 0,07 & ns & 0,23 & ns & 0,34 & ns & 0,35 & ns & 0,05 & $*$ \\
\hline Volume osteóide (OV/BV) & 0,07 & ns & 0,34 & ns & 0,21 & ns & 0,48 & ns & 1,12 & ns \\
\hline Superfície Osteoblástica (Ob.S/BS) & 0,10 & ns & 0,29 & ns & 0,28 & ns & 0,43 & ns & 0,02 & * \\
\hline Superfície Osteoclástica (Oc.S/BS) & 0,16 & ns & 0,29 & ns & 0,13 & ns & 0,23 & ns & 0,28 & ns \\
\hline Superficie de Reabsorção (ES/BS) & 0,32 & ns & 0,34 & ns & 0,24 & ns & 0,31 & ns & 0,48 & ns \\
\hline Área trabecular (Tb.Pf.Ar) & 0,05 & A & 0,23 & ns & 0,03 & $3^{2}$ & 0,17 & ns & 0,43 & ns \\
\hline Espessura trabecular (Tb.Th) & 0,02 & * & 0,08 & ns & 0,003 & $\star$ & 0,35 & ns & 0,43 & ns \\
\hline Número trabecular (Tb.N) & 0,19 & ns & 0,47 & ns & 0,21 & ns & 0,04 & $*$ & 0,35 & ns \\
\hline Separação trabecular (Tb.Sp) & 0,04 & $\neq$ & 0,34 & ns & 0,04 & $*$ & 0,06 & ns & 0,48 & ns \\
\hline Área de fibrose ( $\mathrm{Fb} . \mathrm{Ar})$ & 0,10 & ns & 0,15 & ns & 0,03 & * & 0,08 & ns & 0,43 & ns \\
\hline Volume fibrose (Fb.V/TV) & 0,23 & ns & 0,15 & ns & 0,07 & ns & 0,08 & ns & 0,27 & ns \\
\hline Perímetro de remodelamento ( $\mathrm{Rm} . \mathrm{Pm})$ & 0,47 & ns & 0,19 & ns & 0,40 & ns & 0,04 & * & 0,04 & $=$ \\
\hline
\end{tabular}

Wilcoxon - pareado, não paramétrico, unicaudal;

Mann-Witney - não pareado, não paramétrico, unicaudal.

$\mathbf{p}<\mathbf{0 , 0 5}=\quad=$ Significativo;

$\mathbf{p}>\mathbf{0 , 0 5}=\underline{n s}=$ Não Significativo

Os resultados dos parâmetros dinâmicos dos testes histomorfométricos não foram possíveis de serem observados devido a confluência ocorrida entre as duas marcações de tetraciclina. Isso pode ser explicado devido a rápida condição de reparo osso ocorrida nas lesões, fazendo com que as duas marcações ficassem com uma aparência "borrada" e sobrepostas.

\subsection{Análise morfológica - Histologia}

Em uma análise geral das lâminas, foi observado que os cortes apresentavam no sítio de análise, em sua maioria, tecido ósseo cortical e medular, com neoformação óssea caracterizada por trabéculas interligadas umas as outras. Entre essas trabéculas foi possível observar a formação de tecido mesenquimal frouxo, vascularizado e com uma quantidade de tecido hematopoiético variando em quantidade dependendo da amostra analisada. Alguns fragmentos analisados, onde a ossificação estava bem adiantada, foi possível observar atividade osteoclástica, o que veio a completar a modelagem e remodelagem óssea. Essa análise forneceu dados complementares aos dados quantitativos de histomorfometria, de forma que, foi possível observar, após as lâminas reindentificadas, que as tíbias que entraram 
em contato com o polímero e não foram submetidas aos exercícios físicos, apresentaram um número maior de trabéculas ósseas e, conseqüente, obturação do orifício, o que aponta, portanto, maior ossificação. A Tabela 5.8 apresenta os resultados obtidos pela análise morfologia e o laudo pode ser observado no Anexo I.

Tabela 5.8 - Tabela com os resultados obtidos através de análise morfológica em microscópio óptico. 0 dimensionamento da formação de trabéculas ósseas recebeu uma graduação entre $(+)$ e $(++++)$; o símbolo $(<+)$ representa uma formação extremamente baixa e (?) representa uma não identificação devido à perda de material biológico no ato da confecção da lâmina.

\begin{tabular}{|c|c|c|c|c|c|}
\hline & Lâmina $n^{\circ}$ & $\begin{array}{l}\text { Implante } \\
\text { de PVDF }\end{array}$ & Tíbia & Exercício & $\begin{array}{c}\text { Graduação de formação } \\
\text { de trabéculas ósseas }\end{array}$ \\
\hline \multirow[t]{2}{*}{ Coelho 07} & 31 & Sim & direita & Não & +++ \\
\hline & 32 & Não & esquerda & Não & ++ \\
\hline \multirow[t]{2}{*}{ Coelho 08} & 33 & Não & direita & Não & +++ \\
\hline & 34 & Sim & esquerda & Não & +++ \\
\hline \multirow[t]{2}{*}{ Coelho 09} & 1 & Não & direita & Não & ++ \\
\hline & 2 & Sim & esquerda & Não & +++ \\
\hline \multirow[t]{2}{*}{ Coelho 10} & 3 & Sim & direita & Sim & ++ \\
\hline & 4 & Não & esquerda & Sim & + \\
\hline \multirow[t]{2}{*}{ Coelho 11} & 5 & Não & direita & Sim & $<+$ \\
\hline & 6 & Sim & esquerda & Sim & $<+$ \\
\hline \multirow[t]{2}{*}{ Coelho 12} & 7 & Não & esquerda & Sim & ++ \\
\hline & 8 & Sim & direita & Sim & +++ \\
\hline \multirow[t]{2}{*}{ Coelho 13} & 9 & Sim & esquerda & Sim & ++ \\
\hline & 10 & Não & direita & Sim & + \\
\hline \multirow{2}{*}{ Coelho 14} & 11 & Sim & direita & Sim & ++ \\
\hline & 12 & Não & esquerda & Sim & +++ \\
\hline \multirow[t]{2}{*}{ Coelho 15} & 13 & Sim & esquerda & Não & ++1 \\
\hline & 14 & Não & direita & Não & +++1 \\
\hline \multirow[t]{2}{*}{ Coelho 16} & 15 & Sim & direita & Não & +++ \\
\hline & 16 & Não & esquerda & Não & ++ \\
\hline \multirow[t]{2}{*}{ Coelho 17} & 17 & Sim & esquerda & Não & +++ \\
\hline & 18 & Não & direita & Não & ++ \\
\hline \multirow[t]{2}{*}{ Coelho 18} & 19 & Sim & direita & Sim & $?$ \\
\hline & 20 & Não & esquerda & Sim & +++ \\
\hline \multirow[t]{2}{*}{ Coelho 19} & 21 & Sim & esquerda & Sim & +++ \\
\hline & 22 & Não & direita & Sim & +++ \\
\hline \multirow[t]{2}{*}{ Coelho 20} & 23 & Não & esquerda & Sim & + \\
\hline & 24 & Sim & direita & Sim & +++ \\
\hline \multirow[t]{2}{*}{ Coelho 21} & 25 & Não & direita & Não & $<+$ \\
\hline & 26 & Sim & esquerda & Não & +++1 \\
\hline \multirow[t]{2}{*}{ Coelho 22} & 27 & Sim & esquerda & Não & $<+$ \\
\hline & 28 & Não & direita & Não & + \\
\hline \multirow[t]{2}{*}{ Coelho 23} & 29 & Não & esquerda & Não & $<+$ \\
\hline & 30 & Sim & direita & Não & $<+$ \\
\hline
\end{tabular}




\subsection{Síntese dos resultados}

Portanto, dos resultados obtidos com os ensaios de esterilização, vê-se claramente na Tabela 5.1 e na Figura 5.1 que a técnica que trouxe a menor perda das propriedades piezelétricas foi o sistema por óxido de etileno. 0 erro de medida das amostras é de $5 \%$ e a perda de polarização pelo método esterilização por radiação também apresentou uma média de 5\%. Mesmo não sendo numericamente estatístico, pode-se observar que o polímero submetido ao processo de esterilização por óxido de etileno não apresentou perda alguma de sua polarização. Esse método de esterilização foi estendido as microretíficas, por conterem motores elétricos, enquanto que, para o restante dos instrumentais e dispositivos usados para a cirurgia, a autoclave supriu as necessidades requeridas.

Os teste de biocompatibilidade demonstraram ser o PVDF um polímero apto a ser implantado. $O$ teste de citotoxicidade, onde o PVDF foi exposto em contato com células de uma cultura, separado apenas por uma camada de ágar, não indicou nenhum processo de lise em tais células e nem alterou a zona em sua volta contendo corante vital, ou seja, o polímero não liberou nenhum componente tóxico quando comparado aos controles negativo (papel filtro atóxico) e positivo (látex tóxico). Este teste é um indicativo de que o PVDF é um material com alto índice de aceitação pelo organismo, apresentando uma excelente biocompatibilidade.

Tomando como base as Normas Técnicas ISO 10993 (partes 10 e 12) e a ASTM F719 e F749, que ditam alguns procedimentos e a forma de obtenção de resultados através da observação da formação de edemas e eritemas na derme do animal em experimento foi possível observar o polímero PVDF se apresentou como um material de baixíssima reação, sendo que os resultados de maior intensidade irritativa foram percebidos apenas nas primeiras 24 horas após a inoculação dos extratos e controles. Para as demais leituras (48 e 72 horas) os valores de mantiveram praticamente nulos. Edema um pouco mais acentuado ocorreu durante a primeira leitura do coelho classificado como Al (Tabela 18.1 do Apêndice I), para o controle Não-Polar (sem polímero), talvez pelo próprio procedimento de aplicação ou algum fator de sensibilidade ao óleo pelo próprio animal, (o que é previsto na norma) o que gerou um número negativo na Contagem de Irritação Primária para este animal, mas, como também pode ser observado na mesma tabela, para as demais leituras, nenhuma reação foi notada.

No cálculo do Índice de Irritação Primária, foram utilizados 5 animais, (que é o número mínimo que as Normas Técnicas sugerem) e pode ser observado um valor aproximado de 0,06 , o que é considerado negligencióvel pela norma (entre 0 a 0,4 observado 
na Tabela 4.4), demonstrando, portanto, ser esse polimero um material não-irritativo à derme.

O teste de toxicidade sistêmica também é um teste que utiliza a avaliação visual, que aliados a uma tabela fornecida pelas Normas ISO 10993-11 e ASTM F750, permite chegar a algum resultado conclusivo. Assim, o PVDF, aplicado intraperitonialmente em camundongos na forma de extrato, também não apresentou reações adversas nos animais, a não ser no momento da aplicação e nas primeiras 24 horas, o que é considerado normal, devido ao impacto da grande quantidade aplicada comparada com o tamanho do animal. Mesmo assim os camundongos mantiveram suas funções orgânicas normais, sem perder o apetite e sem o surgimento de qualquer tipo de prostração. Como podem ser observados nas Tabelas 5.5 e 5.6, os índices de reações adversas se mantiveram baixos e $90 \%$ dos animais chegaram ao seu peso inicial ou ganharam peso após 72 horas de ensaio. Se esse polímero apresentasse quaisquer produtos extraíveis tóxicos, esperar-se-ia que uma progressiva perda de peso acometesse os animais, fato esse que não ocorreu. Os gráficos da Figuras 5.2, $5.3 \mathrm{e}$ 5.4 demonstram a média dos pesos iniciais dos camundongos (antes da inoculação) e subseqüentes ganho de peso (após inoculação) e volta à normalidade. Nos gráficos das Figuras, 5.5, 5.6 e 5.7 pode-se ver a regressão dos estados de reações adversas observadas através do comportamento dos animais de leve para normal das inoculações com os Extratos e Controles Intermediários e Não-Polares durante as $\mathbf{7 2}$ horas percorridas de ensaio (sendo que as observaçõ்es nesse mesmo tempo para as inoculações dos Extratos e Controles Polares se apresentaram normais desde o início do teste). A Figura 5.8 demonstra o retorno ao quadro de normalidade dos animais depois das 72 horas percorridas. Nenhum animal veio a óbito devido aos extratos ou aos seus respectivos controles, quando corretamente preparados. Isto foi comentado devido a ocorrência da morte de dez camundongos em conseqüência a injeções inoculadas contendo Extrato e Controle Intermediários (solução etanol em salina fisiológica). Vale a pena ressaltar que essas amostras foram confeccionadas seguindo a Norma Técnica ISO 10.993-10, (1995-E) Annex B - Method for extraction of materials for biological tests, item B.2.10c que descreve "ethanol/saline", o que dá margem a um entendimento errôneo de uma diluição 1:1. A proporção indicada da solução intermediária para a realização desse tipo de teste foi encontrada na Pharmacopeia of United States of América (1995) - Biological Reactivity Tests, in vivo ${ }^{[64]}$, que determina uma diluição 1:20 ("1 in 20 solution of alcohol in sodium cloride injection"). Com a diluição adequada, foi possível dar andamento à avaliação da toxicidade sistêmica para o PVDF, provando novamente se tratar de um material atóxico. 
Embora sejam apenas complementos do trabalho, cita-se que a contenção anestésica, a técnica cirúrgica e os dispositivos empregados para a cirurgia (guia, microretífica, etc.) se mostraram bastante eficientes, possibilitando cirurgias rápidas e práticas. Não ocorreu um quadro sequer de contaminação durante ou depois das cirurgias graças aos cuidados de esterilização e éticos adotados. Houve a perda de dois coelhos por motivo de fratura em espiral no local do implante, o que causou a exposição do osso ao ambiente. Esses coelhos eram de pequeno porte (menos de $2,5 \mathrm{~kg}$ ) e não suportaram as cirurgias. Isso determinou que somente coelhos acima de $2,8 \mathrm{~kg}$ fossem usados para os ensaios.

Após dissecação das tíbias, pôde-se observar que algumas delas apresentaram um crescimento tecidual (que a olho nu sugeria tecido fibroso ou quando mais compacto, osso) sobre as placas. Foi constatado que era tecido ósseo através de exame histológico. As imagens da Figura 5.9a e 5.10a, demonstram esse crescimento, sendo um pouco mais acentuado nessas tíbias que receberam o implante de PVDF. Figuras $5.9 \mathrm{~b}$ e $5.10 \mathrm{~b}$ são os respectivos controles. Esses resultados foram extraídos de coelhos que não foram exercitados. Já nos coelhos das imagens 5.11a e 5.12a, que foram submetidos a exercício físico, apresentaram a mesma tendência, porém demonstrando que o exercício intensificou o crescimento tecidual nas duas situações (com e sem polímero). Os controles são respectivamente as Figuras $5.11 \mathrm{~b}$ e $5.12 \mathrm{~b}$

A Figura 5.13 mostra uma montagem feita com vários campos, onde se pode observar a lesão provocada na tíbia e seu reparo com osso neoformado, onde estruturas como faixas composta de osteoblastos e matriz osteóide podem ser visualizadas.

As Tabela de 5.7 mostra os resultados estatísticos dos dados histomorfométricos adquiridos das leituras das lâminas, demonstrando que, quando se trata de osso de uma forma geral, as médias de quantidade, área e porcentagem entre tíbias com e sem PVDF se mostraram significativas, indicando que as patas que receberam o polímero apresentaram um crescimento ósseo maior quando comparado ao seu controle. Isso pode ser bem evidenciado para os animais que não fizeram o exercício físico, enquanto que os animais que o fizeram apresentaram uma igualdade entre as patas com o implante de polímero e o controle. Como se tratavam de coelhos jovens machos, em pleno estado de crescimento, sem doença óssea ou metabólica alguma, pode-se tentar explicar que, ao serem submetidos a exercícios, suas atividades metabólicas superavam, em alguns casos, a atividade piezelétrica do polímero, ou seja, a recuperação biológica era mais rápida que a artificial, porém nos animais sedentários (se moviam apenas dentro da caixa de contenção) o polimero conseguiu demonstrar sua atividade. As análises histológicas, realizadas pelo especialista em anatomia patológica, também confirmaram esses dados. 
Entretanto, embora a quantidade óssea esteja maior para as tíbias implantadas com PVDF, pode-se observar que as outras estruturas ósseas como matriz osteóide, osteoclastos, osteoblastos e tecido fibroso permaneceram bastante próximos tanto no implante como no controle. Há um indicativo de que possivelmente a presença do polímero promova apenas uma aceleração no processo de ossificação e não uma maior produção de células sintetizadores de osso, demonstrado pela presença um pouco maior de células formadoras e de reabsorção nas patas que não tiveram contato com o polímero (Tabelas 19.9 e 19.10 e Figuras 19.9 e 19.10 do Apêndice II). Sendo assim o polímero talvez promova um estímulo aos osteoblastos em acelerar a produção de matriz e não um aumento de produção dessas células. Tal estímulo se mostra coerente, visto que é sabido que osteoblastos respondem a estimulação elétrica e, filmes piezelétricos deformados, desenvolvem potenciais elétricos. ${ }^{[25,35,38]}$

As Figuras de 19.1 até 19.18 do Apêndice $I I$ mostram gráficos com as médias obtidas dos resultados histomorfométricos, permitindo uma melhor observação dos resultados.

Como o método de histomorfometria é utilizado para análises do comportamento de remodelagem óssea normal ou em enfermidades como osteoporose, osteopenia, osteíte fibrosa, entre outras, onde a remodelagem óssea de alguma forma se encontra comprometida, ou no mínimo normal, não foi possível observar as marcações de tetraciclina em ossos, onde o metabolismo está perfeito (trata-se de coelhos machos jovens, evidentemente em crescimento e sãos) e que, num processo de reparação óssea, como, por exemplo, em uma fratura, esse jovem organismo promove uma recuperação que acontece de maneira bastante rápida para sanar a lesão. Essa velocidade acaba por interferir nas marcações de tetraciclina, pois o osso primário (woven bone) tem a característica de crescer rápida $\mathrm{e}$ desordenadamente. ${ }^{[26,29,83]}$

A esteira ergométrica adaptada para os exercícios físicos dos coelhos, na tentativa de estimular mecanicamente o PVDF, também se mostrou muito eficiente, alcançando aos propósitos para o qual foi montada. Entretanto, quando o exercício fisico se fez presente nos coelhos, o efeito do PVDF sobre o osso praticamente foi anulado, como pode ser observado nos gráficos histomorfométricos. Aparentemente, em situações onde estímulos mecânicos naturalmente aplicados (como o caso do exercício), o osso responde numa maior velocidade que o efeito piezelétrico do polimero (não esquecendo que o modelo utilizado foi coelhos machos jovens, em pleno desenvolvimento e sem nenhum quadro de doença osteometabólica). Supondo uma aplicação em pacientes humanos (pois muito ainda precisa ser feito para que se chegar a este estágio) o polímero seria uma boa alternativa de promoção óssea a pacientes impossibilitados da realização de exercícios físicos 


\section{Conclusões}

O processo de esterilização por óxido de etileno mostrou ser o método mais eficiente para a conservação da polarização do PVDF.

Os ensaios de desempenho biológico, representado pelos testes de citotoxicidade, sensibilidade intracutânea e toxicidade sistêmica, demonstraram ser o PVDF um material biocompatível, podendo ser implantado sem o perigo da liberação de elementos tóxicos.

A técnica cirúrgica aplicada, assim como os dispositivos utilizados, o sistema de esterilização desses dispositivos; a assepsia pré-operatória pessoal e do coelho, (o que resultou em $0 \%$ de contaminação/infecção) e as doses de anestésicos e antibióticos utilizadas, proporcionaram cirurgias rápidas e seguras.

O sistema de análise por histomorfometria demonstrou ser um método bastante eficiente, apresentando a possibilidade de sua utilização como método diagnóstico de crescimento ósseo em pesquisas envolvendo biomateriais. (não se discute seu já consagrado uso para doenças osteometabólicas). Neste trabalho, esse método demonstrou claramente a atividade de crescimento ósseo diferenciada para as lesões que entraram em contato com o PVDF. Análises morfológicas também forneceram os mesmos resultados

Quando estimulado com exercícios físicos, foi possível observar que o metabolismo ósseo inerente de um coelho macho, jovem, e, em condições normais de saúde superou a atividade piezelétrica do osso, colocando o reparo da lesão, tanto na pata controle como na que recebeu PVDF nas mesmas condições de recuperação.

Embora ainda seja um estudo inicial sobre o efeito do polímero na restauração mais acelerada de lesões ósseas através do efeito piezelétrico, pode-se perceber que existe uma diferença significativa no crescimento de tecido ósseo nas tíbias que receberam o PVDF. 


\section{Sugestōes para Tra6alfos Futuros}

- Utilizar a implante do polímero PVDF utilizando fêmeas, onde seria possível provocar uma osteoporose, através da retirada dos ovários, e verificar o efeito piezelétrico do polímero sobre a osteogênese;

- Associar uma estimulação ultra-sônica externa, verificando se essas ondas de choque podem potencializar o efeito piezelétrico do PVDF implantado;

- Rever o modelo animal, adotando, por exemplo, suinos, como animal de experimento, onde a tíbia sofre compressão e não flexão como no caso do coelho.

- Rever uma outra estratégia de fixação do polímero ao dispositivo de osteossíntese.

- Comparar se o polímero PVDF sem polarização atua também de forma positiva no crescimento ósseo quando comparado com polímeros polarizados e controle (sem polímero);

- Verificar se a espessura do filme, de alguma forma causa alguma influência sobre o crescimento ósseo.

- Verificar as possibilidades de prender o polímero à placa de osteossíntese ou desenvolver um dispositivo com o PVDF que não seja dependente da placa para sua fixação. 


\section{Anexo $\mathcal{A}$}

8.1. Aprovação do Projeto de Trabalho pela Comissão de Ética para Análise de Projetos de Pesquisa do Hospital das Clínicas da Faculdade de Medicina da Universidade de São Paulo.

\section{Comissão de Ética para Análise de Projetos de Pesquisa}

\section{APROVAÇÃO}

A Comissão de Ética para Análise de Projetos de Pesquisa - CAPPesq da Diretoria Clínica do Hospital das Clínicas e da Faculdade de Medicina da Universidade de São Paulo, em sessão de 28-09-2000, APROVOU o Protocolo de Pesquisa $n^{\circ} 738 / 00$ intitulado: "Estudo da utilização de polímeros piezelétricos em materiais para implantes ortopédicos", apresentado pelo(a) pesquisador(a) Dr. André Luís Paschoal, do Departamento de Ortopedia e Traumatologia.

CAPPesq, 29 de Setembro de 2000.

PROF. DRL JORGE KALIL FILHO

Presidente da Comissão de Ética Para

Análise de Projetos de Pesquisa

OBSERVAÇÃO: Cabe ao pesquisador elaborar e apresentar à CAPPesq, os relatórios parciais e final sobre a pesquisa (Resoluçấo do Conselho Nacional de Saúde $n^{\circ} 196$, de 10.10.1996, inciso IX.2, letra "c"). 


\title{
9. Anexo $B$
}

\subsection{Laudo do Teste de Citotoxicidade emitido pelo Adolfo Lutz.}

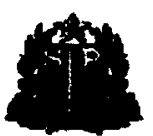

\author{
SECRETARIA DE ESTADO DA SAÚDE \\ INSTITUTO ADOLFO LUTZ \\ SEÇÃO DE CULTURAS CELULARES
}

\section{AVALIAÇÃO DO POTENCIAL DE CITOTOXICIDADE IN VTTRO}

\author{
METODO DB DIRUSXO FM AGAR
}

LINHAGEM CELULAR: NCTC Clone $92 \%$ de tecido conjunivo de camundongo (CCL1ATCC), 8 so semeadas em placas de Petri e incubadas por 48 horas. 0 meio de cultura llquido substifuido pelo meio de cobertura $\$ 6$ lldo que composto de partes iguais de meio $2 x$ concentrado e agar com vermetho neutro. As amostras sáo colocadas sobre esse meio de cobertura $e$ as placas novamente incubadas por 24 horas. Observa-se o indice de zona (IZ) que a área náa corada pelo corante vital e, anota-se o indice de lise (IL) que indica a porcentagem de células degeneradas.

Ambos 08 indices sâo numericamente anotados relacionados, dando 0 indice de resposta (IR). As amostras sáo testadas e quadruplicadas em placas separadas.

\begin{tabular}{|c|l|r|}
\hline $\mathbf{2}$ & \multicolumn{1}{|c|}{ DBSCRICXO } & CLASSIICACIO \\
\hline 0 & Nenhuma Zona sob e ao redor da amostra & Nenhuma \\
\hline 1 & Zona limitada sob a amostra & Leve \\
\hline 2 & Zona menor que $0,5 \mathrm{~cm}$ ao redor da amostra & Suave \\
\hline 3 & Zona entre $0,5-1,0 \mathrm{~cm}$ go redor da amostra & Moderada \\
\hline 4 & Zona maior que $1,0 \mathrm{~cm}$ genvolver toda placa & Severa \\
\hline 5 & Zona que envolve toda placa & \\
\hline
\end{tabular}

\begin{tabular}{|c|c|c|}
\hline II. & DESCRICAO & CLASSEICACXO \\
\hline 0 & Nenhuma lise & Nenhuma \\
\hline 1 & Menos de $20 \%$ da Zons a fetada & Leve \\
\hline 2 & Menos do $40 \%$ da Zona afotada & Suave \\
\hline 3 & Menos de $60 \%$ da Zonn afotade & Modereda \\
\hline 4 & Menos de $80 \%$ da Zona afetada & \multirow[t]{2}{*}{ Severa } \\
\hline 5 & Mais de $80 \%$ da Zone afetada & \\
\hline
\end{tabular}

Amostras sólidas: sâo colocadas diretamente sobre o melo de cobertura.

Amostras em pó:sáo colocadas dentro de 1 cillndro fuado sobre o meio de cobertura Amostras lípuldas:diaco de papel de fillo aloxico sáo embebldos com a amostra e colocados sobre o meio de cobertura.

Amostras submetidas à extração:A relaç⿰o da área de superficio do maierial o o volume do veiculo de extraço nso deve ser maior que $6 \mathrm{~cm}^{2} / \mathrm{ml}$ - menor do que $0,5 \mathrm{~cm}^{2} / \mathrm{ml}$. Quando a superficie da amostra for indeterminada pesar de $0,1-0,2 \mathrm{~g} / \mathrm{ml}$. Os vefculos de extraçăo unllizados sáo solucta saline ou oleo de semente de algodso.As condiços de extraçáo recomendadas sa $50^{\circ} \mathrm{C}-72 \mathrm{hs}$ ou $70^{\circ} \mathrm{C}-24 \mathrm{hs}$. Embeber o extrato om discos de papel de ritro e colocar sobre o meio de coberture.

Controle posituva:tragmento de $0,5 \mathrm{~cm} \times 0,5 \mathrm{~cm}$ de tátex toxico

Controle negatlvo:discos de papel de fitro atóxico $\operatorname{com} 0,5 \mathrm{~cm}$ de diámetro

Bbllografla: ASTM F895-84:1984-Siandard lest mothod for agar difiusion cell culure screening for cytotoxicily ISO 10993.5:1992-Blological evaluation for medical devices tests for cytoloxicily: in vitro methods US Pharmacopeia XXIII,1995-Biological reactivily lests in vitro 


\section{AVALIAÇĀO DO POTENCIAL DE CITOTOXICIDADE IN VITRO}

Requiaitante: Universidade de São Paulo Escola de Engenharia de Sta CarlosDepartamento de Materials,Aéronautica e Automoblistica

Endereço: Av. Cartos Botelho, n 1465

AC: Lauralice de Campos F.Canale

Amostras Teste: $n^{\bullet} 2284$ - livro teste $V$ - pag.136

Nome da(s) Amostra(s):

a) FQme de Polfmero do Tipo PVF 2

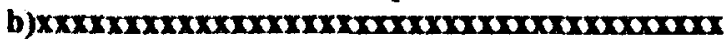

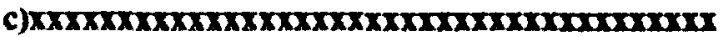

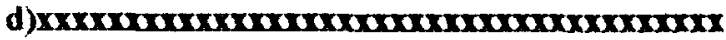

ANALISE DB ORENTACXO: 2256

PROCESSO N: 5.286 (23.08.99)

\begin{tabular}{|c|c|c|c|c|c|c|c|c|c|c|c|c|}
\hline \multirow{3}{*}{ AMOSTRA: } & \multicolumn{12}{|c|}{$\begin{array}{l}\text { RISTITADOS OBTDOS HA LFITURA DAS PLACAS DE } \\
\text { COLTURA CLEULARE }\end{array}$} \\
\hline & \multicolumn{3}{|c|}{$N^{0} 1$} & \multicolumn{3}{|c|}{$N^{0} 2$} & \multicolumn{3}{|c|}{$N^{0} 3$} & \multicolumn{3}{|c|}{$N^{0} 4$} \\
\hline & $\mathbf{E}$ & $\boldsymbol{L}$ & $\mathbf{I R}$ & II. & I. & $\mathbf{I}$ & $\boldsymbol{E}$ & $\mathbf{n}$ & $\mathbf{I R}$ & $\mathbf{V}$ & II & IR \\
\hline 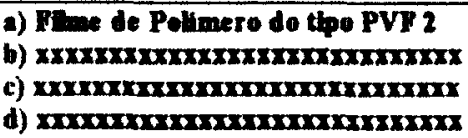 & $\frac{1}{x x}$ & $\begin{array}{l}6 \\
x x \\
x x\end{array}$ & $\begin{array}{l}0 / 0 \\
\mathbf{x x}\end{array}$ & $\begin{array}{l}0 \\
\mathbf{x x} \\
\mathbf{x x}\end{array}$ & $\begin{array}{l}\mathbf{x} \\
\mathbf{x x}\end{array}$ & $\begin{array}{l}9 / 0 \\
\mathbf{x x} \\
\mathbf{x x}\end{array}$ & $\begin{array}{l}0 \\
\mathbf{x x} \\
\mathbf{x x}\end{array}$ & $\begin{array}{l}0 \\
\mathbf{x x} \\
\mathbf{x x}\end{array}$ & $\begin{array}{l}0 / 0 \\
\mathbf{x x} \\
\mathbf{x x} \\
\mathbf{x x}\end{array}$ & $\begin{array}{l}0 \\
\mathbf{x x} \\
\mathbf{x x}\end{array}$ & $\begin{array}{l}0 \\
\mathbf{x x} \\
\mathbf{x x}\end{array}$ & $\begin{array}{l}0 / 6 \\
\mathbf{x x} \\
\mathrm{Xx} \\
\mathbf{x x}\end{array}$ \\
\hline $\begin{array}{l}\text {-Controle Negattro } \\
\text {-Coutrole Positivo }\end{array}$ & $\begin{array}{l}0 \\
5\end{array}$ & $\begin{array}{l}\mathbf{0} \\
3\end{array}$ & $\begin{array}{l}0 / 0 \\
5 / 3\end{array}$ & 5 & 3 & $\begin{array}{l}0 / 0 \\
5 / 3\end{array}$ & $\begin{array}{l}0 \\
5\end{array}$ & $\begin{array}{l}0 \\
3\end{array}$ & $\begin{array}{l}0 / 6 \\
5 / 3\end{array}$ & 5 & $\begin{array}{l}0 \\
3\end{array}$ & $\begin{array}{l}10 \\
5 / 3\end{array}$ \\
\hline
\end{tabular}

concLusAo: A amostra $n^{\circ} 2284$ quando testada nåo apresentou eféto tóxico para a tinhagem celular NCTC done 929 (CCL-1, ATCC-USA).

Säo Paulo, 26 de agosto de 1999

Tamiko seblawa Hed

Tam iko Ichikawa lkeda Ass.Tecnico.de Apoio d Pesq.Cientifica e Tecmologice RG. $9.808 .180-0$
Dra Auree Silhoira Cruz Chefo da Septo de Cult.Celulare RG.8.367.437 
10. Anexo $C$

\subsection{Planilha de Anotações - Sensibilidade Intracutánea}

Tabela 10.1- Planilha de anotações das reações para o teste de sensibilidade intracutânea

Animal data

\begin{tabular}{|c|c|c|c|c|c|c|c|c|}
\hline & \multicolumn{2}{|c|}{$\begin{array}{l}\text { Extrato } \\
\text { Polar }\end{array}$} & \multicolumn{2}{|c|}{$\begin{array}{l}\text { Extrato } \\
\text { Não-Polar }\end{array}$} & \multicolumn{2}{|c|}{$\begin{array}{l}\text { Solvente } \\
\text { Polar }\end{array}$} & \multicolumn{2}{|c|}{$\begin{array}{l}\text { Solvente } \\
\text { Não Polar }\end{array}$} \\
\hline & Eritema & Edema & Eritema & Edema & Eritema & Edema & Eritema & Edema \\
\hline \multirow{4}{*}{24 Horas } & & & & 2 & & & & \\
\hline & & & & 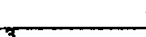 & 8 & & & \\
\hline & & 4 & $\pi$ & 4 & 19 & 9 & 9 & 8 \\
\hline & 5 & & 5 & 5 & T0 & 10 & $\pi$ & To \\
\hline \multirow{4}{*}{48 horas } & & 2 & 2 & 2 & & & & \\
\hline & 3 & 3 & 13 & & 8 & & & \\
\hline & & $\pi$ & 4 & 4 & & 8 & 9 & 9 \\
\hline & & 5 & 5 & 5 & To & 10 & To & 30 \\
\hline \multirow{4}{*}{$\begin{array}{c}72 \\
\text { horas }\end{array}$} & 2 & 2 & $\sqrt{2}$ & & & & & \\
\hline & & & 3 & & & & & \\
\hline & & $\pi$ & 4 & 4 & 9 & o & F & 9 \\
\hline & 5 & 5 & 5 & 5 & To & 10 & \% & r \\
\hline \multicolumn{9}{|l|}{ Total } \\
\hline \multirow{2}{*}{$\begin{array}{c}\text { Divide pelo } \\
\text { número de } \\
\text { observaçós }\end{array}$} & $-15=$ & $-15=$ & $-: 15=$ & $-15=$ & $-15=$ & $-: 15=$ & $-15=$ & $-15=$ \\
\hline & & & & & & & & \\
\hline \multirow{6}{*}{ Somas } & \multicolumn{4}{|c|}{ Soma dos eritemas dos extratos } & \multicolumn{4}{|c|}{ Soma dos eritemas dos solventes } \\
\hline & \multicolumn{2}{|c|}{+} & $=$ & & & + & $=$ & \\
\hline & \multicolumn{4}{|c|}{ Soma dos edemas dos extratos } & \multicolumn{4}{|c|}{ Soma dos eritemas dos extratos } \\
\hline & \multicolumn{2}{|c|}{+} & $=$ & & & + & $=$ & \\
\hline & \multicolumn{4}{|c|}{$\begin{array}{c}\text { Soma dos edemas e eritemas dos } \\
\text { extratos }\end{array}$} & \multicolumn{4}{|c|}{$\begin{array}{l}\text { Soma dos edemas e eritemas dos } \\
\text { solventes }\end{array}$} \\
\hline & \multicolumn{4}{|c|}{$=$} & & + & \multicolumn{2}{|l|}{$=$} \\
\hline \multirow{2}{*}{\multicolumn{2}{|c|}{$\begin{array}{c}\text { Subtração } \\
\text { Extrato - Solvente. }\end{array}$}} & \multicolumn{5}{|c|}{ Contagem de Irritação Primária para A1 } & & \\
\hline & & CIP & $=$ & - & $=$ & & & \\
\hline
\end{tabular}


10.2. Exemplo do procedimento do cálculo para obtenção da Contagem de Irritação Primária e Índice de Irritação Primária para o Teste se Sensibilidade Intracutânea com animais hipotéticos.

Tabela 10.2 - Exemplo de planilha utilizada para Contagem de Irritação Primária

\begin{tabular}{|c|c|c|c|c|c|c|c|c|}
\hline & \multicolumn{2}{|c|}{$\begin{array}{l}\text { Extrato } \\
\text { Polar }\end{array}$} & \multicolumn{2}{|c|}{$\begin{array}{l}\text { Extrato } \\
\text { Não-Polar }\end{array}$} & \multicolumn{2}{|c|}{$\begin{array}{l}\text { Solvente } \\
\text { Polar }\end{array}$} & \multicolumn{2}{|c|}{$\begin{array}{l}\text { Solvente } \\
\text { Não Polar }\end{array}$} \\
\hline & $\begin{array}{l}\text { Eritem } \\
\text { a }\end{array}$ & $\begin{array}{c}\text { Edem } \\
\mathbf{a}\end{array}$ & $\begin{array}{l}\text { Eritem } \\
\text { a }\end{array}$ & Edema & $\begin{array}{l}\text { Eritem } \\
\quad \mathbf{a}\end{array}$ & Edema & $\begin{array}{l}\text { Eritem } \\
\text { a }\end{array}$ & Edema \\
\hline \multirow{5}{*}{24 Horas } & $1-0$ & $1-1$ & $1-1$ & $1-0$ & $6-0$ & $6-1$ & $6-0$ & $6-0$ \\
\hline & $2=1$ & $2-2$ & $2-2$ & $2-1$ & $7-1$ & $7=0$ & $7-2$ & $7-1$ \\
\hline & $3-1$ & $3-1$ & $3-1$ & $3-1$ & $8-0$ & $8-1$ & $8-1$ & $8-0$ \\
\hline & $4-2$ & $4-2$ & $4-2$ & $4-2$ & $9-2$ & $9-0$ & $9-2$ & $9-2$ \\
\hline & $5-1$ & $5-1$ & $5-1$ & $5-1$ & $10-0$ & $10-0$ & $10-0$ & $10^{-0} 0$ \\
\hline \multirow{5}{*}{48 horas } & $1-1$ & $1-1$ & $1-0$ & $1-0$ & $6-1$ & $6-0$ & $6-0$ & $6-1$ \\
\hline & $2-1$ & $2=0$ & $2=0$ & $2-1$ & $7=0$ & $7-0$ & $7-0$ & $7=0$ \\
\hline & $3-1$ & $3-1$ & $3-1$ & $3-1$ & $8-1$ & $8-1$ & $8-1$ & $8-1$ \\
\hline & $4=0$ & $4-0$ & $4-1$ & $4-2$ & $9-0$ & $9-0$ & $9-0$ & $9-0$ \\
\hline & $5=0$ & $5-0$ & $5-0$ & $5-1$ & $10-0$ & $10-0$ & $10-1$ & $10-0$ \\
\hline \multirow{5}{*}{ 72horas } & $1-0$ & $1-1$ & $1-1$ & $1-0$ & $6-1$ & $6-0$ & 6.0 & $6-0$ \\
\hline & $2-0$ & $2-0$ & $2-0$ & $2-0$ & $7-0$ & $7=0$ & $7-0$ & $7-0$ \\
\hline & $3-1$ & $3-1$ & $3-1$ & $3-1$ & $8-1$ & $8-1$ & $8-1$ & $8-1$ \\
\hline & $4-0$ & ${ }_{4}-0$ & $4-0$ & $4-1$ & $9-0$ & $9-0$ & $9-0$ & $9-0$ \\
\hline & $5=0$ & $5=0$ & $5-0$ & $5-0$ & $10=0$ & $10-1$ & $10-0$ & $10=0$ \\
\hline Total & 9 & 10 & 11 & 14 & 7 & 5 & 8 & 6 \\
\hline $\begin{array}{c}\text { Divide pelo } \\
\text { número de } \\
\text { observaçőes }\end{array}$ & $\begin{array}{c}9: 15= \\
0,60\end{array}$ & $\begin{array}{l}10: 15 \\
= \\
0.66\end{array}$ & $\begin{array}{c}11: 15= \\
0,73\end{array}$ & $\begin{array}{c}14: 15= \\
0,93\end{array}$ & $\begin{array}{c}7: 15= \\
0,46\end{array}$ & $\begin{array}{c}5: 15= \\
0,33\end{array}$ & $\begin{array}{c}8: 15= \\
0,53\end{array}$ & $\begin{array}{c}6: 15= \\
0,40\end{array}$ \\
\hline \multirow{3}{*}{ Somas } & \multicolumn{4}{|c|}{$\begin{array}{l}\text { Soma dos eritemas dos extratos } \\
\qquad 0,60+0,73=1,33\end{array}$} & \multicolumn{4}{|c|}{$\begin{array}{l}\text { Soma dos eritemas dos solventes } \\
\qquad 0,46+0,53=0,99\end{array}$} \\
\hline & \multicolumn{4}{|c|}{$\begin{array}{c}\text { Soma dos edemas dos extratos } \\
0,66+0,93=1,59\end{array}$} & \multicolumn{4}{|c|}{ 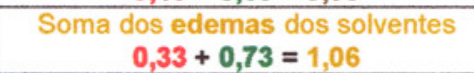 } \\
\hline & \multicolumn{4}{|c|}{$\begin{array}{l}\text { Soma dos edemas e eritemas dos } \\
\text { extratos } \\
\qquad \begin{array}{l}\mathbf{1 , 3 3}+\mathbf{1 , 5 9}=\mathbf{5}, 92\end{array}\end{array}$} & \multicolumn{4}{|c|}{$\begin{array}{l}\text { Soma dos edemas e eritemas dos } \\
\text { solventes } \\
\qquad 0,99+1,06=\mathbf{2}, \mathbf{0 5}\end{array}$} \\
\hline \multirow{2}{*}{\multicolumn{2}{|c|}{\begin{tabular}{c|} 
Subtração \\
Extrato - Solvente.
\end{tabular}}} & \multicolumn{7}{|c|}{ Contagem de Irritação Primária para C1 } \\
\hline & & \multicolumn{7}{|c|}{ CIP $=2,92-2,05=0,87$} \\
\hline
\end{tabular}

Tem-se então $\mathbf{C 1}=\mathbf{0 , 8 7} \mathrm{e}$, supondo outros quatro animais como exemplo $(C 2=1,03 ; C 3=0,95 ; C 3=1,25 ; C 3=0,83)$, pode-se obter $\circ$ Índice de Irritação Primária, somando-se as contagens dos animais e dividindo pelo número de animas. Portanto tem-se:

IIP $=(C 1+C 2+C 3+C 4+C 5): 5=4,93: 5=0,986$ 


\section{Anexo D}

\subsection{Planilhas de Anotações - Toxicidade Sistêmica}

Tabela 11.1 - Planilha para anotações dos dados obtidos no teste de toxicidade sistêmica.

\begin{tabular}{|c|c|c|c|c|c|c|}
\hline \multirow{2}{*}{$\begin{array}{l}\text { Meios } \\
\text { Animais }\end{array}$} & $\mathbf{E P}$ & $\mathbf{C P}$ & EI & CI & $\mathbf{E N}$ & $\mathbf{C N}$ \\
\hline & \multicolumn{6}{|c|}{ Peso em gramas (inicial e final) dos animais de teste } \\
\hline 1 & $\begin{array}{l}\text { Inicial: } \\
\text { Final: }\end{array}$ & $\begin{array}{l}\text { Inicial: } \\
\text { Final: }\end{array}$ & $\begin{array}{l}\text { Inicial: } \\
\text { Final: }\end{array}$ & $\begin{array}{l}\text { Inicial: } \\
\text { Final: }\end{array}$ & $\begin{array}{l}\text { Inicial: } \\
\text { Final: }\end{array}$ & $\begin{array}{l}\text { Inicial: } \\
\text { Final: }\end{array}$ \\
\hline 2 & $\begin{array}{l}\text { Inicial: } \\
\text { Final: }\end{array}$ & $\begin{array}{l}\text { Inicial: } \\
\text { Final: }\end{array}$ & $\begin{array}{l}\text { Inicial: } \\
\text { Final: }\end{array}$ & $\begin{array}{l}\text { Inicial: } \\
\text { Final: }\end{array}$ & $\begin{array}{l}\text { Inicial: } \\
\text { Final: }\end{array}$ & $\begin{array}{l}\text { Inicial: } \\
\text { Final: }\end{array}$ \\
\hline 3 & $\begin{array}{l}\text { Inicial: } \\
\text { Final: }\end{array}$ & $\begin{array}{l}\text { Inicial: } \\
\text { Final: }\end{array}$ & $\begin{array}{l}\text { Inicial: } \\
\text { Final: }\end{array}$ & $\begin{array}{l}\text { Inicial: } \\
\text { Final: }\end{array}$ & $\begin{array}{l}\text { Inicial: } \\
\text { Final: }\end{array}$ & $\begin{array}{l}\text { Inicial: } \\
\text { Final: }\end{array}$ \\
\hline 4 & $\begin{array}{l}\text { Inicial: } \\
\text { Final: }\end{array}$ & $\begin{array}{l}\text { Inicial: } \\
\text { Final: }\end{array}$ & $\begin{array}{l}\text { Inicial: } \\
\text { Final: }\end{array}$ & $\begin{array}{l}\text { Inicial: } \\
\text { Final: }\end{array}$ & $\begin{array}{l}\text { Inicial: } \\
\text { Final: }\end{array}$ & $\begin{array}{l}\text { Inicial: } \\
\text { Final: }\end{array}$ \\
\hline 5 & $\begin{array}{l}\text { Inicial: } \\
\text { Final: }\end{array}$ & $\begin{array}{l}\text { Inicial: } \\
\text { Final: }\end{array}$ & $\begin{array}{l}\text { Inicial: } \\
\text { Final: }\end{array}$ & $\begin{array}{l}\text { Inicial: } \\
\text { Final: }\end{array}$ & $\begin{array}{l}\text { Inicial: } \\
\text { Final: }\end{array}$ & $\begin{array}{l}\text { Inicial: } \\
\text { Final: }\end{array}$ \\
\hline
\end{tabular}

Tabela 11.2 - Planilha para anotações dos valores médios de peso corpóreo dos animais em gramas (g) e [índice de toxicidade sistêmica].

\begin{tabular}{c|cc|cc|cc}
\hline $\begin{array}{c}\text { Intervalo de } \\
\text { observações }\end{array}$ & EP & CP & EI & CI & EN & CN \\
\hline $\mathbf{0 h}$ & $00,00 \mathrm{~g}$ & $00,00 \mathrm{~g}$ & $00,00 \mathrm{~g}$ & $00,00 \mathrm{~g}$ & $00,00 \mathrm{~g}$ & $00,00 \mathrm{~g}$ \\
& {$[0]$} & {$[0]$} & {$[0]$} & {$[0]$} & {$[0]$} & {$[0]$} \\
\hline $\mathbf{2 4 h}$ & $00,00 \mathrm{~g}$ & $00,00 \mathrm{~g}$ & $00,00 \mathrm{~g}$ & $00,00 \mathrm{~g}$ & $00,00 \mathrm{~g}$ & $00,00 \mathrm{~g}$ \\
& {$[0]$} & {$[0]$} & {$[0]$} & {$[0]$} & {$[0]$} & {$[0]$} \\
\hline $\mathbf{4 8 h}$ & $00,00 \mathrm{~g}$ & $00,00 \mathrm{~g}$ & $00,00 \mathrm{~g}$ & $00,00 \mathrm{~g}$ & $00,00 \mathrm{~g}$ & $00,00 \mathrm{~g}$ \\
& {$[0]$} & {$[0]$} & {$[0]$} & {$[0]$} & {$[0]$} & {$[0]$} \\
\hline $\mathbf{7 2 h}$ & $00,00 \mathrm{~g}$ & $00,00 \mathrm{~g}$ & $00,00 \mathrm{~g}$ & $00,00 \mathrm{~g}$ & $00,00 \mathrm{~g}$ & $00,00 \mathrm{~g}$ \\
& {$[0]$} & {$[0]$} & {$[0]$} & {$[0]$} & {$[0]$} & {$[0]$} \\
\hline
\end{tabular}




\section{Anexo E}

\subsection{Planilha de acompanhamento dos coelhos}

Tabela 12.1 - Exemplo de quadro do acompanhamento da situação de cada coelho

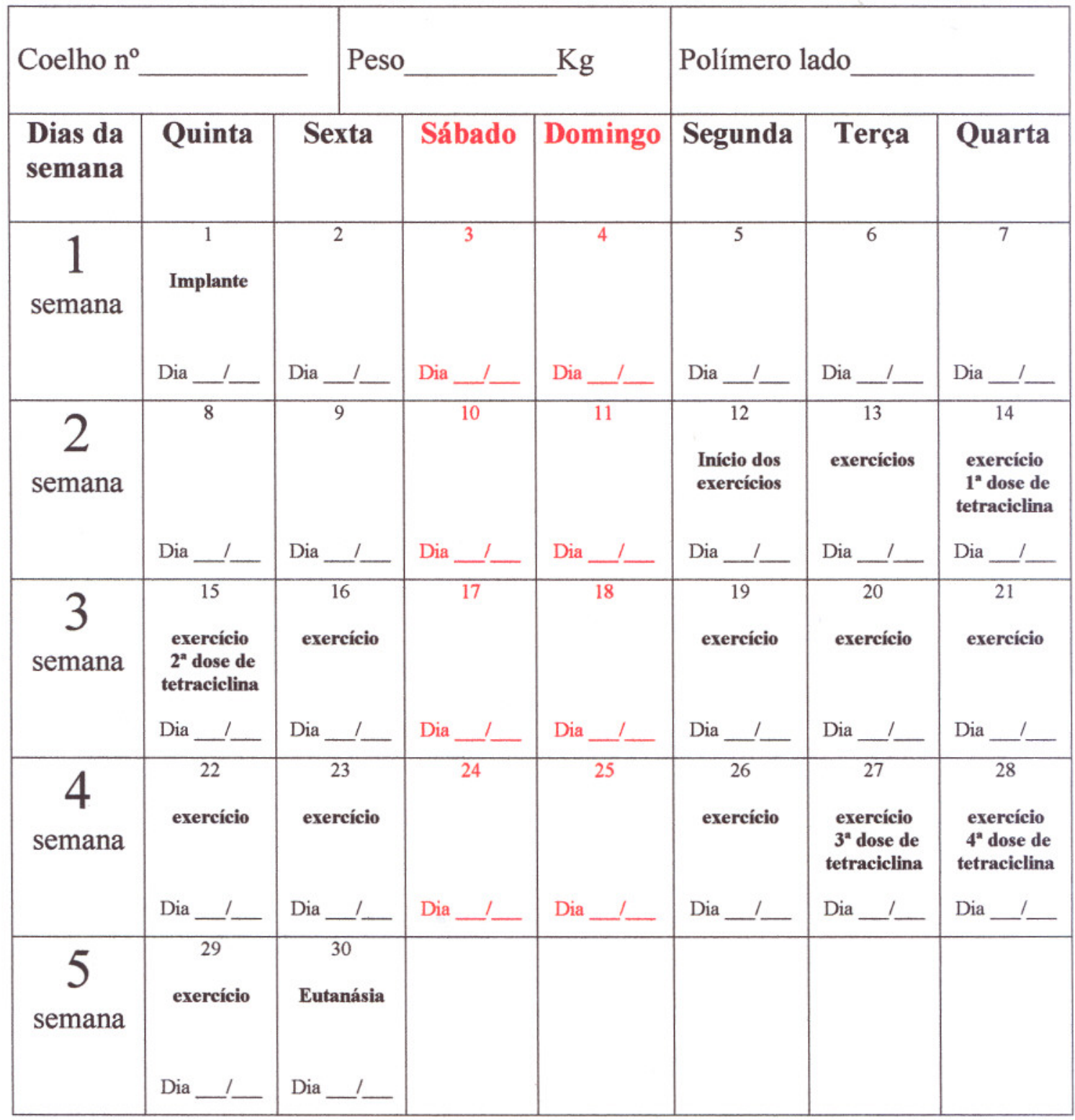

Dose de Quetamina ,$(0,5 \mathrm{ml} / \mathrm{kg})$

Exercício Físico $(\mathrm{s} / \mathrm{n})$

Dose de Xilazina ,$(0,4 \mathrm{ml} / \mathrm{kg})$

Dose de Tetraciclina , $(0,1 \mathrm{ml} / \mathrm{kg})$

Dose de Cefazolina Sódica . $(0,22 \mathrm{ml} / \mathrm{kg})$

OBS. 


\section{Anexo F}

\subsection{Adaptação de esteira ergométrica para os exercícios físicos dos coelhos}

A adaptação da esteira consistiu da substituição da polia de tração por uma de maior dimensão para reduzir a velocidade para aproximadamente $14 \mathrm{~m} / \mathrm{min}$. Esta nova polia foi confeccionada em poliéster pelo setor de Marcenaria do próprio Instituto de Ortopedia e Traumatologia do HC-FMUSP, conforme Figuras 13.1a e 13.1b.

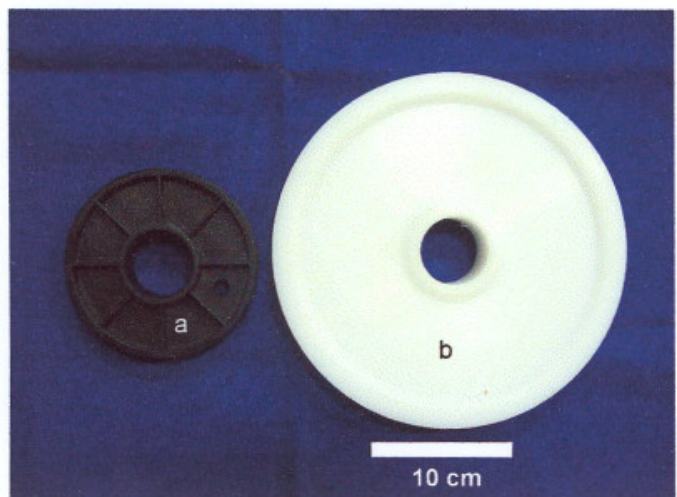

a)

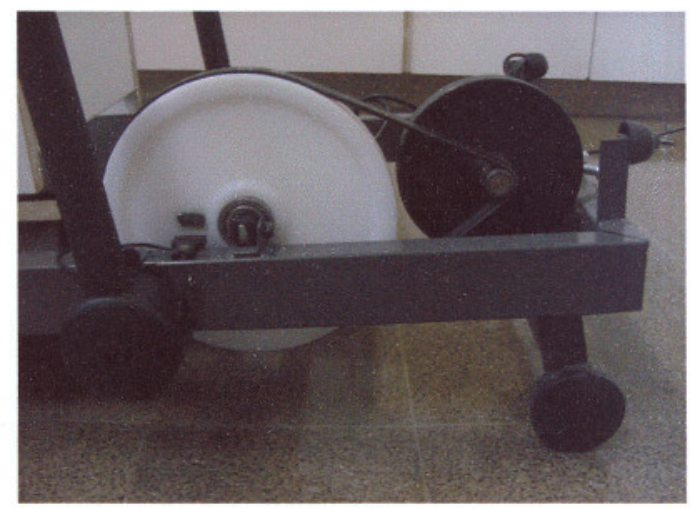

b)

Figura 13.1 - a) A polia "a" era a que estava anteriormente na esteira; a polia "b" é a atual. b) Polia redimensionada adaptada à esteira.

A contenção dos coelhos para os exercícios físicos foi conseguida através da adaptação de uma caixa de madeira revestida com fórmica (também confeccionada pelo Setor de Marcenaria do IOT) e parafusada ao suporte de madeira que dá sustentação à lona de caminhada. As Figuras 13.2a e 13.2b mostram a caixa de contenção com o coelho dentro dela.

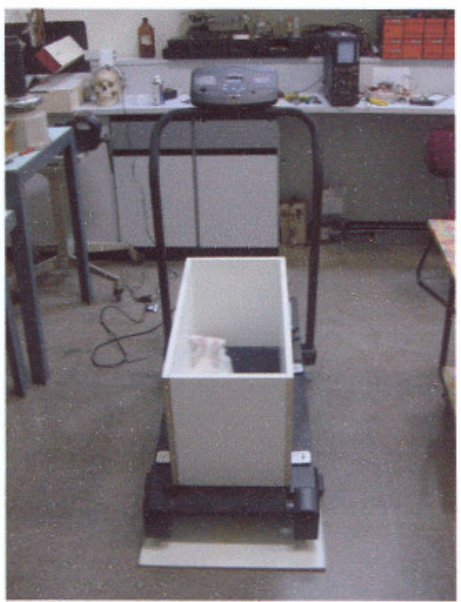

a)

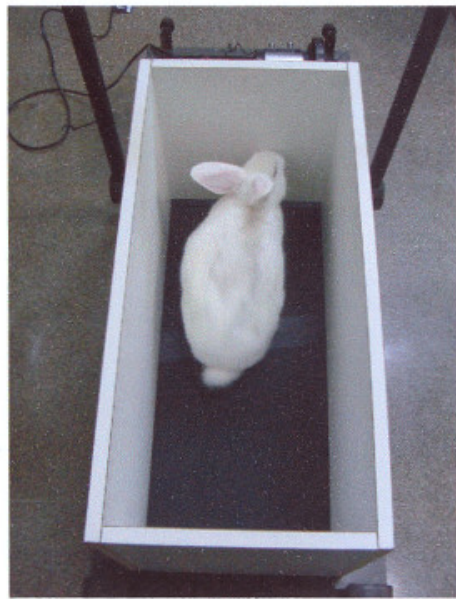

b)

Figura 13.2 - a) Esteira ergométrica adaptada para realização de exercício físico em coelhos implantados com PVDF. b) Coelho sendo exercitado. 


\section{Anexo $G$}

\subsection{Princípios Éticos na Experimentação Animal (Colégio Brasileiro de Experimentação Animal - COBEA)}

A pesquisa científica contribui com ponderável parcela para o bem estar do homem e dos animais.

Os conhecimentos de Biologia em geral, de saúde, de comportamento e das interações "homem-animal-ambiente" nem sempre podem ser obtidas só pela observação e pelo registro do que normalmente acontece, ao longo da vida, com o homem e com os animais, quer como indivíduo isolado quer como população e, por isto, a experimentação científica é absolutamente necessária para que o ciclo do conhecimento se complete, se renove e se torne útil.

Mas, para que o uso de animais com objetivos científicos seja moralmente aceitável e dê resultados confiáveis é fundamental ter-se a consciência que o animal como ser vivo, possui hábitos de vida próprios da sua espécie, tem memória, preserva o instinto de sobrevivência e é sensível à angústia e a dor, razão que preconizam posturas éticas em todos os momentos do desenvolvimento dos estudos com animais de experimentação.

Por isso, postula-se:

O progresso dos conhecimentos humanos, notadamente os referentes à Biologia, à Medicina Humana e dos animais, é necessário. $\mathbf{O}$ homem precisa utilizar animais na busca de conhecimento, para se nutrir, se vestir e trabalhar. Assim, ele deve respeitar o animal, seu auxiliar, como um ser vivente como ele. Postulado:

Artigo I - Todas as pessoas que pratiquem a experimentação biológica devem tomar consciência de que o animal é dotado de sensibilidade, de memória e que sofre sem poder escapar à dor;

Artigo II - O experimentador é, moralmente, responsável por suas escolhas e por seus atos na experimentação animal;

Artigo III - Procedimentos que envòlvam animais devem prever e se desenvolver considerando-se sua relevância para a saúde humana ou animal, a aquisição de conhecimento ou o bem da sociedade;

Artigo IV - Os animais selecionados para um experimento devem ser de espécie e qualidade apropriadas e apresentar boas condições de saúde, utilizando-se o número mínimo necessário para se obter resultados válidos. Ter em mente a utilização de métodos alternativos tais como modelos matemáticos, simulação por computador e sistemas biológicos "in vitro"; 
Artigo V - É imperativo que se utilizem os animais de maneira adequada, incluindo aí evitar o desconforto, angústia e dor. Os investigadores devem considerar que os processos determinantes de dor ou angústia em seres humanos causam o mesmo em outras espécies, a não ser que o contrário tenha se demonstrado;

Artigo VI - Todos os procedimentos com animais, que possam causar dor ou angústia, precisam se desenvolver com sedação, analgesia ou anestesia adequadas. Atos cirúrgicos ou outros atos dolorosos não podem se implementar em animais não anestesiados e que estejam apenas paralisados por agentes químicos e/ou físicos;

Artigo VII - Os animais que sofram dor ou angústia intensa ou crônica, que não possam se aliviar e os que não serão utilizados devem ser sacrificados por método indolor e que não cause estresse;

Artigo VIII - $\mathrm{O}$ uso de animais em procedimentos didáticos e experimentais pressupõe a disponibilidade de alojamento que proporcione condições de vida adequadas às espécies, contribuindo para sua saúde e conforto. $O$ transporte, a acomodação, a alimentação e os cuidados com os animais criados ou usados para fins biomédicos devem ser dispensados por técnico qualificado.

Artigo IX - Os investigadores e funcionários devem ter qualificação e experiência adequadas para exercer procedimentos em animais vivos. Deve-se criar condições para seu treinamento no trabalho, incluindo aspectos de trato e uso humanitário dos animais de laboratório. 


\section{Anexo $\mathcal{H}$}

\subsection{Etapas de dissecação, emblocamento em resina acrílica e confecção das lâminas para leitura histomorfométrica.}

Após a eutanásia dos animais, as tíbias são dissecadas como demonstrado na Figura 15.1. As placas foram retiradas e a tíbia foi cortada na região dos buracos dos parafusos de forma que a região onde feita a lesão para observação do crescimento ósseo ficasse centralizada. (Figura 15.2). A Figura 15.3 mostra o equipamento utilizado para o corte das amostras ósseas.

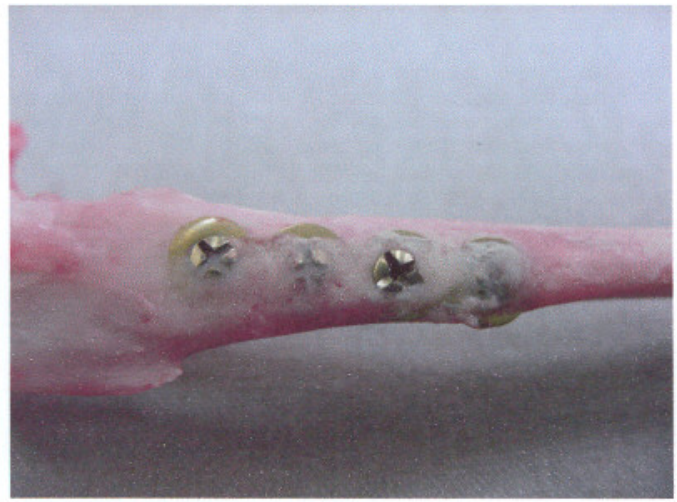

a)

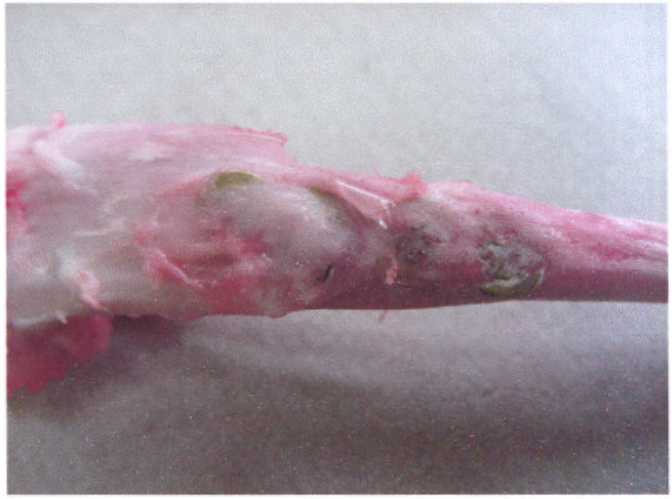

b)

Figura 15.1 - Tíbias de coelho implantadas: a) Tíbia direita sem PVDF, b) Tíbia esquerda com PVDF (note a diferença de crescimento do periósteo sobre a placa).

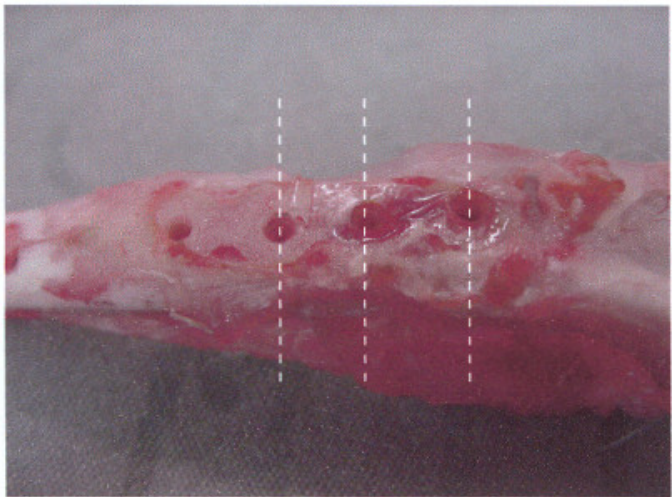

a)

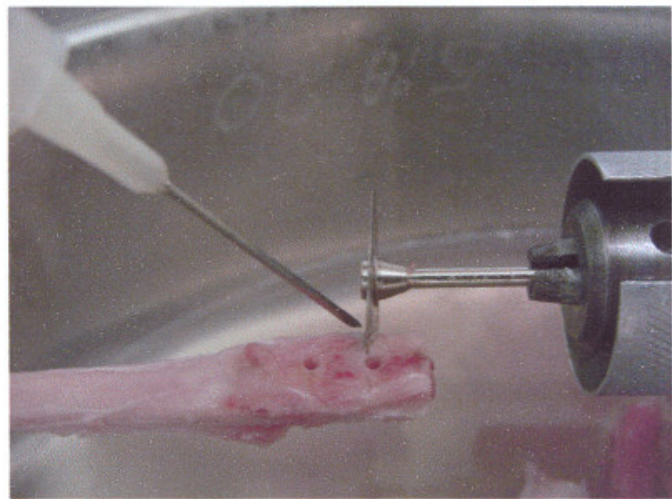

b)

Figura 15.2 - Tíbias de coelho dissecada: a) Tíbia já sem a placa e com as marcações imaginárias dos locais de corte; b) Tíbia sendo cortada com disco de aço para retirada da amostra de osso. A agulha no canto superior da figura é para refrigerar o locar de corte com soro fisiológico. 


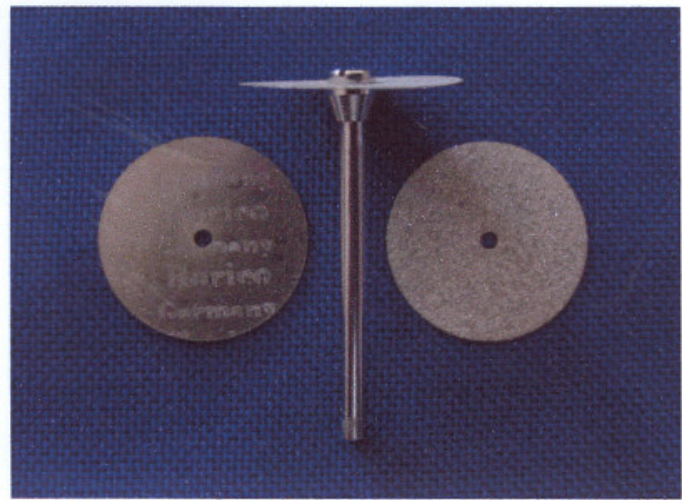

a)

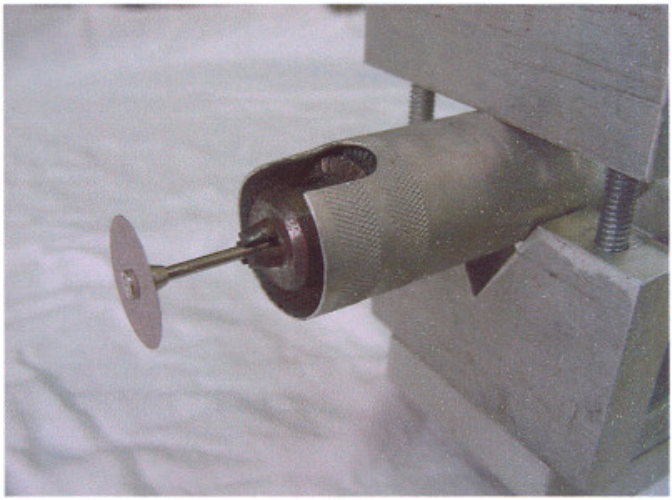

b)

Figura 15.3 - Equipamento utilizado para o corte das amostras ósseas: a) detalhe do disco de aço; b) Disco de aço acoplado a microretífica.

As amostras de ossos são então colocadas em etanol 70\% (a primeira etapa para a desidratação óssea para a confecção dos blocos). (Figura 15.4)

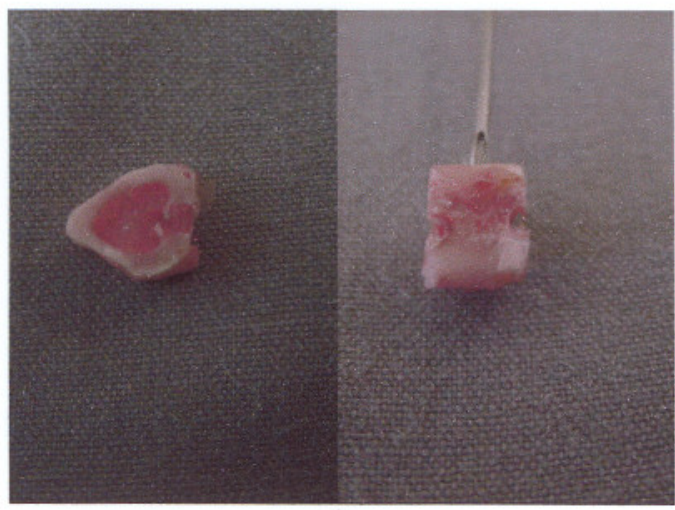

a)

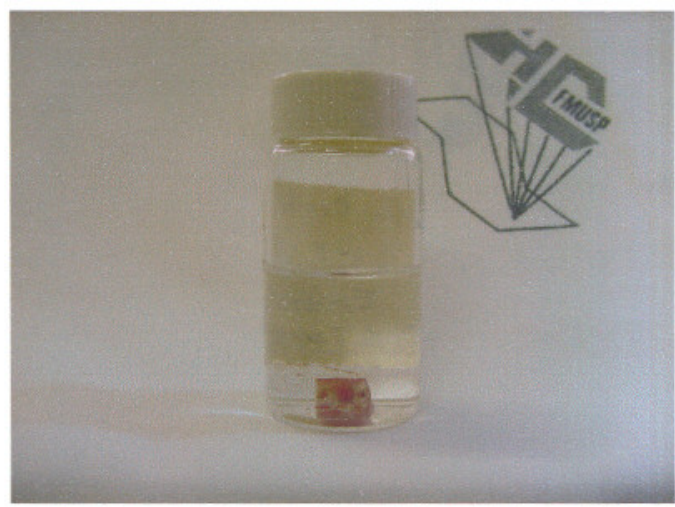

b)

Figura 15.4 - Peça a ser analisada retirada da tíbia, a) detalhe da peça; b) peça colocada em etanol $70 \%$ para 0 início do processo de desidratação.

\subsection{Inclusão das amostras teciduais ósseas calcificadas}

A amostra de tecido ósseo retirada da tíbia do coelho (entre o $2^{\circ}$ e $3^{\circ}$ furos), é então submetido a um protocolo muito usado para pesquisas histológicas onde se precisa analisar o osso mineralizado, como é o caso da histomorfometria óssea. Na primeira etapa, chamada fixação, a peça óssea fica imersa em etanol a 70\%(citado acima) por sete dias (com trocas diárias do álcool, ficando a temperatura ambiente). Na segunda etapa, que consiste na desidratação do tecido, a amostra fica imersa em etanol absoluto (100\%) por mais sete dias a temperatura ambiente (quanto mais desidratado, melhor será a penetração posterior pela resina). A seguir, a amostra é mergulhada em tolueno por 24 horas, também a temperatura ambiente. 
Após a máxima desidratação possível, segue-se a etapa de penetração pela resina, que consiste na imersão, seqüencial, em outras três soluções, aqui denominadas de Solução A, Solução l grama e Solução 2 gramas.

\section{- Solução A}

Consiste nos seguintes reagentes:

- $25 \%$ de Dibutilftalato (Merck $\mathrm{C}_{16} \mathrm{H}_{22} \mathrm{O}_{4}-\mathrm{n}^{0} 814157$ ) - (25 ml de Dibutilftalato);

- $75 \%$ de Metilmetacrilato - $\left(\mathrm{C}_{5} \mathrm{H}_{8} \mathrm{O}_{2}\right) 75 \mathrm{ml}$ de Metilmetacrilato) para $100 \mathrm{ml}$;

Nessa solução, a amostra fica por mais sete dias, em ambiente refrigerado.

\section{- Solução 1 grama}

- Consiste na Solução A, citada acima, com a adição de 1 grama de Peróxido de Benzoíla (Sigma $\left.\mathrm{C}_{14} \mathrm{H}_{10} \mathrm{O}_{4} \mathrm{~B} 2030\right)$

- A peça permanece nessa solução por mais sete dias também em ambiente refrigerado (geladeira)

\section{- Solução 2 gramas}

- Permanece a Solução A, porém agora com 2 gramas de Peróxido de Benzoíla.

- A amostra segue as mesmas condições da solução anterior (sete dias na geladeira)

Para a inclusão em resina, é feita uma "pré-base", ou seja, num frasco de $20 \mathrm{ml}$ com tampa, coloca-se cerca de $5 \mathrm{ml}$ de Solução 2 gramas, já polimerizada (esta solução pode ser polimerizada em estufa a $37^{\circ} \mathrm{C}$ ). $\mathrm{O}$ material é acondicionado sobre esta "pré-base" e, a seguir, completa-se com mais Solução 2 gramas. 0 bloco estará completamente endurecido em cerca de 48 horas na estufa a $37^{\circ} \mathrm{C}$. Esse frasco de $20 \mathrm{ml}$, onde foi feita a inclusão, serve somente como molde.

Após a polimerização completada, quebra-se o frasco de vidro e tem-se, portanto, a peça embutida (ou incluída) como pode ser observado na Figura 16.5a. A seguir, corta-se a resina com o auxílio de uma serra (Figura 15.5b) e lixa-se a peça até se conseguir um bloco retangular (Figura 15.6a), que recebe uma identificação. 


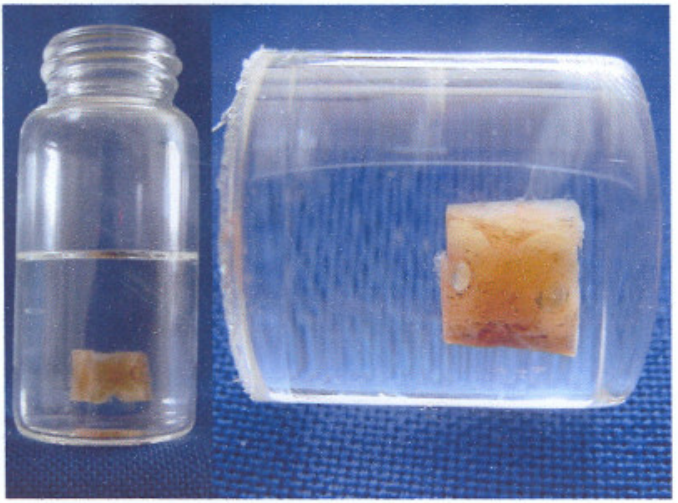

a)

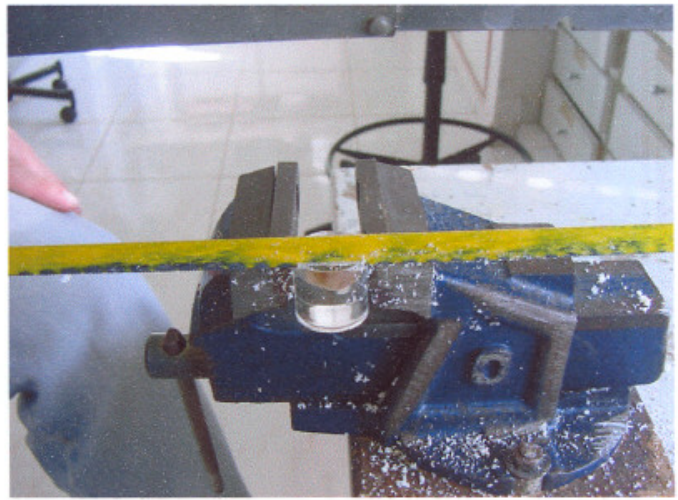

b)

Figura 15.5 - Montagem de um bloco histológico para corte em micrótomo. a) peça histológica embutida em resina dentro e fora do molde de vidro, b) acabamento para a confecção do bloco.

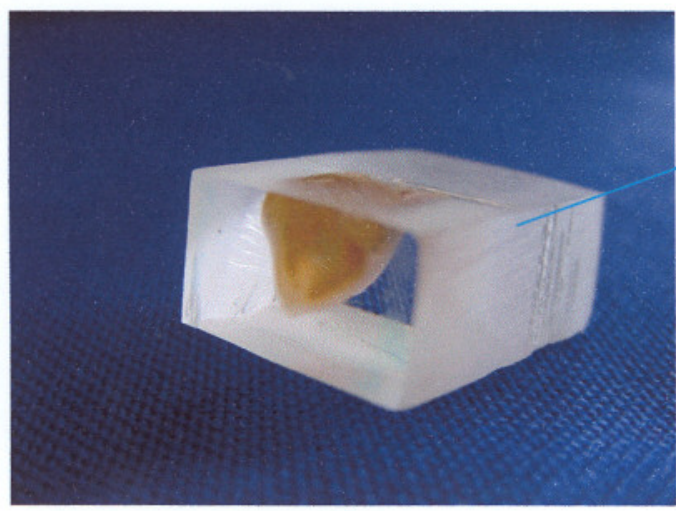

a)

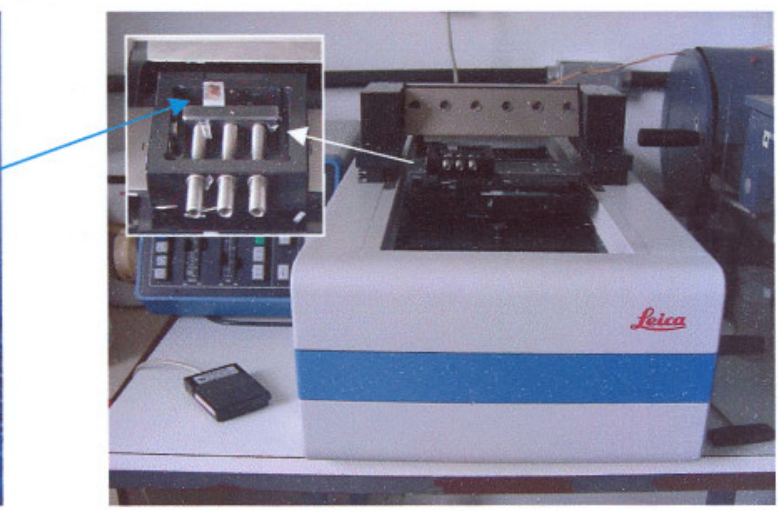

b)

Figura 15.6 - Montagem de um bloco histológico para corte em micrótomo. a) Formato do bloco para ser colocado nos equipamentos de corte histológico, b) Micrótomo Leica, com detalhe o bloco . (aparelho do Laboratório de Fisiopatologia Renal - LIM 16 - FMUSP).

Neste momento o bloco está pronto para a microtomia. O micrótomo utilizado (micrótomo de impacto com navalha de tungstênio modelo JUNG Policut S, Leica) (Figura $15.6 \mathrm{~b}$ ) é capaz de realizar cortes de até $5 \mu \mathrm{m}$ (para coloração) e cortes com $10 \mu \mathrm{m}$ (para fluorescência e subseqüente observação da dinâmica da mineralização óssea).

Os cortes são colocados em lâminas gelatinadas e estirados com álcool 50\% e 100\%.

A solução gelatinosa (gelatina $2 \%$ ), que recobre a lâmina é feita de gelatina branca em folha dissolvida ( \pm 2 gramas), em $100 \mathrm{ml}$ de água destilada, que é colocada sobre placa aquecedora e posteriormente ser estocada em geladeira. As lâminas são mergulhadas e retiradas uma a uma na gelatina, após estas terem sido limpas em solução sulfocrômica, lavadas com água corrente e em água destilada. Antes de se passar alguma lâmina na gelatina, estas devem ser mergulhadas em álcool e deixadas para secar.

Após a microtomia e o acondicionamento do material histológico sobre a lâmina, esta é deixa-se em estufa a $37^{\circ} \mathrm{C}$ por cerca de $12 \mathrm{hs}$. 
As lâminas prontas são então coradas para exame histológico (microscópio óptico comum) ou analisadas sem corante (microscópio óptico de fluorescência). Este último equipamento é o utilizado para a observação das marcações com tetraciclina. 


\section{Anexo I}

\subsection{Laudo histológico}

Dra. Maria Inês Onuchic Schultz
CRM - 40236 $\begin{gathered}\text { Dra. Elizete Lopes Guilherme } \\ \text { CRM - 42469 }\end{gathered}$

Dados: Experiência em coelhos. Implante de PVDF em osso tibial.

Qualidade do material: Foram recebidas 66 lâminas, numeradas de 1 a 34, contendo cortes histológicos tingidos pelo corante azul de toluidina.

Material encaminhado por: Departamento de Engenharia de Materiais, Aeronáutica e Automobilística. Aluno: André Luis Paschoal.

\section{LAUDO MICROSCÓPICO}

Os cortes histológicos são representados por tecido ósseo cortical e medular

Os cortes apresentam área mais ou menos circunscrita, orificial, com ossificaçäo.

$\mathrm{Na}$ quase totalidade dos cortes é possível delimitar área de ossificação.

Nas lâminas 18 e 19 não foi possivel delimitar e representar, respectivamente, a área de ossificação.

A neoformação óssea é caracterizada por trabéculas ósseas dispostas em várias direções e interligadas entre si.

As trabéculas são revestidas por fileiras de osteoblastos depositados sobre faixa de substância osteóide, que por sua vez está apoiada sobre lamínulas ósseas já mineralizadas.

Entre as trabéculas há tecido mesenquimal frouxo, vascularizado, com maior ou menor quantidade de tecido hematopoiético.

Em alguns fragmentos com ossificação mais adiantada observa-se atividade osteoclástica complementando a modelagem e remodelagem óssea.

Cada lâmina foi examinada com o intuito de comparar e dimensionar o grau de ossificação, objetivando encontrar diferenças entre os ossos tibiais que receberam polímero e foram submetidos ou não ao exercicio físico.

Para isso foi comparado o número de trabéculas ósseas em relação ao tecido mesenquimal interveniente. Cada lâmina recebeu uma graduação de $(+)$ a $(++++)$ para dimensionar a formação de trabéculas ósseas.

Dessa análise foi possivel observar que os ossos que receberam polimero e não foram submetidos ao exercício apresentaram maior número de trabéculas ósseas, com conseqüente maior obturação do orificio e portanto, maior ossificaçảo. Em seguida a estes animais vieram aqueles que também obtiveram as placas de polimero e foram submetidos aos exercícios; demonstrando portanto, no experimento, que a presença de polimero, de alguma forma, estimula a neo-formaçăo óssea.

Nas lâminas 27, 28, 29 e 30 há escassa neoformação óssea. Há poucas trabéculas na periferia do orificio e predomínio de tecidos adiposo e hematopoiético no centro. O tecido adiposo apresenta focos de necrose com reabsorção por histiócitos xantomatosos como se costuma observar em áreas de fratura.

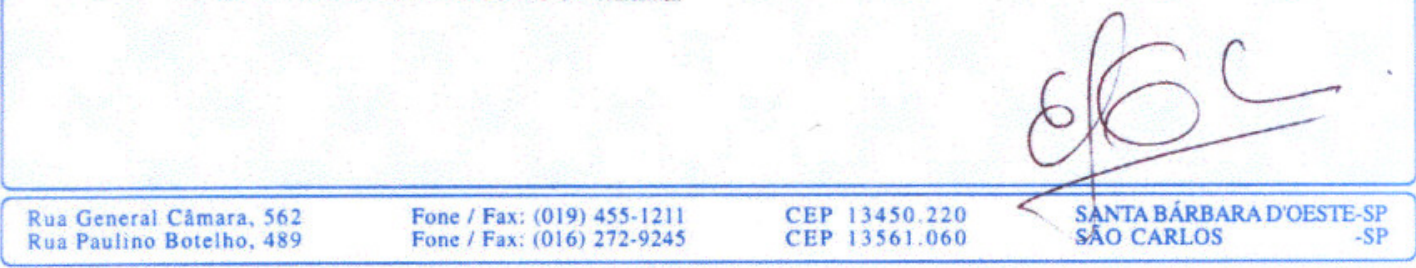




\section{Referências Bibliográficas}

1 - BRONZINO, J. D.; The biomedical enginnering - handbook, 2.ed., Flórida, Ed. CRC Press, Springer \& IEEE Press; 2000.

2 - DUCHEYNE,P. \& HASTINGS, G.W. , Funtional Behavior of orthopedic biomaterials, Florida, Ed. CRC Press, 1984, v.1; p. 3.

3 - PARK, J. B., Polymeric implant materials. Biomaterials science and engineering, Ed.Plenum, Iowa, 1984, p.265-303.

4 - FUKADA, E., Piezoelectric Properties of Biological Polymers. Quaterly Reviews of Biophysics, v.16(1), p. 59-87, 1983.

5 - DE ROSSI, D. E.; GALlETTI, P. M.; DARIO, P.; RICHARDSON, P. D.; . The electromechanical connection: piezoelectric polymers in artificial organs. In: GALLETTI, P. M.; DE ROSSI, D. E.; DE REGGI, A. S.; Medical applications of Piezoelectric polymers, Amsterdam, Ed. Gordon and Breach Science Publishers, 1988 , v.5, p.65-81.

6 - PANTELIS, P.; Piezoelectric polymers, Shell Polymers, v.8, n.3. p.78-81, 1984.

7 - (2002) - LEE, R. J.; HOPKINS, V.; As propriedades elétricas dos ossos.

http://planeta.terra.com.br/saude/novatrh/osteo.html. (comentário de tradutor). (01/Out).

8 - FERREN, R.A.; Synthesis of poly(vinylidene fluoride) and its copolymers. In: WANG, T.T., HERBERT, J.M., GLASS, A.M. The Aplications of Ferroeletric Polymers, Ed. Blackie and Son Ltd, Glasgow and London, 1988, p. 6-19.

9 -. GLASS, A.M.; Introduction. In: WANG, T.T., HERBERT, J.M., GLASS, A.M. The Aplications of Ferroeletric Polymers, Ed. Blackie and Son Ltd, Glasgow and London, 1988 , p. 1-5.

10 - HILCZER, B. \& MALACHY, J., Studies in electral and electronic Egineering electrets, ed.Elsevier, p343-366.

11 - LOVINGER, A.J. Poly(vinylidene fluoride), IN: BASSET, D.C. Developments in Crystalline Polymers, ed.Applied Science Publishers, p. 195-273, London, 1982.

12 - WANG, T.T., HERBERT, J.M., GLASS, A.M. The Aplications of Ferroeletric Polymers, Ed. Blackie and Son Ltd, Glasgow and London, 1988, 386p.

13 - (2000) - Poly(vinylidene fluoride. http://www.psrc.usm.edu/macrog/pvdf.htm. (18/Ago). 
14 - BROADHURST, M.G.; AND DAVIS, G.T. Physical basis for piezoelectricity in PVDF. In: GALlETTI, P. M.; DE ROSSI, D. E.; DE REGGI, A. S.; Medical applications of Piezoelectric polymers, Amsterdam, Ed. Gordon and Breeach Science Publishers, 1988, v.5, p.3-13.

15 - BIER, O. Esterilização e Desinfecção. In: Microbiologia e Imunologia. 24 ed. São Paulo: Melhoramentos, 1985. Cap.8, p. 149-170.

16 - DE ROSSI, D; Biomedical applications. In: WANG, T. T.; HERBERT, J. M.; GLASS, A. M.; The applications of ferroelectrical polymers. Glasgow and London, Ed. Blackie ans Son Ltd. 1988; Cap 9, p.209-220.

17 - CERIBELI, M. I. P. F. Raios gama e óxido de etileno I: Esterilizações incompatíveis? - análise crítica da literatura. Act Paulo. Enf., São Paulo, v - 10, n - 1, p. 86-92, 1997. Disponível em: http//www.hospvirt.org.br/enfermagem/port/artigos3/oxido de etileno.html. Acesso em 08 jun. 2000.

18 - Sterilization or Desinfection of Medical Devices: General Principles. HIP - Hospital Infections Program Disponive; em: http/www.cdc.gov/ncidod/hip/sterile/sterilgp.html Acesso em 19 mai 2000.

19 - OHIGASHI, H.; Ultrasonic transducers in the megahertz range. In: WANG, T. T.; HERBERT, J. M.; GLASS, A. M.; The aplications of ferroelectrical polymers. Glasgow and London, Ed. Blackie ans Son Ltd. 1988; Cap 11, p.237-273

20 - SCHLABERG, H. I.; DUFFY, J. S.; Piezoelectric polymer composite arrays for ultrasonic medical imaging applications. Sensors and Actuators A-Physical, 44:(2), p. 111-117, 1994.

21 - BOUAZIZ, A., RICHERT, A., CAPRANI, A., Vascular endothelial cell responses to different electrical charged poly(vinylidene fluoride) supports under static and oscillating flow conditions. Biomaterials, 18, p. 107-112, 1997.

22 - VALENTINI, R. F., VARGO, T.G.; GARDELLA, J.A.; AEBISCHER, P.; Electrically charged polymeric substrates enhance nerve-fiber outgrowth invitro. Biomaterials, 13(3), p.183-190, 1992.

23 - GUENAD, V.; VALENTINI, R. F., AEBISCHER, P.; Influence of surface texture of polymeric sheets on peripheral-nerve regeneration in a 2-compartment guidance-system. Biomaterials, 12(2), p.259-263, 1991.

24 - KLINGE, U.; KLOSTERHALFEN, B.;ÖTTINGER, A. P.; JUNGE, K.; SCHUMPELICK, V.; PVDF as a new polymer for the construction of surgical meshes. Biomaterials. 23, p.3487-3493, 2002. 
25 - FICAT, J. J.; THIECHERT, M.; FICAT, P.; LACABANNE.; MICHERON, F.; BAB; I.;

Piezoelectric induction of bone formation: Ultrastructural observations. In: GALLETTI, P. M.; DE ROSSI, D. E.; DE REGGI, A. S.; Medical applications of Piezoelectric polymers, Amsterdam, Ed. Gordon and Breach Science Publishers, 1988, v.5, p.265-268.

26 - SIKAVITSAS, V.I.; TEMENOFF, J. S.; MIKOS, A. G.; Biomaterials and bone mechanotransdiction; Biomaterials; v.22 p. 2581-2593, 2001.

27 - JUNQUEIRA, L. C.; CARNEIRO. J.;; Histologia Básica; 8.ed. Rio de Janeiro, Ed.

Guanabara Koogan S.A. 1995; Cap 8, p.108-26: Tecido ósseo

28 - (2001), Fisiología óssea - Matriz orgánica óssea.

http://www.efmuzambinho.org.br/prof/autran/apost/fis_ossea/fis_osso.htm

29 - ERIKSEN, E. F; AXELROD, D. W.; MELSEN, F. Bone Histomorphometry. New

York, Raven Press, p. 3 - 50. 1994.

30 - (2001), Informações para médicos - 3. Determinantes da massa óssea,

http://uddo.com/osteoporose/osteo2a.htm, (15/JUN).

31 - BOSKEY, A.L.; PASCHALIS, E.; Matrix proteins and biomineralization; In:

DAVIES, J. E.; Bone Engineering; ed. Rainbow Graphics and Printing Ltd; c.5; p.44-62;...Toronto, 2000.

32 - GIORDANO, V; GIORDANO, M; KNACKFUSS, I, G.; Fatores de crescimento e diferenciação ósseos. Efeitos sobre o processo de consolidação de fratura: presente e futuro. Rev. Bras. Medicina, v. 57, no 9, set/2000.

33 - BOUVIER, M.; The bioloby and composition of bone; In: COWIN, S. C.; Bone Mechanics; ed. CRC Press Ins.; Boca Raton; c. 1; p. 14; 2000.

34 - LENZA, H. R;; El sindrome osteoporotico. Sandoz. p. 13-25. 1986.

35 - YONEMURI, K; MATSANAGA, S. ISHIDOU, Y; MAEDA; S; YOSHIDA, H; Early effects of electrical stimulation on osteogenesis; Bone; $\quad$ v. 19; n.2; p. 173-180; aug/1996.

36 - CHEN, N. X.; RIDER, K. D.; PAVALKO; F. M.; TURNER, C.H.; BURR, D. B.; QIU, J.; DUNCAN, R. L.; $\quad \mathrm{Ca}^{2+}$ regulates fluid shear-induced cytoskeletal reorganization and gene expression in osteoblasts. Am. J. Physiol. Cell. Physiol.; 278: C989-C997, 2000

37 - KNETS, I. V. Adaptation and remodeling of articulate cartilage and bone tissue. In: HELMINIEN, H. J.; et.al; Joint Loading. Bristol, Wright, 1987, Cap. 10, p.251263.

38 - FUKADA, E; TAKAMATSU, T.; YASUDA, I.; Callus formation by electret; Japan. J. Appl. Phis. v. 14; n. 12; p. 2079-2780; 1975. 
39 - FUKADA, E.; Piezoelectric properties of biological polymers. Quaterly Reviews of Biophysics, 16.1, p.59-87, 1983.

40- DUARTE, L. R.; Method for healing bone fracture with ultrasound. Patente Industrial. US 4.530.360. 23 Julho 1985

41 - SILVA, J. S. P.; Avaliação histomorfométrica do efeito do ultra-som pulsado nas falhas ósseas provocadas em fềmures de rato: estudo experimental. São Paulo, 2001, 72p. Dissertação (Mestrado) - Faculdade de Medicina, Universidade de São Paulo.

42 - GJELSVIK, A.;...Bone Remodeling and Piezoelectricity - I. Journal of Biomechanics. V. 6, p.69-77, 1973.

43 - SILVA, C. C.; LIMA, C.G.A.; PINHEIRO, A. G.; GÓES, J. C. FIGUEIRÓ, S. D.; SOMBRA, A. S. B. On the piezoelectricity of collagen-chitosan films. Phys.Chem. Chem. Phys., 3. p.4154-4157. 2001.

44 - SILVA, C. C.; TOMAZINI. D.; PINHEIRO, A. G.; A. G.; ARANHA, N.; FIGUEIRÓ, S. D.; GÓES, J. C.; SOMBRA, A. S. B. Collagen-hidroxyapatite films: piezoelectric properties. Materials Science and Engineering B ., B6. p.210-218. 2001.

45 - TANAKA, S. M.; A new mechanical stimulator for cultured bone cells using piezoelectric actuator. Journal of Biomechanics. 32. p. 427-430, 1999.

46 - DAVIES, J. E.; CAUSTON, B.; BOVELL, Y, DAVY, K.; STURT, C.S.; The migration of osteoblast over substrata of discrete surface charge. s.ed. 3p. 1986.

47 - JIANQING, F.; HUIPIN, Y.; XINGDONG, Z.; Promotion of osteogenesis by a piezoelectric biological ceramic. Biomaterials. 18, p. 1531-1534, 1997;

48 - WIESMANN, H. P.; HARTIG, M.; STRATMANN, U.; MEYER; U.; JOOS, U.; Electrical stimulation influences mineral formation of osteoblast-like cell in vitro. Biochimica et Biophysica Acta. 1538, p. 28-37, 2001.

49 - YONEMORI, K.; MATSUNAGA, S.; ISHIDOU, Y.; MAEDA, S.; YOSHIDA, H.; Early effects od electrical stimulation on osteogenesis

50 - WANG, T.T., HERBERT, J.M., GLASS, A.M. The Applications of Ferroeletric Polymers, ed Blackie and Son Ltd, p. 1-66; 209-220,...Glasgow and London, 1988.

51 - WANG, T.T.; SEGGERN, H. von. High Electric Field Poling of Electroded Poly(Vinylidene Fluoride) at Room Temperature. Appl. Phys., v. 54(8), p. 4602-04, 1983.

52 - WILLIAMS, W.S. Piezoelectric Effects in Biological Materials. Ferroelectrics, v. 41, p. 225-246, 1982.

53 - GJELSVIK, A.;...Bone Remodeling and Piezoelectricity - II. Journal of Biomechanics. V. 6, p.187-193 1973. 
54 - (2001), RUSSO, L. A. T.; Métodos diagnósticos na osteoporose - histomorfometria. http://www.vicnet.com.br/starfire/sobrac/artigos/DIAGNOSTICOSOST.html, (15/JUN)

55 - FARIA. JR, L. J.; Diferentes métodos para análise crítica da osteointegração de implantes de titânio em tíbias de coelho. São Paulo, 2001. 314p. Tese (Doutorado) Instituto de Ciências Biomédicas da Universidade de São Paulo.

56 - LUGERO, G. G.; et.al. Histomorfometric evaluation of titanium implants in osteoporotic rabbits. Impl.Dent. v. 9, $\mathrm{n}^{\circ} 4$, p.1-6, 2000.

57 - KÖNNIG JR, B.; et.al; A study of different calcification areas in newly formed bone 8 weeks after insertion of dental implants um rabbit tibias. Ann. Anat. v. 180, p. 471 $475,1998$.

58 - PARFIT, A. M.; DREZNER, M. K.; GLORIEUX, F. H.; KANIS, J. A.; MALLUCHE, H.; MEUNIER, P. J.; OTT, S. M. ; RECKER, R. R; Bone histomorfometry: standardization of nomenclature, symbols, and units. Journal of Bone and Mineral Research, v.2, n.6, p.595-610. 1987.

59 - MEUNIER, P. J.; Bone Histomorfometry. In: RIGGIS, L.; MELTON III, L. J.; Osteoporosis: etiology, diagnosis and management. Philadelphia, Ed. LippincottRaven, 1995, 2.ed., cap. 13. p.299-318.

60 - COMPSTON, J.; Bone histomorphometry. In: ARNET, T. R.; HENDERSON, B.; Methods in bone biology. London, Champman \& Hall Medial, 1998, cap. 7, p.177197.

61 - INTERNATIONAL ORGANIZATION FOR STANDARDIZATION (1995). ISO 10993-10. Tests for irritation and sensitization. Biological Evaluation of Medical Devices, Switzerland.

62 - INTERNATIONAL ORGANIZATION FOR STANDARDIZATION (1995). ISO 10993-12. Sample Preparation and Reference Materials, Biological Evaluation of Medical Devices, Switzerland.

63 - AMERICAN SOCIETY FOR TESTING AND MATERIALS (1992). ASTM F619/79 - Standard Practice for Extraction of Medical Plastics, In: Medical Devices. Annual book of ASTM Standards. Philadelphia. v.13.01, , p. $172-175$.

64 - Biological Tests, Pharmacopeia of the The United States of America XXIII, Rockville, part 2, p. 1697-1703, 1995.

65 - INTERNATIONAL ORGANIZATION FOR STANDARDIZATION (1992). ISO 10993-5. Tests for genotoxicity, carcinogenicity and reproductive toxicity. Biological Evaluation of Medical Devices, Switzerland.

66 - AMERICAN SOCIETY FOR TESTING AND MATERIALS (1992). ASTM F895/84 (reaprov.1990) - Standard Test Method for Agar Diffusion Cell Culture 
Screening for Cytotoxicity, In: Medical Devices. Anmual book of ASTM Standards. Philadelphia. v.13.01, , p. $306-309$.

67 - AMERICAN SOCIETY FOR TESTING AND MATERIALS (1992). ASTM F719/81 (reaprov.1992) - Standard Practice for Testing Biomaterials in Rabbis for Primary Skin Irritation, In: Medical Devices. Annual book of ASTM Standards. Philadelphia. v.13.01, , p. $238-239$.

68 - AMERICAN SOCIETY FOR TESTING AND MATERIALS (1992). ASTM F749/87 - Standard Practice for Evaluating Material Extracts by Intracutaneous Injection in the Rabbit, In: Medical Devices. Annual book of ASTM Standards. Philadelphia. v.13.01, , p. $261-262$.

69 - INTERNATIONAL ORGANIZATION FOR STANDARDIZATION ISO 10993-11. Tests for systemic toxicity. Biological Evaluation of Medical Devices, Switzerland.

70 - AMERICAN SOCIETY FOR TESTING AND MATERIALS (1992). ASTM F750/87 - Standard Practice for Evaluating Material Extracts by Systemic Injection in the Mouse, In: Medical Devices. Annual book of ASTM Standards. Philadelphia. v.13.01, p. $263-265$.

71 - INTERNATIONAL ORGANIZATION FOR STANDARDIZATION (1992). ISO 10993-1. Guidance on selection of tests. Biological Evaluation of Medical Devices, Switzerland.

72 - INTERNATIONAL ORGANIZATION FOR STANDARDIZATION (1992). ISO 10993-2. Animal welfare requirements. Biological Evaluation of Medical Devices, Switzerland.

73 - ADAMS, C. E; The laboratory rabbit, IN: The UFAW Handbook on care and management of laboratory animals, Logman Scientific \& Technical, $6^{\text {a }}$ ed, Cap. 26, p. $415-435,1986$.

74 - FANTONI, D. T.; CORTOPOSSI, S. R. G.; Técnicas anestésicas em animais de laboratório, IN: Manual para técnicas em Biotério, Comissão de Ensino COBEA, São Paulo, Winner Graf, 2. ed, Cap. 15, p. 157 - 164, 1996.

75- HARKNESS, J. E.; WARGNER, J. E.; Biologia e Clínica de Coelhos e Roedores, Roca, São Paulo, 3 ed. p. 12-19; $41-83,1993$.

76 - RIVERA, E.; Ética, bem estar e legislação, IN: Manual para técnicas em Biotério, Comissão de Ensino COBEA, São Paulo, Winner Graf, 2. ed, Cap. 2, p. $11-14$, 1996. 
77 - (2001), Princípios Éticos na Experimentação Animal (Colégio Brasileiro de Experimentação Animal - COBEA) http://www.fop.unicamp.br/ceea/etica_animal.htm, (28/FEV).

78 - SOUZA, N. L.; MERUSSE, J. L. B.; A utilização de animais de laboratório, IN: Manual para técnicas em Biotério, Comissão de Ensino COBEA, São Paulo, Winner Graf, 2. ed, Cap. 1, p. 3-10, 1996.

79 - SOUZA, N. L.; GUIMARÃES, H. B.; Transporte, IN: Manual para técnicas em Biotério, Comissão de Ensino COBEA, São Paulo, Winner Graf, 2. ed, Cap. 16, p. $165-170,1996$.

80 - SOUZA, N. L.; Eutanásia, IN: Manual para técnicas em Biotério, Comissão de Ensino COBEA, São Paulo, Winner Graf, 2. ed, Cap. 17, p. 171-177, 1996.

81 - MASSONE, F.; Anestesiologia Veterinária - Farmacologia e Técnicas, Ed. Guanabara-Koogan, São Paulo, 1986, 3 ed. Cap. 10, p. 97-102; $194-196$.

82 - ROSA-MATIELLO, S.M.G. Influência do exercício em esteira na citologia do líquido sinovial e histologia da cartilagem articular em joelhos de coelhos. Ribeirão Preto, 1999 222p. Tese (Doutorado) - , Faculdade de Medicina de Ribeirão Preto, Universidade de São Paulo.

83 - MARTIN, T. J.; DEMPSTER, D. W.; Bone structure and cellular activity. In: STEVENSON, J. C.; LINDSAY, R.; Osteoporosis. London, Champman \& Hall Medial, 1998, Cap. 1, p.1-26. 


\subsection{Bibliografia consultada e não referenciada no texto}

- ALVES, N.; GIACOMETTI, J.A; OLIVEIRA Jr., O.N. Measuring Hysteresis Loops of Ferroelectric Polymer Using the Constant Charging Current Corona Triode. Rev, Sci. Instrumen, v. 62(7), p. 1840-43, 1991.

- ALVES, N.; MINAMI, G.; GIACOMETTI, J.A.; FERREIRA, G.F.L.; OLIVEIRA Jr., O.N. Surface Potentials of Corona-Charged Ferroelectric P(VDF-TFFE) Copolymer Samples. Ferroelectrics, v. 150, p. .219-26, 1993.

- BAER, S. \& LANG, S., Pyroelectric Polimer Electrets, IEEE Transactions on Dielectrics and Electral Insulution., v. 3, p. 647, 1996.

- BAUER, F. PVF2 Polymer. Ferroelectric Polarization and Piezoelectric Properties Under Dynamic Pressure and Shock. Wave Action. Ferroelectrics, v. 49, p. $231-40,1983$.

- BERGMAN, J.G.; Jr. McFEE, J.H.; CRANE, G.R. Pyroeletricity and Second Harmonic Generation in Polivinylidene Fluoride Films. Appl. Phys. Let, vol. 18(5), p. 203-05, 1971

- BREGER, L.; FURUKAWA, T. \& FUKADA, E. Bending Piezoelectricity in Polyvinylidene Fluoride. Japan. J. Apph Phys, v.15(1I), p. 2239-40, 1976.

- BROADHURST, M G. \& DAVIS, G. T. Topics in Appl., Electrets",Ed. G.M.Sessler, Springer - Veriag, Berlin , 1980, 285p.

- BROADHURST, M G., DAVIS, G. T. \& McKINNEY, J. B., Piezoelectricity and Pyroelectricity in Polyvinylidene Fluoride - A Model, J. Appl. Phys, v. 49, p. 4992, 1978.

- BROADHURST, M.G.; AND DAVIS, G.T. Ferroelectries Polarization in Polymer. Ferreelectries. v. 32, p. 177-80, 1981.

- BROADHURST, MG.; DAVIS, G.T.; McKINNEY, J.E.; COLLINS, RE. Piezoeletricity and Piryroeletricity Polyvinylidene Fluoride A Model. J. Appl. Phys., v. 49(10), p. 4992-97, 1978.

- BURKARD, H. \& PISTER, G., Reversible pyroelectricity and inverse Piezoelectricity in Polyvinylidene Fluoride, J. Appl. Phys., v. 45, p. 3360,1974

- CALLISTER, W.D. Materials Science and Engineering-AnIntroduction; 3a ed p. 445;633, 1994

- COSTA, MM. Estudo do Comportamento Elétrico de Filmes de PVDF na Fase $\alpha$. Instituto de Física de São Carlos. São Carlos, 1991 . (Dissertação).

- COSTA, M.M; GIACOMETTI, J.A. Electric field induced phase changes in polyvinylidene fluoride: effects from corona polarity and moisture. Appl. Phys. Lett, v. 62(10), p. 1091-93, 1993.

- DAS-GUPTA, D. K. Pyroelectricity in polymers. Ferroelectrics, v. 118, p. 165-89, 1991.

- DAS-GUPTA, D. K. \& DUFFY, J. S, Pyroelectricity in Polyvinylidene Fluoride, J.Appl. Phys., v. 50, p. $561,1979$.

- DAVIS, G. T., McKINNEY, Broadhurst, M. G. and Roth,Se. Electric field induced phase changes in poly(vinylidene fluoride), J. Appl. Phys., v. 49, p. 4998-5002, 1978.

- DIAS, C., SIMON, R., QUAD, R., \& DAS-GUPTA, D. K., Measurement of the pyroelectric Coefficient in Composites Using a Temperature Modulated Excitaction. J. Appl. Phys., v. 26, p. 106, 1993.

- DIAS, C.J.; DAS-GUPTA, D.K. Hysteresis Measurements on Ferroelectric Composites. J. Appl. Phys, v. 74, p. 6317, 1993.

- DICKENS, B.; BALIZER, E.; DeREGGI, A.S.; ROTH, S.C. Hysteresis Measurements of Remanent Polarization and Coercive Field in Polymer. J. Appl. Phys, v. 72(9), p. 4258-64, 1992.

- Disponível em: http://202.186.20.69/PRODUCTS/SINAGAMA/why_choose.htm. Acesso em 12 jum 2000

- Eldon James Sterilization Stability Sterilization Stability of Resin Materials Unions and Medical Components - Disponfvel em: http://www.eldonjames.com/html/sterilize.html. Acesso em 12 jun 2000

- Electron Beam Technology. Sure Beam Corporation.

- http://www.scan titan.com/medical/ebeamtech.html. Acesso em: 10 jun.2000.

- ELIAS, H. G. A Introduction to Polymer Science, 1 ed, Ed. VCH Publishers, Inc., New York; Weinheim, Germain, 1997

- Ethylene Oxide (EtO) Sterilizers. Fact Sheets and Inflamations, may 1999. Disponível em: http://chppmWww.apgea.army.mil/hmwp/Factsheets/eto.html. Acesso em: 06 jun 2000

- FARIA, R.M; NOGUEIRA, J.S.; ALVES, N. Influence of Moisture in Step-Voltage Measurements of PVDF. J. Phys. D: Appl. Phys., v. 25, p. 1518,1992

- FREDERICK, I.M. \& BROADHURST, G.M., Molecular Dipole Electrets, J. Appl.Phys., v. 46, p. 4204, 1975.

- FURUKAWA, T. Ferroelectrics Properties of Vinilidene Fuoride Copolymers. Phase Transition, v. 18, p. 143-211, 1989.

- FURUKAWA, T; DATE, M; FUKADA, E. Hysteresis Phenomena in Polyvinylidene Flluoride Under High Electric Field. J. Appl. Phys., v. 51(2), p. 1135-41, 1980. (a)

- FURUKAWA, T.; DATE, M.; FUKADA, E.; TAJISU, Y.; CHIBA, A. Ferroelectric Behavior in the Copolymer of Vinylidenefluoride and Trifluorethylene. Jap. J. AppL. Phys., v. 19(2), p. L109-L112, 1980. (b)

- FURUKAWA, T; DATE, M; JONHSON, G.E. Polarization Reversal Associated with Rotation of Chain Molecules in $\beta$-Phase Polyvinylidene Fluoride. J. Appl. Phys, v. 54(3), p. 1540-46, 1983 
- FURUKAWA, T.; JOHNSON, G.E. Measurements of Ferroelectrics Switching Characteristics in Polyvinylidene Fluoride. Appl. Phys. Lett., v. 38(12), p. 1027-29, 1981.

- GALLETTI, P.M; De ROSSI, D.E.; De REGGI, A.S. Medical Applications of Piezoelectric Polymers, Gordon and Breach Science Publisher, v. 5, 1988.

- GARN, L. E. \& SHARP, E. J. Use of low-frequency sinusoidal temperature waves to separate pyroelectric currents from nonpyroelectric currents". Part Iand II, J. Appl. Phys., v. 53, p. 8974-87, 1984.

- GIACOMETTI, J.A.; CAMPOS, J.S.C. Constant Current Corona Triode with Grid Voltage Control. Application to Polymer Foil Charging. Rev. Sci. Instrumen., v. 61(3), p. 1143-50, 1990

- GIACOMETTI, J.A.; RIBEIRO, P.A; RAPOSO, M; MARAT-MENDES, J.N.; CAMPOS, J.S.C; DeREGGI, A.S. Study of Poling Behavior of Biaxially Stretched Poly(Vinylidene Fluoride) Films Using the Constant-Current Corona Triode. J. Appl. Phys. v. 78(9), p. 5597-5603, 1995

- GROSS, B.; GIACOMETTI, J.A.; FERREIRA, G.F.L.; OLIVEIRA Jr., O.N. Current Constant Corona Charging in PVF2. J. Appl. Phys., v. 56(5), p. 1487-91, 1984.

- HARTHEY. N. P., SQUERE, P. T. \& PUTLEY, E. H., A new method of measuring pyroelectric coefficients, J.Physics E: Sci. Inst, v. S. p. $789,1972$.

- HASTINGS, G.W., DUCHEYNE, P., Macromolecular Biomaterials, ed CRC Press Inc., Flórida, 1984.

- HAYASHI, K \& KUBO, U. Pyroelectricity and space charge in polyvinylidene fluoride. Jpn. J. Appl. Phys., v. 21(9), p. 1379-80, 1982.

- HICKS, C.; JONES, T.E. Frequency Dependence of Remanent Polarization and the Correlation of Piezoelectric Coeficient with Remanent Polarization in Polyvinylidene Fluoride. Ferroelectrics, v. 32, p.119-26, 1981.

- HURREL, D. J. Recent developments in sterilization technology. Medical Plastics and Biomaterial Magazine, sept. 1998.

- IKEDA, S.; KOBAYASHI, S.; WADA, Y. Analysis of the Effect of Electrical Condutance of Ferroelectric Polymer on D-E Hysteresis Curve Measured by the Sawyer-Tower Method. J. Polym. Sci.: Polym. Phys. Edition, v. 23, p. 1513-21, 1985.

- JMBO, M; KOBAYASHI, S.; HORINO, K.; IKEDA, S.; WADA, Y. Analysis of the Hysteresis Curve of Ferrelectric Polymer by a Phenomenological Relaxation Theory. J. Polym. Sci: Polym. Phys., v. 22, p. 2139-44, 1984.

- KAWAI, H. The Ferroeletricity of Poly(vinylidene Flouride). Jpn. J. Appl. Phys., v. 8, p. 975-76, 1969.

- KEPLER, R.G. \& ANDERSON, R. A., On The Origin of Pyroelectricity in Polyvinylidene fluoride, J. Appl. Phys., v. 49, p. 4918, 1978.

- LOVINGER, A. J. Ferroelectric polymers. Science 220, p. 1115, 1983.

- LOVINGER, A.J. Developments in Crystalline Polymers-1, D.C. Basset Ed., Apllied Science Publisher, Gordon, 1982.

- MALMONGE, L.F. Caracterização Estrutural e Elétrica do Poli(fluoreto de vinilideno) para Aplicą̧ão em Transcutores. Instituto de Física de São Carlos. São Carlos, 1989. (Dissertą̧ão)

- MANO, E.B., Introdução a Poltmeros, Ed. Edgard Blücher, São Paulo, 1985

- Medical Surveillance Guidelines for Ethylene Oxide (non-mandatory) - 1910.1047. OSHA Occupational Safety \& Healt Administration U.S. Departament or Labor. Disponivel em: http:/www.osha-sle.gov/OshStd_data/1910_1047_APP_C.htmI Acesso em: 06 jum 2000.

- MŨLLER, M E; ALLGOWER, M; SCHNEIDER, R; WILLENEGGER, H; Manual of internal fixation, Springer-Verlag-Berling Heidelberg New York, 3 ed, p. 1-23, 1991

- NAKAMURA, K.; WADA, Y. Piezoeletricity, Pyroeletricity, and the Electrostriction Constant of Poly(vinilidene Fluoride. J. Polym. Sel, A-2, v. 9, p. 161-73, 1971.

- PARK,J.B., Biomaterials Science and Engineering, ed.Plenum, p.265-303, Iowa, 1984

- PFISTER, G., ABKOWITZ, M \& CRYSTAL, R. G. Pyroelectricity in polyvinylidene fluoride. J. Appl. Phys., v. 44(5), p. 2064-71, 1973.

- Procedimento de Instal acão e Uso de Gás Óxjdo de Etileno e suas Misturas em Unidades de Esterilização. Projeto de Regulamento Téenico - Secretaria de Vigilância Sanitária do Ministério da Saúde - Secretaria de Segurança e Saúde no Trabalho do ministério da Saúde. Disponivel em: http//www.laconsult com/ministério/portaria 97121. html Acesso em: 07 jun .2000

- PURVIS, C. K., \& TAYLOR, P.L, Piezoelectricity and Pyroelectricity in Polyvinylidene Fluoride: Influence of The Lattice Struture, J. Appl. Phys., v. 54, p. 1021, 1983.

- ROLLIK, D.; BAUER, S. E GERHARD-MULTHAUPT, R. J. Appl. Phys., v. 85, p. 3282, 1999.

- SAWYER, C.B.; TOWER, C.H. Rocheile Salt as a Dielectric. Phys. Rev. v. 35, p. 269-373, 1930

- SEGGERN, H von; WANG, T.T. Polarization Behavior During High Field Poling of Poly(Fluoride Polyvinylidene). J. Appl, Phys., v. 56(9), p. 2448-52, 1984.

- SESSLER, G.M.; WEST, J.E. "Electrets", edited by G.M Sessler, Topics in Applied Physics, v. 33, (Spring, Berlin, 1987), p. 347-381.

- SILVA, J. S. P.; Avaliação histomorfométrica do efeito do ultra-som pulsado nas falhas ósseas provocadas em fêmures de rato: estudo experimental. São Paulo, 2001. 84p. Dissertação (Mestrado) - Faculdade de Medicina da Universidade de São Paulo. 
- SILVA, O. L.; Avaliação da Biocompatibilidade do Nitreto de Titânio Usado como Revestimento para Biomateriais Metálicos. São Carlos, 1999. 176p. Tese (Livre Docência) - Escola de Engenharia de São Carlos da Universidade de São Paulo.

- SOUTEGHATE, P.D. Room-Temperature Poling and Morpology Changes in Pyroelectric Polyvinylidene Fluoride. Appl. Phys. Lett., v. 28, p. $250,1976$.

- Standard Practice for Selecting Generic Biological Test Methods for Materials and Devices, Designation: F 748 - 91; ASTM American Society for Testing and Materials. Ed 13.01 - Medical Devices, p. 257-260, 1992.

- Standard Practice for Testing Guinea Pigs for Contact Allergens: Guinea Pig Moximization Test, Designation: F 720 - 81; ASTM American Society for Testing and Materials. Ed 13.01 - Medical Devices, p. 240-241, 1992.

- Sterilization Alternatives: Electron Beam Radiation. Disponivel em:

- http://www.sterigenics.com/med/stertech/electron.htm. Acesso em: 10 jun 2000.

- Sterilization Altematives: Gama Radiation. Disponivel em: http://www.sterigenics.com/med/stertech/main-gamma.htm. Acesso em: 10 jun 2000

- TAMURA, M; Ogasawara, K; ONO, N; HAgIWARA, S. Piezoeletricity in Uniaxially Poly(Vinylidene Fluoride). J. Appl. Phys., v. 45(9), p. 3768-71, 1974.

- Technology Talk Sterilization Disponfvel em:

- http:medical distribution. com/www/ttsteri.html. Acesso em 19 mai.2000

- Tests for local effects after implantation - Parte 6; International Organization for Standardization - ISO 10993 - Biological Evaluation of Medical Devices, 1992.

- TEYSSÈDRE, G., BERNÉS, A. \& LACABANNE, C., Temperature Dependence of The Pyroelectric Coefficient in Polyvinylidene Fluoride. Ferroelectrics, v. 160, p. 67, 1994.

- The Principles os Micro-Clean Sterilization Technology. Steamatic Disponivel em: http:// wwwsteamatic-cr.com/bioclean/MICROCLEAN.html. Acesso em: 19 mai 2000.

- VALLET-REGI, M., Introduction to World of Biomaterials, Departamento de química Inorgánica y Bioinorgánica, Facultad de Farmacia, Universida Complutense de Madrid Apostila.

- VAUGHAN, J. A; The European wild rabbit, IN: The UFAW Handbook on care and management of laboratory animals, Logman Scientific \& Technical, $\theta$ ed, Cap. 25, p. 411-414, 1986

- WADA, Y. \& HAYAKAWA, R. Piezoelectricity and Pyroelectricity of Polymers. Japan. J. Apph Phys, v. 15(11), p.2041-57, 1976.

- WADA, Y. \& HAYAKAWA, R, A Model Theory of Piezo- and Pyroelectricity of Poly(vinylidene fluoride) Electret. Ferroelectrics, v. 32,p. 115, 1981 .

- WISNIEWSKI, C. Caracterização de Polímeros Ferroelétricos: Metodologia e Resultados. IFSC-USP. São Carlos, 1999. 145p (Tese).

- WISNIEWSKI, C., GIACOMETTI, J. \& FERREIRA, G.F. L. Determinação da polarização ferroelétrica do PVDF usando o método de Rampa de Tensão. 5o Congresso Brasileiro de Polímeros. Águas de Lindóia, 1999.

- WISNIEWSKI, C., GIACOMETTI, J. A., MOURA, W. A. \& FERREIRA, G.F. L. Dependence of the PVDF Ferroelectric Polarization on the Electric Field Obtained by Two Methods. ISE 10, Grécia, 1999.

- (1999), Spherulite of Pohy(vinylidene fluoride), http:/www/chem.ut.edw/chem-dept/marand/PVDF2.gif

- (2001), A Funçăo de Paratireoide normal e anormal,

- http:// www.hpth.hpg.com.be/afuncaodaparatireiodenormaleanormal.htm, (08/SET) 


\section{Apêndice I}

\subsection{Tabelas com os dados observados de formação de edemas e eritemas no teste de Sensibilidade Intracutânea: Obtenção da Contagem de Irritação Primária.}

As Tabelas 18.1, 18.2, 18.3, 18.4 e 18.5 trazem os resultados obtidos com os testes de sensibilidade intracutânea realizados no dorso dos cinco coelhos marcados como A1, A2, A3, A4 e A5 respectivamente, que receberam inoculações com Extratos e Controles, conforme citado.

Tabela 18.1 - Planilha de resultados para Contagem de Irritação Primária. Coelho A1

\begin{tabular}{|c|c|c|c|c|c|c|c|c|}
\hline & Extrato & Polar & Extrato & Não-Polar & Solvente & Polar & Solvente & Não-Polar \\
\hline & Eritema & Edema & Eritema & Edema & Eritema & Edema & Eritema & Edema \\
\hline \multirow{5}{*}{24 Horas } & 0 & 0 & 0 & 1 & 1 & 0 & 0 & 1 \\
\hline & 0 & 0 & 0 & 1 & 0 & 0 & 0 & 1 \\
\hline & 0 & 0 & 0 & 1 & 0 & 0 & 0 & 1 \\
\hline & 0 & 0 & 0 & 1 & 0 & 0 & 0 & 1 \\
\hline & 0 & 0 & 0 & 1 & 0 & 0 & 0 & 1 \\
\hline \multirow{5}{*}{48 horas } & 0 & 0 & 0 & 0 & 0 & 0 & 0 & 0 \\
\hline & 0 & 0 & 0 & 0 & 0 & 0 & 0 & 0 \\
\hline & 0 & 0 & 0 & 0 & 0 & 0 & $\mathbf{0}$ & 0 \\
\hline & 0 & 0 & 0 & 0 & 0 & 0 & $\mathbf{0}$ & 0 \\
\hline & 0 & 0 & 0 & 0 & 0 & 0 & 0 & 0 \\
\hline \multirow{5}{*}{ 72horas } & 0 & 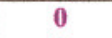 & $\mathbf{0}$ & 0 & 0 & 0 & 0 & 0 \\
\hline & 0 & 0 & 0 & 0 & 0 & 0 & 0 & 0 \\
\hline & $\mathbf{0}$ & 0 & 0 & 0 & 0 & 0 & 0 & 0 \\
\hline & 0 & 0 & 0 & 0 & 0 & 0 & 0 & 0 \\
\hline & 0 & 0 & 0 & 0 & 0 & 0 & 0 & 0 \\
\hline Total & 0 & 0 & 0 & 5 & 1 & 0 & 0 & 5 \\
\hline$\div$ pelo & $0: 15=$ & $0: 15=$ & $0: 15=$ & $5: 15=$ & $1: 15=$ & $0: 15=$ & $0: 15=$ & $5: 15=$ \\
\hline $\begin{array}{l}\text { Número de } \\
\text { observações }\end{array}$ & 0,00 & 0,00 & 0,00 & 0,34 & 0,07 & 0,00 & 0,00 & 0,34 \\
\hline \multirow{6}{*}{ Somas } & \multicolumn{4}{|c|}{ Soma dos eritemas dos extratos } & \multicolumn{4}{|c|}{ Soma dos eritemas dos solventes } \\
\hline & \multicolumn{4}{|c|}{$0,00+0,00=0,00$} & \multicolumn{4}{|c|}{$0,06+0,00=0,07$} \\
\hline & \multicolumn{4}{|c|}{ Soma dos edemas dos extratos } & \multicolumn{4}{|c|}{ Soma dos edemas dos solventes } \\
\hline & \multicolumn{4}{|c|}{$0,00+0,34=0,34$} & \multicolumn{4}{|c|}{$0,00+0,34=0,34$} \\
\hline & \multicolumn{4}{|c|}{ Soma dos edemas e eritemas dos extratos } & \multicolumn{4}{|c|}{ Soma dos edemas e eritemas dos solventes } \\
\hline & \multicolumn{4}{|c|}{$0,00+0,34=0,34$} & \multicolumn{4}{|c|}{$0,07+0,34=0,41$} \\
\hline \multicolumn{2}{|c|}{$\begin{array}{c}\text { Subtração } \\
\text { Extrato - Solvente. }\end{array}$} & \multicolumn{7}{|c|}{$\begin{array}{l}\text { Contagem de Irritação Primária para A1 } \\
\qquad \mathrm{CIP}=0,34-0,41=-0,07^{*}\end{array}$} \\
\hline
\end{tabular}

Normas Técnica indicam ser uma reação previsivel.) 
Tabela 18.2 - Planilha de resultados para Contagem de Irritação Primária. Coelho A2

\begin{tabular}{|c|c|c|c|c|c|c|c|c|}
\hline & Extrato & Polar & Extrato & Não-Polar & Solvente & Polar & Solvente & Não-Polar \\
\hline & Eritema & Edema & Eritema & Edema & Eritema & Edema & Eritema & Edema \\
\hline \multirow{5}{*}{24 Horas } & 1 & 0 & 0 & 0 & 0 & 0 & 0 & 0 \\
\hline & $\mathbf{1}$ & $\mathbf{0}$ & 0 & $\mathbf{0}$ & 0 & 0 & 0 & 0 \\
\hline & 0 & 0 & 0 & 0 & 0 & 0 & 0 & 0 \\
\hline & 0 & 0 & 0 & 0 & 0 & 0 & $\mathbf{0}$ & 0 \\
\hline & $\mathbf{0}$ & $\mathbf{0}$ & $\mathbf{0}$ & 0 & 0 & 0 & 0 & 0 \\
\hline \multirow{5}{*}{48 horas } & $\mathbf{0}$ & $\mathbf{0}$ & $\mathbf{0}$ & 0 & 0 & 0 & 0 & 0 \\
\hline & 0 & 0 & 0 & 0 & 0 & 0 & 0 & 0 \\
\hline & 0 & 0 & 0 & 0 & 0 & 0 & 0 & 0 \\
\hline & $\mathbf{0}$ & $\mathbf{0}$ & $\mathbf{0}$ & 0 & 0 & 0 & $\mathbf{0}$ & $\mathbf{0}$ \\
\hline & 0 & 0 & 0 & 0 & 0 & 0 & 0 & 0 \\
\hline \multirow{5}{*}{ 72horas } & 0 & 0 & 0 & 0 & 0 & 0 & 0 & 0 \\
\hline & 0 & 0 & 0 & 0 & 0 & 0 & 0 & 0 \\
\hline & 0 & 0 & 0 & 0 & 0 & 0 & 0 & 0 \\
\hline & 0 & 0 & 0 & 0 & $\mathbf{0}$ & $\mathbf{0}$ & $\mathbf{0}$ & $\mathbf{0}$ \\
\hline & $\mathbf{0}$ & $\mathbf{0}$ & $\mathbf{0}$ & $\mathbf{0}$ & 0 & $\mathbf{0}$ & $\mathbf{0}$ & $\mathbf{0}$ \\
\hline Total & 2 & $\mathbf{0}$ & $\mathbf{0}$ & $\mathbf{0}$ & 0 & 0 & 0 & $\mathbf{0}$ \\
\hline$\div$ pelo & $2: 15=$ & $0: 15=$ & $0: 15=$ & $0: 15=$ & $0: 15=$ & $0: 15=$ & $0: 15=$ & $0: 15=$ \\
\hline $\begin{array}{l}\text { Número de } \\
\text { observações }\end{array}$ & 0,14 & 0,00 & 0,00 & 0,00 & 0,00 & 0,00 & 0,00 & 0,00 \\
\hline \multirow{6}{*}{ Somas } & \multicolumn{4}{|c|}{ Soma dos eritemas dos extratos } & \multicolumn{4}{|c|}{ Soma dos eritemas dos solventes } \\
\hline & \multicolumn{4}{|c|}{$0,14+0,00=0,14$} & \multicolumn{4}{|c|}{$0,00+0,00=0,00$} \\
\hline & \multicolumn{4}{|c|}{ Soma dos edemas dos extratos } & \multicolumn{4}{|c|}{ Soma dos edemas dos solventes } \\
\hline & \multicolumn{4}{|c|}{$\begin{array}{c}\mathbf{0 , 0 0 + 0 , 0 0}=\mathbf{0 , 0 0} \\
\text { Soma dos edemas e eritemas dos extratos }\end{array}$} & \multicolumn{4}{|c|}{$\mathbf{0 , 0 0 + 0 , 0 0 = 0 , 0 0}$} \\
\hline & \multicolumn{4}{|c|}{ Soma dos edemas e eritemas dos extratos } & \multicolumn{4}{|c|}{ Soma dos edemas e eritemas dos solventes } \\
\hline & \multicolumn{4}{|c|}{$0,14+0,00=0,14$} & \multicolumn{4}{|c|}{$\mathbf{0 , 0 0 + 0 , 0 0 = \mathbf { 0 , 0 0 }}$} \\
\hline \multicolumn{2}{|c|}{$\begin{array}{c}\text { Subtração } \\
\text { Extrato - Solvente. }\end{array}$} & \multicolumn{7}{|c|}{$\begin{array}{l}\text { Contagem de Irritação Primária para A2 } \\
\qquad \mathrm{CIP}=0,14-0,00=0,14\end{array}$} \\
\hline
\end{tabular}

Tabela 18.3 - Planilha de resultados para Contagem de Irritação Primária. Coelho A3

\begin{tabular}{|c|c|c|c|c|c|c|c|c|}
\hline & Extrato & Polar & Extrato & Não-Polar & Solvente & Polar & Solvente & Não-Polar \\
\hline & Eritema & Edema & Eritema & Edema & Eritema & Edema & Eritema & Edema \\
\hline \multirow{5}{*}{24 Horas } & 0 & 0 & 0 & 0 & 0 & 0 & 0 & 0 \\
\hline & 0 & 0 & 0 & 0 & 0 & 0 & 0 & 0 \\
\hline & 1 & 0 & 0 & 0 & 0 & 0 & 0 & 0 \\
\hline & 0 & 0 & 0 & 0 & 0 & 0 & 0 & 0 \\
\hline & 0 & 0 & 0 & 0 & 0 & 0 & 0 & 0 \\
\hline \multirow{5}{*}{48 horas } & 0 & 0 & 0 & 0 & 0 & 0 & 0 & 0 \\
\hline & 0 & 0 & 0 & 0 & 0 & 0 & 0 & 0 \\
\hline & 0 & 0 & 0 & 0 & 0 & 0 & 0 & 0 \\
\hline & 0 & 0 & 0 & 0 & 0 & 0 & 0 & 0 \\
\hline & 0 & 0 & 0 & 0 & 0 & 0 & 0 & 0 \\
\hline \multirow{5}{*}{ 72horas } & 0 & 0 & 0 & 0 & 0 & 0 & 0 & 0 \\
\hline & $\mathbf{0}$ & 0 & 0 & 0 & $\mathbf{0}$ & 0 & 0 & 0 \\
\hline & 0 & $\mathbf{0}$ & 0 & 0 & 0 & 0 & 0 & 0 \\
\hline & $\mathbf{0}$ & $\mathbf{0}$ & 0 & 0 & 0 & 0 & 0 & 0 \\
\hline & 0 & 0 & 0 & 0 & 0 & 0 & 0 & 0 \\
\hline Total & 1 & 0 & 0 & 0 & 0 & 0 & 0 & 0 \\
\hline$\div$ pelo & $1: 15=$ & $0: 15=$ & $0: 15=$ & $0: 15=$ & $0: 15=$ & $0: 15=$ & $0: 15=$ & $0: 15=$ \\
\hline $\begin{array}{l}\text { Número de } \\
\text { observações }\end{array}$ & 0,07 & 0,00 & 0,00 & 0,00 & 0,00 & 0,00 & 0,00 & 0,00 \\
\hline \multirow{6}{*}{ Somas } & \multicolumn{4}{|c|}{ Soma dos eritemas dos extratos } & \multicolumn{4}{|c|}{ Soma dos eritemas dos solventes } \\
\hline & \multicolumn{4}{|c|}{$\begin{array}{c}0,07+0,00=0,07 \\
\text { Soma dos edemas dos extratos }\end{array}$} & \multicolumn{4}{|c|}{$0,00+0,00=0,00$} \\
\hline & \multirow{2}{*}{\multicolumn{4}{|c|}{$\begin{array}{c}\text { Soma dos edemas dos extratos } \\
0.00+0.00=0.00\end{array}$}} & \multicolumn{4}{|c|}{ Soma dos edemas dos solventes } \\
\hline & \multirow{2}{*}{\multicolumn{4}{|c|}{$\begin{array}{c}\mathbf{0 , 0 0 + 0 , 0 0}=\mathbf{0 , 0 0} \\
\text { Soma dos edemas e eritemas dos extratos }\end{array}$}} & \multicolumn{4}{|c|}{$0,00+0,00=0,00$} \\
\hline & & & & & \multicolumn{4}{|c|}{ Soma dos edemas e eritemas dos solventes } \\
\hline & \multicolumn{4}{|c|}{$\begin{array}{l}\text { Soma dos edemas e eritemas dos extratos } \\
\mathbf{0 , 0 7 + 0 , 0 0}=\mathbf{0 , 0 7}\end{array}$} & & $0,00+$ & $00=\mathbf{0 , 0 0}$ & \\
\hline \multicolumn{2}{|c|}{$\begin{array}{c}\text { Subtração } \\
\text { Extrato - Solvente. }\end{array}$} & \multicolumn{7}{|c|}{$\begin{array}{l}\text { Contagem de Irritação Primária para A3 } \\
\qquad \mathrm{CIP}=0,07-0,00=0,07\end{array}$} \\
\hline
\end{tabular}


Tabela 18.4 - Planilha de resultados para Contagem de Irritação Primária. Coelho A4

\begin{tabular}{|c|c|c|c|c|c|c|c|c|}
\hline & Extrato & Polar & Extrato & Não-Polar & Solvente & Polar & Solvente & Não-Polar \\
\hline & Eritema & Edema & Eritema & Edema & Eritema & Edema & Eritema & Edema \\
\hline \multirow{5}{*}{24 Horas } & 0 & 0 & 0 & 0 & 0 & 0 & 0 & 0 \\
\hline & $\mathbf{0}$ & $\mathbf{0}$ & $\mathbf{0}$ & $\mathbf{0}$ & $\mathbf{0}$ & $\mathbf{0}$ & $\mathbf{0}$ & $\mathbf{0}$ \\
\hline & $\mathbf{0}$ & $\mathbf{0}$ & 0 & $\mathbf{0}$ & $\mathbf{0}$ & $\mathbf{0}$ & $\mathbf{0}$ & $\mathbf{0}$ \\
\hline & 0 & $\mathbf{0}$ & 0 & 0 & $\mathbf{0}$ & 0 & 0 & 0 \\
\hline & 0 & 0 & 0 & $\mathbf{0}$ & 0 & 0 & 0 & 0 \\
\hline \multirow{5}{*}{48 horas } & $\mathbf{0}$ & $\mathbf{0}$ & 0 & $\mathbf{0}$ & 0 & 0 & 0 & 0 \\
\hline & $\mathbf{0}$ & $\mathbf{0}$ & $\mathbf{0}$ & $\mathbf{0}$ & $\mathbf{0}$ & $\mathbf{0}$ & $\mathbf{0}$ & $\mathbf{0}$ \\
\hline & $\mathbf{0}$ & $\mathbf{0}$ & 0 & 0 & 0 & 0 & 0 & $\mathbf{0}$ \\
\hline & $\mathbf{0}$ & 0 & 0 & 0 & 0 & 0 & $\mathbf{0}$ & 0 \\
\hline & 0 & 0 & 0 & $\mathbf{0}$ & 0 & $\mathbf{0}$ & 0 & 0 \\
\hline \multirow{5}{*}{ 72horas } & 0 & 0 & 0 & 0 & 0 & 0 & 0 & 0 \\
\hline & $\mathbf{0}$ & $\mathbf{0}$ & $\mathbf{0}$ & $\mathbf{0}$ & $\mathbf{0}$ & 0 & $\mathbf{0}$ & $\mathbf{0}$ \\
\hline & $\mathbf{0}$ & $\mathbf{0}$ & $\mathbf{0}$ & $\mathbf{0}$ & 0 & 0 & 0 & $\mathbf{0}$ \\
\hline & $\mathbf{0}$ & 0 & 0 & 0 & 0 & 0 & $\mathbf{0}$ & 0 \\
\hline & 0 & 0 & 0 & 0 & 0 & 0 & 0 & 0 \\
\hline Total & 0 & 0 & 0 & 0 & 0 & 0 & 0 & 0 \\
\hline$\div$ pelo & $0: 15=$ & $0: 15=$ & $0: 15=$ & $0: 15=$ & $0: 15=$ & $0: 15=$ & $0: 15=$ & $0: 15=$ \\
\hline $\begin{array}{l}\text { Número de } \\
\text { observações }\end{array}$ & 0,00 & 0,00 & 0,00 & 0,00 & 0,00 & 0,00 & 0,00 & 0,00 \\
\hline \multirow{6}{*}{ Somas } & \multicolumn{4}{|c|}{ Soma dos eritemas dos extratos } & \multicolumn{4}{|c|}{ Soma dos eritemas dos solventes } \\
\hline & \multicolumn{4}{|c|}{$0,00+0,00=0,00$} & \multicolumn{4}{|c|}{$0,00+0,00=0,00$} \\
\hline & \multicolumn{4}{|c|}{ Soma dos edemas dos extratos } & \multicolumn{4}{|c|}{ Soma dos edemas dos solventes } \\
\hline & \multicolumn{4}{|c|}{$0,00+0,00=0,00$} & \multicolumn{4}{|c|}{$0,00+0,00=0,00$} \\
\hline & \multicolumn{4}{|c|}{ Soma dos edemas e eritemas dos extratos } & \multicolumn{4}{|c|}{ Soma dos edemas e eritemas dos solventes } \\
\hline & \multicolumn{4}{|c|}{$0,00+0,00=0,00$} & \multicolumn{4}{|c|}{$\mathbf{0 , 0 0 + 0 , 0 0 = \mathbf { 0 , 0 0 }}$} \\
\hline \multicolumn{2}{|c|}{$\begin{array}{c}\text { Subtração } \\
\text { Extrato - Solvente. }\end{array}$} & \multicolumn{7}{|c|}{$\begin{array}{l}\text { Contagem de Irritação Primária para A4 } \\
\qquad \mathrm{CIP}=0,00-0,00=0,00\end{array}$} \\
\hline
\end{tabular}

Tabela 18.5 - Planilha de resultados para Contagem de Irritação Primária. Coelho A5

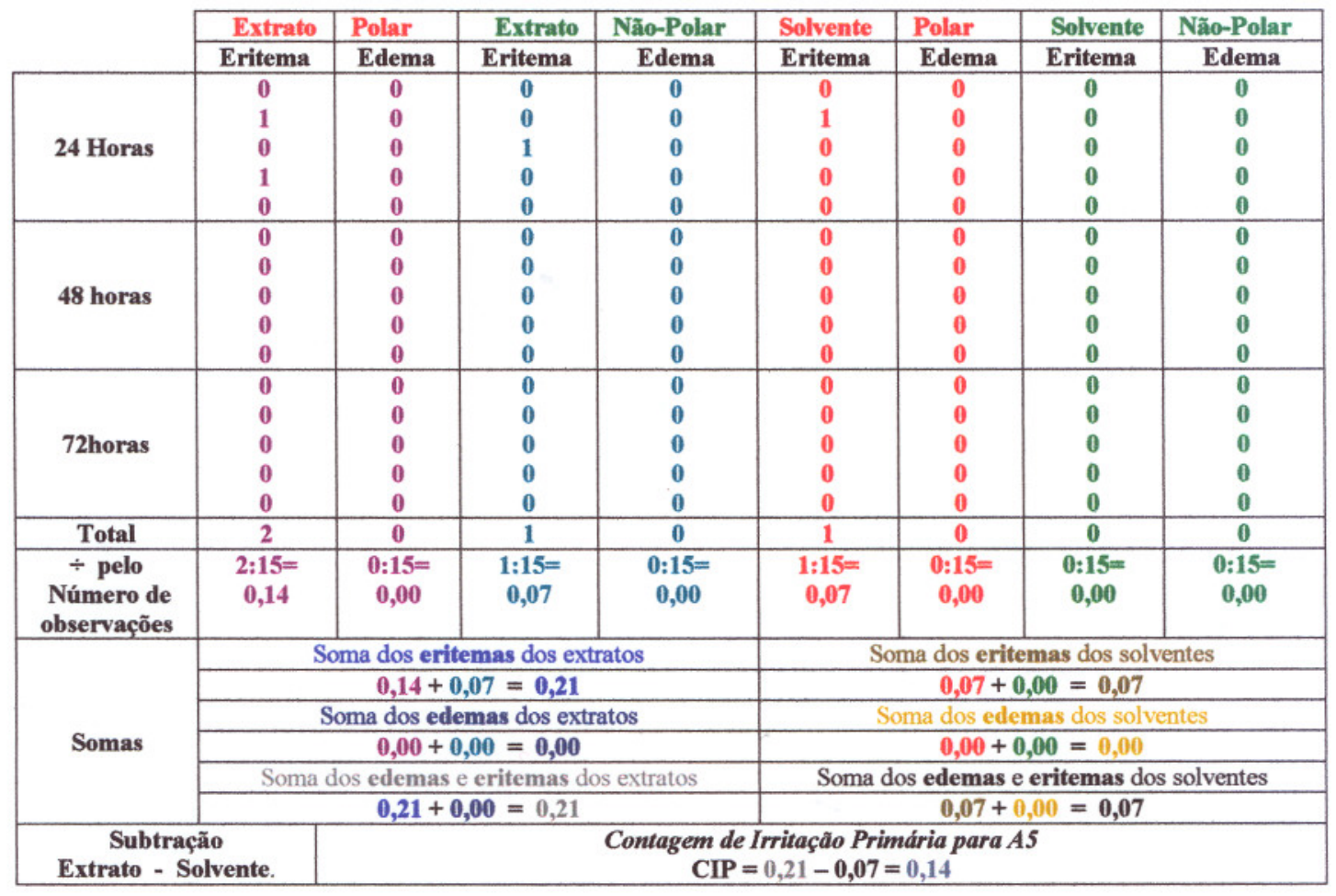




\section{Apêndice II}

\subsection{Tabelas e gráficos com os dados histomorfométricos e estatísticos.}

O tratamento estatístico foi aplicado devido a variabilidade entre indivíduos de uma mesma espécie (Tabelas de 19.1 a 19.18). Para as medidas pareadas e não paramétricas foi utilizado o teste estatístico de Wilcoxon unicaudal (tíbias com e sem PVDF, tíbias com e sem PVDF - com exercício, e tíbias com e sem PVDF - sem exercício) e para as medidas nãopareadas e não-paramétricas, o teste de Mann-Whitney unicaudal (tíbias com e sem exercício - com PVDF e tíbias com e sem exercício - sem PVDF). As diferenças entre os diversos parâmetros analisados foram consideradas significantes para os valores de $\mathrm{P}<0,05$ (assinalados por “․․ㄹ. ) e não significantes para os valores de $\mathrm{P}>0,05$ (assinalados por " $n$ ") Os gráficos (Figuras de 19.1 a 19.18) correspondem às médias dos grupos citados. 
Tabeia 19.1 - Planilha contendo vaiores mensurados e estatísticos de área total óssea, mineralizada ou não.

\begin{tabular}{|c|c|c|c|c|c|c|}
\hline & \multicolumn{2}{|c|}{ Sem exercício } & \multicolumn{2}{|c|}{ Com exercício } & \multicolumn{2}{|c|}{ TOTAL } \\
\hline & Com PVDF & Sem PVDF & Com PVDF & Sem PVDF & Com PVDF & Sem PVDY \\
\hline & 1,77 & 1,21 & 1,60 & 1,41 & 1,77 & 1,21 \\
\hline & 2,34 & 2,30 & 1,19 & 0,89 & 2,34 & 2,30 \\
\hline & 4,21 & 1,76 & 2,55 & 2,50 & 4,21 & 1,76 \\
\hline & 2,67 & 2,87 & 2,39 & 1,59 & 2,67 & 2,87 \\
\hline \multirow[t]{2}{*}{ ÁREA ÓSSEA } & 4,99 & 4,83 & 2,88 & 3,65 & 4,99 & 4,83 \\
\hline & 4,26 & 2,78 & 2,58 & 2,64 & 4,26 & 2,78 \\
\hline \multirow[t]{9}{*}{ (B.Ar) } & 2,36 & 0,96 & $i, 24$ & 1,08 & 2,36 & 0,96 \\
\hline & 1,13 & 1,12 & & & 1,13 & 1,12 \\
\hline & & & & & 1,60 & 1,41 \\
\hline & & & & & 1,19 & 0,89 \\
\hline & & & & & 2,55 & 2,50 \\
\hline & & & & & 2,39 & 1,59 \\
\hline & & & & & 2,88 & 3,65 \\
\hline & & & & & 2,58 & 2,64 \\
\hline & & & & & 1,24 & 1,08 \\
\hline Múédia & 2,97 & 2,23 & 2,06 & 1,97 & 2,54 & 2,11 \\
\hline Desvio Padrão & 1,36 & 1,29 & 0,70 & 1,00 & 1,16 & 1,13 \\
\hline Frro Padrão da Mćdia & 0,48 & 0,46 & 0,26 & 0,38 & 0,30 & 0,29 \\
\hline Minimo & 1,13 & 0,96 & 1,19 & 0,89 & 1,13 & 0,89 \\
\hline Máximo & 4,99 & 4,83 & 2,88 & 3,65 & 4,99 & 4,83 \\
\hline Número & 8 & 8 & 7 & 7 & 15 & 15 \\
\hline \multirow{2}{*}{\multicolumn{7}{|c|}{$\begin{array}{l}\text { Wilcoxon, } \\
\text { Parcado }\end{array}$}} \\
\hline & & & & & & \\
\hline \multirow{2}{*}{$\begin{array}{l}\text { Não Paramétrico; } \\
\text { Unicaudal }\end{array}$} & $*$ & & ns & & $\sqrt{*}$ & \\
\hline & 0,03 & $\mathrm{~W}=$ & 0,19 & $\mathrm{~W}=$ & 0,02 & $\mathrm{~W}=$ \\
\hline \multirow{5}{*}{$\begin{array}{l}\text { Mann-Whitney, } \\
\text { Não-pareado; } \\
\text { Não Paramétrico } \\
\text { Unicaudal }\end{array}$} & ns & & & & & \\
\hline & 0,20 & & MW & & & \\
\hline & & & & & & \\
\hline & & & & & & \\
\hline & & $\frac{\text { ns }}{0,35}$ & & MW & & \\
\hline
\end{tabular}

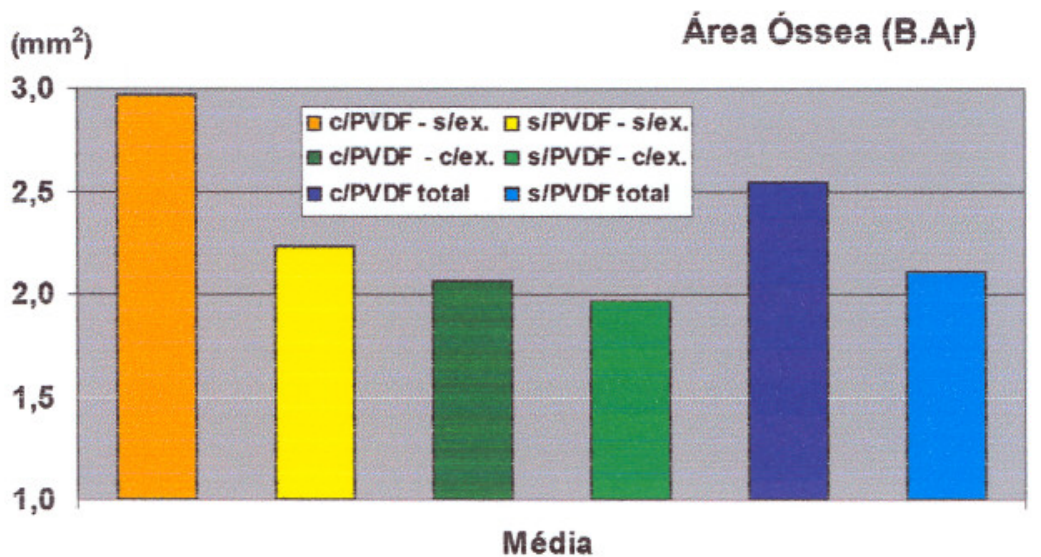

Figura 19.1 - Gráfico dos valores médios para área óssea total. ( $c / P V D F-s / e x$ - com PVDF, sem exercício); (s/PVDF-s/ex. - sem PVDF, sem exercício); ( $c / P V D F-c / e x$ - com PVDF, com exercício); (s/PVDF-c/ex. - sem PVDF, com exercício); ( $/$ PVDF-total. - todos os dados com PVDF); (s/PVDF total. - todos os dados sem PVDF). 
Tabeia 19.2 - Pianilha contendo valores mensurados e estatísticos de volume de osso totai, minerailizado ou não.

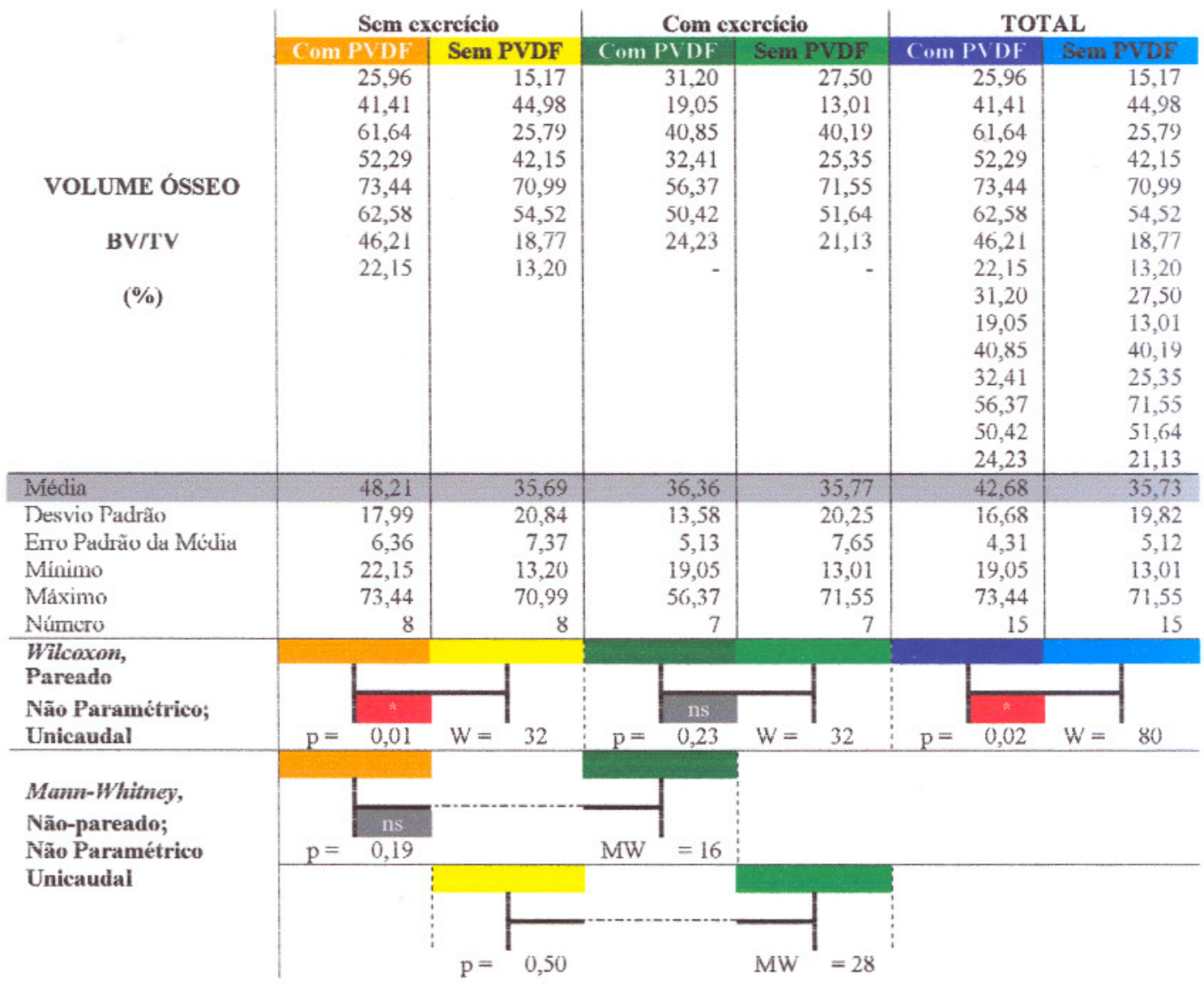

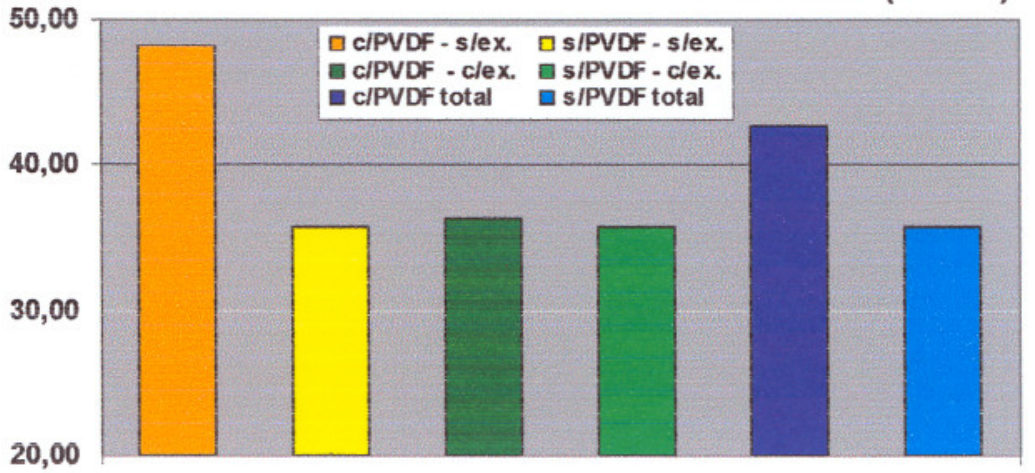

Média

Figura 19.2 - Gráfico dos valores médios para volume de osso total. (c/PVDF-s/ex. - com PVDF, sem exercício); (s/PVDF-s/ex. - sem PVDF, sem exercício); (c/PVDF-c/ex. - com PVDF, com exercício); (s/PVDF-c/ex - sem PVDF, com exercício); (c/PVDF-total. - todos os dados com PVDF); (s/PVDF total. - todos os dados sem PVDF). 
Tabeia 19.3 - Planilha contendo valores mensurados e estatísticos de área de osso mineralizado.

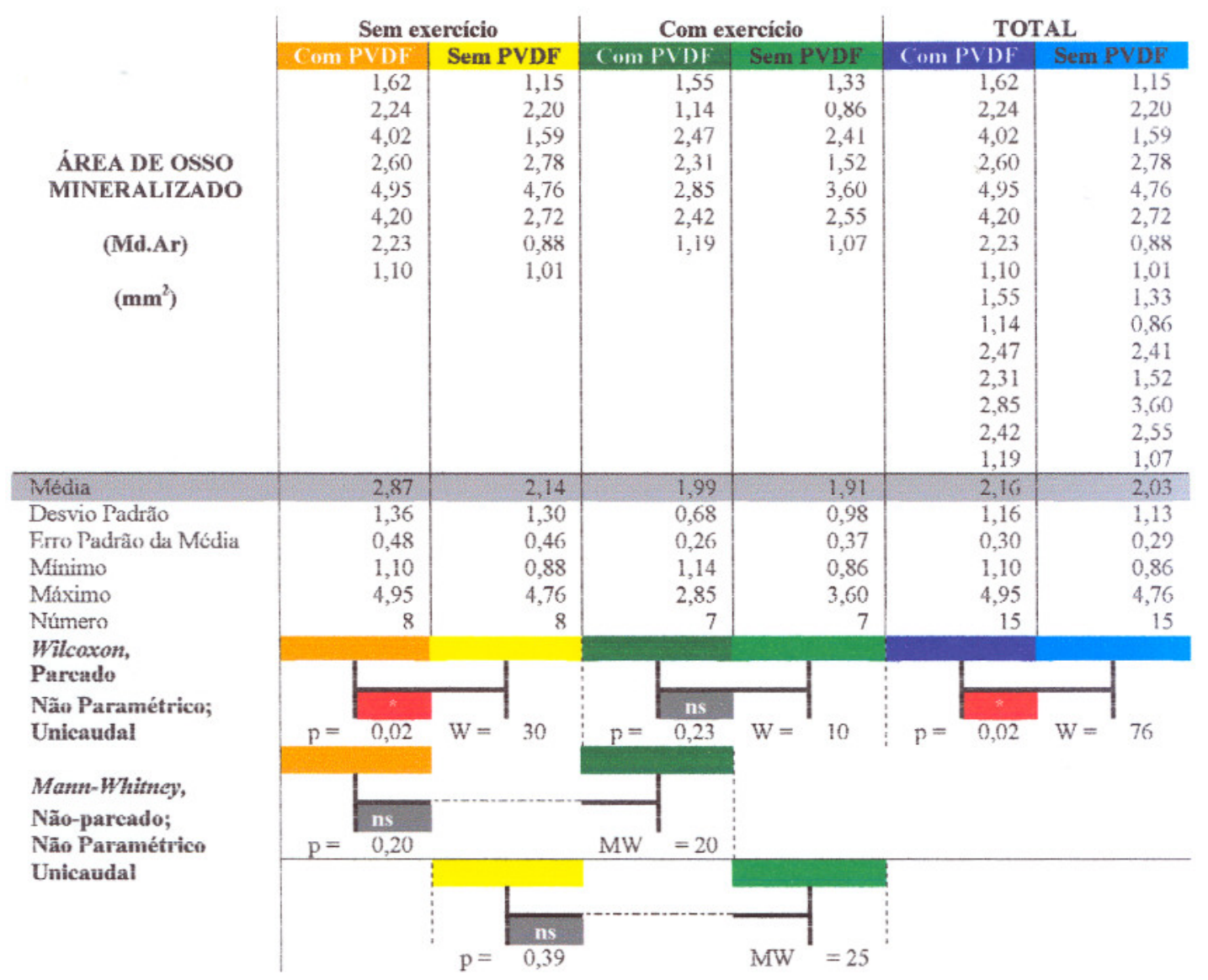

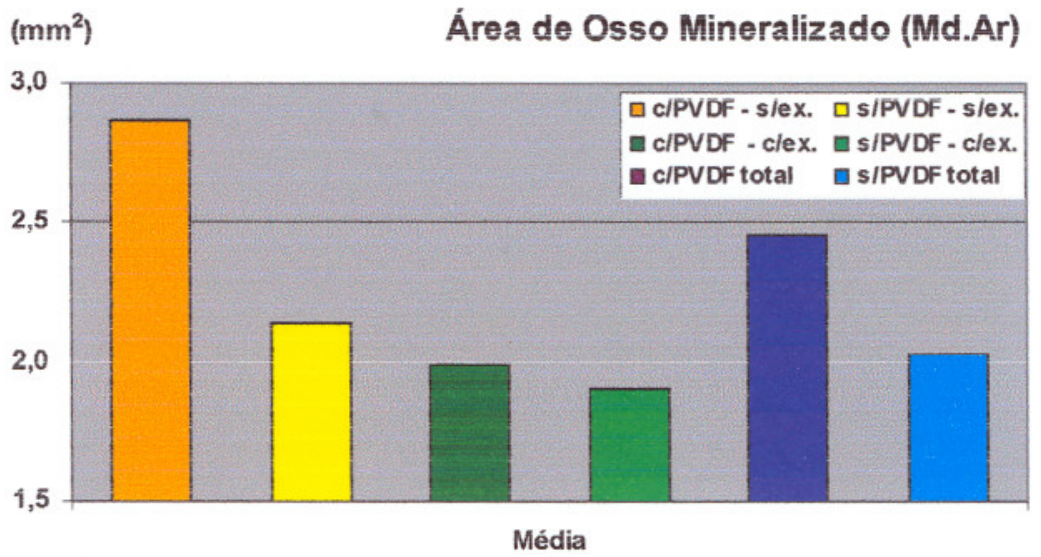

Figura 19.3 - Gráfico dos valores médios para área de osso mineralizado total. ( $/ P V D F-s / e x$ - com PVDF, sem exercício); (s/PVDF-s/ex. - sem PVDF, sem exercício); (c/PVDF-c/ex. - com PVDF, com exercício); (s/PVDF-c/ex. - sem PVDF, com exercício); (c/PVDF-total. - todos os dados com PVDF); (s/PVDF total. - todos os dados sem PVDF). 
Tabela 19.4 - Planilha contendo vaiores mensurados e estatísticos de área medular.

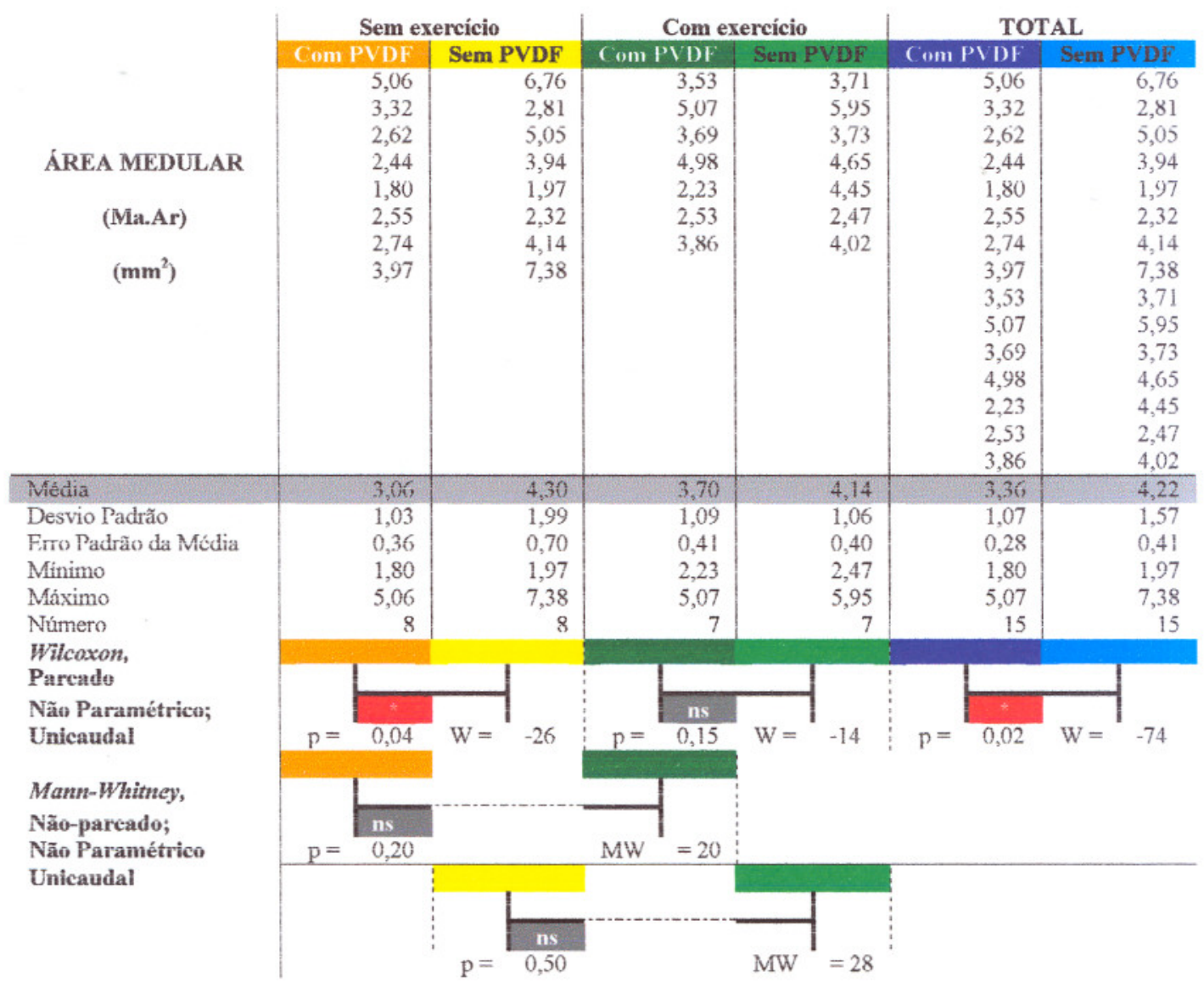

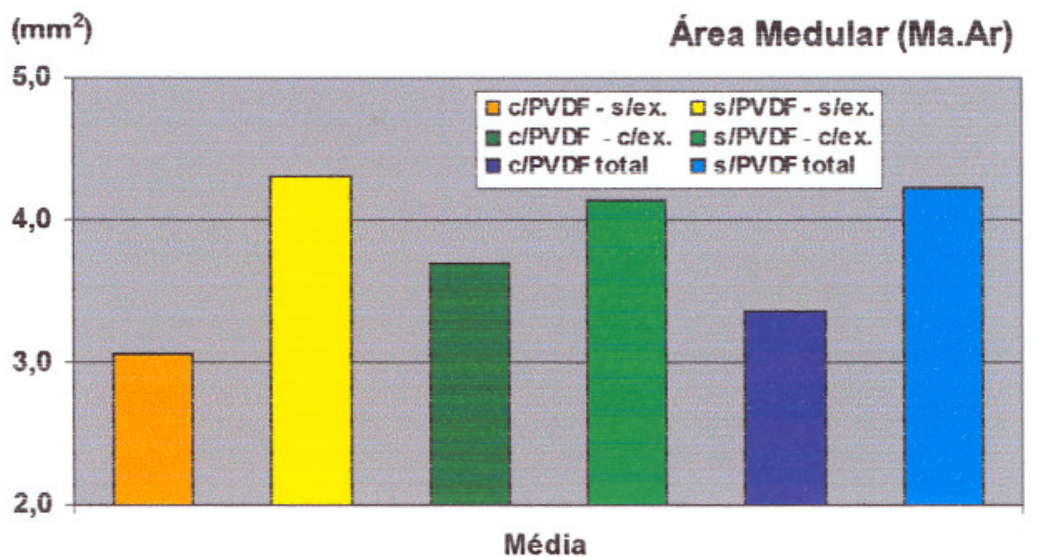

Figura 19.4 - Gráfico dos valores médios para área medular. (c/PVDF-s/ex - com PVDF, sem exercício); (s/PVDF-s/ex. - sem PVDF, sem exercício); (c/PVDF-c/ex. - com PVDF, com exercício); (s/PVDF-c/ex. - sem PVDF, com exercício); (c/PVDF-total. - todos os dados com PVDF); (s/PVDF total. - todos os dados sem PVDF). 
Tabela 19.5 - Planilha contendo vaiores mensurados e estatísticos de área osteóide.

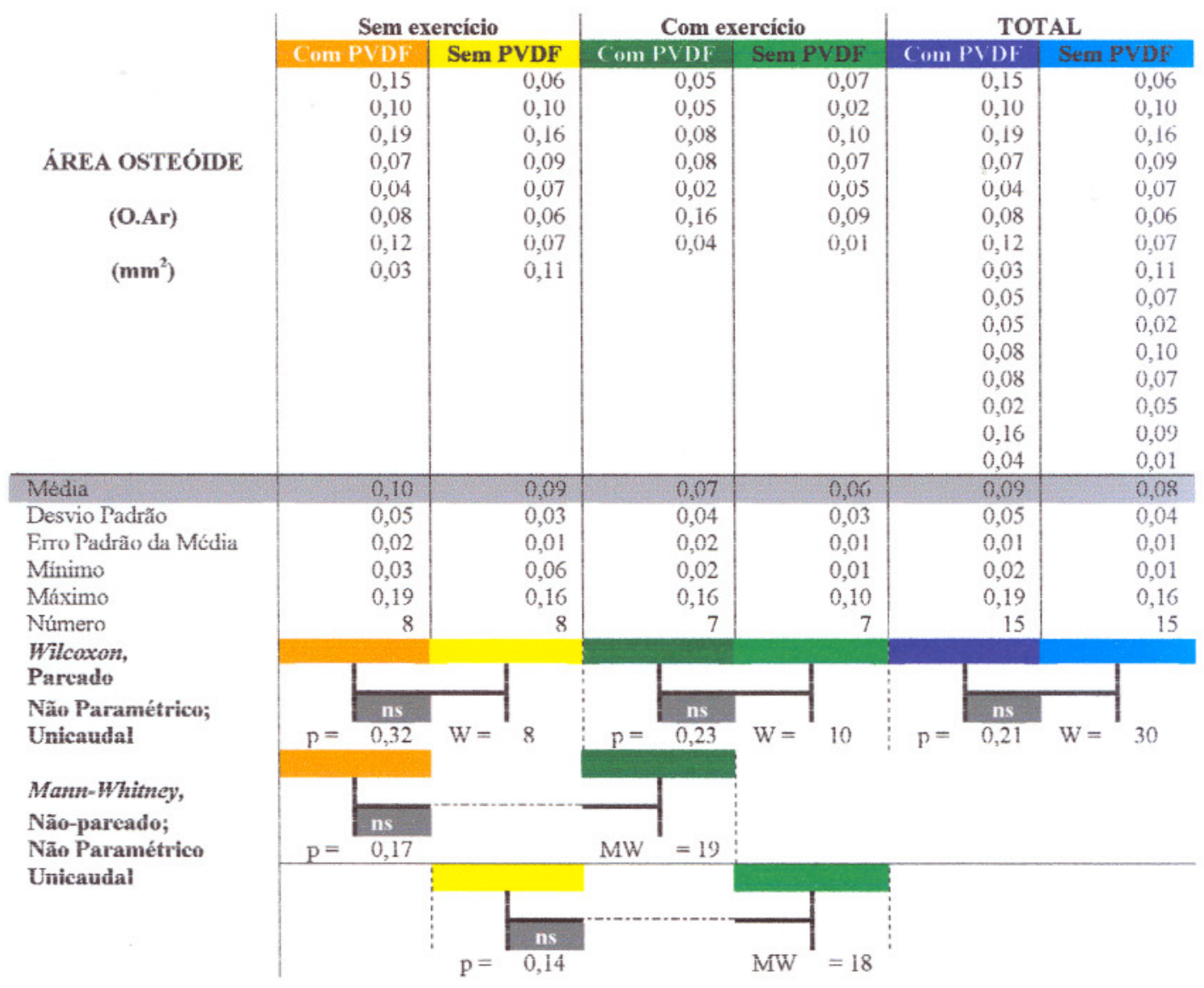

$\left(\mathrm{mm}^{2}\right)$

Área Osteóide (O.Ar)

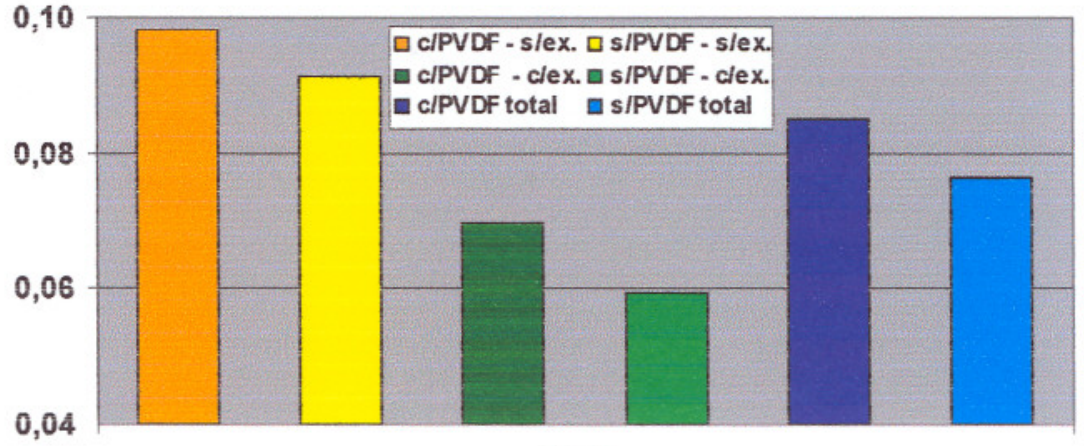

Média

Figura 19.5 - Gráfico dos valores médios para área osteóide. ( $c / P V D F-s / e x$ - com PVDF, sem exercício); (s/PVDF-s/ex. - sem PVDF, sem exercício); (c/PVDF-c/ex - com PVDF, com exercício); (s/PVDF-c/ex. - sem PVDF, com exercício); (c/PVDF-total. - todos os dados com PVDF); ( $s /$ PVDF total. - todos os dados sem PVDF). 
Tabela 19.6 - Pianiiha contendo valores mensurados e estatísticos de espessura osteóide.

\begin{tabular}{|c|c|c|c|c|c|c|}
\hline & \multicolumn{2}{|c|}{ Sem exercício } & \multicolumn{2}{|c|}{ Com exercício } & \multicolumn{2}{|c|}{ TOTAL } \\
\hline & Com PVDF & Sem PVDF & Com PVDF & Sem PVDF & Com PVDF & Sem PVDF \\
\hline & 3,69 & 2,84 & 2,64 & 3,50 & 3,69 & 2,84 \\
\hline & 3,44 & 2,55 & 2,70 & 2,71 & 3,44 & 2,55 \\
\hline & 3,48 & 5,19 & 2,89 & 4,25 & 3,48 & 5,19 \\
\hline \multirow{3}{*}{$\begin{array}{l}\text { ESPESSURA } \\
\text { OSTEÓIDE }\end{array}$} & 3,07 & 3,15 & 3,18 & 3,16 & 3,07 & 3,15 \\
\hline & 1,71 & 2,30 & 1,59 & 2,42 & 1,71 & 2,30 \\
\hline & 2,51 & 2,00 & 4,31 & 2,95 & 2,51 & 2,00 \\
\hline \multirow[t]{2}{*}{ (O.Th) } & 2,70 & 3,39 & 2,44 & 1,36 & 2,70 & 3,39 \\
\hline & 2,67 & 4,65 & & & 2,67 & 4,65 \\
\hline \multirow[t]{7}{*}{$(\mu \mathrm{m})$} & & & & & 2,64 & 3,50 \\
\hline & & & & & 2,70 & 2,71 \\
\hline & & & & & 2,89 & 4,25 \\
\hline & & & & & 3,18 & 3,16 \\
\hline & & & & & 1,59 & 2,42 \\
\hline & & & & & 4,31 & 2,95 \\
\hline & & & & & 2,44 & 1,36 \\
\hline Míedia & $2,9 i$ & 3,26 & 2,82 & 2,91 & 2,87 & 3,10 \\
\hline Desvio Padrão & 0,65 & 1,13 & 0,82 & 0,90 & 0,71 & 1,01 \\
\hline Frro Padrão da Média & 0,23 & 0,40 & 0,31 & 0,34 & 0,18 & 0,26 \\
\hline Mínimo & 1,71 & 2,00 & 1,59 & 1,36 & 1,59 & 1,36 \\
\hline Máximo & 3,69 & 5,19 & 4,31 & 4,25 & 4,31 & 5,19 \\
\hline Númcro & 8 & 8 & 7 & 7 & 15 & 15 \\
\hline \multirow{2}{*}{\multicolumn{7}{|c|}{$\begin{array}{l}\text { Wilcoxon, } \\
\text { Pareade }\end{array}$}} \\
\hline & & & & & & \\
\hline \multirow{2}{*}{$\begin{array}{l}\text { Não Paramétrico; } \\
\text { Unicaudal }\end{array}$} & ns & & ns & & ns & \\
\hline & 0,27 & $\mathrm{~W}=$ & 0,41 & $\mathrm{~W}=$ & 0,23 & $W=$ \\
\hline \multicolumn{7}{|l|}{ Mann-Whitney, } \\
\hline \multirow{4}{*}{$\begin{array}{l}\text { Não-parcado; } \\
\text { Não Paramétrico } \\
\text { Unicaudal }\end{array}$} & ns & & & & & \\
\hline & 0,31 & & MW & & & \\
\hline & & & & & & \\
\hline & & $\begin{array}{c}\text { ns } \\
0,43\end{array}$ & & MW & & \\
\hline
\end{tabular}

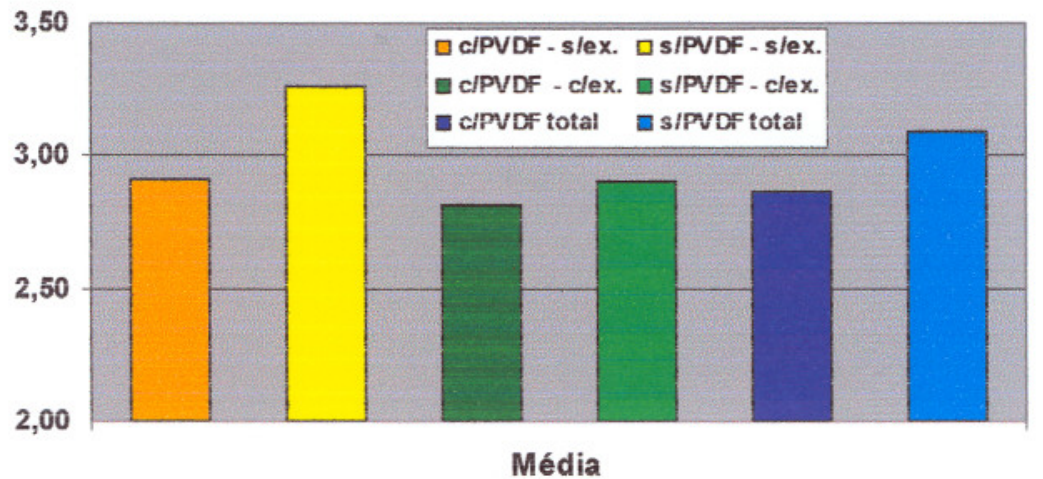

Figura 19.6 Gráfico dos vaiores médios para espessura osteóide. ( $/ P V D F-s / e x$ - com PVDF, sem exercício); (s/PVDF-s/ex. - sem PVDF, sem exercício); (c/PVDF-c/ex. - com PVDF, com exercício); (s/PVDF-c/ex - sem PVDF, com exercício); (c/PVDF-total. - todos os dados com PVDF); (s/PVDF total. - todos os dados sem PVDF). 
Tabeia 19.7 - Planilha contendo valores mensurados e estatísticos de superfície osteóide.

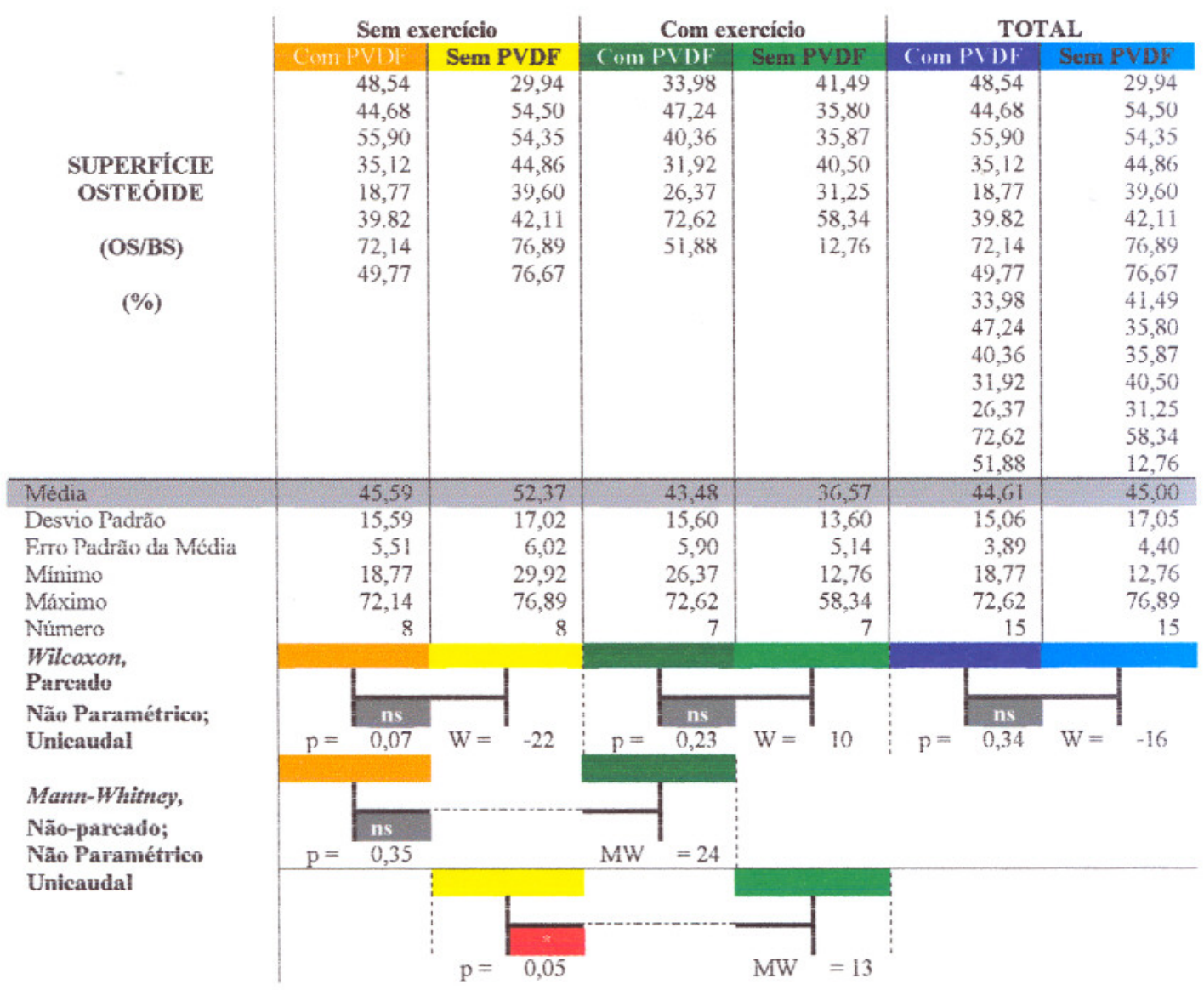

Superficie Osteóide (OS/BS)

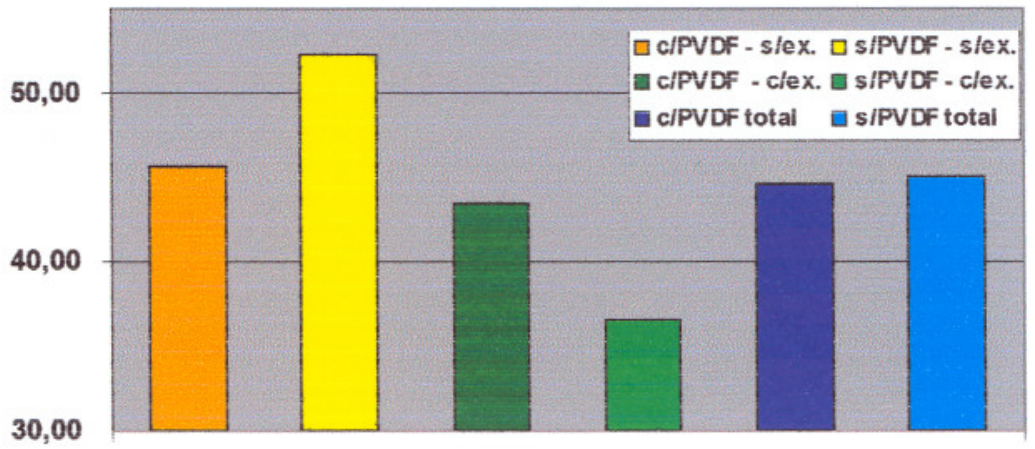

Média

Figura 19.7 - Gráfico dos valores médios para superfície osteóide. ( $c / P V D F-s / e x$ - com PVDF, sem exercício); (s/PVDF-s/ex. - sem PVDF, sem exercício); (c/PVDF-c/ex. - com PVDF, com exercício); (s/PVDF-c/ex. - sem PVDF, com exercício); (c/PVDF-total. - todos os dados com PVDF); (s/PVDF total. - todos os dados sem PVDF). 
Tabela 19.8 - Pianilha contendo valores mensurados e estatísticos de volume osteóide.

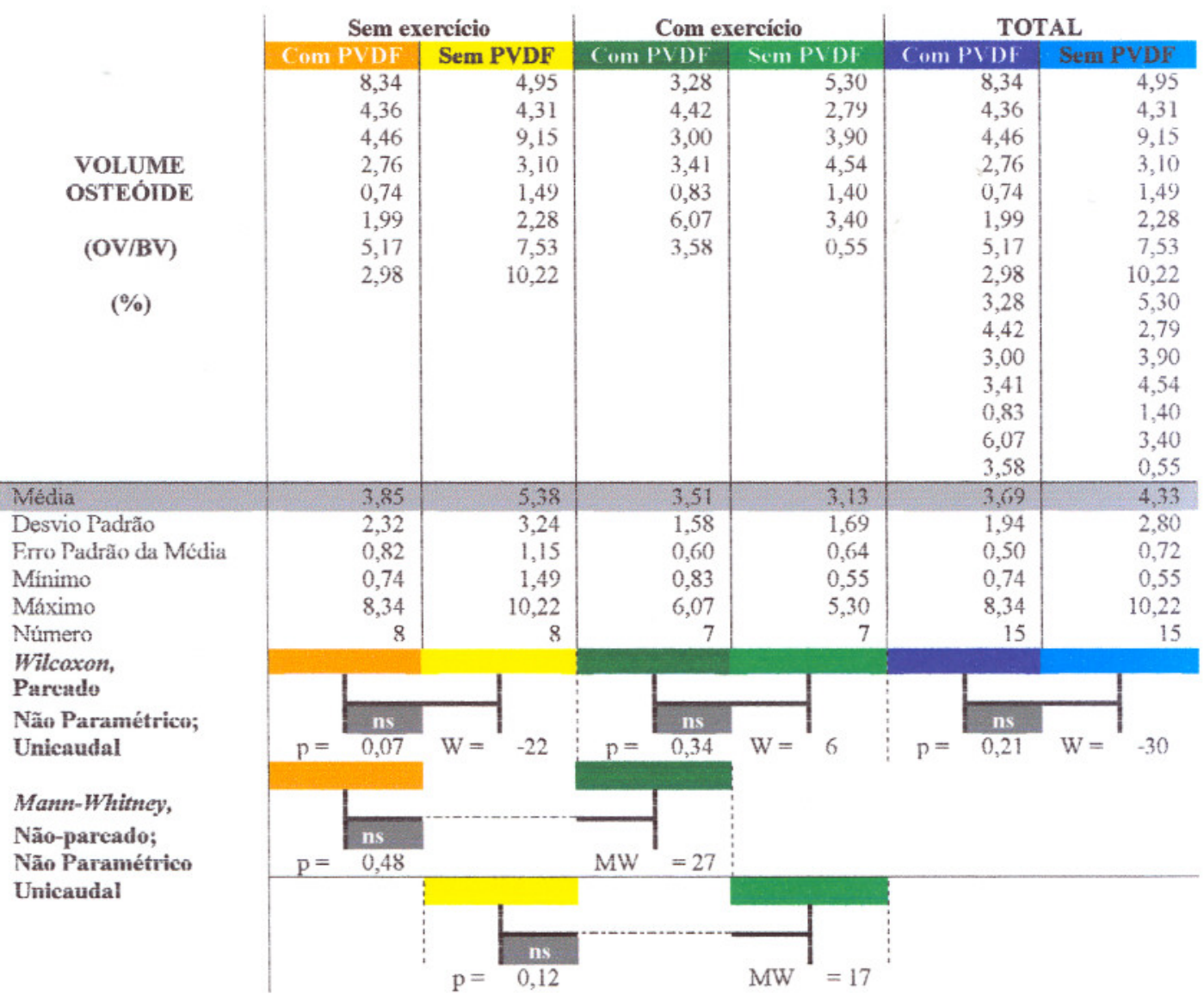

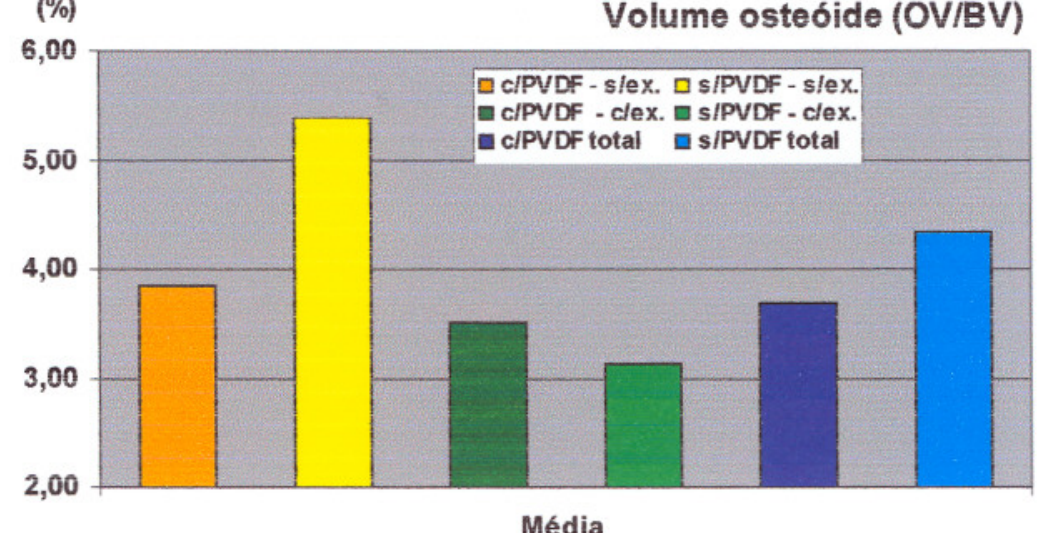

Figura 19.8 - Gráfico dos vaiores médios para volume osteóide. (c/PVDF-s/ex - com PVDF, sem exercício); (s/PVDF-s/ex. - sem PVDF, sem exercício); (c/PVDF-c/ex. - com PVDF, com exercício); (s/PVDF-c/ex. - sem PVDF, com exercício); (c/PVDF-total. - todos os dados com PVDF); (s/PVDF total. - todos os dados sem PVDF). 
Tabeia 19.9 - Planiiha contendo vaiores mensurados e estatísticos de superfície osteobiástica.

\begin{tabular}{|c|c|c|c|c|c|c|}
\hline \multirow{5}{*}{-} & \multicolumn{2}{|c|}{ Sem exercício } & \multicolumn{2}{|c|}{ Com exercício } & \multicolumn{2}{|c|}{ TOTAL } \\
\hline & Com PVDF & Sem PVDF & Com PVDF & Sem PVDF & Com PVDF & Sem PVDF \\
\hline & 20,52 & 15,62 & 20,59 & 26,99 & 20,52 & 15,62 \\
\hline & 24,95 & 26,26 & 26,31 & 21,39 & 24,95 & 26,26 \\
\hline & 31,82 & 45,88 & 26,30 & 23,01 & 31,82 & 45,88 \\
\hline SUPERFICIE & 21,24 & 28,04 & 16,76 & 29,40 & 21,24 & 28,04 \\
\hline \multirow{2}{*}{ OSTEOBLÁSTICA } & 12,43 & 30,97 & 17,15 & 20,29 & 12,43 & 30,97 \\
\hline & 32,72 & 34,11 & 42,86 & 28,01 & 32,72 & 34,11 \\
\hline \multirow[t]{2}{*}{ (Ob.S/BS) } & 39,69 & $3 i, 25$ & 22,63 & 7,59 & 39,69 & 31,25 \\
\hline & 21,58 & 40,90 & & & 21,58 & 40,90 \\
\hline \multirow[t]{7}{*}{$(\%)$} & & & & & 20,59 & 26,99 \\
\hline & & & & & 26,31 & 21,39 \\
\hline & & & & & 26,30 & 23,01 \\
\hline & & & & & 16,76 & 29,40 \\
\hline & & & & & 17,15 & 20,29 \\
\hline & & & & & 42,86 & 28,01 \\
\hline & & & & & 22,63 & 7,59 \\
\hline & 25,62 & 31,63 & 24,66, & 22,38 & 25,17 & 27,31 \\
\hline Desvio Padrão & 8,64 & 9,21 & 8,91 & 7,38 & 8,46 & 9,41 \\
\hline Frro Padrão da Média & 3,06 & 3,26 & 3,37 & 2,79 & 2,18 & 2,43 \\
\hline Minimo & 12,43 & 15,62 & 16,76 & 7,59 & 12,43 & 7,59 \\
\hline Máximo & 39,69 & 45,88 & 42,86 & 29,40 & 42,86 & 45,88 \\
\hline Número & 8 & 8 & 7 & 7 & 15 & 15 \\
\hline \multirow{2}{*}{\multicolumn{7}{|c|}{$\begin{array}{l}\text { Wilcoxon, } \\
\text { Pareado }\end{array}$}} \\
\hline & & & & & & \\
\hline \multirow{2}{*}{$\begin{array}{l}\text { Não Paramétrico; } \\
\text { Unicaudal }\end{array}$} & ns & & $\begin{array}{c}\text { ns } \\
0.29\end{array}$ & & ns & \\
\hline & 0,10 & $W=$ & 0,29 & $W=$ & 0,28 & $W=$ \\
\hline \multicolumn{7}{|l|}{ Mann-Whitncy, } \\
\hline \multirow{4}{*}{$\begin{array}{l}\text { Não-pareado; } \\
\text { Não Paramétrico } \\
\text { Unicaudal }\end{array}$} & ns & & & & & \\
\hline & 0,43 & & MW & & & \\
\hline & & & & & & \\
\hline & & 0,02 & & MW & & \\
\hline
\end{tabular}

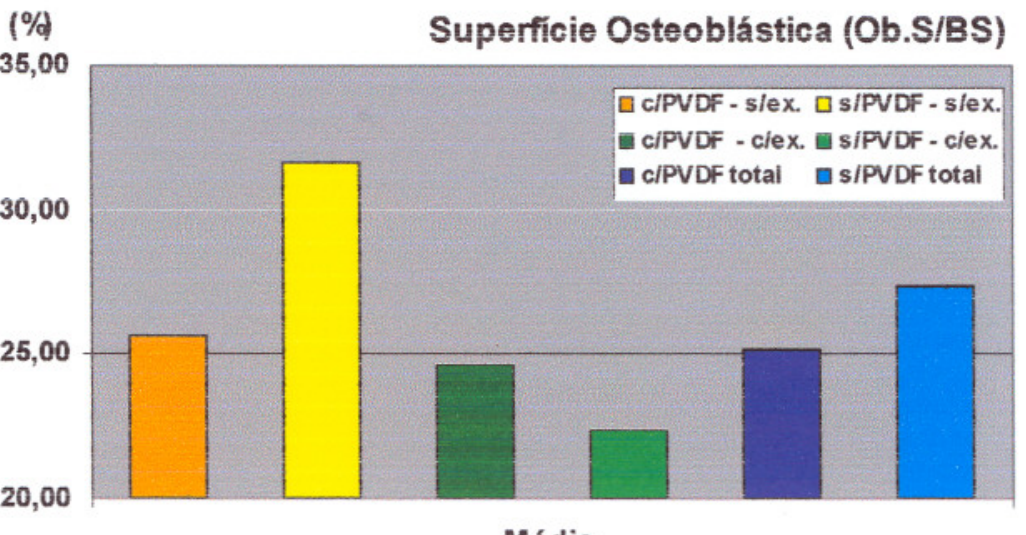

Figura 19.9 - Gráfico dos valores médios para superfície osteoblástica. $(c / P V D F-s / e x$ - com PVDF, sem exercício); (s/PVDF-s/ex. - sem PVDF, sem exercício); (c/PVDF-c/ex. - com PVDF, com exercício); (s/PVDF-c/ex. - sem PVDF, com exercício); (c/PVDF-total. - todos os dados com PVDF); (s/PVDF total. - todos os dados sem PVDF). 
Tabela 19.10 - Pianilha contendo valores mensurados e estatísticos de superfície osteociástica.

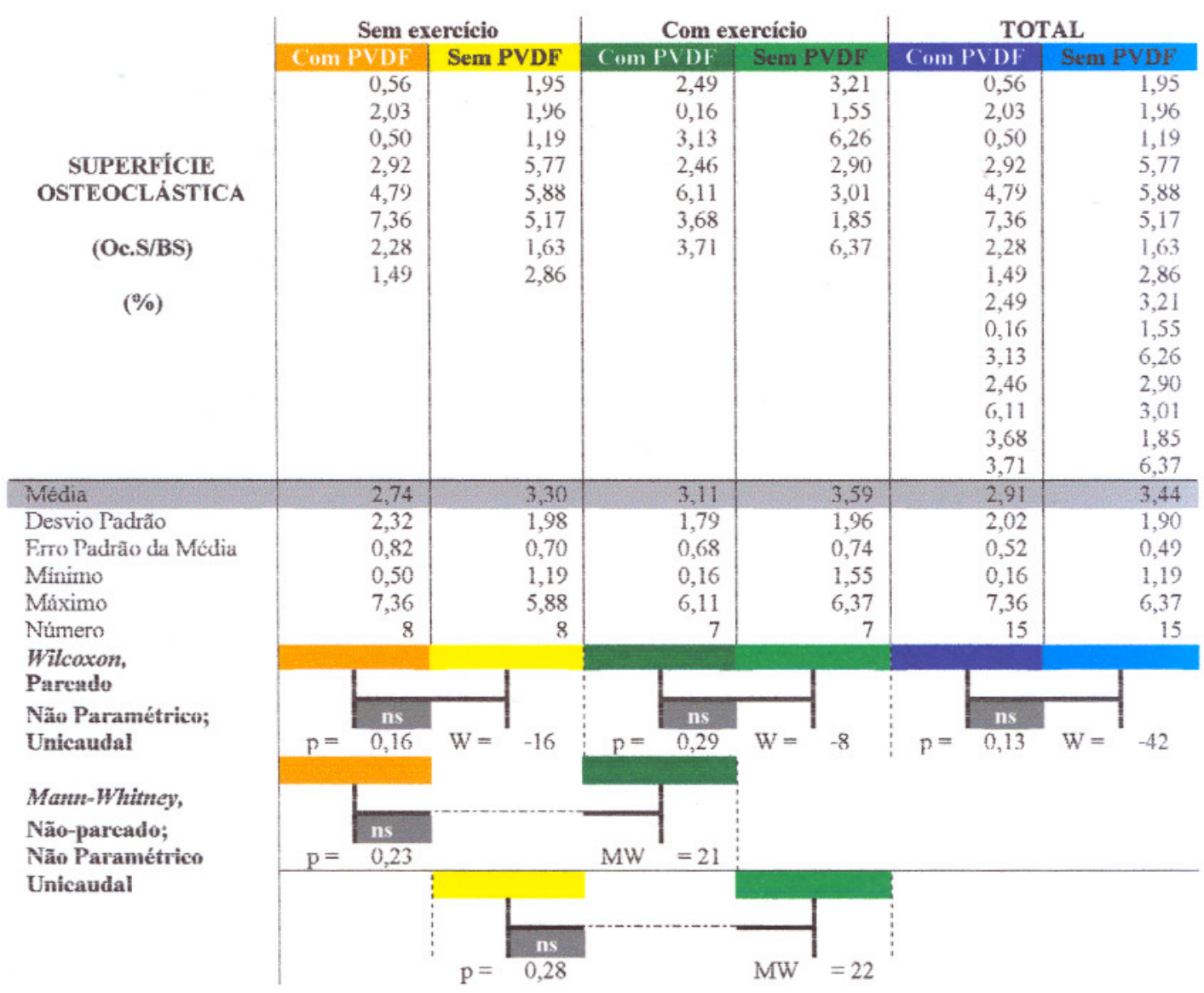

(\%) Superficie Osteoclástica (Oc.S/BS)

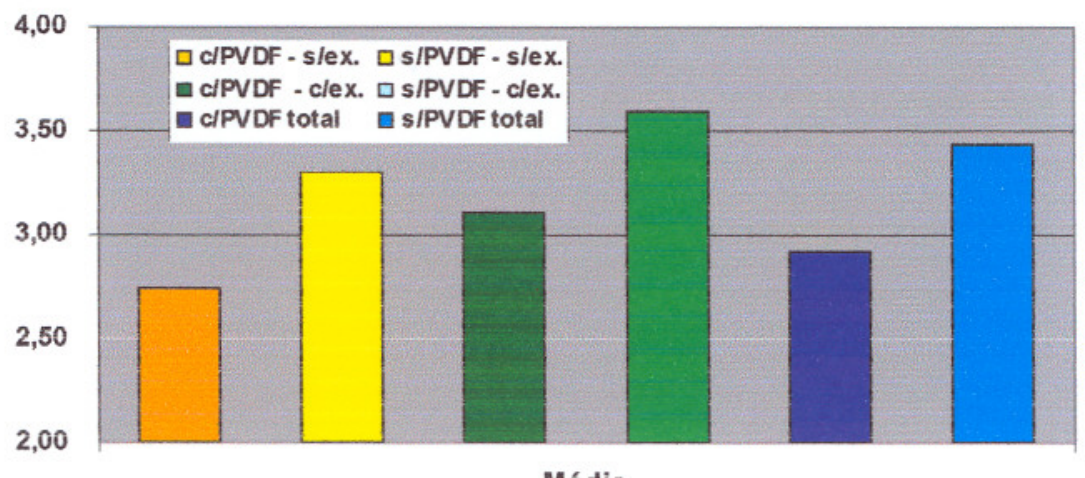

Figura 19.10 - Gráfico dos valores médios para superfície osteoclástica. $(c / P V D F-s / e x$ - com PVDF, sem exercício); (s/PVDF-s/ex - sem PVDF, sem exercício); (c/PVDF-c/ex - com PVDF, com exercício); (s/PVDF-c/ex - sem PVDF, com exercício); (c/PVDF-total. - todos os dados com PVDF); (s/PVDF total. - todos os dados sem PVDF). 
Tabeia 19.11 - Pianilha contendo valores mensurados e estatísticos de superfície de reabsorção.

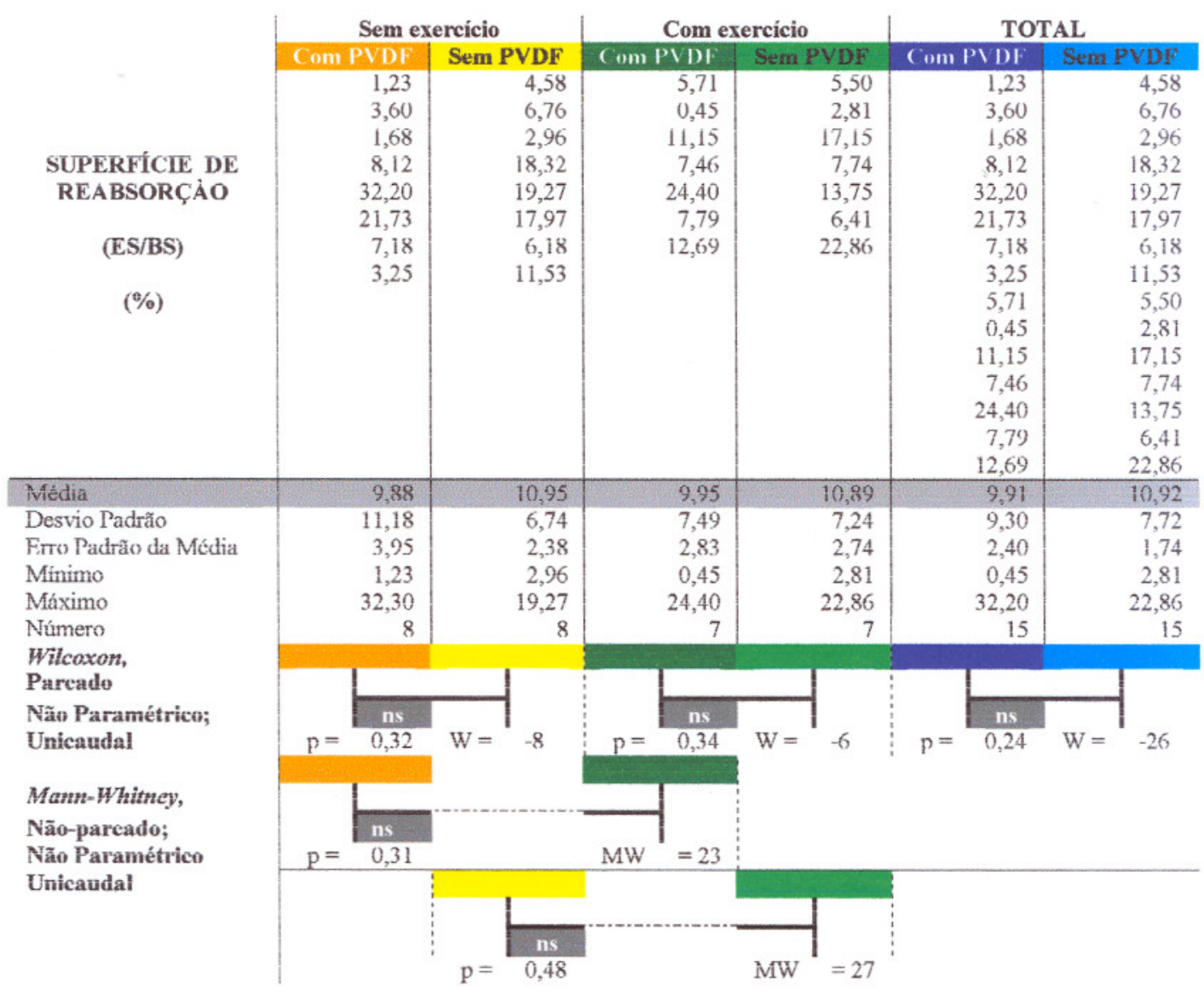

(\%)

Superficie de Reabsorção (ES/BS)

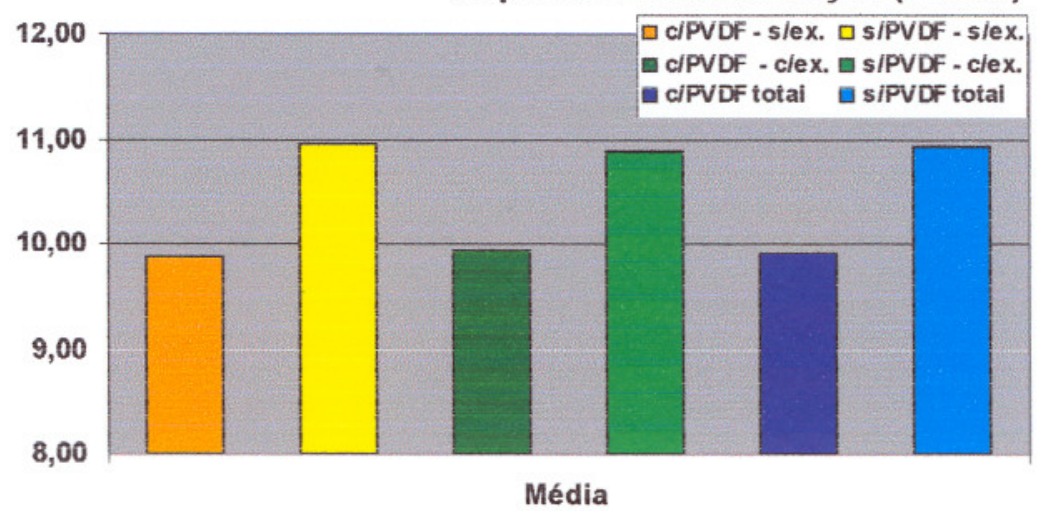

Figura 19.11 - Gráfico dos valores médios para superfície de reabsorção. ( $c / P V D F-s / e x$ - com PVDF, sem exercício); (s/PVDF-s/ex. - sem PVDF, sem exercício); (c/PVDF-c/ex. - com PVDF, com exercício); (s/PVDF-c/ex - sem PVDF, com exercício); (c/PVDF-total. - todos os dados com PVDF); (s/PVDF total. - todos os dados sem PVDF). 
Tabela 19.12 - Planilha contendo valores mensurados e estatísticos de área trabecular.

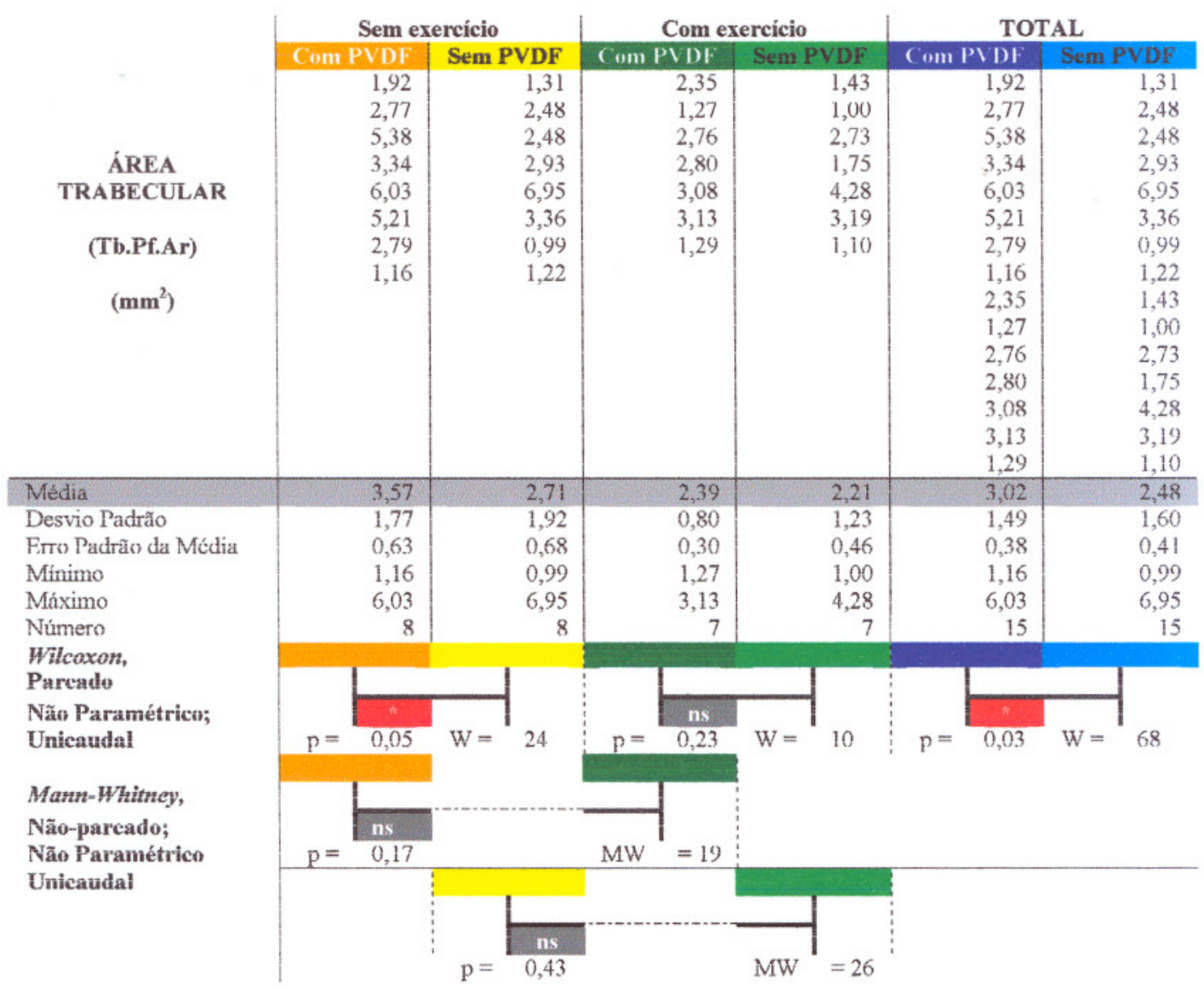

$\left(\mathrm{mm}^{2}\right) \quad$ Área Trabecular (Tb.Pf.Ar)

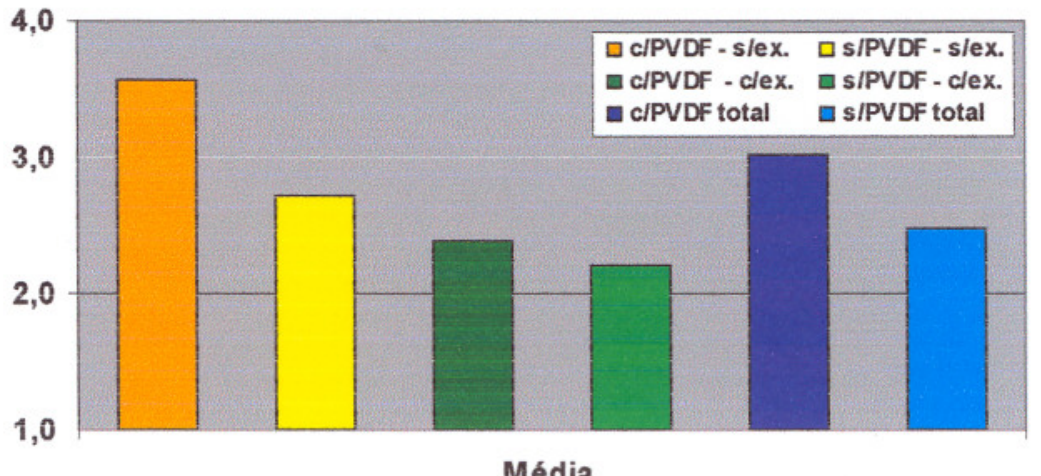

Figura 19.12 - Gráfico dos valores médios para área trabecular. (c/PVDF-s/ex. - com PVDF, sem exercício); (s/PVDF-s/ex. - sem PVDF, sem exercício); (c/PVDF-c/ex. - com PVDF, com exercício); ( $s / P V D F-c / e x$. sem PVDF, com exercício); (c/PVDF-total. - todos os dados com PVDF); (s/PVDF total. - todos os dados sem PVDF). 
Tabeia 19.13 - Planilha contendo vaiores mensurados e estatisticos de espessura trabecular.

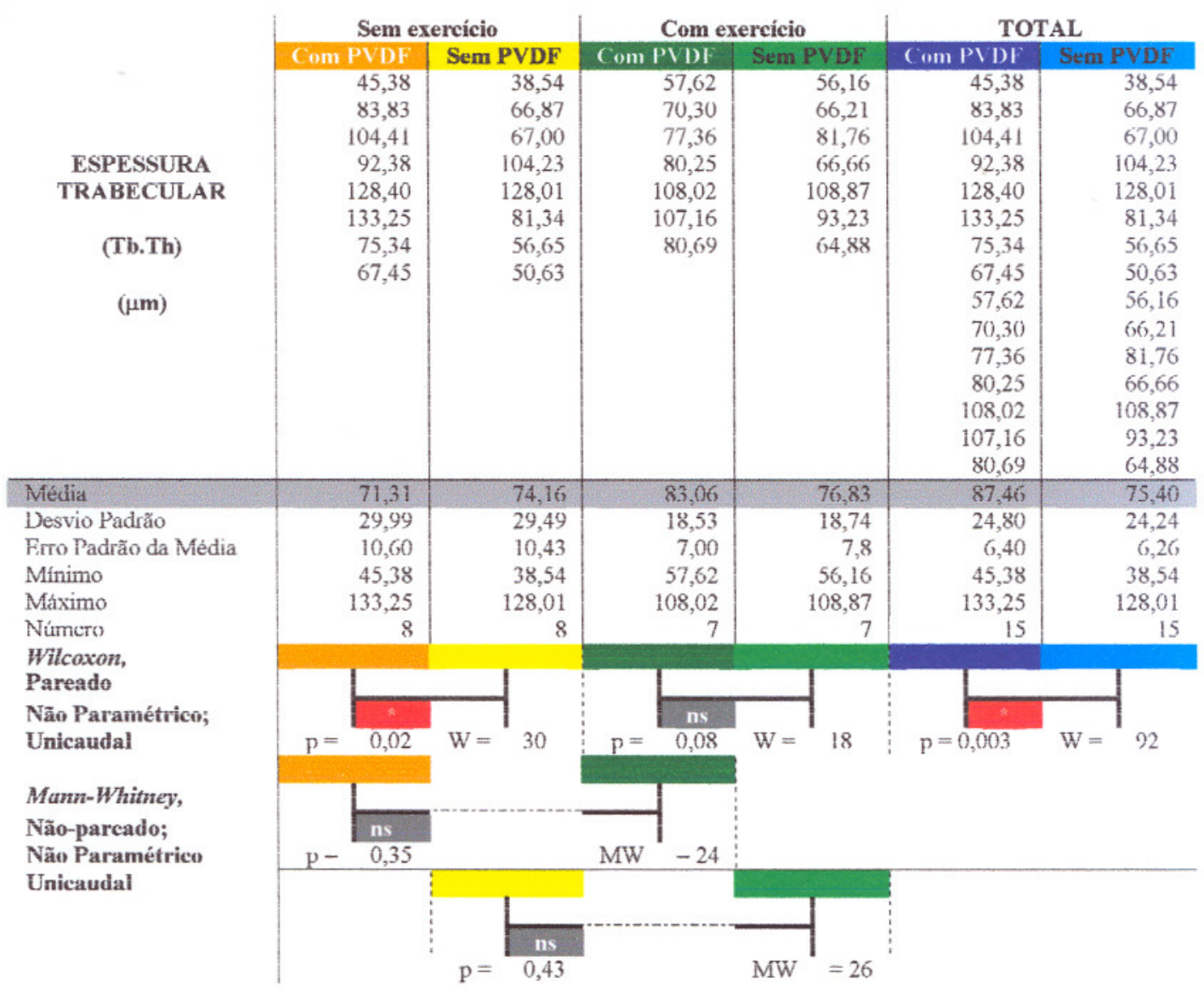

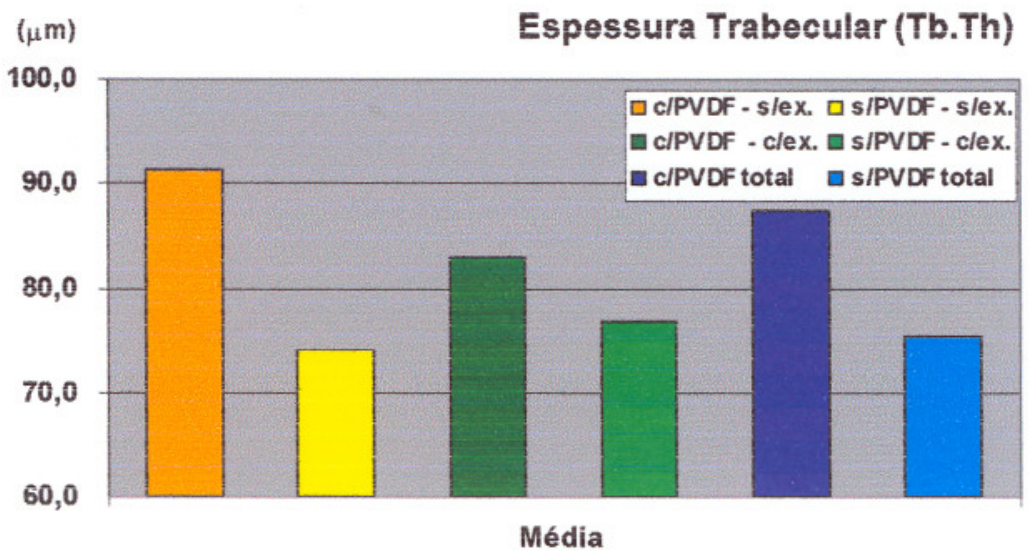

Figura 19.13 - Gráfico dos vaiores médios para espessura trabecular. (c/PVDF-s/ex - com PVDF, sem exercício); (s/PVDF-s/ex - sem PVDF, sem exercício); (c/PVDF-c/ex - com PVDF, com exercício); (s/PVDF-c/ex - sem PVDF, com exercício); (c/PVDF-total. - todos os dados com PVDF); (s/PVDF total. - todos os dados sem PVDF). 
Tabela 19.14 - Planilha contendo valores mensurados e estatisticos de número trabecular.

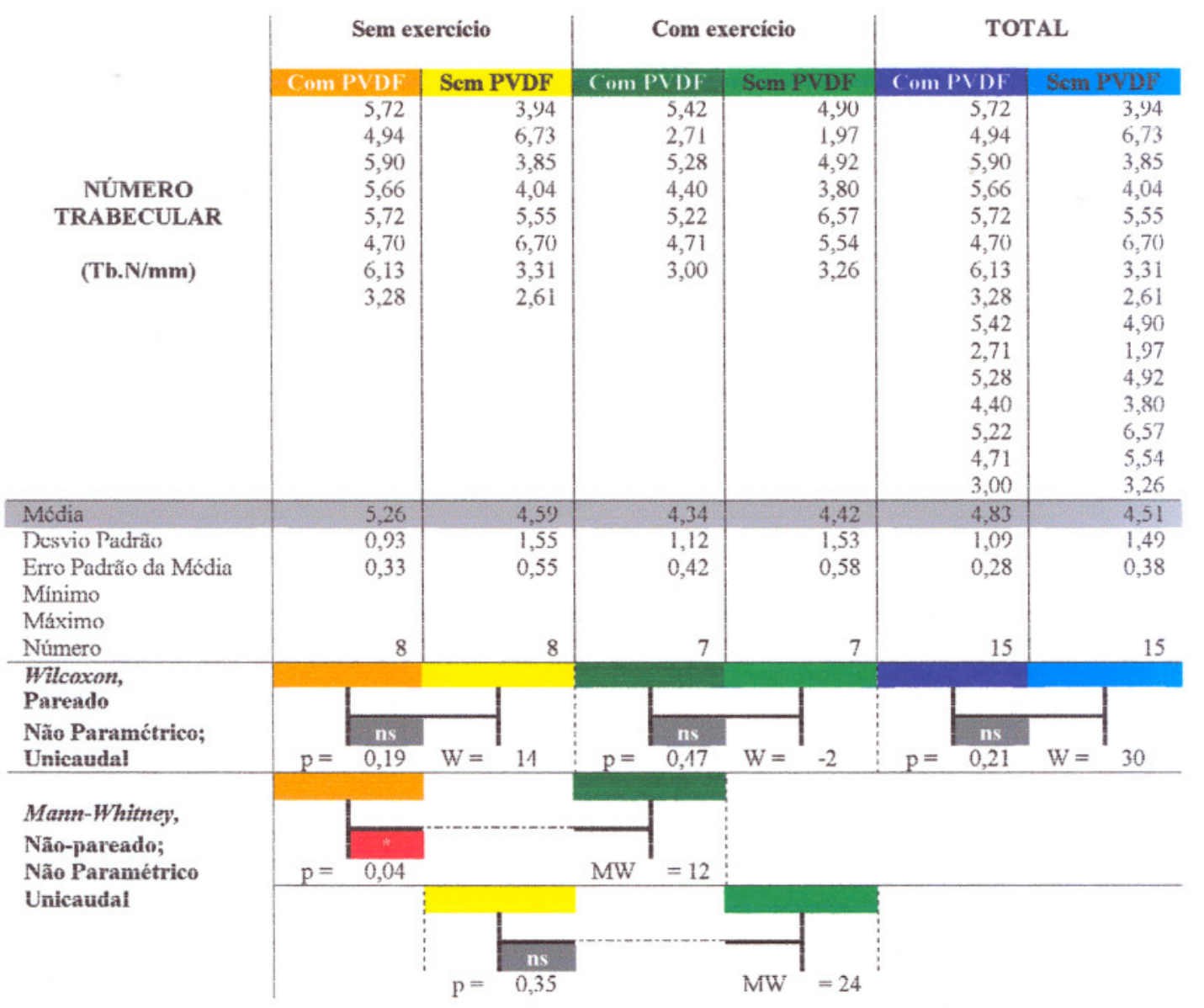

(Tb.N/mm)

Número Trabecular (Tb.N)

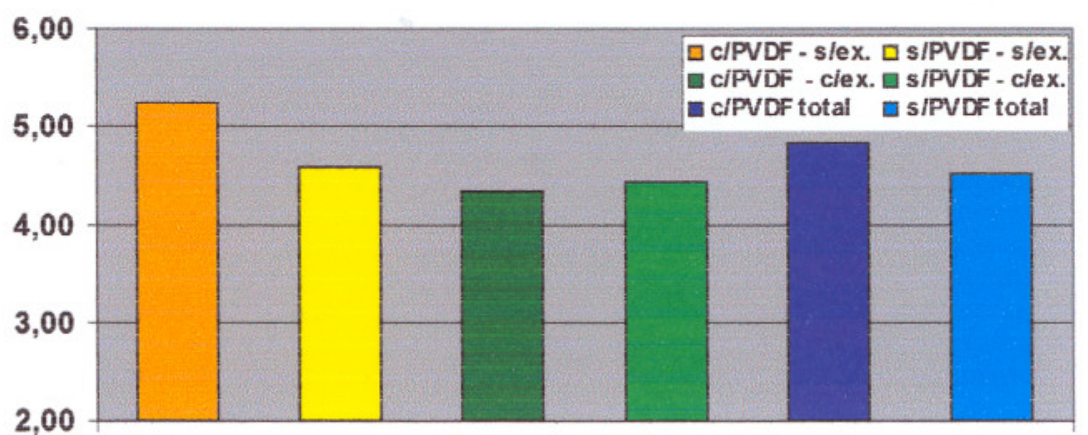

Média

Figura 19.14 - Gráfico dos valores médios para número trabecular. (c/PVDF-s/ex. - com PVDF, sem exercício); (s/PVDF-s/ex. - sem PVDF, sem exercício); ( $c / P V D F-c / e x$ - com PVDF, com exercício); (s/PVDF-c/ex. - sem PVDF, com exercício); (c/PVDF-total. - todos os dados com PVDF); (s/PVDF total. - todos os dados sem PVDF). 
Tabela 19.15 - Pianilha contendo valores mensurados e estatísticos de separação trabecuiar.

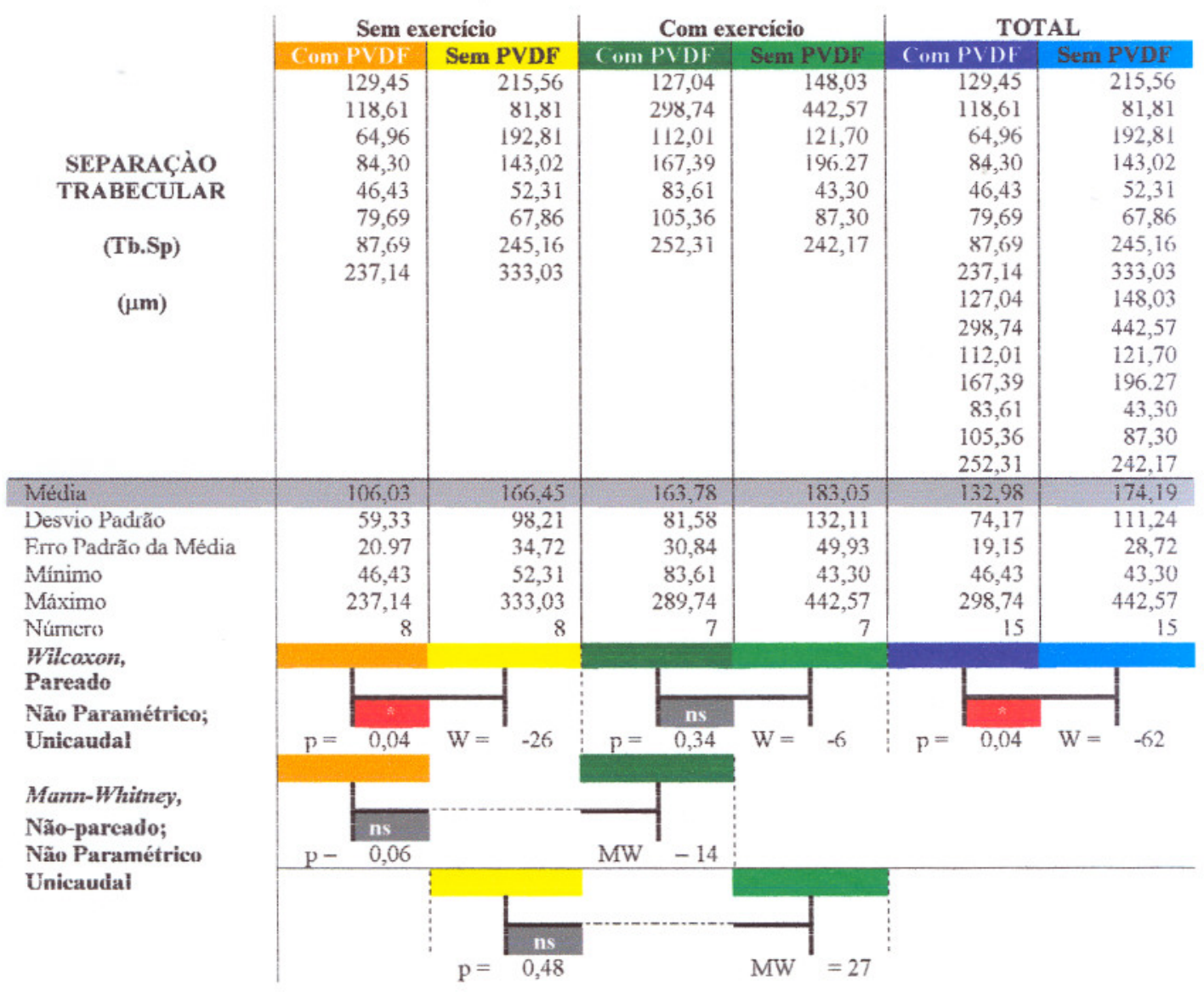

$(\mu \mathrm{m})$

Separação Trabecular (Tb.Sp)

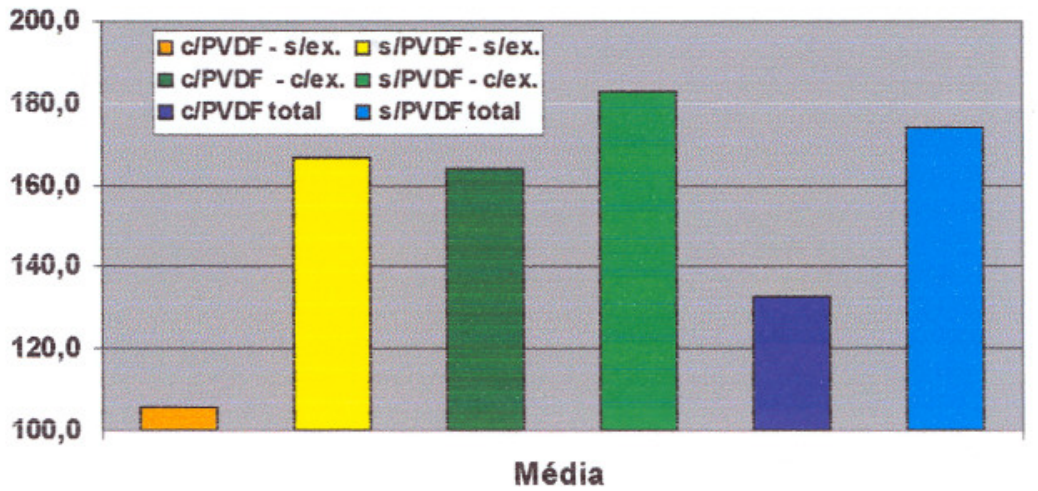

Figura 19.15 - Gráfico dos vaiores médios para separação trabecular. ( $C / P V D F-s / e x$ - com PVDF, sem exercício); (s/PVDF-s/ex. - sem PVDF, sem exercício); (c/PVDF-c/ex - com PVDF, com exercício); (s/PVDF-c/ex. - sem PVDF, com exercício); ( $/ P V D F$-total. - todos os dados com PVDF); (s/PVDF total. - todos os dados sem PVDF). 
Tabeia 19.16 - Planilha contendo valores mensurados e estatísticos de área de fibrose.

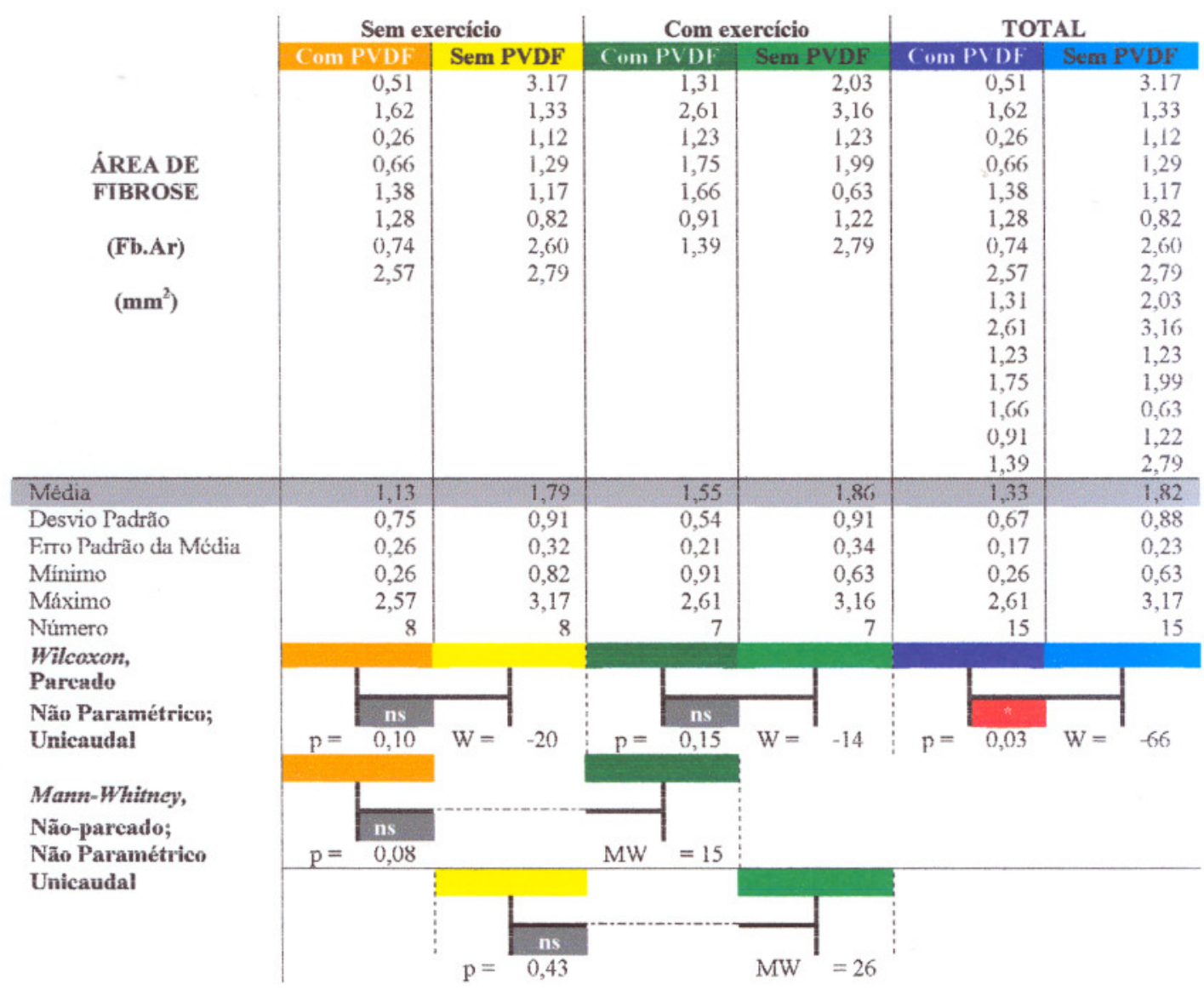

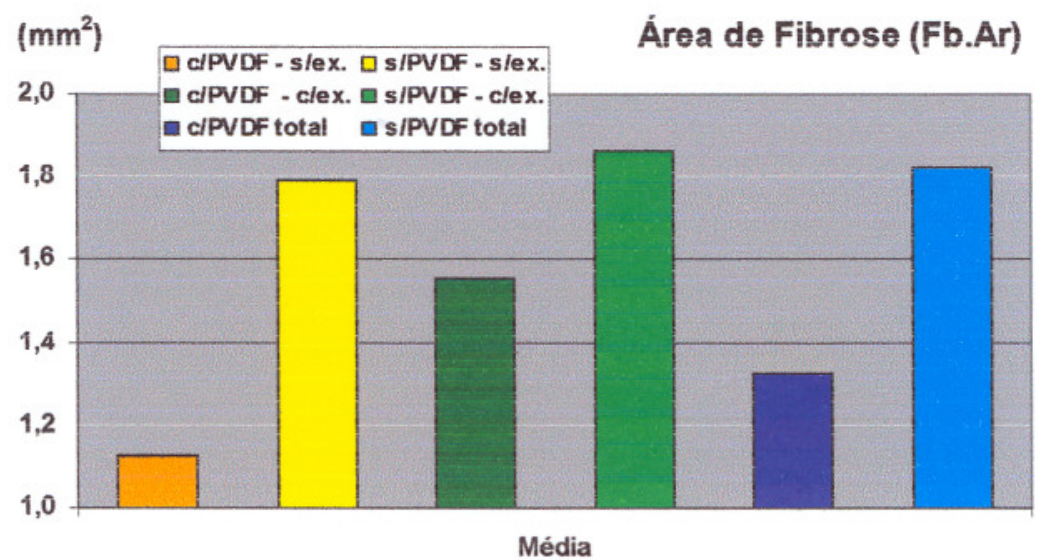

Figura 19.16 - Gráfico dos valores médios para área de fibrose. (c/PVDF-s/ex - com PVDF, sem exercício); (s/PVDF-s/ex. - sem PVDF, sem exercício); (c/PVDF-c/ex - com PVDF, com exercício); (s/PVDF-c/ex. - sem PVDF, com exercício); (c/PVDF-total. - todos os dados com PVDF); (s/PVDF total. - todos os dados sem PVDF). 
Tabeia 19.17 - Planilha contendo valores mensurados e estatísticos de volume de fibrose.

\begin{tabular}{|c|c|c|c|c|c|c|}
\hline & \multicolumn{2}{|c|}{ Sem exercício } & \multicolumn{2}{|c|}{ Com exercicio } & \multicolumn{2}{|c|}{ TOTAL } \\
\hline & Com PVDF & Sem PVDF & Com PVDF & Sem PVDF & Com PVDF & Sem PVDF \\
\hline & 9,00 & 39,84 & 25,59 & 39,72 & 9,00 & 39,84 \\
\hline & 28,65 & 26,08 & 41,70 & 46,25 & 28,65 & 26,08 \\
\hline & 3,88 & 16,50 & 19,75 & 19,74 & 3,88 & 16,50 \\
\hline \multirow{3}{*}{$\begin{array}{l}\text { VOLUME DE } \\
\text { FIBROSE }\end{array}$} & 12,83 & 19,00 & 23,78 & 31,76 & 12,83 & 19,00 \\
\hline & 20,30 & 17,19 & 32,60 & 12,29 & 20,30 & 17,19 \\
\hline & 18,76 & 16,15 & 17,91 & 23,86 & 18,76 & 16,15 \\
\hline \multirow[t]{2}{*}{ (Fb.V/TV) } & 14,50 & 51,01 & 27,24 & 54,71 & 14,50 & 51,01 \\
\hline & 50,40 & 32,78 & & & 50,40 & 32,78 \\
\hline \multirow[t]{7}{*}{$(\%)$} & & & & & 25,59 & 39,72 \\
\hline & & & & & 41,70 & 46,25 \\
\hline & & & & & 19,75 & 19,74 \\
\hline & & & & & 23,78 & 31,76 \\
\hline & & & & & 32,60 & 12,29 \\
\hline & & & & & 17,91 & 23,86 \\
\hline & & & & & 27,24 & 54,71 \\
\hline Média & 19,79 & 27,32 & 26,94 & 32,62 & 23,02 & 29,79 \\
\hline Desvio Padrão & 14,45 & 12,89 & 8,12 & 15,17 & 12,23 & 13,75 \\
\hline \multirow{2}{*}{$\begin{array}{l}\text { Frro Padrão da Média } \\
\text { Mínimo }\end{array}$} & 5,11 & 4,56 & 3,07 & 5,73 & 3,16 & 3,55 \\
\hline & 3,88 & 16,15 & 17,91 & 12,29 & 3,88 & 12,29 \\
\hline Máximo & 50,40 & 51,01 & 41,70 & 54,71 & 50,40 & 54,71 \\
\hline Número & 8 & 8 & 7 & 7 & 15 & 15 \\
\hline \multicolumn{7}{|l|}{$\begin{array}{l}\text { Wilcoxon, } \\
\text { Parcade }\end{array}$} \\
\hline Parcade & & & & & & \\
\hline \multirow{2}{*}{$\begin{array}{l}\text { Não Paramétrico; } \\
\text { Unicaudal }\end{array}$} & ns & & ns & & ns & \\
\hline & 0,23 & $\mathrm{~W}=$ & 0,15 & $\mathrm{~W}=$ & 0,07 & $\mathrm{~W}=$ \\
\hline \multicolumn{7}{|l|}{ Mann-Whitney, } \\
\hline \multirow{4}{*}{$\begin{array}{l}\text { Não-parcado; } \\
\text { Nãô Paramétrico } \\
\text { Unicaudal }\end{array}$} & ns & & & & & \\
\hline & 0,08 & & MW & & & \\
\hline & & & & & & \\
\hline & & $\begin{array}{c}\text { ns } \\
0,27\end{array}$ & & MW & & \\
\hline
\end{tabular}

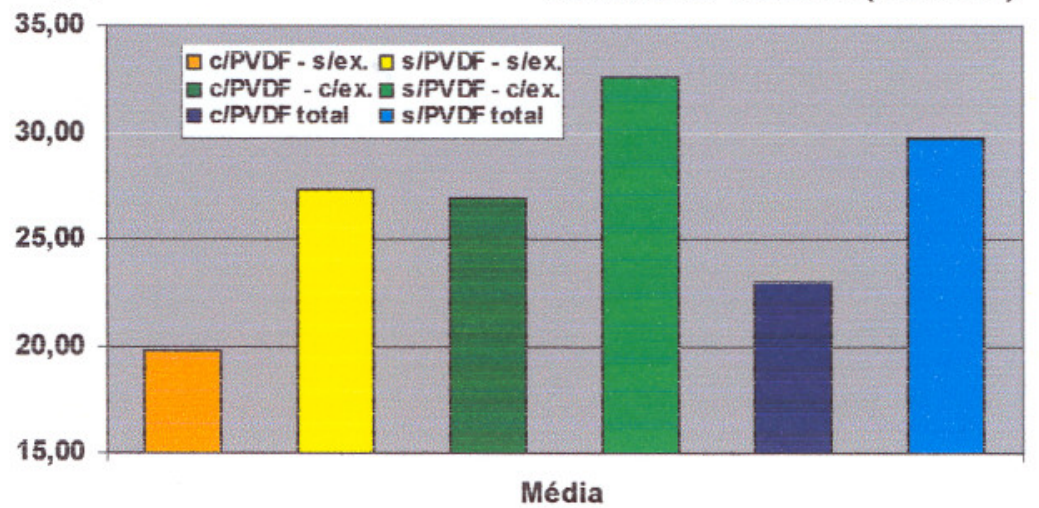

Figura 19.17 - Gráfico dos valores médios para volume de fibrose. ( $c / P V D F-s / e x$ - com PVDF, sem exercício); ( $s / P V D F-s / e x$ - sem PVDF, sem exercício); (c/PVDF-c/ex. - com PVDF, com exercício); (s/PVDF-c/ex. - sem PVDF, com exercício); (c/PVDF-total. - todos os dados com PVDF); (s/PVDF total. - todos os dados sem PVDF). 
Tabela 19.18 - Planilha contendo valores mensurados e estatísticos de perímetro de remodelamento.

\begin{tabular}{|c|c|c|c|c|c|c|}
\hline & \multicolumn{2}{|c|}{ Sem exercício } & \multicolumn{2}{|c|}{ Com exercício } & \multicolumn{2}{|c|}{ TOTAL } \\
\hline & Com PVDF & Sem PVDF & Com PVDF & Sem PVDF & Com PVDF & Sem PVDF \\
\hline \multirow{6}{*}{$\begin{array}{c}\text { PERIMETRO DE } \\
\text { REMODELAMENTO }\end{array}$} & 30,56 & 17,00 & 17,31 & 18,52 & 30,56 & 17,00 \\
\hline & 21,21 & 33,15 & 12,72 & 8,15 & 21,21 & 33,15 \\
\hline & 36,44 & 23,59 & 26,63 & 25,59 & 36,44 & 23,59 \\
\hline & 19,63 & 27,33 & 18,40 & 18,05 & 19,63 & 27,33 \\
\hline & 31,10 & 34,91 & 21,24 & 23,69 & 31,10 & 34,91 \\
\hline & 30,92 & 32,27 & 30,35 & 28,78 & 30,92 & 32,27 \\
\hline \multirow[t]{2}{*}{$(\mathbf{R m} \cdot \mathbf{P m}))$} & 38,97 & 22,05 & 15,53 & 9,29 & 38,97 & 22,05 \\
\hline & 13,94 & 30,70 & & & 13,94 & 30,70 \\
\hline \multirow[t]{6}{*}{$(\mathrm{mm})$} & & & & & 17,31 & 18,52 \\
\hline & & & & & 12,72 & 8,15 \\
\hline & & & & & 26,63 & 25,59 \\
\hline & & & & & 18,40 & 18,05 \\
\hline & & & & & 21,24 & 23,69 \\
\hline & & & & & 30,35 & 28,78 \\
\hline Média & & & & & 15,53 & 9,29 \\
\hline & 27,85 & 27,62 & 20,31 & 18,87 & 24,33 & 23,54 \\
\hline Desvio Padrão & 8,70 & 6,27 & 6,26 & 7,90 & 8,35 & 8,17 \\
\hline Frro Padrão da Mćdia & 3,08 & 2,22 & 2,36 & 2,98 & 2,16 & 2,11 \\
\hline Mínimo & 13,94 & 17,00 & 12,72 & 8,15 & 12,72 & 8,15 \\
\hline Máximo & 38,97 & 34,91 & 30,35 & 28,78 & 38,97 & 34,91 \\
\hline Número & 8 & 8 & 7 & 7 & 15 & 15 \\
\hline \multicolumn{7}{|l|}{$\begin{array}{l}\text { Wilcoxon, } \\
\text { Parcado }\end{array}$} \\
\hline & & & & & & \\
\hline \multirow{2}{*}{$\begin{array}{l}\text { Não Paramétrico; } \\
\text { Unicaudal }\end{array}$} & ns & & ns & & ns & \\
\hline & 0,47 & $\mathrm{~W}=$ & 0,19 & $\mathrm{~W}=$ & 0,40 & $\mathrm{~W}=$ \\
\hline \multicolumn{7}{|l|}{ Mann-Whitney, } \\
\hline \multirow{4}{*}{$\begin{array}{l}\text { Não-pareado; } \\
\text { Não Paramétrico } \\
\text { Unicaudal }\end{array}$} & $*$ & & & & & \\
\hline & 0,04 & & MW & & & \\
\hline & & & & & & \\
\hline & & 0,04 & & $\mathrm{MW}=12$ & & \\
\hline
\end{tabular}

(mm) Perímetro de Remodelamento (Rm.Pm)

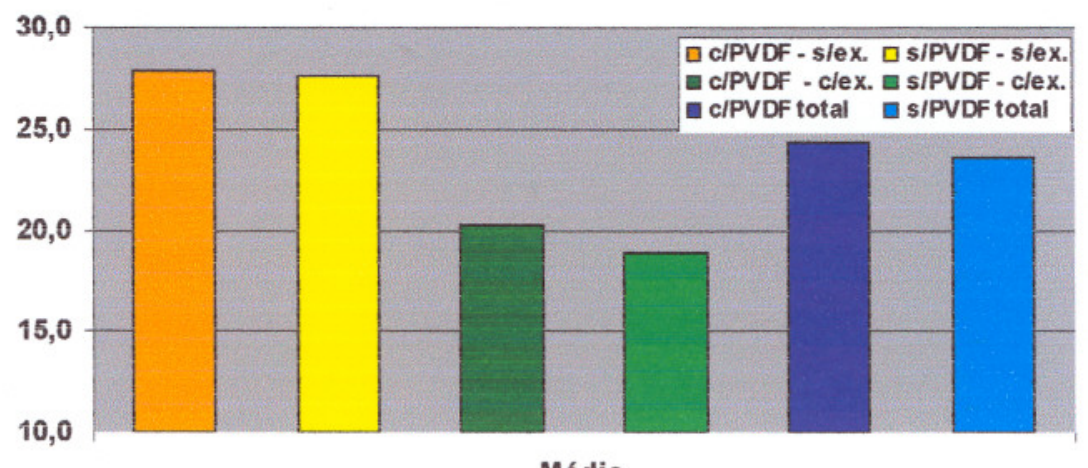

Figura 19.18 - Gráfico dos valores médios para perímetro de remodelamento. (c/PVDF-s/ex - com PVDF, sem exercício); (s/PVDF-s/ex - sem PVDF, sem exercício); (c/PVDF-c/ex. - com PVDF, com exercício); (s/PVDF-c/ex. - sem PVDF, com exercício); (c/PVDF-total. - todos os dados com PVDF); (s/PVDF total. - todos os dados sem PVDF). 